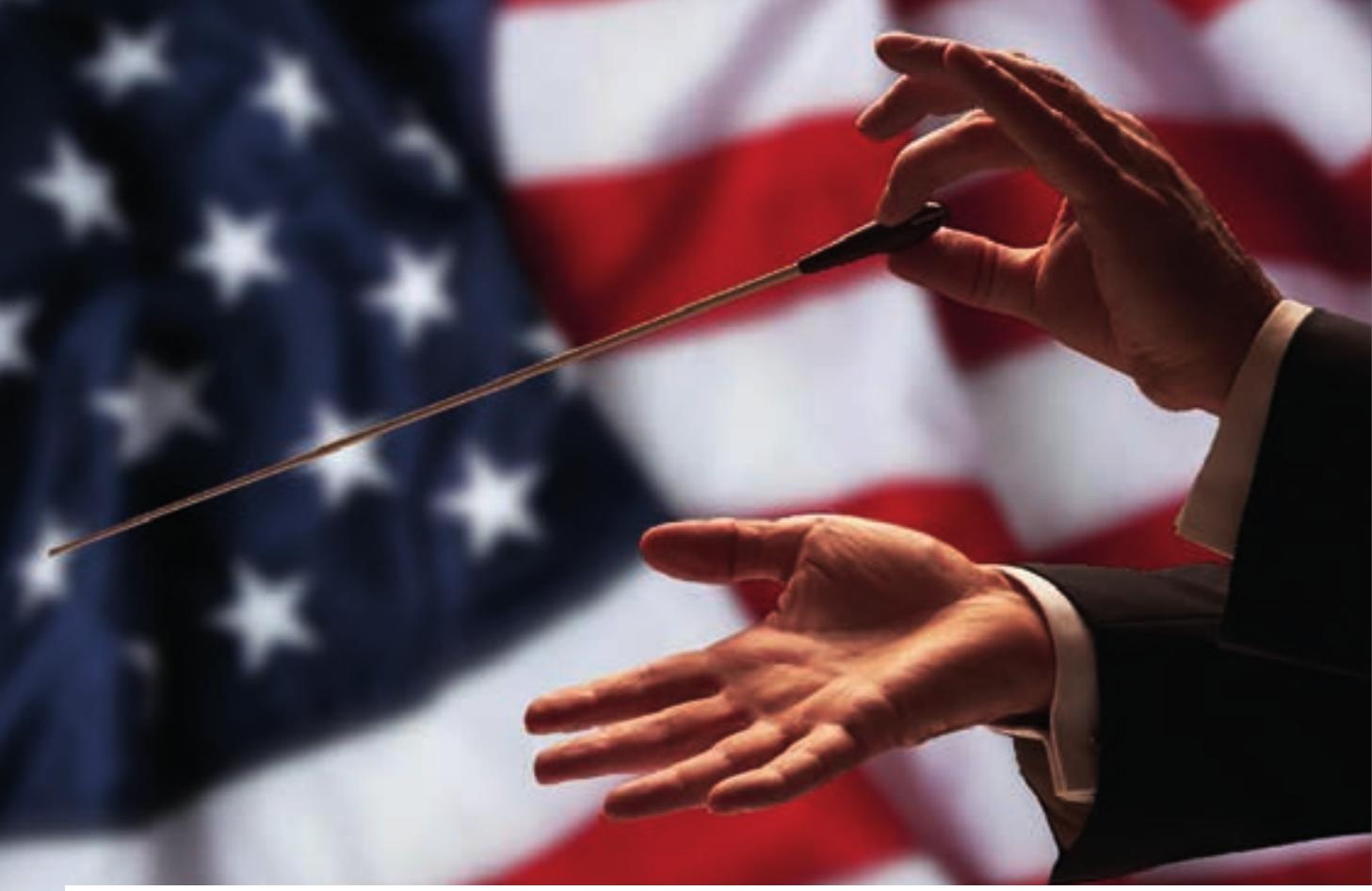

Paul Christiansen

\title{
Orchestrating Public Opinion
}

How Music Persuades in Television Political Ads for US Presidential Campaigns, 1952-2016 
Orchestrating Public Opinion 



\section{Orchestrating Public Opinion}

How Music Persuades in Television Political Ads for US Presidential Campaigns, 1952-2016

Paul Christiansen 
Cover design: Coördesign, Leiden

Lay-out: Crius Group, Hulshout

Amsterdam University Press English-language titles are distributed in the US and Canada by the University of Chicago Press.

$\begin{array}{ll}\text { ISBN } & 9789462981881 \\ \text { e-ISBN } & 9789048531677 \\ \text { DOI } & 10.5117 / 9789462981881 \\ \text { NUR } & 670\end{array}$

(c) P. Christiansen / Amsterdam University Press B.V., Amsterdam 2018

All rights reserved. Without limiting the rights under copyright reserved above, no part of this book may be reproduced, stored in or introduced into a retrieval system, or transmitted, in any form or by any means (electronic, mechanical, photocopying, recording or otherwise) without the written permission of both the copyright owner and the author of the book.

Every effort has been made to obtain permission to use all copyrighted illustrations reproduced in this book. Nonetheless, whosoever believes to have rights to this material is advised to contact the publisher. 


\section{Table of Contents}

$\begin{array}{ll}\text { Acknowledgments } & 7\end{array}$

$\begin{array}{lr}\text { Introduction } & 10\end{array}$

1. The Age of Innocence: $195^{2} \quad 31$

2. Still Liking Ike: 1956

3. The New Frontier: $1960 \quad 47$

4. Daisies for Peace: $1964 \quad 56$

5. This Time Vote Like Your Whole World Depended On It: $1968 \quad 63$

6. Nixon Now! 1972

7. A Leader, For a Change: $1976 \quad 90$

8. The Ayatollah Casts a Vote: $1980 \quad 95$

9. Morning in America: $1984 \quad 101$

10. Horton Hears a “Who?”: $1988 \quad 119$

11. It's the Economy, Stupid! $1992 \quad 129$

12. At Millennium's End: $1996 \quad 138$

13. Bush v. Gore: $2000 \quad 144$

14. Mourning in America: $2004 \quad 15^{1}$

15. Whatever It Takes: 2004, continued 166

16. Yes, We Can: $2008 \quad 175$

17. The $47 \%$ Solution: $2012 \quad 185$ 
18. \#DemExit: 2016

Conclusion

212

Appendix 1. Interview with Jim Cole

222

Appendix 2. Interview with Matthew Nicholl

241

Glossary of Selected Musical Terms

252

Bibliography

258

Index

267 


\section{Acknowledgments}

The list of people to thank for their contributions to this project seems to grow daily. To start, I would like to thank acquisitions editor Jeroen Sondervan, my first editor at Amsterdam University Press, for seeing promise in my proposal and offering me a contract. His flexibility in allowing me more time to finish the book - when the 2016 election was still very much up in the air-was greatly appreciated. Following Jeroen's decision to leave AUP, acquisitions editor Maryse Elliott took up the reins and has my gratitude for helping make the process of creating a cover image and assessing figures go smoothly, among her other valuable contributions. Thanks go likewise to editor Kristi Prins in gatekeeping and editor Nanko van Egmond for cover text. Head of desk editing and production Chantal Nicolaes has been absolutely heroic in her efforts to move the book across the finish line, and I am grateful for her patience with my seemingly unending barrage of questions. Copy editor Asaf Lahat is a paragon of the judicious editor; I cannot thank him enough for the astoundingly painstaking effort he put into this book, which is much better due to his involvement. The whole production team at AUP has been excellent.

The list of people responsible for the successful production of this book stretches beyond AUP; for her indexing superpowers, Joanne Sprott deserves special mention, and I would like to express my profound gratitude to the two anonymous readers of my manuscript for their careful attention to and thoughtful suggestions for my work.

I am grateful to Jura Avizienis for reading and commenting on several chapters of this book. Her sharp eye for detail and her frequent exhortations for me always to keep my audience in mind proved invaluable. Matthew Killmeier, with whom I collaborated on a journal article about the 2004 Bush ad "Wolves" and who contributed to my early thinking about music in political ads, deserves recognition for his insights as I began more seriously to think about this topic.

The American Musicological Society awarded me the 2015 Janet Levy Award, for which I am thankful; it allowed me a research trip to numerous presidential libraries. Archivists whom I met during my trip and who all offered valuable assistance are reference archivist Kevin M. Bailey and audiovisual archivist Kathy Struss at the Dwight D. Eisenhower Presidential Library, Museum, and Boyhood Home in Abilene, Kansas; digital archivist Liza Talbot at the Lyndon B. Johnson Presidential Library in Austin, Texas; archives technician Rachael C. Medders at the George Bush Presidential 
Library in College Station, Texas; and archives technician Alison Wheelock at the George W. Bush Presidential Library in Dallas, Texas. In addition, I would like to acknowledge those research specialists with whom I corresponded electronically: audiovisual archivist Laurie Austin at the John F. Kennedy Presidential Library and Museum; archivist Carla Braswell at the Richard Nixon Presidential Library and Museum; archives technician Brittany Gerke at the William J. Clinton Presidential Library; and archivist Jenny Mandel at the Ronald Reagan Presidential Library and Museum. I offer sincere thanks to all.

Derek Matravers earned my gratitude for his patience in explaining to me the philosophical arguments surrounding the arousal theory of music. I thank Mark Brill for giving me detailed insights for my introduction and offering additional valuable information for my discussion of Lyndon Johnson's ad "Poverty." Additionally, I would like to acknowledge Scott Harris, who offered his thoughts on music in two Dole ads from the 1996 campaign. Peter Martin has my thanks for his suggestions regarding my 2012 "Morning in America" paper, delivered at the Annual Meeting of the American $\mathrm{Mu}-$ sicological Society. Scholars of Russian music whom I consulted regarding Nixon's "Russia" include Olga Manulkina, Marina Frolova-Walker, Dmitri N. Smirnov, John Riley, Pauline Fairclough, Gerard McBurney, and Richard Taruskin; I thank them for their willingness to answer my inquiries. My interview subjects Jim Cole and Matthew Nicholl gave freely of their time, and I believe that their comments as practitioners in the field will contribute significantly to readers' understanding of this topic.

Work on this book has taken place over the course of a decade, and the research I did also found its way into my teaching. In this regard, I would like to thank the undergraduate and graduate students in my Music in Television Commercials seminars, given at the University of Southern Maine in 2006 and 2009. Their enthusiasm for the material was an inspiration, and their spirit infuses some of the ideas found herein.

Furthermore, I am deeply grateful to my valued colleagues and students at Seton Hall University for their support and encouragement. Specifically, I would like to thank the following people for facilitating a course release for me with which I was able to complete final revisions: Larry Robinson, Greg Burton, Deirdre Yates, Tom Rondinella, Christine Krus, Dena Levine, Dag Gabrielsen, Gloria Thurmond, and Jason Tramm. Courtney Starrett deserves acknowledgment for helping me assemble the elements that comprise the cover image. For the inspiration of their work in media studies and the stimulating conversations we had as I was finishing the book, I thank Jon Kraszewski and Chris Sharrett. For special appreciation I would 
like to mention Jordan Green, undergraduate student at Seton Hall, for his assistance in setting the music examples.

Sandy Wachholz has my heartfelt gratitude for her constancy as a friend during the entire time I wrote this book.

For his encouragement and confidence in me as well as the best piece of advice I ever received about writing a book, I am indebted to Michael Beckerman.

Finally, my wife Šárka deserves deep gratitude for her love, support, wisdom, and patience during the years I was researching and writing. I could not have written the book without her in my corner. My children Stefan and Sophia have been troopers and are owed some extra attention, which I am starting to give them as I (with relief) submit this manuscript. 


\section{Introduction}

Democratic candidate John Kerry was stunned when he realized that he would have to concede the US presidential election on November 3, 2004. Throughout the summer, his polling numbers had showed him leading Republican candidate George W. Bush. Several factors working against Bush-his failure to capture or kill Osama bin Laden, two protracted expensive wars, a sluggish economy-forced the Republican campaign into crisis mode. Although ad blitzes in battleground states had tightened the gap as Election Day approached, exit polls seemed to indicate Kerry's eventual victory.

Bush won, however, with a razor-thin $51 \%$ to $49 \%$ margin in Ohio, the deciding state in the Electoral College. Given such a modest victory, any single factor could have made the difference. ${ }^{1}$ Could political ads run in September and October by the Bush campaign and certain 527 organizations (tax-exempt political advocacy groups) have really made the difference in a photo-finish election? In the pages that follow, I hope to show this to be a distinct possibility.

An example should illustrate my point. The most powerful emotional appeal of the 2004 US presidential campaign, and perhaps one of the most effective TV political ads ever, was Bush-Cheney's "Wolves." In a campaign in which ads with music were ever-present, "Wolves" stood out. I will briefly discuss this ad here in order to describe its impact, though I return to it later in this study. The transcript of "Wolves" is as follows:

\section{NARRATOR VOICE-OVER}

In an increasingly dangerous world, even after the first terrorist attack on America,John Kerry and the liberals in Congress voted to slash America's intelligence operations by six billion dollars.

\footnotetext{
1 This argument leaves aside widespread allegations of misconduct and intentional voter suppression in the state (and elsewhere) during the 2004 election. For more information, see for example Steven F. Freeman, Joel Bleifuss, and John Conyers, Jr., Was the 2004 Presidential Election Stolen?: Exit Polls, Election Fraud, and the Official Count (New York: Seven Stories Press, 2006) and Mark Crispin Miller, Fooled Again: How the Right Stole the 2004 Election and Why They'll Steal the Next One Too (Unless We Stop Them) (New York: Basic, 2005).

2 The interpretation here is adapted from an article I wrote with Matthew Killmeier, "Wolves at the Door: Musical Persuasion in a 2004 Bush-Cheney Campaign Ad," MedieKultur:Journal of Media and Communication Research 50 (2011): 157-77.
} 


\section{WRITTEN TEXT}

Kerry and liberals in Congress: intelligence cuts $\$ 6$ billion, CQ Vote \#39, '94

\section{NARRATOR VOICE-OVER}

Cuts so deep they would have weakened America's defenses. And weakness attracts those who are waiting to do America harm.

BUSH DISCLAIMER

I'm George W. Bush and I approve this message.

The visual narrative of "Wolves" is of an unidentified subject (apparently the viewer), disoriented and frightened in a dark and foreboding forest, gradually realizing that a wolf is present. In the final scene, a pack of six wolves is revealed, just as they scatter in different directions. The metaphor of wolves as terrorists is unmistakable. Although the imagery and voice-over lend meaning to the ad, they are only handmaidens to the music, which conveys most of the emotional affect. And it is not just any music - it is music that one might find in a horror film: a low, rumbling drone, primal drums, shrill dissonance, uncanny timbres, and more. It grows increasingly dissonant until the final chord, which slides down in a nauseating way.

Music in the ad creates fear and panic, and it relies on the audience's participation for its effectiveness. It is thus the music, rather than any rational argument, that elicits fear from an unsuspecting audience. How does the music convey fear? The opening sequence presents a low $\mathrm{F}$ drone in a flutelike timbre, combined with an explosive, attention-getting drumbeat, followed by a softer drumbeat. Setting the tone for what is to follow, this music immediately evokes fear and unease. By the end, an F minor scale is constructed. Taken with the intense and hushed voice-over by a female narrator ${ }^{3}$ and the confusing, mysterious images of out-of-focus trees, connected by jump cuts with fleeting flashes of a wolf, the music chills the viewer to the bone.

It is only through music that we perceive the wolves as the collective threat that the advertisement's creators want us to perceive. Without a musical element, the ad would be simply a series of confusing images of the forest and of one wolf and subsequently six wolves, along with the voice-over, and it could strike audiences as absurd and nonsensical. Every 
other element of the ad hearkens to the music; pictures and words dance to the music's tune, not the other way around. So, far from mere innocuous accompaniment to the operational rhetorical argument, music is the lynchpin for the entire ad.

Music in "Wolves" is meant to be felt rather than heard-let alone analyzed. Electronically generated sounds distance the music from attempts at analysis, and the overall effect is surreptitious. In the ad proper, the last line is "And weakness attracts those who are waiting to do America harm." The climax at the word "waiting" brings the advertisement together, where the music is loudest and most suspenseful. "Waiting" is punctuated by a loud, dissonant chord followed by silence that primes the audience for the chilling four-word tagline: to do America harm. The narrator's ominous tone and the images of scattering wolves that ensue together create a powerful call to arms that we are compelled to heed. In Chapter 14, "Mourning in America," I discuss this ad in more detail, including its reference to popular mythology of the wolf.

"Wolves" was just one of many 2004 ads that trafficked in fear, but post-election surveys found "Wolves" to be one of the most effective and influential advertisements of the campaign. ${ }^{4}$ Of all the advertisements aired in battleground states, "Wolves" was the only one to have high, unaided recall, ${ }^{5}$ and it was also ranked the third-most influential advertisement in battleground states by Public Opinion Strategies. ${ }^{6}$ This ad made an indelible impact on voters in 2004. It is conceivable that political ad music alone could have tipped the balance in Bush's favor-music that we hear in "Wolves," and many other Bush ads that ran that year including "Swift Boat Veterans for Truth," "Whatever It Takes," and "Windsurfing." With so much music used in such clever and devious ways, it would seem counterintuitive to imagine that none of it affected viewers enough to make them vote one particular way. Attempts such as these to orchestrate public opinion with music in political ads are the subject of this book.

4 Lynda Lee Kaid, "Videostyle in the 2004 Presidential Advertising," in R.E. Denton Jr., ed., The 2004 Presidential Campaign (Lanham, MD: Rowman \& Littlefield, 2005), 296.

5 L. Patrick Devlin, "Contrasts in presidential campaign commercials of 2004," American Behavioral Scientist 49 (2005): 279-313 (287).

6 Jeffrey H. Birnbaum and Thomas B. Edsall, "At the end, pro-GOP 527 s outspent their counterparts," The Washington Post (November 6, 2004). Consulted on February 24, 2011, Proquest Newspapers database. 


\section{Orchestrating Public Opinion}

The title Orchestrating Public Opinion bears explanation. The Oxford English Dictionary defines "orchestrate" as follows:

1. To combine harmoniously, like instruments in an orchestra; to arrange or direct (now often surreptitiously) to produce a desired effect. Also with into.

2. To compose or arrange for an orchestra; to score for orchestral performance. ${ }^{7}$

The second, more literal definition is straightforward enough, but most important for this book is the first, figurative meaning, especially the clause following the semicolon: "to arrange or direct (now often surreptitiously) to produce a desired effect." Ad creators hope through their arranging and directing to produce a specific effect, and their means are often surreptitious.

Producers of political ads strive to generate strong emotional reactions in viewers, strong enough to impel them to action. Intentionality is crucial—even the tiniest gesture is planned to achieve maximum effect. These emotional appeals must be carefully calibrated, though, as ads perceived to be unjustly negative, offensive, or tasteless can backfire. Like a composer sketching themes for a symphony, ad creators begin by deciding on a few policy ideas that they want to emphasize (for example, universal health care together with the right to choose). ${ }^{8}$ Often, these ideas are presented in counterpoint to each other, developed, and recapitulated over the course of a campaign. In a well-conceived campaign - like that of President Reagan in 1984- the ads taken as a whole can seem carefully coordinated, like movements in a symphony. Campaign ads have a harmonious cumulative effect, each part contributing to the overall impact of several months of coordinated political efforts and targeted ad buys. In other words, they are orchestrated.

Finally, the conceit Orchestrating Public Opinion is meant to provoke and stimulate thought. ${ }^{9}$ Who is the actor of this participial phrase? It could be

7 "Orchestrate," v. Oxford English Dictionary, $3^{\text {rd }}$ edition (2004); online version June 2012. http://www.oed.com/view/Entry/132291. Accessed August 1, 2012.

8 Research has shown that campaigns that introduce too many issues into their agenda risk confusing voters (Darrell M. West, Air Wars: Television Advertising in Election Campaigns, 1952-2008. 5 th ed. [Washington, DC: CQ Press, 2010], 26).

9 The title also pays homage to Crystallizing Public Opinion (New York: Ig Publishing, 2011, reprint from 1923) by Edward L. Bernays, who also wrote Propaganda. Stuart Ewen, in his introduction to the book, writes, "For Bernays, 'crystallizing public opinion' was about taking 
a politician, campaign manager, an ad agency executive. In this metaphor, the "ad orchestrator" influences public opinion much as an orchestrator marshals the various sections of the orchestra, directing them to play to achieve a particular emotional effect such as sorrow or exultation. An orchestrator shapes music according to a predetermined design. This conceit further implies that people are being manipulated without their knowledge. Some might object to a characterization of the public as unwittingly influenced by emotional appeals contained in music, but the fact is that millions of campaign dollars are funneled into political ads because they work. I hope to show that they owe their effectiveness at least as much to music as to any other single element.

\section{Ringing "Pavlov's Bell”}

A 1984 article in the Wall Street Journal detailed how one corporation was turning to a nineteenth-century Russian scientist in order to sell more beverages through classical conditioning. Joel S. Dubow, in charge of communications research for Coca-Cola, said in the article, "We nominate Pavlov as the father of modern advertising." "Pavlov took a neutral object and, by associating it with a meaningful object, made it a symbol of something else; he imbued it with imagery, he gave it added value." ${ }^{10}$ Dubow's quote tells us how corporations and their advertising agencies view consumers. The Coca-Cola communications research manager unabashedly tells the world that his company is working hard to find out how to produce in consumers a mechanical reflex, rather than present a rational choice based on reasoned decision-making factors such as taste or nutrition. Of course, music is hardly a neutral element.

Not surprisingly, political campaigns aim to achieve the same result with their ads. They join positive images, music, and sounds to their candidates and negative ones with their opponents. They hope for mechanical and visceral reactions in the viewer. Political ads appeal to our most basic feelings - fear, pride, anger, greed. Most powerful can be a response generated in the amygdala, the area of the brain responsible for processing emotions and memory.

an 'ill-defined, mercurial and changeable group of individual judgments' and transforming them into a cohesive and manageable form," 3 . This is akin to what campaigns aim to do with their ads. 10 John Koten, “Coca-Cola Turns to Pavlov," Wall Street Journal (January 19, 1984), 34. Daniel Todes has pointed out that Pavlov never actually used a bell to make a dog salivate; see Daniel Todes, Ivan Pavlov: A Russian Life in Science (New York: Oxford University Press, 2014). I thank an anonymous AUP reviewer for suggesting this source to me. 
The amygdala receives signals directly from the auditory thalamus, and it is through the amygdala that music directly influences our emotions. Thus, ads whose music elicits fear achieve their effect without initially engaging the reasoning part of our brain, the cerebral cortex. Joseph LeDoux gives an example of how the cortex determines ex post facto whether we should react to a stimulus or not:

Imagine walking in the woods. A crackling sound occurs. It goes straight to the amygdala through the thalamic pathway. The sound also goes from the thalamus to the cortex, which recognizes the sound to be a dry twig that snapped under the weight of your boot, or that of a rattlesnake shaking its tail. But by the time the cortex has figured this out, the amygdala is already starting to defend against the snake. The information received from the thalamus is unfiltered and biased toward evoking responses. ${ }^{11}$

A fight-or-flight response is the kind of powerful reaction that campaigns seek to generate in negative ads. Campaign managers want to reach these fundamental impulses, side-stepping the reasoning process completely. In fact, it is not mere emotion that ads hope to stimulate, but rather emotions that impel us to action. After seeing a political ad exploiting fear, viewers want to move to safer ground, to protect themselves and those for whom they are responsible. To coin a pun, one could almost speak of a tele-kinetic aspect to such ads. Watching "Wolves" has this effect on a viewer.

Political ads generating fear form a category unto themselves. Political scientist Ted Brader's empirical research found music to be an effective element in campaign advertisements that appeal to fear. ${ }^{12}$ Fear appeals contributed to the likelihood of political novices withdrawing from political participation, while they inspired the politically initiated to act. Overall, "fear ads [elicit] the highest level of anxiety," and "menacing music and imagery [strengthen] reactions of fear and anxiety to the negative message. ${ }^{{ }_{13}}$ In a similar vein, Carol Krumhansl's experimental research found that subjects could identify fear within particular pieces of music. ${ }^{14}$ While listen-

11 Quoted in Jenefer Robinson, Deeper than Reason: Emotion and Its Role in Literature, Music, and Art (Oxford: Clarendon Press, 2005), 50.

12 Ted Brader, Campaigning for Hearts and Minds: How Emotional Appeals in Political Ads Work (Chicago: University of Chicago Press, 2006).

13 Brader, Campaigning for Hearts and Minds, 86.

14 Carol L. Krumhansl, "An Exploratory Study of Musical Emotions and Psychophysiology," Canadian Journal of Experimental Psychology $5^{1}$ (1997): 336-52. 
ing to excerpts identified as "fearful music," subjects experienced significant changes in pulse rate and heart rate variability. ${ }^{15}$

It might seem odd to discuss Pavlov in connection with political commercials. But if aural stimulus can condition viewers by repeated exposure to associate an opponent with negative aural stimuli, then it bears mention. A strong fight-or-flight response successfully connected to an opponent can be powerful. Once a negative aural association about an opponent takes root in a viewer's mind, that connection can be reinforced through prolonged exposure. ${ }^{16}$ What is wrong with using emotion in making political decisions? After all, recent research shows that emotion is crucial in making decisions. ${ }^{17}$ Another study, though, shows that we are incapable of using logical and empathetic/emotional ways of thinking simultaneously. That is, when we are attending to the emotional, we must abandon the rational. ${ }^{18}$

\section{Going Negative}

Ads generating fear are generally characterized as negative ads. They evoke primal emotions. Critiques of negativity in political advertising abound, but some scholars argue strongly in favor of negative political advertising —at least for their effectiveness, if not for any salubrious impact they might have

15 Additional explanation for how fear is processed in the brain can be found in Jenefer Robinson, Deeper than Reason: Emotion and Its Role in Literature, Music, and Art (Oxford: Clarendon Press, 2005), 47-52, and Laurel J. Trainor and Louis A. Schmidt, "Processing Emotions Induced by Music," in The Cognitive Neuroscience of Music, edited by Isabelle Peretz and Robert J. Zatorre (Oxford: Oxford University Press, 2003), 310-24.

16 And exposure is near constant in a tiny number of battleground states. Citing a post-election study by The Washington Post, Frank Bruni notes that over 50\% of the $\$ 896$ million spent on television advertising in the 2012 Obama-Romney matchup was spent in only three states: Virginia, Ohio, and Florida ("The Millions of Marginalized Americans," New York Times, July 25, 2015, http://www.nytimes.com/2015/07/26/opinion/sunday/frank-bruni-the-millions-ofmarginalized-americans.html). Accessed July 30, 2015.

17 Ben Seymour and Ray Dolan, "Emotion, Decision Making, and the Amygdala," Neuron $5^{8}$ (2008): 662-71. The first paragraph of their abstract lays out the conclusions of the study: "Clearly, there are several distinct mechanisms by which the amygdala plays a key role not just in simple conditioning but in complex decision making. Through Pavlovian learning, the amygdala can evoke conditioned responses that reflect an evolutionarily acquired action set capable of exerting a dominant effect on choice. Second, amygdala-based Pavlovian values are exploited by instrumental (habit-based and goal-directed) learning mechanisms in specific ways, through connectivity with other brain regions such as the striatum and prefrontal cortex." 18 "Empathy represses analytic thought, and vice versa: Brain physiology limits simultaneous use of both networks," press release from Case Western Reserve University, 30 October 2012, http://www.eurekalert.org/pub_releases/2012-10/cwru-era103012.php. Accessed March 18, 2015. 
on society, though some claim negative ads are good for democracy. Noting that negative attacks have always been part of politics in the US, political scientist John G. Geer, in arguing in favor of negative advertising, concludes that " $\mathrm{N}]$ egativity can advance and improve the prospects for democracy."19 In support of his thesis, Geer quotes Alex Castellanos, media consultant and campaign strategist for Republican campaigns, who avers that negative ads "inform people about the consequences of the wrong choices. ${ }^{20}$ Yet ads in which Castellanos had a hand did not so much inform as sensationalize and propagandize. For instance, "Wolves," which Castellanos produced, attacks with fear, presenting scarcely any rational evidence for its attack-fear is generated through horror music, sound effects, and jarring images. ${ }^{21}$

In the peroration of his introduction, Geer sums up arguments against negativity, arguments that he then belittles, claiming they show little faith in the public's ability to discern fact from fiction. ${ }^{22} \mathrm{He}$ has a point: negative ads so indeed focus attention and can offer more substantive arguments than their positive counterparts typically do. Yet even if we concede that negative ads typically present more factual evidence in support of their claims than positive ads, the standard remains low. Moreover, if negative ads tend to be more informative than positive ads, as Jamieson et al. and Geer contend, such ads are also sometimes misleading. (For example, Kerry's 1994 vote for "intelligence cuts," presented as evidence in "Wolves" for his disregard for homeland security, occurred seven years before the 9/11 attacks.) In essence, negative ads can be much worse than uninformative. But most importantly, by examining only rational appeals in negative or positive ads, we are missing the true thrust of political ads: appeal to emotion. Herein lies political ads' true power, and music unapologetically appeals to emotion.

In the literature review of their study "Eliminating the Negative? Categories of Analysis for Political Advertisements," Kathleen Hall Jamieson, Paul Waldman, and Susan Sherr deliver a withering critique of methodologies

19 John G. Geer, In Defense of Negativity: Attack Ads in Presidential Campaigns (Chicago: University of Chicago Press, 2006), 10.

20 Geer, In Defense of Negativity, 13.

21 Castellanos even resurrected a quote from the "Wolves" ad in an appearance on CNN during the Republican primary in March 2012 when he said about President Obama, "With this president there is doubt. [...] Politically there is doubt and weakness attracts [the] wolves" http://www.youtube.com/watch?v=Pqj_koCviMo. Castellanos was hoping to remind voters of negative feelings they had from the anti-Kerry ad from eight years earlier in an effort to present Obama in the same light.

22 Geer, In Defense of Negativity, 15. 
of earlier research on content analysis of political ads, followed by a passionate argument for their own unit analysis and ad weighting, and finally providing their own example of a contrast advertisement. ${ }^{23}$ In the same study, they claim that political ads are more informative than they are given credit for and that negative ads in particular give voters more information about issues than strict advocacy ads. ${ }^{24}$

It looks as though negative advertising is here to stay. Campaign advisers love "going negative," which they see as a powerful tool. Bill Clinton campaign adviser Mark Penn has said "Clever negative advertising works. That is reality. The tactic meets with media and pundit disapproval and spawns accusations of negativity, but the reality is that a clever negative ad can be devastatingly effective." ${ }^{25}$ Although ads become more expensive by the year, it seems that negative ones will always be with us. And in them, music continues to figure prominently.

\section{Tuning In}

The "sonorous envelope," to use Didier Anzieu's term, of a contemporary political ad is often highly symbolic and rife with rich and contradictory meanings. And when we combine the sound with image, we are left with a complicated objet d'art potentially of historical, social, and cultural significance. As Cynthia B. Meyers remarks, "Advertising, driven by the profit motive, also produces cultural meanings and cultural artifacts; while its economic imperative may be its structuring force, effective advertising must articulate contemporary cultural tensions in order to communicate with audiences. ${ }^{26}$

Just as Meyers notes that advertising produces cultural artifacts, Ron Rodman reminds us that television music taps into a sort of collective

23 Kathleen Jamieson, Paul Waldman, and Susan Sherr, "Eliminating the Negative? Categories of Analysis for Political Advertisements," in James A. Thurber, Candice J. Nelson, and David Dulio, Crowded Airwaves: Campaign Advertising in Elections (Washington: Brookings Institution Press, 2000), 44-64. Geer echoes this sentiment.

24 Thurber et al., Crowded Airwaves, 57.

25 Cited in Politico.com (August 11, 2008), as quoted in Travis N. Ridout and Michael M. Franz, The Persuasive Power of Campaign Advertising (Philadelphia: Temple University Press, 2011), 3 . 26 Cynthia B. Meyers, "From Sponsorship to Spots: Advertising and the Development of Electronic Media," in Media Industries: History, Theory, and Method, ed. Jennifer Holt and Alisa Perren (Malden, MA: Wiley-Blackwell, 2009), 70. 
subconscious of cultural tropes in order to work its magic. ${ }^{27}$ Originality is not the point - in fact, truly original music might defeat its purpose. Music in TV shows and ads must hew to viewers' cumulative knowledge and awareness. George Bush's 2004 "Windsurfing” ad, for instance, used Johann Strauss's Blue Danube waltz to devastating effect by inviting audiences to associate the piece's musical call-and-response structure with images of John Kerry windsurfing juxtaposed against their mirror images. In tandem with the flipped images, the music made Kerry a clear flip-flopper. ("Windsurfing" will be analyzed in Chapter 14.)

According to a recent study's finding that the Dunning Kruger Effect can help describe, people tend to think of others as more susceptible to harm from political attack ads than themselves. ${ }^{28}$ In a fallacy known commonly as the "third-person effect," people typically impute naïveté with regard to advertising to others, while imagining that they themselves are immune to such persuasion. ${ }^{29}$ In his book Seducing America: How Television Charms the Modern Voter, Roderick P. Hart observes that people experience politics emotionally rather than rationally; TV really does charm and seduce, rather than inform or educate.$^{30}$ Such an assertion seems so self-evident as to hardly need stating. Yet the ability of political ads to short-circuit logical thought is often underestimated. For example, a poor working-class voter might vote against his family's economic interest in electing a candidate from the party that says that it opposes same-sex marriage, even though this issue does not directly affect him, or he may favor the party that opposes restrictions on firearms that he cannot afford to purchase anyway. Ads can be effective in persuading viewers to vote even against their own political interests.

Hart posits that American TV viewers fancy themselves politically savvy, when in reality most are woefully uninformed or misinformed.$^{31}$ He cites studies that indicate that TV messages do not inform viewers much. ${ }^{2}$ In one study, people who claimed that they paid close attention to Senate campaigns were at a loss when asked to state candidates' issue

27 Ronald W. Rodman, Tuning In: American Narrative Television Music (Oxford: Oxford University Press, 2010), 14-15.

28 Ran Wei and Ven-Hwei Lo, "The Third-Person Effects of Political Attack Ads in the 2004 U.S. Presidential Election," Media Psychology 9/2 (2007): 367-88.

29 West, Air Wars, 17.

30 Roderick P. Hart, Seducing America: How Television Charms the Modern Voter, revised edition

(Thousand Oaks, CA: Sage, 1999).

31 Hart, Seducing America, 12-13.

32 Hart, Seducing America, 55-56. 
stands. ${ }^{33}$ Two other studies indicated that viewers shown dramatic news segments focusing on concrete examples could not induce the general from the specific. ${ }^{34}$ Thus, American TV viewers' ill-placed confidence in their imperviousness primes them to be influenced by political ads, including ads' least understood element, music.

\section{Music's Ineffability}

Why are music's effects so difficult to understand? For one thing, it would be difficult to determine exactly what assertion or accusation is being made. Music uses a semiotic system that operates on a plane distinct from verbal language. A candidate can hardly criticize an opponent for using music that shows the candidate in an unflattering light. There is no "argument" to rebut. If an ad's narrator asserts that the opponent voted two years ago to cut defense spending by five percent or that her husband's chairmanship of the board of a company whose fate is being decided by Congress is a clear conflict of interest, those claims are easily verified or disproven. But if an ad uses, say, circus music in conjunction with silly pictures of the opponent to make her look like a buffoon, how can the candidate counter? There are no "truth-in-advertising" dictates for music used in television commercials or political ads. Music deftly sidesteps attempts to assess its effects in rhetorical terms.

Regulating political ads to insure that claims are truthful and fair would be considered by many a violation of freedom of speech protections under the US Constitution. But rhetorical appeals can at least be parsed for content. Arguments can be identified and we can determine whether they are supported by evidence or not. Music, on the other hand, does not play by the same rules and does not offer up its secrets to traditional rhetorical analysis. What exactly does a deceptive cadence mean in the context of a political ad? Or a Picardy third? Or a bass clarinet ostinato? What do these things mean in connection with the images and voice-over? And how can a candidate argue against any of it?

33 Steven A. Peterson, Political Behavior: Patterns in Everyday Life (Newbury Park, CA: Sage, 1990), 230.

34 Shanto Iyengar and Donald R. Kinder, News that Matters: Television and American Public Opinion (Chicago: University of Chicago Press, 1987), 42, and Michael A. Milburn and Anne B. McGrail, "The Dramatic Presentation of News and its Effects on Cognitive Complexity," paper presented at the annual convention of the American Political Science Association, San Francisco, CA, August 1990, both references as cited in Hart, Seducing America, 55-56. 
It is not as though music has little to say, though — on the contrary. To quote German Romantic composer Felix Mendelssohn:

There is so much talk about music, and yet so little is said. For my part, I believe that words do not suffice for such a purpose, and if I found they did suffice I would finally have nothing more to do with music. People often complain that music is too ambiguous, that what they should be thinking as they hear it is unclear, whereas everyone understands words. With me it is exactly the reverse, and not only with regard to an entire speech but also with individual words. These, too, seem to me so ambiguous, so vague, so easily misunderstood in comparison to genuine music, which fills the soul with a thousand things better than words. The thoughts that are expressed to me by music that I love are not too indefinite to be put into words, but on the contrary, too definite. ${ }^{35}$

Mendelssohn tidily sums up music's ineffability, its outsider status in the realm of language - or rather, its insider status in the realm of emotion. Expressing in words music's impact — let alone articulating precisely how candidates can bolster their own candidacies or lay siege to their opponents through means that many people see only as an art associated with pleasure-is a precarious enterprise at best. Yet it is only with imperfect language that we can try to tease out how music can shape political outcomes through emotional appeal.

\section{Persuading Voters}

Television ads tend to be more effective when run just before an election. A recent study of voter preferences for a gubernatorial election in 2006 indicates that television political ads have brief but powerful effects on choice of candidate..$^{36}$ Whether ads actually significantly increase voter turnout is an open question, ${ }^{37}$ but they do appear to be effective in convinc-

35 Felix Mendelssohn, from a letter of 15 October 1842 to Marc-Andre Souchay, in Josiah Fisk, ed., Composers on Music: Eight Centuries of Writings, $2^{\text {nd }}$ ed. (Boston: Northeastern University Press, 1997), 84 .

36 Alan S. Gerber, James Gimpel, Donald P. Green, and Daron R. Shaw, "How Large and Longlasting Are the Persuasive Effects of Televised Campaign Ads? Results from a Randomized Field Experiment," American Political Science Review 105/1 (2011): 135-50.

37 Jonathan Krasno and Donald Green, "Do Televised Presidential Ads Increase Voter Turnout? Evidence from a Natural Experiment," Journal of Politics 70/1 (2008). 
ing undecided and unaffiliated voters - one study by Donald P. Green and Alan S. Gerber suggests that targeted ad buys can increase voter turnout in statistically significant ways. ${ }^{38}$ Other scholars demur. Travis N. Ridout and Michael M. Franz, among others, argue generally for a very modest effect of political advertising on voter preferences and turnout. Yet they concede, "Overall, television ads can influence voting choice and evaluations of candidates," continuing, "But because the effects are most often and most strongly felt in close races in which marginal effects can often change the dynamics of a race, it is likely true that the aggregate impact of ad exposure is central to the distribution of election outcomes. Put simply, in a political environment in which outcomes turn on a few thousand or even hundreds of votes, advertising may make the difference between winning and losing." ${ }^{39}$ Since the electorate in the US is so evenly divided, independent, undecided, and low-involvement voters can hand an election to George W. Bush or Barack Obama. This seems to be the situation for at least the near future. Thus we are interested in the potential of music in political ads to influence these swing voters.

Ridout and Franz, in focusing on overt arguments, miss the mark. Even their language assumes that ads persuade through informative rational appeals: "All told, though, seeing a high quantity of political ads gave voters additional information with which to evaluate the two candidates. ${ }^{140}$ Providing information is not the primary function of ads and evaluating is most certainly not what campaign managers would have voters do, evaluation implying a disinterested, dispassionate assessment of a candidate's record and policies. The authors too confidently attribute the result to voters' analyses and careful consideration of records and claims, rather than to emotional reactions to irrational appeals made by nonverbal means.

Just as they assert that TV ads are still the primary way in which politicians reach out to voters, ${ }^{41}$ Ridout and Franz do not recognize a causal problem in televised political advertising: "We simply believe that ads are less harmful to the electoral process than the conventional wisdom would suggest. Whatever ails American politics, we are convinced that television ads are not the cause. ${ }^{142}$ The reader will by now have intuited

38 Donald P. Green and Alan S. Gerber, Get Out the Vote: How to Increase Voter Turnout, $2^{\text {nd }}$ ed. (Washington, DC: Brookings Institution, 2008), 131-33.

39 Travis N. Ridout and Michael M. Franz, The Persuasive Power of Campaign Advertising (Philadelphia: Temple University Press, 2011), 71-73 [my emphasis].

40 Ridout and Franz, The Persuasive Power of Campaign Advertising, 57 [my emphasis].

41 Ridout and Franz, The Persuasive Power of Campaign Advertising, 7.

42 Ridout and Franz, The Persuasive Power of Campaign Advertising, 16. 
my qualified disagreement with this broad claim. Scholarship about nonverbal emotional appeals in ads is still in its nascent stage, so there is much that we just do not know. ${ }^{43}$ This study is an attempt to address that deficit.

\section{Previous Scholarship on Political Ads}

Music in ads has evolved over the course of sixty years that political ads have been aired on TV. In the early years of television political advertising, music, where it appeared, was a novelty, a mere accompaniment to the actors or voice-overs. In fact, entire campaigns ran TV ads with little or no music (Adlai Stevenson in 1956, Richard Nixon in 196o, George McGovern in 1972, John Anderson in 1980). Political campaigns and the media companies that have created for them have grown more sophisticated in their use of music as they have gradually understood music's power to surreptitiously persuade. Thus the center of gravity in this book is firmly in the second half of the TV political ad's chronology.

Scholars writing about political advertisements almost invariably privilege images and language above music. When music is mentioned at all, it is in an off-hand way, in subordination to analyses of rhetorical arguments and discussions of text and images. Reading these studies, one gets the impression that music in an ad is something of an afterthought, an innocuous accompaniment to visual and textual elements. In this book I take an oposing view, arguing that music is a key element in an ad's construction. In some cases, it can even be determinative: that is, all other elements in an ad-images, voice-over, sound effects, written text, and so on - can be circumscribed by the music and interpreted in relation to it.

No systematic study exists, or even any significant literature from political science, mass communication, or related fields treating music in political ads. ${ }^{44}$ One might expect this lacuna to be at least partly addressed by Roderick Hart's book Seducing America: How Television Charms the Modern

43 Criticism of political advertising is not limited to the scholarly sphere, nor is it only done in all seriousness. The fourth season episode from the Mr. Show with Bob and David entitled "McHutchence vs Greeley III" is an incisive commentary on contemporary political ads. Striking is the sketch's accurate portrayal of how political ads present candidates and their opponents. The smarmy grins, the family gathered around, even the music is spot on. In fact, the music resembles real political ad music in virtually every particular.

44 Benjamin S. Schoening and Eric T. Kasper do devote three chapters of their recent book to TV political advertising (Benjamin S. Schoening and Eric T. Kasper, Don't Stop Thinking About the 
Voter. After all, music in political ads can do many things, but nothing if not seduce and charm. Yet throughout the book music receives virtually no discussion, and the word "music" (along with variations on the word) is conspicuously absent from the book's index. ${ }^{45}$ In a comprehensive history of US political ads on television from $195^{2}$ to 2008, numbering 240 pages, "music and sounds" (as we find music listed in the index) receive roughly one half a page of treatment. ${ }^{46}$ Even Campaigning for Hearts and Minds: How Emotional Appeals in Political Ads Work, Ted Brader's compelling and overdue corrective to the scholarly neglect of emotional appeals in political ads, addresses music only obliquely. Such pretermissions vividly illustrate a general lack of interest - or perhaps awareness - among political scientists, sociologists, and communication scholars in music's role in political ads.

\section{How Music Functions in Ads}

Perhaps not surprisingly, attempts to rectify this state of affairs have come chiefly from musicologists. Some preliminary and tentative studies have recently been conducted on the role of music in advertising. A recent foray into this area is Nicolai J. Graakjær's 2011 article on musical meaning in television commercials, as exemplified in a spot for Riberhus cheese. In the article, Graakjær describes the complexities and potential problems of using pre-existing music to advertise products, and he points out the strong need for more research into the use of music in television advertising. ${ }^{47}$ In 1989 David Huron suggested that music can be used to target certain demographic, psychographic, and political groups, tapping already established articulations between musical genres, styles, and social collectives. ${ }^{48}$ Similarly, it can facilitate the establishment of authority, the determination of a character's ethos. Here music is used as "a very effective nonverbal identifier" that connects the target audience with the appropriate group

Music: The Politics of Songs and Musicians in Presidential Campaigns [Lanham, MD: Lexington, 2012]).

45 Roderick P. Hart, Seducing America:How Television Charms the Modern Voter, revised edition (Thousand Oaks, CA: Sage, 1999).

46 West, Air Wars.

47 Nicolai J. Graakjær, (2006). "Musical Meaning in TV-commercials: A Case of Cheesy Music," Popular Musicology Online, 5 (2006), http://www.popular-musicology-online.com/issues/05/ nicolai-01.html. Accessed March 182015.

48 David Huron, "Music in Advertising: An Analytic Paradigm," Musical Quarterly 73 (1989): 557-574. 
(i.e., race, sex, age, and socioeconomic class/status). ${ }^{49}$ Melodies, timbres, rhythms, and so forth target audiences through an established network of historical connotations..$^{50}$

In his 2001 book Analysing Musical Multimedia, Nicholas Cook claims that music ascribes attributes to products, but that it is also affected by other signifiers (verbal, aural, and visual).51 "If the music gives meaning to the images, then equally the images give meaning to the music., ${ }^{52}$ Working on a "subverbal, almost subliminal" level, music helps to connect a product with signification from outside and can make absurd arguments seem plausible. ${ }^{53}$ We will see evidence of this claim later in this book.

Virtually all studies of music in political ads, even recent ones, address music at merely a rudimentary level. In one instance, journalism scholars Glenn Hubbard and Elizabeth Crawford conducted an experimental study where subjects self-identified as Republicans or Democrats were asked their opinions about radio ads with music and without music. ${ }^{54}$ The authors applied the Elaboration Likelihood Model of persuasion, concluding that music in political ads does not "translate into a statistically significant preference for the candidate." In a section of their article entitled "Limitations," Hubbard and Crawford admit two limitations of the study that affected sample size and composition. But the authors neglected to admit their greatest limitation: they do not engage the music at all from a theoretical or analytical perspective. As a result, the authors apply an inappropriate binary quantification to music in political ads_- "has music" or "lacks music" —as if all genres and styles of music had the same effect on listeners. In order to assess the validity of their claims, one would need at a minimum to know the general character of the music, whether it is congruent or incongruent with the images and voice-over, and so on. Yet the authors never elaborate on the music used to test their hypotheses more than to say "background music" or "instrumental music." They are not alone. Scholars from fields such as journalism, political science, or media studies often make sweeping pronouncements about music's effectiveness in persuasion without the requisite skills or knowledge, thus distorting our understanding of music's

Huron, "Music in Advertising," 568.

Huron, "Music in Advertising," 571.

51 Nicholas Cook, Analysing Musical Multimedia (Oxford: Oxford University Press, 2001).

$5^{2}$ Cook, Analysing Musical Multimedia, 8.

53 Cook, Analysing Musical Multimedia, 20.

54 Glenn T. Hubbard and Elizabeth Crisp Crawford, "Music in Political Advertisements: Music to the Ears or Background Noise? A Study of Music's Influence on Message Relevant Thinking," Journal of Radio and Audio Media (2008): 164-81. 
role in persuasion. Much of the most up-to-date scholarship on music in political ads is woefully lacking in musico-theoretical sophistication.

In a recent book, two scholars posit a decreasingly important role for music in television political advertisements. Since theirs is the only book that discusses music in television political ads in any detail, their assertions deserve some scrutiny here. Benjamin S. Schoening and Eric T. Kasper, authors of Don't Stop Thinking About the Music: The Politics of Songs and Musicians in Presidential Campaigns, write: "Later campaigns would take a route similar to Nixon's advertisements of 1968 , relegating music on television advertisements to the background." ${ }^{55}$ Actually, this claim is not supported by the facts. It is not that music receded into the background; rather, campaigns only gradually came to learn how to harness its power as a surreptitious agent. In fact, Nixon's 1968 ads broke new ground with regard to using music effectively in political advertisements. There is nothing "background" about music in "First Civil Right" or "Convention"—on the contrary, these ads set a new standard for dissonant music and disturbing imagery in negative political advertising. While it is true that music was used only in limited ways in ads for the 1972,1976 , and 1980 elections, this is only because it took time before campaigns began to realize the full potential for emotional manipulation of voters through music. Starting in 1984 , we see ads where music is not only an important element of an ad, it is the crucial element, the central appeal.

Even the title of an entire chapter section of Don't Stop Thinking About the Music misstates the case: "Music Recedes on the Campaign Trail and in the Television Ad. ${ }^{n 6}$ In this chapter section, Schoening and Kasper dismiss "Nixon Now," which from a musical point of view brilliantly tapped into the current commercial campaign of Coca-Cola, as "a rather cheesy rendition of a song." ${ }^{57}$ Similarly, they downplay the music in "McGovern Defense," because it consisted of a lone snare drum..$^{58}$ Not only is this assertion false ("Hail to the Chief" is played toward the end of the ad), it also underestimates the power of the single snare playing military cadences while the narrator attacks McGovern's record on defense spending.

Even ads that completely transformed the landscape of political advertising in television, such as Reagan's "Morning in America” and Bush's “Wolves"

55 Benjamin S. Schoening and Eric T. Kasper, Don't Stop Thinking About the Music: The Politics of Songs and Musicians in Presidential Campaigns (Lanham, MD: Lexington, 2011), 135 [my emphasis].

$5_{6}$ Schoening and Kasper, Don't Stop Thinking About the Music, 134-137.

57 Schoening and Kasper, Don't Stop Thinking About the Music, 135 .

58 Ibid. 
receive only grudging acknowledgment by Schoening and Kasper: "All of these 1984 and 2004 examples involve music staying somewhat relevant on television, but also music that is no longer the most important part of the ad." ${ }^{59}$ Later in the same paragraph, they assert, "The music continues to serve as an important function [sic] in this form of communication, but not nearly as important on television as was the case when commercials played full campaign songs without a voice-over coming in and cutting away from the music." ${ }^{60}$ Such a position can only be embraced when one disregards how music actually works in ads. Most often, the music that calls the least attention to itself is the most powerful. Jingles and campaign songs of the 1950s, for instance, while often catchy and easily memorable, do not have the immediate and inescapable impact of the underscoring of the patriotic paean "Morning in America" or the horror-film-inspired "Wolves."

For too long, music's role in political persuasion - seemingly well understood by campaign professionals - has remained largely terra incognita, underexplored and misunderstood in the scholarly sphere and public square. With this volume, I examine numerous ads since the advent of the television political ad in $195^{2}$ up to the present day, employing musical analysis as well as textual and rhetorical analysis to illuminate music's often hidden methods of persuasion. I will argue that 1968, 1984, and 2004 mark the most important milestones in the history of music in political ads. Several of Richard Nixon's 1968 campaign ads use music in inventive ways for negative ads. The series of "feel good" positive ads in 1984 for Ronald Reagan, with "Morning in America" at its center, used music for the first time cinematically. ${ }^{61}$ Drawing on American hysteria following the September 11 Al Qaeda attacks, George W. Bush's 2004 campaign used music inspired by horror film soundtracks in devastatingly effective ways to argue that John Kerry was unable to address the threat of terrorism. So "Wolves" opens the cinematic scope started by "Morning in America" to include the horror genre. ${ }^{62}$ Each of these watersheds influenced political ad music to follow.

Chapters that follow discuss significant ads year by year. Nine case studies treat ads of particular interest for their music: "Ike for President"

59 Schoening and Kasper, Don't Stop Thinking About the Music, 136.

60 Ibid.

61 Walter Benjamin wrote of fascists aestheticizing politics (Walter Benjamin, "The Work of Art in the Age of Mechanical Reproduction," in Literary Theory: An Anthology, eds. Julie Rifkin and Michael Ryan [Oxford: Blackwell, 1998], 282-89), and "Morning in America" might seem an example par excellence of this process.

62 In the 1980 s chapter I will argue that horror film music was actually first used in Mondale ads in 1984 , but to much more limited effect. 
(1952), "Kennedy-Jingle" (1960), "Mother and Child" (1968), "Nixon Now" (1972), "Morning in America” (1984), "Revolving Door" (1988), "Wolves" (2004), "Firms" (2012), and "America" (2016). With hundreds of ads to choose from, selecting representative ads posed a serious challenge. Some might dispute the selections I have made, and I accept that criticism. My hope is that shorter discussions of important ads in the decade chapters, combined with in-depth examinations of the case studies, will give the reader a fair representation of the myriad ways in which music has been and continues to be used in presidential campaigns. Later chapters include discussion of web ads, which have become an increasingly important political phenomenon. Finally, a Conclusion assesses the effects of music in ads on the democratic process and offers possible solutions and suggestions for new avenues of research. Rounding out the book are a glossary of musical terms and two appendices - interviews with practitioners who describe their experiences with writing music for political ads.

I make no claim to comprehensive coverage of six decades of presidential ads, and this book also limits itself to ads from general elections, ignoring primaries. With few exceptions, I have selected only ads lasting one minute or less. Longer ads, usually running about four minutes, are sui generis; they are typically biographical in nature. Only a couple are treated here as I have chosen to focus on the more typical thirty- and sixty-second ads. For the most part, chosen ads are accessible on the Living Room Candidate website of the Museum of the Moving Image (www.livingroomcandidate. org) so that readers may view them in order to follow my arguments. Music examples, tables, and stills from selected ads will help explain how political ads influence us.

This book presents my own point of view, which draws primarily on musicology and music analysis. Experimental psychologists would approach the phenomenon of political ad music from a different angle. Nevertheless, there is little in the way of hard, empirical evidence for conclusions about how ads influence people. With voice-over, sound effects, and music, such artifacts are tremendously complex from an aural standpoint and when the visual aspect is considered as well, the complexity is compounded. How can one element be completely isolated from the others to determine its effectiveness? Readers are encouraged to seek out work in psychology, political science, media studies, and other fields to inform their understanding of this complicated issue. Sources in the bibliography of this volume can be a good place to continue.

My purpose is not to analyze only those ads that have made a name for themselves for other reasons. Rather, I discuss ads where I find the use of 
music particularly inventive and effective in communicating to viewers, especially where music is the argument per se. Sometimes ads that are effective from a musical point of view go nearly unnoticed by the media and political or social historians.

Savvy about advertising was not spread equally between the two parties. It should become apparent through the course of this book that one party has taken political ads and their music more seriously by pouring more money and energy into producing and airing them. Their music has in the main been more creative and innovative, and some of their ads remain in the public consciousness as cultural touchstones. As we will see in Chapter 1, one party was quick to embrace advertising's methods while the other hesitated. For this reason, both major parties are not covered equally in this book.

Not all ads are equally prominent or influential. Certain ones are discussed in the media, particularly if they are especially scandalous or controversial such as LBJ's "Daisy" ad or "Who Hasn't?" the racially provocative Republican National Committee viral ad against Harold Ford, Jr. in the 2006 Tennessee US Senate race. ${ }^{63}$ Then they take on a life of their own, sometimes to the detriment of the candidate whose campaign ran the ad and sometimes to his benefit. Ads that are part of the culture- "I Like Ike," "Morning in America," "Willie Horton," and the like-are remembered today because of the impact they had at their time. Music played a central part in most of the ads that are known in popular culture. I hope that this study will contribute in a small way to a re-evaluation of how persuasion works in political ads.

The general trajectory of music in political ads is a transition over time from commercial jingles to complex minidramas with subtle underscoring. The most recent trend, over the past few general election cycles, has been toward music that calls attention to itself in clever ways, whether by a mash-up of the candidate's speech along with popular music singers and actors ("Yes, We Can," 2008) or by using an unfortunate performance of a patriotic song by an opponent against him ("Firms," 2012). Music has returned to being self-conscious, but often with a sardonic twist.

For 2012, about $\$ 7$ billion was spent, whether by independent entities, PACs, or the candidates' campaigns. ${ }^{64} \mathrm{Of}$ this sum, estimates are that roughly

63 The incumbents behind both ads ultimately won re-election.

64 Tarini Parti, " $\$ 7$ billion spent on 2012 campaign, FEC says," Politico $<$ http://www.politico. com/story/2013/o1/7-billion-spent-on-2012-campaign-fec-says-87051.html>. Accessed April 17, 2015 . 
2.1 billion was spent by outside political groups ${ }^{65}$ According to Huffington Post, a total of $\$ 690$ million was spent on television and radio ads, with another $\$ 218.7$ million on online ads. ${ }^{66}$ Online political advertising, a significant and powerful phenomenon in the universe of political discourse, moved toward becoming a $\$ 1$ billion industry for the 2016 election, ${ }^{67}$ as political advertising has continued its shift from television to online platforms. So although it is a lot of money, it is spent gladly because political advertising is perceived as a necessary investment. With record amounts spent each general election cycle, particularly in the wake of the 2010 Citizens United Supreme Court ruling, there is no end in sight. This book will attempt to explain a bit about what campaigns are getting for their money and why it should interest us all.

65 Ibid.

66 Sam Stein and Paul Blumenthal, "Obama 2012 Campaign Spending Buried Romney On Airwaves and with Staff," Huffington Post, December 12, 2012 < http://www.huffingtonpost. com/2012/12/12/obama-2012-campaign-spending_n_2287978.html>. Accessed April 17, 2015. 67 Robin Respaut and Lucas Iberico Lozada, "Digital Strategy Firms Could See Tripling of Political Ads," Las Vegas Review Journal, April 14, 2015 <http://www.reviewjournal.com/business/ retail/digital-strategy-firms-could-see-tripling-political-ads $>$. Accessed April 17, 2015 . 


\section{The Age of Innocence: $195^{2}$}

In 1952, Elizabeth II acceded to the throne of the United Kingdom. The world learned from Prime Minister Winston Churchill that Great Britain had developed the atomic bomb (it was tested in October of the same year). Fulgencio Batista returned to power in Cuba. A peace treaty between Japan and the United States was ratified. Anne Frank's diary was first published in English. Puerto Rico wrote and approved a Constitution, becoming a commonwealth of the United States with some autonomy. John Cage's experimental piece 4'33" saw its premiere in Woodstock, New York. The first hydrogen bomb was detonated by the US at an atoll in the Pacific Ocean. Eisenhower traveled to Korea to try to bring the conflict to a conclusion. A front-page report in The New York Daily News detailed the successful sexual reassignment surgery of Christine Jorgensen.

Characteristic of the first decade of presidential television political ads is the naïve earnestness with which politicians, political entities, and ad agencies address the public. They had the same approach as product commercials. The "hard sell" approach was the style championed by ad creator Rosser Reeves; his most famous example might be a cartoon rendering of hammers pounding inside a man's head in a 1950s spot for Anacin.

The majority of ads treated voters as thoughtful beings and made appeals either to logos (focusing on a candidate's issue stances or previous accomplishments) or to ethos (featuring respected authority figures endorsing the candidate). According to Aristotle in Ars Rhetorica, there are three modes of persuasion: logos (appeal to reason), ethos (appeal through the speaker's character), and pathos (appeal to emotion). Product commercials of the time discussed products' features, such as effectiveness, durability, and price, and compared them to those of the competition (logos); they also used celebrities to speak in favor of products (ethos). What they did not often do was to make an appeal to emotion (pathos). Political ads in this decade followed suit by discussing candidate stances on specific issues more often than is done these days.

In addition, in ads from the 1950s, candidates treat each other with respect, each accepting as axiomatic that an opponent is well-intentioned, albeit with a different worldview. There is no hint of the kind of ruthless ad hominem attacks, scandal seeking, and muckraking that would characterize campaigns in decades to follow - and, it must be noted, had characterized elections in early America-where at times it is implied that the country will devolve into a post-apocalyptic dystopia if the opposing candidate is 
elected to serve for the next four years. Decorum and decency were the order of the day.

Finally, music appears rarely in political ads of the 1950s, more rarely than in commercials. When it is present, it is usually as a jingle or for general atmosphere. It won't be used rhetorically—as an argument unto itselfuntil the end of the next decade, when the Nixon campaign will use it to great effect in both advocacy ads and attack ads against Hubert Humphrey. First we will examine one of the most iconic television ads in US history.

\title{
CASE STUDY \\ Ike for President \\ Citizens for Eisenhower \\ Producer: Roy (Oliver) Disney \\ 01:00
}

Because the Eisenhower Library contains the extant original documents associated with his two presidential campaigns, we can learn something about how "I Like Ike" ("Ike for President") was conceived and produced. Addressed to "Mr. Roy [O.] Disney, Plaza Hotel, New York City," a Western Union telegram of September 30, $195^{2}$ written by campaign operative Jacqueline Cochran ${ }^{2}$ reads:

\begin{abstract}
JUST TALKED TO MR. JOCK WHITNEY TO TRY TO GET ASSURANCE THAT YOUR WONDERFUL SHORT WOULD HAVE NATIONAL TELEVISION COVERAGE STOP I AM WIRING MR. WHITNEY TO PHONE YOU AT PLAZA STOP I PERSONALLY BELIEVE THE PROPOSED SHORT COULD BE THE GREATEST PIECE OF PROPAGANDA IN THIS WHOLE CAMPAIGN AND I CERTAINLY HOPE IT CAN GO ON A NATIONAL HOOKUP. ${ }^{3}$ THANKS AND REGARDS.
\end{abstract}

JACQUELINE COCHRAN

1 The Presidential Records Act of 1978 complicates public access to the records of Ronald Reagan and his successors.

2 Cochran had an exciting life in her own right as a military and commercial aviator, test pilot, cosmetics business owner, Republican congressional candidate, and friend and campaign worker of Eisenhower.

3 This and the following full stop after "regards" are in the original telegram. 
A letter of October 2,1952, by Cochran and addressed to Mr. George Carlson of the accounting firm Ernst \& Ernst and with copies to Paul Helms and William Anderson, reads:

Dear Mr. Carlson:

A large group of artists, musicians, lyricists and producers of the Walt Disney organization have gotten together and, on a voluntary basis on their own time, are in the process of producing a most extraordinary one minute short which is an animated cartoon called "WE LIKE IKE". They are also producing a 20 second animated cartoon in the same character.

The lyrics that accompany this one minute short and the plans for the short have been presented to several people, including Mr. Paul Hoffman and Mr. Paul Helms, and everyone is overwhelmingly impressed and enthusiastic over this piece of propaganda.

The only expense involved in connection with these two shorts is certain laboratory costs which it is impossible for the group at Disney's to contribute.

Mr. Paul Helms contributed \$1000., which has been deposited in the special account you are handling, and he gave me permission to use his contribution for this purpose.

Mr. William Anderson of the Walt Disney Studio will submit to you in the next ten days an invoice, covering the laboratory costs incurred in making these cartoons and the cost of making several prints. These costs will not exceed $\$ 1000$. Will you kindly send Mr. Anderson a check to cover the invoice.

Sincerely, Jacqueline Cochran ${ }^{4}$

Dated October 9, 1952, a music cue sheet for what was called "We'll Take Ike" reads:

Sponsored by "Citizens for Eisenhower Committee"

I. - 1 minute spot:

"We'll Take Ike"

Words and Music: Gil George and Paul Smith

Publisher Assigned: Walt Disney Music Company 
Total Footage: 90 feet

Total time: $\quad 60$ seconds

Usage: Visual Vocal—Complete

II. - 2o second spot:

"We'll Take Ike"

Words and Music: Gil George and Paul Smith

Publisher Assigned: Walt Disney Music Company

Total Footage: $\quad 30$ feet

Total Time: $\quad 20$ seconds

Usage: Visual Vocal—Partial

In a letter written to Jacqueline Cochran on November 14, ten days after the election, Roy O. Disney writes:

Dear Miss Cochran:

As requested in your letter of November 6th I am enclosing a list of the Disney employees who contributed their time and efforts to the production of the Eisenhower cartoon.

The boys and girls all enjoyed working on the project and, of course, we are all very happy at the outcome of the election.

Kindest regards.

ROD: MW

Sincerely,

[signature]

Enc. ${ }^{5}$

Roy O. Disney

The enclosed list contained the names of 53 people who contributed to the ad. At the top were Gil George and Paul Smith. Smith was correctly listed as "Composer," but George was listed as "Nurse," which was crossed out and "Song Lyrics" written in by hand. (Her day-to-day job was a nurse for Walt Disney.) 
"Ike for President" is a catchy tune that burrows its way into viewers' minds upon the first hearing. Part of its contagious character can be attributed to the ostinato in the bass, "Ike for President." The ostinato is a repetitive tonal motive (1 Ike-5for-6Pre-si- 7 dent $-1 \mathrm{Ike})$, which occurs fifteen times in the ad in exactly this guise (see Figure 1.1), and another four times with the same words and different melodies. With "Ike" as the word on the resolution of the tonal and rhythmic tension, the ad situates Eisenhower positively. The general character of the cartoon ad is jauntily militaristic, with parades of citizens following an Uncle Sam drum major.

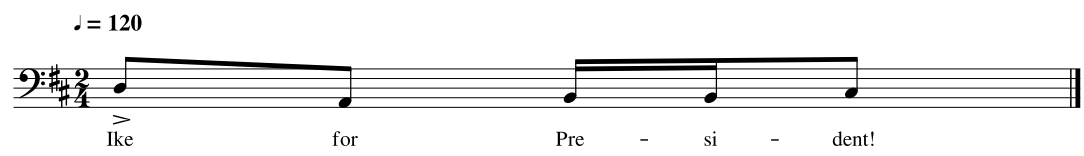

Fig. 1.1: Bass line of Eisenhower's "I Like Ike"

Eisenhower's nickname receives metrical, rhythmic, and tonal emphasis: "Ike" is heard at the beginning of every measure, it is accented, and it is on the tonic. "President," on the other hand, is unstressed, and is on the submediant and leading tone. In fact, the word "Ike" is given so much prominence, one might almost get the impression that Eisenhower's personality is more important in this ad than the Presidency itself.

At first we see "Eisenhower for President" across the screen with a bouncing IKE campaign button underneath while music plays. The ad starts in $\mathrm{D}$ major, later changing keys to the remote key of $\mathrm{F}$ major. The tempo is 120 beats per minute, the most common tempo for marching. After the bouncing button, we see a drum major, an elephant with caricature of Eisenhower around his body, an IKE banner proudly unfurled from his trunk, and beating a rolling bass drum with his tail in time to the music. Subsequently we see a parade of men and women whose professions are clearly identifiable by their clothing: businessman, cook, nurse, cowboy, banker, pipefitter, teacher.

Here is the transcript of "Ike for President": 
[TEXT: A PAID POLITICAL ANNOUNCEMENT. PAID FOR BY Citizens

for Eisenhower.]

[TEXT: EISENHOWER FOR PRESIDENT]

GROUP (singing): Ike for president, Ike for president,

Ike for president, Ike for president.

You like Ike, I like Ike,

Everybody likes Ike-for president.

Hang out the banners, beat the drums,

We'll take Ike to Washington.

We don't want John or Dean or Harry.

Let's do that big job right.

Let's get in step with the guy that's hep.

Get in step with Ike.

You like Ike, I like Ike,

Everybody likes Ike-for president.

Hang out the banners, beat the drums,

We'll take Ike to Washington.

We've got to get where we are going,

Travel day and night-for president.

But Adlai goes the other way.

We'll all go with Ike.

You like Ike, I like Ike,

Everybody likes Ike-for president.

Hang out the banner, beat the drums,

We'll take Ike to Washington.

We'll take Ike to Washington!

Ike for president, Ike for president, Ike for president, Ike for president ...

[TEXT: VOTE FOR EISENHOWER]

MALE NARRATOR: Now is the time for all good Americans to come to the aid of their country. Vote for Eisenhower. 
As we hear, "We don't want John or Dean or Harry," we see Democratic donkeys behind a fence: curly-haired John Sparkman (Senator from Alabama and Stevenson's running mate), mustachioed Dean Stockwell (Secretary of State under Harry Truman), and bespectacled Harry Truman. Then the parade continues, and we see a businessman, firefighter, painter, milkmaid, architect/draftsman, and police officer. After that, a farmer appears alone driving a tractor, followed by a couple with a dog and baby. At "But Ad-uh-lay goes the other way" we are treated to a caricature of Stevenson in shadow on donkey, riding in the opposite direction of Ike and everybody else in the parade; Stevenson is of course riding to the left (as we might expect a left-winger to do).

Subsequently, with an abrupt key change to $\mathrm{F}$, we get the drum major again, followed by the bass drum beating elephant; these repeated elements neatly frame the ad as it comes to a close. Then we see a plane flying over the US Capitol Building with-what else? - an "IKE" banner. After that, a close-up on the Capitol dome, and a pan up with the sun rising behind it as the music reaches its climax with a high F. The sun has an IKE label, making the choice of Eisenhower for President a solar system-wide choice. A striking modulation from $\mathrm{D}$ to $\mathrm{F}$ - a key three accidentals removed-lends energy and momentum to the ad just as viewer attention might begin to flag.

Finally, we see the Eisenhower for President with the "IKE" campaign button tableau, though this time the button has settled down and remains still even as the "Ike for President" ostinato resumes. The narrator intones: "Now is the time for all good Americans to come to the aid of their country. Vote for Eisenhower." The famous "Now is the time for all good Americans to come to the aid of their party" typing test becomes a party-transcending appeal to voters to be there for their country, because (it is implied) a vote for someone beside Eisenhower must be an antipatriotic betrayal. It is a call for all good Americans to come to the aid of "their" party, after all. Good Americans belong to the Republican Party, it would seem. Voting for Eisenhower is presented here as a patriotic act that is for the good of the nation, leaving the converse proposition unspoken: are those voting for Stevenson unpatriotic?

This ad has a communal aspect, inherent in the choral nature of the music. One gets the impression of crowds of supporters expressing their intention to vote the Republican ticket. This stands in stark contrast to the Stevenson ad of the same year featuring a solo jazz singer who sings "I Love the Gov'," which we will examine subsequently. Whereas the woman in "I Love the Gov'" seems to be singing directly to each voter in an intimate setting, "I Like Ike" has all manner of people singing together in harmony 
about their choice. Ironically, jazz, the medium of the Stevenson ad, is the milieu from which the term "hip" came, but "I Like Ike" presents the former five-star general as the hip cat: "Get in step with the guy that's hip" [pronounced "hep"].

As a curious aside, we might note that the text of "I Like Ike" is strikingly similar to a Negro spiritual, "All God's Chillun." ${ }^{\text {T }}$ The similarity between the two songs does not end with the parallelism of the lyrics; it also extends to the melody and rhythm, which are so close that one has to wonder whether the composer of the song was subconsciously mimicking the spiritual or even intentionally doing so.

You like Ike, I like Ike, everybody likes Ike (for President)

I got wings, you got wings, all God's chillun got wings.

\section{Love the Gov'}

\section{Stevenson}

01:20

The contrast between "I Like Ike" and its counterpart for the Stevenson campaign could hardly be more apparent. Stevenson was finding it difficult to present himself as a man of the people in relation to Eisenhower. ${ }^{7}$ Visual and aural elements in "I Love the Gov" imply elite status. Music here is too clever by half, a bit too sophisticated for a political ad. In contrast, the simple music and lyrics for "I Like Ike" as well as the march genre seem much more suited for a mid-century political advertisement.

Music here is intimate - a piano accompanying a female singer. In essence, lounge music in F major. Standing in front of a camelback sofa, we see a woman in an elegant black sleeveless evening gown with a prominent belt, brooch, necklace, and earrings. She is well-coiffed, relaxed, and she smiles at the camera as she sings. The ad is fairly cringe-worthy for contemporary viewers.

Lyrics in "I Love the Gov'" are too complex to be completely grasped after just a couple of viewings. "A man with a hole in his shoe" is of course

6 I am grateful to one of the anonymous reviewers of this manuscript for this valuable insight.

7 Barton J. Bernstein writes, "Prior to the nomination Stevenson emerges as a man of selfdoubt, uneasy modesty, indecision, ambivalence: he would not seek the office nor would he refuse it. He sought power, prestige, and responsibility, but he also felt unworthy, inadequate, unsure, " "Election of 1952," in The Coming to Power: Critical Presidential Elections in American History, ed. Arthur M. Schlesinger (New York: Chelsea House, 1981), 408. 
Stevenson, who was the subject of a Pulitzer Prize-winning photo taken by Bill Gallagher during the candidate's $195^{2}$ campaign.

The first line attempts to turn the weakness into a strength. Here is the transcript:

WOMAN (singing): I'd rather have a man with a hole in his shoe

Than a hole in everything he says.

I'd rather have a man who knows what to do

When he gets to be the Prez.

I love the Gov', the Governor of Illinois.

He is the guy that brings the dove of peace and joy.

When Illinois the GOP double-crossed,

He is the one who told all the crooks, "Get lost."

Adlai, love you madly,

And what you did for your own great state,

You're gonna do for the rest of the 48 .

Didn't know much about him before he came,

But now my heart's a ballot that bears his name.

'Cause listen to what he has to say,

I know that on election day,

We're gonna choose the Gov' that we love.

He is the Gov' nobody can shove.

We'll make the Gov' the president of the you, the me, and the USA!

The whole raison d'être of this ad is as a response to "I Like Ike." Naming an ad in a way that evokes one's opponent's ad (one which is better produced to boot) is not a winning strategy. Certain feminized aspects of Stevenson's onscreen demeanor appear magnified somehow by this woman. The singer conveys an open sexuality; as she sings, she flirts with the camera. She doesn't just "like Ike," she "loves the Gov'" American voters rarely express love for a candidate, as it seems too extreme an emotion for a constituent to have for his or her government representative.

In contrast to the join-the-parade-be-one-of-the-crowd welcoming nature of "I Like Ike," "I Love the Gov"' is an intimate appeal. This is no movement, no sense of commonality-only a woman singing seductively to the camera. Instead of an orchestra and chorus, there is a pianist and a singer. It's the type of ad that might have turned off some female viewers and made some male viewers uncomfortable.

By its very nature, seduction is a private act. A winking eye can suggest a secret shared between two lovers (or potential lovers). It certainly does not 
invite others into the closed circle of trust. So a voter might subconsciously accept the idea that voting for Stevenson is a private act - not to be shared with others. The genre of the lounge jazz song supports this idea. Although performing in front of a group, a singer in a lounge setting intends to make each man imagine that she is singing to him and only him.

But even if we reject the lounge singer trope as too on the nose, this singer in this setting would otherwise be singing to a select group of individuals at a private party, the type of establishment where a Schubert song is played and sung by family members of the host or hostess. So in any reading this is music for a small number of people, and it doesn't come across as music for the masses.

This type of jazz music does not invite, it excludes. It might seem as though viewers are intruding on an intimate moment. In contrast, Eisenhower's chorus and parade of "just folks" from all walks of life in "I Like Ike" is plainly inclusive. All are invited to join in. The march's military aspect also comports with the normative masculine viewer's expectations for a presidential candidate. Ike's ad is comfortable and reassuring, in a way that Stevenson's is not. The contrast between these ads vividly illustrates the different ways the two candidates were perceived by the American public.

Music is able to reinforce or countervail such stereotypes, and not only in broad strokes such as female/male, intimate/public, or jazz/march, but it can also highlight dichotomies such as urban/rural, rich/poor, sophisticated/ simple, and so on. A march-like "I Like Ike" conveys a masculine sensibility; it avoids subtlety and nuance like that in "I Love the Gov"”.

\section{Adlai to You \\ Stevenson \\ 00:15}

One ad introducing Stevenson to voters outside of Illinois made a point of his unusual and unfamiliar given name. Stevenson had holes in his shoes and was a Princeton intellectual ${ }^{8}$ and an American blueblood. The Stevenson family was prominent in Illinois politics. Many Americans had trouble identifying with the man given his social and intellectual capital. He came across as earnest but stiff and somewhat aloof. Whenever a candidate feels the need to give voters a tutorial on how to pronounce his name, he is already at a disadvantage. Eisenhower (and many men in his family) had 
had the nickname "Ike" since childhood, so it was natural for him to use it during his campaigns. Easy to remember and conveniently rhyming with "like," "Ike" was a winner's name.

The animated figure in "Adlai to You" begins as a mortar-boarded, gowned professor with a baton pointing to "ADLAI," written twice on the blackboard. Two-thirds of the way through, the "prof" jumps up and turns around, at the same time transforming into Uncle Sam. He then marks an $\mathrm{X}$ under one of the Adlais and the name "Stevenson" appears.

As in "I Like Ike," there is choral singing, but here, curiously, there are only male vocalists. Accompanying the male chorus is a piano with a simple $\mathrm{I}-\mathrm{vi}-\mathrm{i}-\mathrm{V}$ chord progression in $\mathrm{C}(\mathrm{C}-\mathrm{Am}-\mathrm{Dm}-\mathrm{G})$. "Adlai" is only mentioned four times in the fifteen-second spot, and his surname only once. But the first name is pronounced two different ways, each sung twice. In the end, viewers never learn what the correct pronunciation might be. The final cadence in piano is answered a cappella by the chorus "Stevenson!" This highlights his surname prominently. Nevertheless, "Adlai to You" is a relatively ineffective ad in general, not least because of the music.

In the next chapter, we will find less music in the ads, but again it will be the Republican candidate who used music to make an ad stand out from the rest. 


\section{Still Liking Ike: 1956}

In the eventful year of 1956 the films Richard III (with Laurence Olivier), My Fair Lady, and Cecil B. DeMille's The Ten Commandments were released. Elvis Presley hit the US charts for the first time with "Heartbreak Hotel," months later shocking audiences with his gyrating hips while performing "Hound Dog" on The Milton Berle Show. Don Larsen pitched a perfect game for the New York Yankees in Game 5 of the World Series and a thirteen-year-old Bobby Fischer defeated Donald Byrne, a grandmaster, in the Game of the Century. Arthur Miller was called to testify in front of the House Un-American Activities Committee. Morocco and Tunisia declared independence from France and Pakistan became the first Islamic Republic. The SS Andrea Doria and SS Stockholm collided, the Suez Crisis erupted, and the Soviet Union squelched the Hungarian Revolution. Eisenhower signed a congressional resolution making "In God We Trust" the national motto.

During an extended period of peace and prosperity (and incidentally ideal conditions for advertising to flourish), voters largely saw no reason to "change horses mid-stream" and additionally, many Americans admired the Man from Abilene. So as predisposed as voters were toward Eisenhower in 1952, they were even more so four years later, when Eisenhower picked up two more states in the electoral college than he had won in $195^{2}$.

A series of Stevenson ads featuring the Text "How's that again, General?" calls into question a number of Eisenhower's statements in comparison to his job performance. Some other ads, long ones, talk about the "Man from Libertyville: High Cost of Living." In "Peace is Non-Partisan," Stevenson speaks with a young Senator John F. Kennedy, during which they discuss the fear of communism spreading around the world. None of these ads has any music. In fact, Stevenson eschewed music in his second campaign. The Eisenhower campaign used ads only sparingly in 1956, but music was an important part of the campaign in television speeches and interviews, televised rallies, and whistlestop appearances.

Music was never far from the minds of those working on Ike's campaign. In a March 2, 1956 letter to National Citizens for Eisenhower, activist C. Langhorne Washburn (on the Subcommittee on Program Planning for the 1956 Republican National Convention) writes of the necessity of producing "a hard-hitting, omnipurpose film which will dramatically document in newsreel fashion the accomplishments of the Eisenhower administration. This film must be of the highest caliber and feature a unique fast-pace editing technique which will utilize every proven device to assure an 
emotional impact [...] A strong musical score and powerful commentary (by the former narrator of The March of Time) will complete the 'impact' nature of presentation."

The Television Plans Board wrote in August 1955 "A Proposal: Television Campaigning for President Eisenhower." In the proposal, the Democrats come in for criticism for their previous performance in 1952: "The Democrats were woefully weak in their ad agency selection during the last campaign, but they are not going to make such a mistake again."3 The proposal further recommends advertising agencies Batten, Barton, Durstine \& Osborn and Young and Rubicam for their "excellent work in the last campaign."4 The proposal also offers a fair amount of constructive criticism to the Republicans: "There are areas that can stand improvement. For instance: better time periods and wider coverage [...] present camera action is extremely static $[\ldots]$ the film quality could be improved [...] an occasional visual aid could be added to highlight a basic thought." 5 The report concludes with more critique of the Democrats' work in the past election as well as acknowledgment of the necessary high costs of advertising: "The Democrats slipped badly in the last campaign by not selecting prime-viewing periods while the Eisenhower periods were generally the best (even though in some cases it was necessary to 'pay through the nose.')"

\section{Taxi Driver and Dog \\ Citizens for Eisenhower \\ Producer: Young and Rubicam \\ 04:20}

Many of the ads for Eisenhower's second campaign are individual appeals, mostly by women: "Housewife," “College Girl," "Lena Washington." They bear witness to the prosperity of the country and credit that to Eisenhower's

1 C. Langhorne Washburn, letter to National Citizens for Eisenhower, Eisenhower Presidential Library, Abilene, Kansas, 1 [emphasis in original].

2 Television Plans Board, “A Proposal: Television Campaigning for President Eisenhower," Eisenhower Presidential Library, Abilene, Kansas.

3 Television Plans Board, "A Proposal: Television Campaigning for President Eisenhower," 8 [emphasis in original].

4 Television Plans Board, "A Proposal: Television Campaigning for President Eisenhower," 9.

5 Television Plans Board, "A Proposal: Television Campaigning for President Eisenhower," 20.

6 Television Plans Board, “A Proposal: Television Campaigning for President Eisenhower,” 28 [emphasis in original]. 
leadership. Eisenhower's 1956 campaign extended the themes of 1952, especially that of the President's readiness to lead. One of the spots features an ordinary citizen, a taxi driver with his dog standing under a street lamp just outside the White House.

In the four-minute "Taxi Driver and Dog," a taxi driver is presented as Everyman, the average American citizen who works for a living. The character is in awe of the White House, the Presidency, and Eisenhower. He trusts the President to be able to handle problems both foreign and domestic. He reflects a widespread opinion about Eisenhower's fitness for the job. It wasn't as though Stevenson was a complete tyro in American politics - he had worked briefly at the State Department and as a delegate to the Preparatory Commission of the United Nations Organization before becoming Governor of Illinois. And many Presidents of the United States have been governors of their states before being elected to the highest national office (seventeen in all). But even that considerable experience could not vault him above Eisenhower's experience as Supreme Allied Commander in World War II and incumbent President. (Ike's winning personality was another bonus.) So the taxi driver tries to assure the viewer that Eisenhower "can stand up to Khrushchev and these fellows" while simultaneously noting Eisenhower's humble beginnings and understanding of the problems of ordinary people.

Organ music in "Taxi Driver and Dog" recalls radio dramas such as The Shadow, True Detective Mysteries, or Quiet Please. The organ grants the scene a mysterious air; the implication is that affairs in the White House are too complicated and arcane for the average citizen - a taxi driver- to comprehend, let alone be able to deal with. The ad's music implies that the President deals in a world of drama and mystery. This fascination with Eisenhower's singular ability to lead the executive branch of the government positions Eisenhower as the only serious choice for President. So the mysterious aura and sense of wonder surrounding 1600 Pennsylvania Avenue is created solely by the organ, which we hear beginning at oo:12.

To many ears today, the music might sound strange, otherworldly, certainly dated, perhaps even a bit corny. But television viewers of voting age in 1956 (born in 1935 or earlier) had either grown up with radio dramas or enjoyed them as adults. For these programs, such music was commonplace as introductions, transitions, and outros. In fact, the organ was the instrument of choice for all types of radio programs involving mystery, horror, and the supernatural. The ad begins with an air of film noir: we see a shadowy figure with a dog approaching a street light. We almost expect to see Sam Spade stop at the light and fire up a cigarette. 
Music in "Taxi Driver and Dog” seems to sneak in inobtrusively, almost like a bridge of a radio drama rather than its opening theme. The effect is that we feel as though we have joined the story in medias res. George Davis writes about composing for the radio drama: "Often the Lead-in itself contains elements of a bridge, that is, the Narrator's first words reflect a reaction to the scene just closed, and in the course of the narration the next scene is introduced."7 Radio drama music encourages viewers to imagine dramatic episodes to come in American's future, episodes that Ike would presumably bring to a satisfying and safe conclusion. Viewers of voting age in 1956 were familiar with radio dramas, so this type of music could be used to set the atmosphere for the ad. If the purpose of a commercial is to create a lack in the viewer that will be satisfied by the product being hawked, then the lack created by "Taxi Driver and Dog" is voter anxiety and concern about the future with an untested hand at the helm.

Stevenson's famous quote "The idea that you can merchandise candidates for high office like breakfast cereal-that you can gather votes like box tops - is, I think, the ultimate indignity to the democratic process" makes clear his opinion of candidates having to make offerings at the altar of the television god in order to be elected. His stance may account for the fact that there is no music at all in Stevenson's ads from 1956: His campaign never fully embraced the medium or used it to its fullest extent. He may have felt that anything not directly related to the message he was trying to deliver was a distraction. This seems to be the case for Democrats in subsequent elections, so it is possible that the party's apparent discomfort with having to approach campaigning like marketing consumer goods was already deeply rooted in the 1950s. Eisenhower's campaign seemed unencumbered by such scruples.

Other songs were written for the election. Irving Berlin wrote "They Like Ike" for the Broadway show CallMe Madam, which was later rewritten as "I Like Ike." On the same recording by Gotham Recording Corporation, there was an excerpt from an Eisenhower speech about "Duties of the Voter" for a total of five minutes and a cost of \$1.6o. "The Eisenhower Victory March," "Ike," "I Go for I-K-E," and "I Still Like Ike" (also by Berlin) are examples. Sheet music for Berlin's "I Like Ike," the most popular song of the election, was available from Schirmer's. None of the above was related to "I Like Ike" music for the $195^{2}$ ad made by Disney.

An ad called "Cartoon Guy" has no music, but it does bring to mind music when the animated character says at the end “Me? I like Ike!" In this way he 
conjures up the "I Like Ike" ad from $195^{2}$ and other musical renditions using the phrase. Constant repetition of the euphonious phrase keeps Eisenhower in viewers' minds.

Attempts to soften Stevenson's image and humanize him in 1956 with ads such as "The Man from Libertyville: High Cost of Living" fell flat. Eisenhower, on the other hand, was a hero from World War II and was seen as the man to "stand up to the commies." Stevenson had an uphill battle to fight, which he not surprisingly lost to the former general.

In the next chapter we will see the Democrats take charge this time with a crackerjack of a jingle, one that has, like "I Like Ike," gained a place in the pantheon of memorable TV political ads. 


\section{The New Frontier: 1960}

In 1960, a number of African countries gained independence from France.

Construction started on the Aswan Dam. Four black students staged a sit-in at a Woolworth's lunch counter in Greensboro, North Carolina. France concluded its first atomic bomb test. An announcement was made that the US intended to send 3,500 soldiers to Vietnam. Brasília became the new capital of Brazil. President Eisenhower signed the Civil Rights Act of 1960, making it law. The US Food and Drug Administration approved the birth control pill. Israel's Mossad abducted Adolf Eichmann from hiding in Buenos Aires so that he could be tried for war crimes in World War II. A peaceful military coup d'état took place in Turkey. The first televised debate occurred between Kennedy and Nixon. Khrushchev famously banged his shoe on a table at a UN General Assembly meeting to defend criticism of Soviet policies. In 1950, 10\% of American households had a television set; ten years later, the number was 90\%.'

During the 1960 campaign, music was used much the same way as it was used in political ads from the previous decade. That is, it is typically absent and where present, it works in direct, uncomplicated ways. John F. Kennedy's “Jingle," for instance, strives only to plant an insistent bug in our ears, one that will repeatedly play in our heads long after seeing the ad; there is little rhetorical use for this music. ${ }^{2}$ Music in television political ads in 1952, 1956, and 1960 had consisted of commercial-like jingles, jazz or popular songs, and organ music like that heard in early radio dramas.

\section{CASE STUDY}

"Kennedy: Jingle"

Citizens for Kennedy-Johnson

01:00

In Season 1, Episode 10 of the fictional television show Mad Men ("Long Weekend"), at about 03:20, creative director of the Sterling Cooper advertising firm Don Draper discusses with his employees the Kennedy jingle. As it is projected onto a screen in a darkened room, they talk: "It's light, it's fun,

1 Andrew Cracknell, The Real Mad Men: The Renegades of Madison Avenue and the Golden Age of Advertising (Philadelphia: Running Press, 2011), 17.

2 The exception to this is "Hail to the Chief," which is used intentionally. 
it doesn't cloud the mind with, I don't know, issues? And it's catchy." Other characters make further comments after which they watch the Richard Nixon ad "Taxes" (from where Nixon begins talking, so without the narrator's introduction). After watching only nineteen seconds, Draper says in a disgusted manner, "Turn it off." In the episode's storyline, Sterling Cooper had been approached by the Nixon people to produce ads for his campaign.

This scene illustrates well the general perception of not just advertising executives of the time, but also of the public, As the election approached, these perceptions strengthened. Having been Vice President for the previous eight years, Nixon was well-known. But he had languished under the shadow of a popular President and struggled to appear as his own man. On the other hand, the young Senator Kennedy, whose family was fairly well-known in New England, was still somewhat unknown nationwide when he ran in 1956 for nomination at the Democratic National Convention to be Stevenson's Vice President on the Democratic ticket. He lost that ballot to Estes Kefauver, but he had entered the American political stage and became known by people who had not known him as a Senator. His persona captured America's imagination, and his persona was matched by his contemporary and stylish ad style.

As the most visually and aurally stimulating television ad in the 1960 presidential election, Kennedy's “Jingle" makes the strongest impression on the viewer of any ad that campaign season. The ad consists of a barrage of aural and visual representations of Kennedy and his name. Many signs with his name appear and the name is repeatedly sung in the jingle.

Music in the jingle for the 1960 Kennedy campaign fixes the Kennedy name in viewers' minds in the same way that the famous Pepsodent jingle imprints the product's name on viewers' consciousness ('You'll wonder where the yellow went, when you brush your teeth with Pepsodent!"). ${ }^{3}$ Jingles are created to act as musical earwigs, burrowing their way into our consciousness until we cannot get rid of them. Over time, well-done jingles can become a phenomenon of popular culture. Once people learn them, they begin to hum or sing them without much prompting. (In the present day, jingles can take on new lives as parodies on YouTube and elsewhere, whether the parodies were meant as homage or derision.)

In "Jingle," men and women sing together. It starts with a predominant note: the supertonic $G$, which sets up the dominant to follow. This gesture seizes the audience's attention, priming them to receive the message to follow. Here is the transcript: 
CHORUS:

GROUP (singing): Kennedy, Kennedy, Kennedy, Kennedy, Kennedy, Kennedy, Kennedy for me, Kennedy! Kennedy! Kennedy! Kennedy!

\section{VERSES:}

Do you want a man for President who's seasoned through and through, But not so dog-goned seasoned that he won't try something new? A man who's old enough to know, and young enough to do? Well, it's up to you, it's up to you, it's strictly up to you.

Do you like a man who answers straight, a man who's always fair? We'll measure him against the others and when you compare, You'll cast your vote for Kennedy and the change that's overdue. So it's up to you, it's up to you, it's strictly up to you.

\section{CHORUS:}

Yes, it's Kennedy, Kennedy, Kennedy, Kennedy, Kennedy, Kennedy, Kennedy for me, Kennedy! Kennedy! Kennedy! Kennedy! Kennedy! Kennedy! Kennedy!

KENNEDY!

The text of "Jingle" took Kennedy's youth, which some considered a liability in a presidential candidate, and reframed it as an asset. Of course, it is curious that Kennedy would present himself as the fresh-faced youthful candidate when he was only four and half years younger than Nixon. Famously, Kennedy debated Nixon on television in 1960, and later the majority of those polled who had watched it on TV decided that Kennedy had won (the opposite conclusion of the radio listeners). Kennedy looked young, relaxed, and comfortable during the debate, as opposed to Nixon, who had a five o'clock shadow and generally looked haggard and overtaxed (his earlier promise to visit all fifty states during the campaign had been taking its toll on his health). Kennedy's youthful and handsome appearance had much to do with his success in this new political medium. In short, Nixon did not present well on television. The televised presidential debate drew this into sharp focus.

Interspersed throughout the ad are phrases in capital letters: A TIME FOR GREATNESS, VOTE DEMOCRATIC, KENNEDY FOR PRESIDENT, LEADER FOR THE '6os. "A time for greatness," presented several times in the course of the ad, implied two key concepts the ad creators wanted viewers to identify with Kennedy. First, the campaign hoped voters would see 1960 as not only the beginning of a new decade, but also an important turning 
point for America, one that demanded new, vigorous, energetic leadership. In short, it was "time." Time for what?

Time for greatness. Nixon's experience, particularly in the arena of foreign policy, had to be defused by the Kennedy campaign. West Point-educated Eisenhower was used to delegating responsibility to his subordinates. Accordingly, he gave Nixon more assignments than any previous Vice President had had, particularly in foreign policy. ${ }^{4}$ The slogan "Time for Greatness" highlights the fact that Nixon as Vice President was completely in Eisenhower's shadow. Eisenhower was for many a great man whose military background proved his suitability for the presidency. Nixon, by contrast, was widely perceived as being well-suited to the Vice Presidency. ${ }^{5}$

The catchy tune is in F major, with an ambitus from $\mathrm{C}$ to $\mathrm{C}-$ a jaunty jig in compound time (see Figure 3.1). This compound meter makes sense because in order for the name to fit comfortably within a beat, the subdivision has to be into three parts. Kennedy's three-syllable name best fits a $6 / 8 \mathrm{jig}$, with two iterations of the name per measure. The final mention of the name Kennedy is stretched out from the original three eighth notes to the equivalent of five eighth notes. Since this displaces the name within the prosody, we are forced to hear the name in a new context, with stress on Ken-, - $d y$, and $m e$.

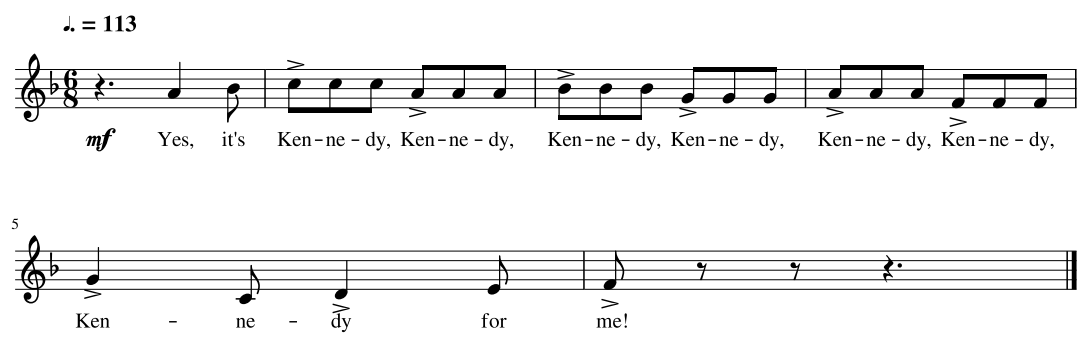

Fig. 3.1: Chorus for Kennedy's "Jingle"

4 Eisenhower sent Nixon on a goodwill tour to the Far East - which would eventually bear fruit in Nixon's own administration with his famous China goodwill tour in 1972 - and he would often chair National Security Council and Cabinet meetings in Eisenhower's absence.

5 A Kennedy ad entitled “Nixon's Experience?" showed Eisenhower answering a reporter's question " $[\mathrm{C}]$ ould you give us an example of a major idea of his that you had adopted in that role as the, as the decider and, and final ..." Eisenhower's answer must have greatly disappointed his Vice President: "If you give me a week, I might think of one. I don't remember." So Kennedy's slogan "A time for greatness" is effective at both signaling the need for change and for greatness, both lacking (it was implied) with Nixon. 


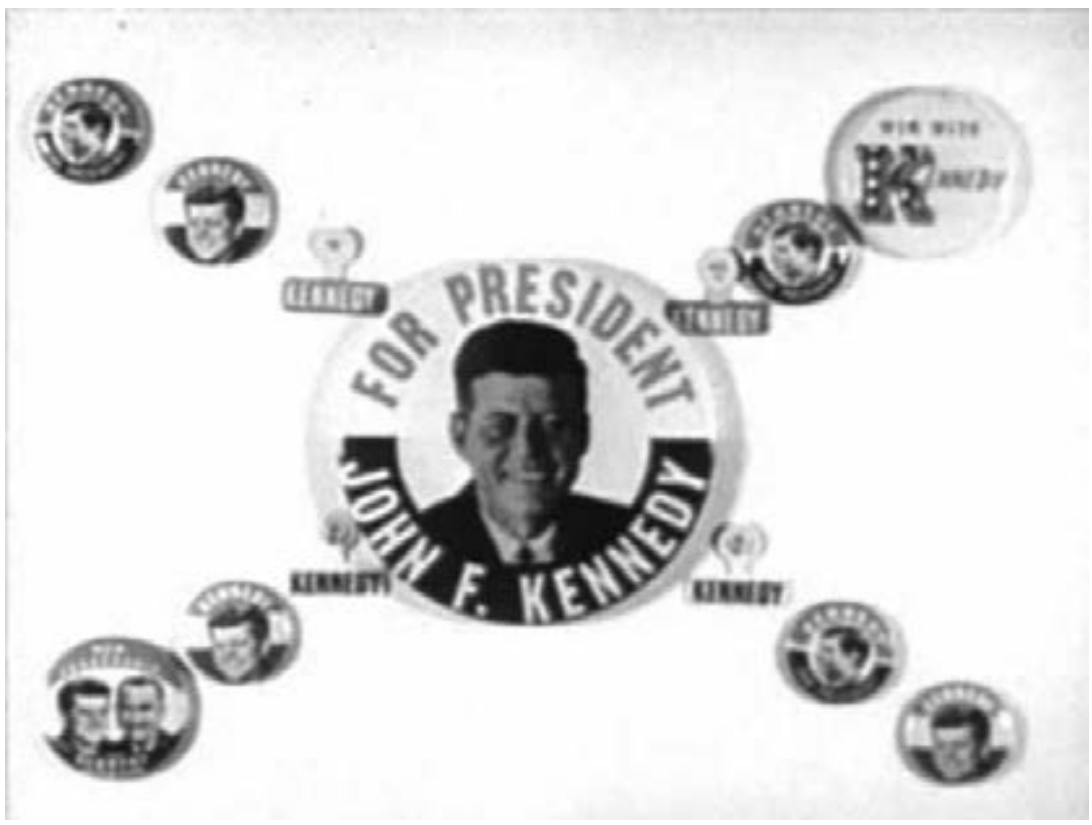

Fig. 3.2: Still of Kennedy campaign buttons from Kennedy's "Jingle"

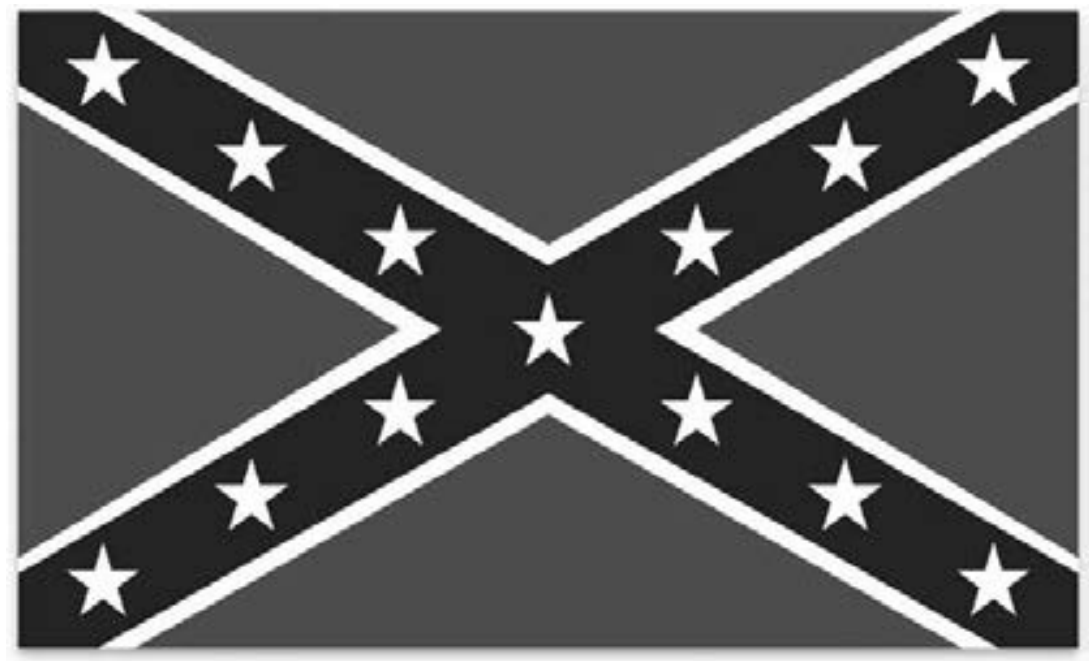

Fig. 3.3: Confederate Rebel flag

One use of music seems somewhat underhanded, and it occurs during the visual and aural climax of the ad. The ad ends oddly, with a sequence in which campaign buttons are gradually added to create an $\mathrm{X}$ shape that 
looks uncannily like the Confederate Rebel flag (see Figures 3.2 and 3.3). ${ }^{6}$ The gradual forming of this $\mathrm{X}$ shape is all over a brief musical quotation of "Hail to the Chief," which viewers might not even consciously notice unless they were paying close attention.

In a pamphlet published thirteen years earlier on how to write music for radio dramas, composer George Davis noted that a brief musical allusion can be used to great effect: "By now, the use of well-known songs to conjure an association-of-ideas is so thoroughly hackneyed as to arouse the hope that it will be eschewed. [...] Nevertheless, a suggestion of such a melody, deftly woven into the fabric of other music designed originally to accompany such scenes, is effective. The tunes are so familiar that a suggestion

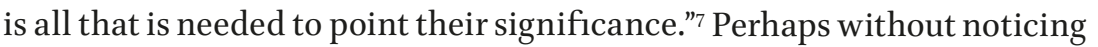
it, viewers were thinking of Kennedy, whose name and picture they were being barraged with for the better part of a minute, in the context of the Presidency thanks to a fleeting quotation of "Hail to the Chief."

If I am right about the evocation of the Confederate flag being intentional, then it was an attempt at indirect persuasion to attract Southern sympathy to the campaign and would have been thought to work on a subconscious level. Though this mimicry of the Confederate flag would not rightly be termed "subliminal," it is true that subliminal advertising was au courant in the late 1950s and early 1960s, despite the equivocacy of studies on its effectiveness. Vance Packard's highly influential The Hidden Persuaders had been published three years earlier, and it was well-known in the advertising world. ${ }^{8}$ Thus, while not equivalent to the splicing of a frame or two into a film, deploying the campaign buttons in this way might have been thought by the ad's creators to make certain viewers associate Kennedy with the South without their being fully aware of it.

Two musical allusions stand out in this ad. The later one is "Hail to the Chief," mentioned above. The first one (heard briefly at oo:08-00:10) is an Irish song known as "The Girl I Left Behind," first printed in The Charms of Melody in Dublin in 1791. With a text in most versions expressing nostalgic

6 There are the same number of buttons in the image as there are stars on the flag and the angle at which they intersect is the same as the flag. In order to win, the Kennedy campaign had to bring in some Southern states, and his selection of Lyndon Johnson as running mate was calculated to help do this. That way, his campaign could not be written off as that of an out-of-touch New England aristocrat.

7 George Davis, Music-cueing for Radio-drama:A Practical Treatise on the Application of Music to the Radio-script (New York: Boosey and Hawkes, 1947), 24.

8 Vance Packard, The Hidden Persuaders. Originally published in 1957. New York: Pocket Books, 1958. 
feelings for a sweetheart whom a soldier had to abandon in order to serve in a war, "The Girl I Left Behind" was later adopted by the English and also came into use during the US Civil War. With such associations, it is unlikely that the Kennedy campaign would have wanted viewers to make a connection to the title or any of the texts-just to the tune itself.

Including an Irish folksong in a political ad, even as short a one as a threesecond quote, was not without risk. Reminding voters of Kennedy's Irish heritage might also remind them of his Roman Catholic upbringing, which did not sit well with some voters. (A September 1960 speech by Kennedy, as well as questions posed by the public that he answered on the campaign trail, about whether his religion would affect his decisions as President went a long way toward allaying voter concerns.)

Most voters could hardly be expected to identify the title of the Irish tune, let alone its lyrics. And neither the lyrics nor the title would add anything pertinent to the campaign's message. This brief quotation was perhaps only meant to evoke Ireland in reference to Kennedy's roots. The allusion is so short, though, and is only played in the background on a penny whistle, so it is easy to miss on a first viewing. Most likely, the tune would only be noticed after repeated viewings.

Another valence of "The Girl I Left Behind" is its association with military bands, going into or returning from battle. This association, speaking about a man going off to war, could gently remind voters to recall that despite his relative youth, Kennedy had already been a decorated officer in the US Navy and a PT boat commander, military experience that presumably would testify to his readiness to become Commander-in-Chief. Ending the ad is a picture of the candidate's photogenic family as the name "Kennedy" still rings in our ears. The quote is very short, and most viewers probably did not identify the tune, particularly not in only one or two viewings.

\section{Henry Fonda \\ Citizens for Kennedy-Johnson 1960 \\ 04:20}

Connecting Franklin Delano Roosevelt to Kennedy both at the beginning and end, Henry Fonda made an ad in support of Kennedy, using the candidate's military record in the Solomon Islands in 1943. Typical of World War II newsreels, there is some dramatic music accompanying descriptions of Kennedy's naval exploits (music turns from the dramatic to the heart-tugging 
as the narrator describes Kennedy's heroism in rescuing PT boat survivors after a Japanese destroyer had rammed it). Patriotic orchestral music ends the spot on a strong note, with a powerful crescendo to a minor plagal cadence in $\mathrm{B} b$ major as we finally get the payoff of seeing the candidate's face and the text "This pre-recorded program has been prepared, edited, and sponsored by citizens for Kennedy-Johnson."

\section{Harry Belafonte \\ Democratic National Committee 1960 \\ Maker: Guild, Bascom and Bonfigli 01:00}

Kennedy took advantage of the 1950s calypso craze by shooting an ad with singer Harry Belafonte. This ad reminds viewers of dance music that many viewers liked. Belafonte's album Calypso (1956) was the first full-length album to sell over one million copies. In an overt appeal to African Americans, Belafonte advocates for Kennedy "as a Negro and as an American," by posing questions on behalf of Americans particularly "about civil rights, about foreign policy, and about the economy of the country." After Kennedy states his positions on the issues, Belafonte speaks into the camera to say, "I'm voting for the Senator. How about you?"

Though the ad has no music (only background sounds of children playing outside as the ad was being shot), viewers of "Harry Belafonte" are reminded of music. The popular calypso music Belafonte created—for example, "Matilda" (1953) and "Banana Boat Song" (1956) — would have been front and center in the minds of many viewers as they watched Belafonte advocate for the Democratic candidate. This appeal to ethos not only addresses African Americans specifically (Belafonte's advocacy in his own words is partly "as a Negro"), but also in general those for whom this music was a phenomenon.

Responding to Republican advertising savvy evident in the $195^{2}$ and $195^{6}$ elections, the campaign for a youthful, handsome, and confident Senator created an iconic political ad that approached the mastery of "I Like Ike." The ad seemed to embody America's forward-looking nature and can-do spirit, with which Kennedy's later challenge for space exploration was so eagerly embraced — the New Frontier. ${ }^{9}$

9 It should be noted that not all citizens viewed the dawning era with enthusiasm and a sense of adventure. In the sardonic lyrics of a song called "New Frontier" from his 1982 album 
As we will see in Chapter 4, some musical prowess is evident in the Democratic incumbent's campaign ads in 1964. But the Republican challenger's campaign was to deploy ads with the most compelling music, and these ads were to form the model for negative political ads in elections to come.

The Nightfly, singer/songwriter Donald Fagen alludes to Americans' fears in the early 1960s of nuclear annihilation by the Soviet Union. (The song describes the clumsy attempts of a teenage boy to charm a girl into visiting an underground fallout shelter that his father built.) 


\section{Daisies for Peace: 1964}

In 1964, President Lyndon Johnson declared a War on Poverty. For the first time, a US government official, the Surgeon General, announced that smoking might endanger one's health. Beatles albums were released by Capitol Records and Vee-Jay Records; later, the Beatles performed on The Ed Sullivan Show. The Rolling Stones released their first album. Racial segregation protests occurred in New York City. Turks and Greeks began battling in Cyprus. Cassius Clay became heavyweight champion. Ford produced its first Mustangs. A massive earthquake in Anchorage, Alaska, caused huge damage and resulted in 125 deaths. As military commitment to the Vietnam War continued, draft cards were publicly burned for the first time. Robert Moog unveiled his Moog synthesizer prototype. Martin Luther King, Jr. was awarded the Nobel Peace Prize.

Campaigns began to employ music more intentionally in 1964. Barry Goldwater in particular seemed to sense early on music's power to persuade through emotional appeal rather than discursive argument. By 1968, political ad music begins to consistently function rhetorically; that is, to present emotional appeals on its own quite apart from textual and visual elements. Shown as text at the end of his ads, Richard Nixon's 1968 slogan- "This time vote like your whole world depended on it"-implored voters with the same urgency as Democratic incumbent Lyndon Johnson's slogan in 1964, "The stakes are too great for you to stay home." Thus, 1964 marks an important bridge between the tentative musical efforts of 1960 and the cynical manipulation with music that we witness in 1968.

In its most recognizable form, the negative political television advertisement in the US seems to have been invented by the 1964 presidential campaign. Never before had ads talking about the opponent been so vitriolic, and with the infamous "Daisy" ad, Johnson's campaign literally chose the nuclear option. ${ }^{1}$ Music is present in ads from both campaigns, but is used quite differently. In Johnson's ads, music seems a distraction-most of his ads lack it. Recognizing music's persuasive power, Goldwater uses it more frequently in his ads, and to greater effect. Goldwater ads such as "Morality" and "America's Image" feature militaristic drum cadences and cymbal crashes, "scare music," and patriotic music.

$1 \quad$ Tony Schwartz worked with Doyle Dane Bernbach to produce "Daisy." He discusses this ad briefly in a book with a musical title that he wrote in the early seventies, The Responsive Chord (New York: Anchor Press, 1973). Schwartz's contribution was the girl counting the daisy petals as well as the countdown to ignition of the missiles and the overall soundscape. 


\section{Voting Booth \\ Johnson \\ Democratic National Committee \\ Doyle Dane Bernbach \\ 01:00}

The famous and dynamic firm of Doyle Dane Bernbach created for the Johnson campaign an ad that used music in an unusual way. "Voting Booth" starts with a camera following a man walking down a hallway in what appears to be a school; we later learn that his destination is a polling location, apparently a room in the school. We hear distorted music that sounds as though reproduced through a transistor radio or slightly damaged reel-to-reel tape. The first tune is "Hot Time in the Old Town Tonight," which immediately dissolves into what sound like political convention noises, which in turn yield to John Philip Sousa's Washington Post march. This is followed by more convention sounds - cheers, applause, amplified speeches.

However, when the man opens the door to the polling location, the music and sounds stop abruptly, as if to indicate that the man's thoughts are now focused laser-like on the task at hand, that the polling location is much too sacred a place for outside distractions. He doffs his hat seconds before he enters, indicating a move from public into private space. Typically, men wore hats outdoors and would take them off upon entering a building. Yet here, the hallway, though indoors, is still metaphorically public space. (This is borne out by the raucous music we hear as he traverses the hallway.) The man leaves the public arena only when he opens the door to the polling room.

Here he enters the private space, the space reserved for the man's innermost thoughts, namely: Who deserves my vote? The camera angle has shifted to show the man's face for the first time; the camera has been awaiting his arrival. As the man signs his name at the desk and approaches the voting booth with ballot in hand, the narrator says, "When it's all over, and you're in the voting booth on November third, keep this in mind: America is stronger and more prosperous than ever before. And we're at peace." (The last statement about being at peace seems at first an afterthought, but in fact, it is the lynchpin of the ad, for the Johnson campaign sought to

2 Notably, in the very next election the Nixon campaign will use this tune in an ad an enthymeme to comment wordlessly on the chaos and disorder of the 1968 Democratic Convention in Chicago. 
cast Goldwater as an extremist who would lead the country back into war. Of course, we see the irony of Johnson touting his record on peace only in retrospect.) When the man jerks the booth curtain crisply behind him, we see the text "Vote for President Johnson on Nov. 3" on the screen as the narrator intones, "Vote for President Johnson on November third. The stakes are too high for you to stay home."

Music in this ad comprises mere background, representing the tumult of presidential politics. Distortion of the music is mirrored visually by canted camera framing as the man walks down the hallway. Both visually and aurally, the first part of the ad seems to depict a world out of sync. In this context, we might infer that one of the ad's intended meanings is that the democratic process of voting remains in its own rarefied atmosphere, high above the din of quotidian political wrangling, and that voters should be careful not to get caught up in the hoopla surrounding Goldwater and his sometimes exceedingly provocative and flamboyant statements. "Voting Booth" enjoins voters to be serious and to disregard campaign bluster in order to listen to their inner voice. In "Voting Booth," music represents chaos; silence, careful reflection. After all, the narrator reminds us, "The stakes are too high for you to stay home."

\section{Poverty \\ Johnson \\ Democratic National Committee Doyle Dane Bernbach 01:00}

"Poverty," like "Voting Booth," uses music only as accompaniment to the voice-over. It seems to have been used only as a soundtrack to an ad about poverty as a social condition. In "Poverty," we hear 1930s Delta blues guitar music accompanied by rhythmic foot stomps, marking a steady beat. The playing is so simple, it sounds as though it is being played on a diddleybow. As the music plays and the voice-over is heard, the camera tracks across stills depicting poor (mostly white) children, and at times zooms in and out on faces. These pictures are reminiscent of the Farm Security Administration/Office of War Information pictures taken between 1935 and 1944, and they call to mind Franklin Roosevelt's New Deal, a widely popular Democratic government initiative. Subjects in the ad's pictures are not all clearly identifiable as penurious rural Southerners, but neither are they clearly anything else. Acoustic blues guitar and foot stomps unequivocally 
situate the pictures in the poorest area of the US, the South. And not just the South, but the Deep South. And not just any time, but the Great Depression, which hit the Deep South hardest of all.

In his January 1964 State of the Union address, Johnson had introduced the War on Poverty, which formed a significant part of his Great Society initiative. Not surprisingly, his campaign sought to highlight this in his advertising. Having ushered the Civil Rights Act of 1964 through Congress and signed it, Johnson felt vulnerable in the South as Election Day drew near. The door was open for other primary candidates to step in and take the Democratic nomination, and the one who made Johnson nervous was George Wallace, a Dixiecrat from Alabama. So, the Johnson campaign sought to publicize its War on Poverty with this ad, in an effort to appeal to Southerners who felt betrayed by the passage of the Civil Rights Act. Blues music symbolizes the desperation of the destitute, and here along with the images it says, "I'm a Southerner, I empathize, and I plan to do something about it."

Of course, much of the Great Society legislation for which Johnson is known was passed during his second term. So he did not have much of a record to go on as a poverty fighter as the November 1964 election approached - indeed, he had been President for less than a year-and his legislative record gave no clear hint that he would make a War on Poverty a presidential priority. "Poverty" helped to establish with some voters Johnson's bona fides as an anti-poverty crusader. Music is the sine qua non of the ad "Poverty," and as in "Voting Booth," music signifies something negative: in this case, hopeless desperation.

\section{Morality \\ Goldwater \\ Republican National Committee \\ Interpublic: Erwin Wasey, Ruthrauff and Ryan, Inc. 01:00}

A contrast ad, Goldwater's "Morality" begins with a political cartoon of the US Capitol Building with its dome flipped open and Bobby Baker reaching into it - presumably removing untold sums of money. Then, at the same time as we hear insistent brass playing a loud and percussive syncopated motive, a cymbal crash, military drum cadences, bass drum, the screen goes black and we see, in a cartoon-like font, the following words, one after the other: "GRAFT! SWINDLE! JUVENILE DELINQUENCY! CRIME! RIOTS!" 
These words are interspersed with images of a farmhouse, Billie Sol Estes (like Bobby Baker, his name appears on-screen), riots or demonstrations, a line of young men who appear to be criminals during a perp walk, a man fighting with baton-wielding police officers, a man being carried by police, and the east side of the US Capitol Building with trees and cars in the foreground. Bobby Baker and Billie Sol Estes, the faces of corruption and fraud scandals that implicated the Johnson Administration, reminded voters of one of the drawbacks of an incumbent President.

Almost all of the initial images are poorly lit or in darkness. Halfway through the ad, at oo:26, Goldwater himself appears, seated in a well-lit office with a window curtain behind him and a picture behind him to his left. Like a stern father figure, he speaks seriously to the audience about law and order. Goldwater speaks to the camera without music for the second half. The dark-light contrast, signifying the divide between Democrats and Republicans, mirrors the transition from music to its absence. As with Johnson's "Voting Booth," music in this ad is presented as a distraction, and its absence is meant to signify seriousness. Even Goldwater's campaign slogan — "In your heart, you know he's right" - seems to support this notion. The implication of the slogan is that, as extreme as some of Goldwater's positions or quotes may seem, he is merely stating uncomfortable truths that we would rather not admit. Listen to your heart away from the tumult and hubbub of everyday life and you will know how you must vote, he seems to imply. (Since Johnson's ad campaign implied the same thing, viewers might be forgiven for not knowing which inner voice to heed.)

Dramatic effects in this ad reflect the colossal clash of values that Goldwater presented as contrasting Democratic and Republican values. Music is heard only in the first half of the ad; it stops abruptly when Goldwater takes the screen. Pandemonium and terror in the first part of the ad is countered by sanity and rectitude in the second half, as evinced by Barry Goldwater. In his nomination acceptance speech at the Republican Convention that year, Goldwater had not modulated his apocalyptic rhetoric to appear more moderate to the general electorate; rather, he embraced his extremist label: "I would remind you that extremism in the defense of liberty is no vice. And let me remind you also that moderation in the pursuit of justice is no virtue."

In this negative ad, music is the argument, the scaffolding on which the text and images are hung; "Morality" is, albeit clumsily, using music rhetorically. Images and voice-over give the music context, giving the negativity of the music something to attach to. "Morality" strives to portray Goldwater as the more responsible candidate. For our twenty-first-century sensibility, the overall effect is comically unsubtle, but the ad adheres to conventions 
that obtained in the early 1960s. In fact, all of the ad's elements-music, voice-over, images, and text-tap conventions from B-movie trailers such as that for the 1958 film Monster on the Campus. ${ }^{3}$

Here is the transcript of "Morality":

MALE NARRATOR \#1: Graft!

[TEXT: BILLIE SOL ESTES]

MALE NARRATOR \#1: Swindles! Juvenile Delinquency! Crime! Riots!

MALE NARRATOR \#2: Hear what Barry Goldwater has to say about our lack of moral leadership.

GOLDWATER: The leadership of this nation has a clear and immediate challenge to go to work effectively and go to work immediately to restore proper respect for law and order in this land — and not just prior to election day either. America's greatness is the greatness of her people, and let this generation, then, make a new mark for that greatness. Let this generation of Americans set a standard of responsibility that will inspire the world.

MALE NARRATOR \#2: In your heart, you know he's right. Vote for Barry Goldwater.

"In your heart, you know he's right." The implication of the slogan is that, as extreme as some of Goldwater's positions or quotes may seem, he is merely stating uncomfortable truths that we would rather not admit.

Of course, the political ad making the greatest impact in 1964 was the so-called "Daisy" ad. The campaign aired it only once, but it was replayed and analyzed endlessly by network news broadcasts. It remains one of the most controversial ads in American political history. The subtitle of Robert Mann's book Daisy Petals and Mushroom Clouds: LBJ, Barry Goldwater and the Ad that Changed American Politics lays exclusive claim to widespread and lasting influence for a TV ad in American politics. ${ }^{4}$ Its importance is certainly not to be underestimated. It was the first ad to have become famous for news coverage of it rather than by viewers actually seeing it in the flow of everyday television programs. And it can definitely give new

3 Matthew Killmeier has my gratitude for this insight.

4 Robert Mann, Daisy Petals and Mushroom Clouds: LBJ, Barry Goldwater and the Ad that Changed American Politics (Baton Rouge, LA: LSU Press, 2011). 
meaning to the cliché "go nuclear." But "Daisy" is so hyperbolic, confrontational, and over-the-top that it can hardly be regarded as a trendsetter for campaigns to follow. It is the hard sell taken to the extreme, and the campaign immediately tried to distance itself from it. More effective and as a result more enduring as a game-changer have been the numerous soft-sell ads that employ music, as we will see beginning in 1972. Tony Schwartz, who was most influential in the ad's creation, reminds us that Goldwater was not named in the ad, or even alluded to. ${ }^{5}$ Schwartz offers this explanation in the context of how ads are meant to strengthen already-held beliefs (rather than change minds). ${ }^{6}$

What seemed to many the hysterical, angry rantings of a far right-wing lunatic morphed into the focused, organized negative Republican campaign of 1968. Musical elements in Goldwater's attack ads found their way into Richard Nixon's powerfully effective TV assault on Hubert Humphrey. In fact, music from Goldwater's "America's Image" or "Morality" would have easily fit in with music in Nixon's ads four years later. The next chapter will show how the Republican candidate was able to harness Goldwater's bombastic musical approach to negative ads to vault himself into the White House.

5 Tony Schwartz, The Responsive Chord:How Media Manipulate You-Whatyou Buy, Who You Vote For, and How You Think, $2^{\text {nd }}$ edition (Coral Gables, FL: Mango, 2017), 89.

6 This coincides with what Jim Cole said about his work on same-sex marriage in Maine in 2012. He talks about appealing to voters' already-held beliefs about fairness, justice, and a sense of "live and let live." (See Appendix 1.) 


\section{This Time Vote Like Your Whole World Depended On It: 1968}

Exceptional by any standards, 1968 was a year of instability and violent upheaval that saw many remarkable events before the November election. The war in Vietnam was not going well for the Americans; this was the year of the Battle of Khe Sanh, several village massacres by American troops (including My Lai), the Tet Offensive, the Pulitzer Prize-winning Eddie Adams photograph of the execution of Nguyễn Văn Lém, and anti-war and civil rights demonstrations in the US. Unrest was widespread. Student demonstrations took place in large cities such as Paris, Mexico City, Warsaw, and Prague. Riots became violent at the Democratic National Convention in Chicago. In one of a series of famous political debates during the Convention, William F. Buckley allowed himself to be so provoked by Gore Vidal that he called Vidal a "queer" and said that if he didn't stop calling him a "crypto-Nazi" he would "sock you in the goddamned face and you'll stay plastered." Martin Luther King, Jr. and Robert Kennedy were assassinated. There was a shootout between Black Panthers and the Oakland police. In a more violent outbreak of tensions that had been simmering for some time, "The Troubles" between Northern Ireland Protestants and Irish Catholics began.

By 1968, political ad music begins to consistently work rhetorically. Attack ads such as "The First Civil Right," "Convention," "Failure," "Vietnam," "Crime," and "Decisions" (and to a certain extent contrast ads such as "Unite," “Child's Face"), feature contemporary art music composed for orchestra, with dissonant and ametric melodies and tone clusters, jabbing sforzandos, and prominent and loud rhythmic motives in percussion. Most of the music in these ads seems of a piece, as if it were all composed to unify the campaign message, which can be described as decrying military failures in the Vietnam War and violent protests at home. Some of the ads recycle the same stock images of war, civil unrest, or poverty. Shown as text at the end of his ads, Nixon's 1968 slogan- “This time vote like your whole world depended on it"-implored voters with the same urgency as Lyndon Johnson's slogan in 1964, “The stakes are too great for you to stay home."

This is the year when a divergence of approach emerged between Democrats and Republicans to political advertising. Two television ads from the 1968 US Presidential campaign aptly characterize this divergence between Republican and Democratic party images not seen in 1964 or earlier 
campaigns. Music is the lynchpin of each ad, Nixon's "The First Civil Right" and Humphrey's "Mother and Child."

\section{The First Civil Right}

Nixon-Agnew Victory Committee 1968

Makers: Leonard Garment, Harry Treleaven, Frank Shakespeare, Eugene Jones

01:00

Presenting frightening images as well as highly dissonant music, "The First Civil Right" features Nixon himself describing the "first civil right of every American" as the right "to be free from domestic violence."

Here is a transcript of the ad:

RICHARD NIXON: It is time for an honest look at the problem of order in the United States. Dissent is a necessary ingredient of change, but in a system of government that provides for peaceful change, there is no cause that justifies resort to violence. Let us recognize that the first civil right of every American is to be free from domestic violence. So I pledge to you, we shall have order in the United States.

Ominously, Nixon intones at the end "So I pledge to you-we shall have order in the United States." This sounds as much as a threat to demonstrators as a promise to protect the public. The on-screen text at the end is: "THIS TIME VOTE LIKE YOUR WHOLE WORLD DEPENDED ON IT ... NIXON."

Music in "The First Civil Right" has a character similar to music in other Nixon ads in 1968. Yet here the music reaches a fever pitch at its most dissonant and harsh, making viewing especially unpleasant. With each musical element separate from the others, the resulting cacophony musically represents the chaos and disorder that seemed the order of the day that tumultuous year. We hear loud percussive notes on piano $\left(\mathrm{G}_{4}, \mathrm{D}_{4}\right.$, G6) at irregular as well as sporadic forte glissandi, rhythmic and pulsating snare drum cadences, a loud trumpet crescendo, a bass clarinet noodling up and down chromatically between $\mathrm{G}_{1}$ and $\mathrm{D} 2$. The music level is potted

1 Of course, the term "domestic violence" is used here in the sense of violence in the public sphere. It wasn't until spousal abuse started to be discussed more openly in the 1970s with the women's rights movement that the meaning of the term "domestic violence" began to become fixed as describing abuse between partners in an intimate relationship. 
down as Nixon begins to speak, creating an interesting effect: it seems as though Nixon is taking charge of the situation so completely that the noise volume immediately attenuates. Nixon's voice here acts as an acousmêtre, the omniscient, omnipotent narrator (see discussion of acousmêtre in the subsequent discussion of "Mother and Child"). Contributing to Nixon's quasi-mythic poetic power is the fact that when he finishes speaking, the music stops and the screen goes black. In a palpable sense, he has the last word on violence in the streets. He has vouchsafed our first civil right, the right to be "free of domestic violence."

Music here is the aural representation of the chaos depicted in the stills we see throughout. In particular, the piano figures-randomly occurring glissandi-serve to create an unsettling atmosphere of chaotic polyphony. All instruments are played in a percussive manner.

Prominent among the images are a shouting man, soldiers shooting tear gas at a crowd, a bouquet of bayonets, someone holding a revolver with military helmets and rifles in the background, a soldier with a handheld radio, a bloody man talking to another man who is being arrested by the police, fire engines battling fires in a city, a bloody man running, a rapidfire barrage of these images (increasing the tension), a building afire, other sequences, and the concluding text.

In a fascinating re-interpretation of the meaning of "civil rights" from how the term had been used for decades, Nixon posited that society being free from disorder and chaos should trump freedom from discrimination or freedom of speech, assembly, petition, and press. Nixon conveys his power to end chaos by lowering the volume of chaotic musical sounds with the power of his own voice.

\section{CASE STUDY}

"Mother and Child"

Humphrey-Muskie

Funded by Citizens for Humphrey-Muskie

Producer: Tony Schwartz

01:00

Humphrey's campaign commissioned one of the most bizarre ads in the history of television political ads, "Mother and Child." In this ad, we see a mother holding a baby and we hear a lullaby being sung by a woman. At first the music sounds diegetic - surely the mother we see on-screen must be singing the lullaby to her child. But we see in the first ten seconds 
that the mother is not singing at all. We are left with an odd impression: a disembodied female vocalist singing a lullaby, while another woman holds a baby. Strange enough - we saw a woman who we assumed was doing the singing, only to find that she is not the singer at all. Then things get even stranger: another female voice is heard, the narrator's, denouncing unspecified "violence." So we hear two women, a singer and a narrator, neither of whom is the woman on-screen with the gurgling baby. Finally, male actor E.G. Marshall narrates the ending.

This is an uncanny ad. ${ }^{2}$ Humphrey's campaign, in making ad buys for "Mother and Child," was "playing the baby card." The ad presents shots of one of the most vulnerable of US citizens, an infant, whose future, it is implied, will be in danger if Nixon is elected. So this is a domestic ad, meant to show how Humphrey is more caring than Nixon, who was widely perceived as callous and "ruthless, cynical, profane," as described in an article by NBC's John Rutherford. ${ }^{3}$ This ad seems to have targeted women, who in 1968 were still by far the most likely caretakers of children.

The text of the voice-over, focusing on worries about the child's future, might have been seen to have more credibility as spoken by a woman. Although women did not vote in greater numbers than men until $1980,{ }^{4}$ more women than men were eligible to vote from 1964 on. ${ }^{5}$

Here is the transcript:

[Woman humming lullaby]

MOTHER: He's so adorable. I wonder what it will be like when he's older.

What's going to happen to him? I hope he won't be afraid the way we are. There's so much violence now. I wouldn't be so scared if I felt they understood what it's all about, and they cared.

MALE NARRATOR: Hubert Humphrey has said that every American has the right to a decent and safe neighborhood, and on this, there can be no compromise. But for every jail that Mr. Nixon would build, Mr. Humphrey

2 One way in which Sigmund Freud defines "uncanny" is: "[O]n the one hand, it means that which is familiar and congenial, and on the other, that which is concealed and kept out of sight" (Sigmund Freud, "The Uncanny,” in Literary Theory: An Anthology, eds. Julie Rifkin and Michael Ryan [Oxford: Blackwell, 1998], 156).

3 John Rutherford, "Nixon Tapes: Ruthless, Cynical, Profane," NBC News (December 2, 2008), http://firstread.nbcnews.com/_news/2008/12/02/4429073-nixon-tapes-ruthless-cynicalprofane?lite. Accessed August 31, 2016.

4 Center for American Women and Politics (CAWP) Fact Sheet, www.cawp.rutgers.edu/ fast_facts/voters/documents/genderdiff.pdf|. Accessed July 31, 2015.

5 CAWP Fact Sheet. Accessed July 31, 2015. 
would also build a house. And for every policeman Mr. Wallace would hire, Mr. Humphrey would also hire a teacher.

[TEXT: Vote Humphrey Muskie Nov. 5th]

The song is in G Aeolian mode, seemingly a folksong and a lullaby (the mother is trying to comfort her child). The melody, hummed rubato, emphasizes the dominant, but ends on the tonic - it has a mournful and contemplative character (see Figure 5.1). Folksong has a particular effect in this ad. It almost sounds improvised, a ditty invented on the spot by a mother to soothe her infant or else a barely remembered tune the mother's mother used to sing to her when she was small. Hardly would we expect to hear instrumental music here-a Beethoven concerto, an Ellington big band piece, or a bluegrass tune-in such an intimate setting. It can only be a mother's voice singing an uncomplicated melody inartfully. Wordless singing seems appropriate music for a baby, who is not yet language-adept.

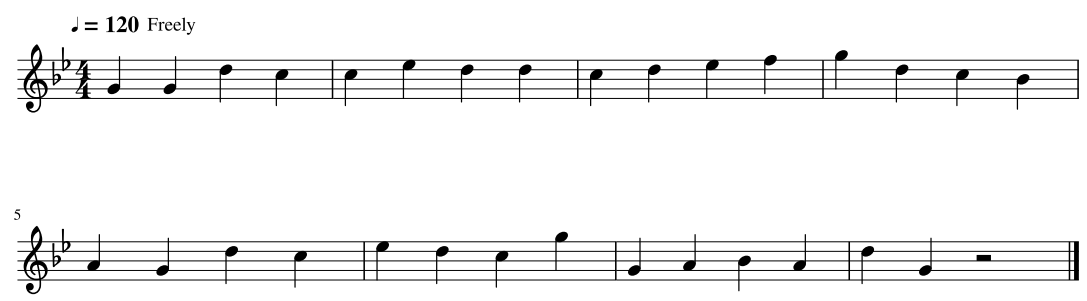

Fig. 5.1: Melody of Humphrey's "Mother and Child"

In this intimate, domestic scene, we see a lot of flesh - the mother's bare arms and a child's bare upper body. We perceive mother and child as a unit as the mother caresses her boy, illustrating Jacques Lacan's Real stage, where infant and mother are essentially one and the same person. Furthermore, the tableau in "Mother and Child" evokes religious iconography-Mary and the baby Jesus.

"Mother and Child" is unsettling on several levels. What sort of scene are we to imagine from this ad? Are we to assume that this is the inner voice of the mother? Then who is singing? Why would anyone other than the mother sing to her child? One might imagine a gathering of women getting together to discuss an uncertain future fraught with peril. We see a silent mother holding her baby, and we hear at least two other women, one presumably trying to comfort the baby with a lullaby, the other voicing the mother's 
concerns. Of course, the ad's creators hardly meant for viewers to dissect the ad and question its internal logic.

Michel Chion writes of the disembodied voice in film that he calls the acousmêtre and defines as the "richest of voice-image relations." The ad's narrator is such an acousmêtre. Chion also writes of a phenomenon that he calls "vococentrism":

If a human voice is part of [a sonic space], the ear is inevitably drawn toward it, picking it out, and structuring the perception of the whole around it. The ear attempts to analyze the sound in order to extract meaning from it—as one peels and squeezes a fruit—and always tries to localize and if possible identify the voice. ${ }^{6}$

I think that Chion is absolutely correct about this. Music is much more subversive in that the viewer pays active attention to the voice(s); music thus enters through the back door and can affect us in surprising ways. Our attempts to identify the voice in "Mother and Child" are foiled as we never learn who is speaking or singing. Acousmêtres can represent an omnipotent, omniscient, or magical figure who views the action from the outside, who sometimes will participate in the characters' lives like a deus ex machina.

The use of a male narrator at the end may be to establish authority. ${ }^{7}$ The woman expresses her fears for the baby's future, while the man closes the deal and tells us who to vote for. Democrats have long been perceived as what George Lakoff calls the "Mommy party," the party that cares about the welfare of the most vulnerable in society_children, elderly, the poor, etc. For this reason, Democratic candidates often campaign against stereotype in order to seem tough on crime, strong on defense, or uncompromising on deficit reduction. In 1968, women's voices were more likely to be heard in detergent commercials than in political ads.

A hummed lullaby (or any hummed unaccompanied monophonic melody for that matter) is sui generis in political ads. No other ads had such music. But it does seem to comport aesthetically with the ideals of the party - no nonsense, no slickness, no guile. This musical presentation almost seems intentionally anti-technology, as if technology were the cause of the troubles and threats of modern society. No electric guitars or drums, no brass choirs,

6 Michel Chion, The Voice in Cinema, trans. Claudia Gorbman (New York: Columbia University Press, 1999), 5 .

7 I thank Matthew Killmeier for this insight.

8 George Lakoff, Don't Think of an Elephant (White River Junction, VT: Chelsea Green, 2004). 
no massive orchestras-just a woman's voice. In addition, the hummed lullaby seems the best accompaniment to the baby's cooing, the only sound effect in the ad. ${ }^{9}$ The effectiveness of this ad is necessarily limited given how the music here calls attention to itself. But the ad was nothing if not memorable.

\section{Bomb \\ Citizens for Humphrey-Muskie 1968 Producer: Tony Schwartz 01:00}

With "Bomb," Humphrey was trying to employ Johnsonian tactics used against Barry Goldwater so effectively in 1964. In the ad, from oo:12, after the detonation of a nuclear device and a mushroom cloud, we hear a single drum beating a steady slow, deliberate pulse. Most evident here is economy of means. One drum struck by one mallet at regular intervals: The effect is compelling. Viewers might subconsciously associate this sign with war drums, traditionally used by Native American tribes.

The loud explosion is heard after the narrator's first line "Do you want Castro to have the bomb now?" As the ad nears its end and we hear that Humphrey wants to stop the spread of the bomb, the drum fades out to a nearly inaudible pulse. Metaphorically, it seems as though Humphrey will muffle the war drum and that he stands for peace.

A clear visual conceit in the ad is the reversal of the film to show the mushroom cloud caused by the explosion imploding on itself and then completely disappearing as if it had never happened. This bizarre reversal of the natural course of events reflects the turn the narrator's voice-over takes with "Hubert Humphrey wants to stop the spread of nuclear weapons now before it mushrooms." The narrator's final remark (accompanied by the same onscreen text), "Humphrey, there is no alterative," is hardly a ringing endorsement for the Democrat, but it mirrored the urgency of Johnson's exhortation, "The stakes are too high to stay home."

9 One ad from the Humphrey-Muskie campaign used a sound effect as its primary message. The spot opens with a close-up on the control panel on the right side of a television set. As the camera gradually pans left and downward to reveal the whole screen, we see the text "Agnew for Vice-President?" Throughout, we hear gradually increasing laughter with the off-screen viewer finally becoming so apoplectic that he breaks into a coughing fit. Agnew, Governor of Maryland at the time, was relatively unknown (a reality that changed with his 1973 plea of no contest to tax evasion charges and his resignation of the Office of Vice President). 


\section{Convention}

Nixon 1968

Makers: Leonard Garment, Harry Treleaven, Frank Shakespeare, Eugene Jones

00:45

In 1968, the Democratic Party held its national convention in Chicago amid great turmoil and strife. Earlier that year, two bright lights in the civil rights movement had been extinguished-Martin Luther King, Jr., and Robert F. Kennedy. Riots had broken out all across the country following King's assassination. The nomination of Hubert Humphrey, Vice President under Lyndon Johnson and seen by the public in 1968 as part of the establishment that was prolonging the unpopular war in Vietnam, angered many party faithful. Outside the convention venue, police clashed with anti-war protestors. Of course all of this was captured on television, causing great embarrassment to the Democratic Party. Video on the TV news alternated between war violence and domestic unrest at the convention, at universities and colleges, and in the streets.

In order to achieve maximum impact, the Nixon campaign ran this ad eight days before the election, an October surprise that Humphrey could have done without.

Editing plays a key role in the impact of this ad. We see images of Vietnam, unrest, and poverty interspersed with stills of (alternately) an earnest and determined or smiling Humphrey at the convention.

The rhetorical thrust of "Convention" is difficult to pinpoint exactly, and this fact makes the persuasion more effective. Nixon was trying to make Humphrey responsible in voters' minds for not only the Vietnam War, but also the riots at home. Using the 1968 Democratic Convention, a clear example of the contentious nature of the democratic process, the Nixon campaign implies that if the Democrats cannot manage to maintain order at their own quadrennial political meeting, how could Humphrey be expected to keep order in the streets? Together with "The First Civil Right," "Failure," "Vietnam," and other such dystopian ads, "Convention" paints a bleak picture for an American future under a Humphrey administration.

Humphrey, encapsulated in his smiling, glad-handing campaign world, seems hopelessly disconnected from events in Vietnam, where war was being waged by a fellow Democrat, President Lyndon B. Johnson, but also seems eerily disengaged from the violent confrontations that took place at the convention itself. This disconnect is apparent in the music playing in the parallel sequences. No question about it—music tells the story here. 
Not only is the ad unimaginable without music, but remove it and the ad becomes nonsensical. It comprises the ad's internal logic. At first, the music sounds festive and high-spirited, as one might imagine music to be at a political convention, but the straight, unchanged music alternates with the same music electronically distorted or with disturbing wah-wah sounds. For those paying closer attention, the title of the song played, "Hot Time in the Old Town Tonight," makes a sardonic commentary on the events portrayed and on Humphrey's complicity in them. A violent riot is indeed a "hot time."

Nixon's contempt for those protestors in the streets is clear from his nomination acceptance speech at the Republican Convention that year in Miami, where he spoke of "the great majority of Americans, the forgotten Americans, the non-shouters, the non-demonstrators." Many Americans were indeed alarmed by the level of unrest at home, and a promise to bring law and order back to America fell on eager ears.

Since Johnson had enjoyed extraordinary success in the domestic arena (Civil Rights Act of 1964, Voting Rights Act of 1965, Medicare, etc.), the Nixon campaign decided to focus on foreign policy (not hard to do as television news networks were daily broadcasting images of the war-and its protests at home-into people's living rooms). Hanging the Vietnam albatross around Humphrey's neck was not difficult. After seeing this ad, viewers are left with the impression that Humphrey is clueless and utterly disconnected from reality.

No argument per se is presented - the jarring effect of the rapidly oscillating pictures of Humphrey, interposed with disturbing images of war, civil unrest, and poverty (often with a violently shaking camera), gives a context for the unpleasantly distorted music and sounds. Voters are asked to make the connection between Humphrey and unfortunate events and situations for which he was not himself directly responsible. Even if there had been time to act following the airing of the Nixon ad, how would Humphrey have countered? It is not as though any assertions are openly made, assertions that could be refuted when they are inaccurate. Here the appeal is purely emotional and as such, it falls outside the realm of reason and logic. The only way Humphrey could have fought back would be to commission his own negative ads about Nixon, and they would have to be similarly emotional in nature in order to effectively counteract the power of the Nixon appeals. Distortion of music makes this ad unique among ads that had been created up to that time.

The strong contrast between 1968 Nixon and 1972 Nixon can be explained by his changed circumstances. As he geared up to run for 
his second term, the incumbent could run a television campaign with mostly advocacy ads reflecting his new seemingly relaxed, confident public persona. The next chapter will illustrate how Nixon turned from negative campaigning to positive ads, one of which took a page from a popular beverage company. 


\section{Nixon Now! 1972}

In 1972 "The Troubles" continued as Bloody Sunday and Bloody Friday led to antiBritish riots in Ireland. The Red Army Faction detonated bombs in Germany. African American Congresswoman Shirley Chisholm ran for President. Nixon took his goodwill tour of China and signed the first Strategic Arms Limitation Treaty. Military operations continued in Vietnam; Kissinger visited South Vietnam and said, "Peace is at hand." Jane Fonda toured North Vietnam and a photo of a Vietnamese boy burned with napalm running down the street became well-known and earned the photographer a Pulitzer Prize. At the Olympic Games in Munich, eleven members of the Israeli team were taken hostage and ultimately killed by Palestinians in what came to be known as the Munich Massacre. Congress voted to send the Equal Rights Amendment to the states for ratification. Financial derivatives were first sold on the Chicago Mercantile Exchange. The Godfather premiered. Comedian George Carlin was arrested for obscenity. Bobby Fischer defeated Boris Spassky to become world chess champion. In early June, arrests were made for the Watergate break-in that would eventually lead to Nixon's downfall.

As the 1972 general election approached, there was an incumbent President who, while he had to deal with falling popularity numbers and various challenges at home and abroad, enjoyed an enormous advantage over his challenger. Richard Nixon was that incumbent, and George McGovern had been nominated to challenge him with a Democratic anti-war message. The progressive wing in the Democratic Party had been furious in 1968 when the establishment candidate Hubert Humphrey was installed as the nominee by party insiders, and this was a chief cause of the riots at the Democratic Convention in Chicago. Four years later, they got the candidate they wanted in McGovern. Adored by the left, McGovern turned out to be too progressive for the American electorate at that time, and he was overwhelmingly defeated in November, only winning Massachusetts and the District of Columbia. In the end, Nixon's election had been more or less a foregone conclusion. Not everyone expected a cakewalk, though: Peter Dailey, leader of the November Group tasked with getting Nixon re-elected, was quoted as saying that he expected "a squeaker that would go down to the wire."

In the 1970s, commercial messages were appearing in new places, where ads had not been previously presented, such as on public transit and at the 
cinema. ${ }^{2}$ These ads were examples of the "soft sell" approach to advertising - more style than substance. By the 1970s, television commercials as well had all but given up discussing the relative merits of their products or services and instead focused on mood and aesthetic style. This style of advertising was advocated and practiced by DDB and continues to the present day; it has largely supplanted the "hard sell" of Rosser Reeves. Nixon's soft sell is embodied by "Nixon Now."

\section{CASE STUDY \\ Nixon Now \\ Nixon-Agnew \\ Committee to Re-Elect the President \\ Producer: November Group, Billy Davis \\ 02:13}

With this ad produced by Billy Davis and the November Group, Richard Nixon's campaign, in a revolutionary move, tapped into the commercial style of Coca-Cola's 1971 ad "Hilltop song," "I'd Like to Buy the World a Coke." Both ads feature crowds of young people and choral singing. Both suggest the innocence of youth who seek progress and have hope for the future. "Nixon Now" seems to indirectly draw on the popularity of Coke among young people.

"I'd Like to Buy the World a Coke," the centerpiece song of the ad, has become an iconic bit of advertisement. While laying over in an airport in January 1971, McCann-Erickson advertising executive Bill Backer thought up the song for the firm's client Coca-Cola. So popular was the music in "Hilltop song" that the composer decided to change the lyrics to convert the jingle into a pop song. In February, records of the song were sent around to American radio stations.

"Nixon Now" first aired in July 1971. With ads like this, Nixon hoped to make the youthful impression with which Kennedy had beaten him twelve years previously. These spots were intended to appeal to youth more than McGovern's ads, which focus more on issues than on style and which lack music. Whereas the Democratic contender seems concerned or upset in many of his spots, Nixon looks as though he is enjoying himself in all of the sequences.

2 Thomas Borstelmann, The 1970s: A New Global History from Civil Rights to Economic Inequality (Princeton: Princeton University Press, 2012), 299. 
The ad's lack of specifics and its feel-good aesthetic was to characterize many advocacy ads in subsequent decades. None of Nixon's previous accomplishments are discussed, nor is there any mention of how he was addressing domestic and foreign challenges facing his administration. Instead, the viewer is barraged with a series of positive images and sequences. The first images we see are of a butterfly resting on a flower, a bird with the sun in the background, dandelion spores in the sun, a red barn with flowers in the foreground, a frosty landscape, and daisies in the grass. One might well ask why these pictures would appear in a political advertisement, what information necessary for voters do they convey?

Adding lyrics to the images contributes little of substance to the ad. Arguments in the song text are equally oblique. In fact, there is only one passing reference to Nixon's successful visits to China and the Soviet Union: "Reaching out / Across the sea, Making friends where / Foes used to be, Giving hope / To humanity." No direct mention is made of Nixon's environmental successes including the establishment of the EPA, the signing of a nuclear arms treaty, a balanced budget, or of doing much to end segregation in the South. If, instead of "Nixon Now," the singers sang "Mickey Mouse," the meaning of the ad would change but little!

In effect, the "Nixon Now" ad seems to have been a precursor to the Morning in America ads that appeared twelve years later (to be discussed in Chapter 9). Its positive orientation, creating an upbeat impression for life under the incumbent President, its "good feeling" music written specifically for the ad, its virtual lack of mention of specific accomplishments, its cascade of pictures of satisfied and happy people. This is the type of ad that is produced for a candidate who feels that his position is secure so he does not have to make a case for himself. Paradoxically, he appealed to youth more as an older politico, where his self-confidence replaced his nervous and skittish younger self. Indeed, the smiling, self-assured president almost seemed younger than he did during his "Checkers" speech, delivered twenty years earlier. Despite its potential appeal for younger voters, the music in "Nixon Now" would hardly offend or annoy older voters.

The slogan "Nixon Now" almost sounds like a moral imperative. "More than ever, Nixon now" seems a demand from youth for a much-needed change of leadership — as such it might seem better suited to the challenger McGovern than to the incumbent.

Adlai Stevenson's admonishment about selling candidates like breakfast cereal being detrimental to the democratic process seems painfully evident in this ad. Indeed, if some of the images and text were switched, this could easily work as a spot for a popular breakfast cereal. Even the opening 
images of nature could seem to imply the wholesomeness of the grains in the cereal.

Of the importance of the Hilltop ad, Thomas Frank writes:

Oddly enough, at the same time, Coca-Cola was offering a theoretically identical campaign, organized around the authenticity-grabbing declaration that "It's the Real Thing" and a popular folk-rock jingle that proclaimed multicultural harmony; peace and love under the aegis of the universal product. ${ }^{3}$

Perhaps the November Group, consisting of advertising executives from Los Angeles and New York particularly selected by the Nixon campaign, ${ }^{4}$ hoped to associate that slogan with the President. One can imagine fancifully various campaign slogans such as "Nixon's the Real Thing" or "Things Go Better with Nixon." The "multicultural harmony" and "peace and love under the aegis of the universal product" of which Frank writes are consistent with the intended appeal of "Nixon Now." Older generations were already considered by campaign operatives as "in the bag" for Nixon in large majorities; this ad shows young people seemingly united with their elders behind an irresistible leader. What's more, the ad seems to capture the spirit of demonstration and citizen action that characterized the unrest of the late 1960 so abhorred by Nixon.

The melody is catchy and highly repetitive (see Figure 6.1), intended to embed itself firmly in viewers' minds for continuous replay throughout the day, just like the Kennedy jingle of 196o. After an exposure or two to the ad, viewers' minds take over, doing the campaign's work for them. Such an ad would scarcely convert a staunch Democrat to the cause, but undecided (low involvement) voters might be influenced to vote for the embodiment of Nixon shown in the ad.

Of chief importance is the singability of the song. The mostly pentatonic melody's ambitus spans only a major sixth, from a low point of $E$ to a high point of $C \# .{ }^{5}$ Because the song is so well-crafted, viewers come away hearing it in their heads or even humming it. Its singability allows them to actually sing, thereby even more firmly fixing the song in their consciousness. Even

3 Thomas Frank, The Conquest of Cool: Business Culture, Counterculture, and the Rise of Hip Consumerism (Chicago: University of Chicago Press, 1997), 179.

4 Edwin Diamond, "The City Politic: November Song," 8.

5 Remarks about particular notes and chords in Nixon Now pertain to the first section in A major; they apply equally in transposition in the subsequent sections in $\mathrm{Bb}$ and $\mathrm{B}$. 

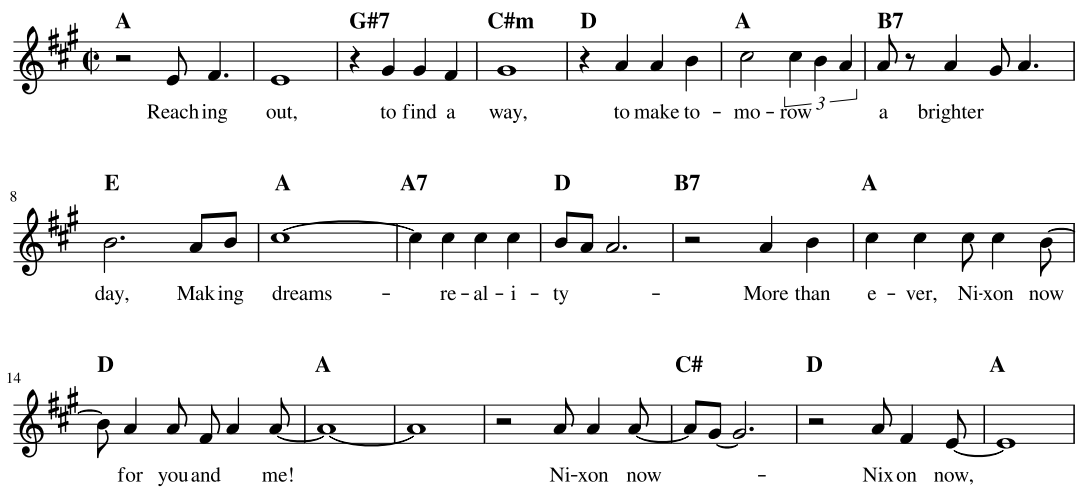

$\begin{array}{lll}\text { B7 } & \text { E } & \text { A }\end{array}$
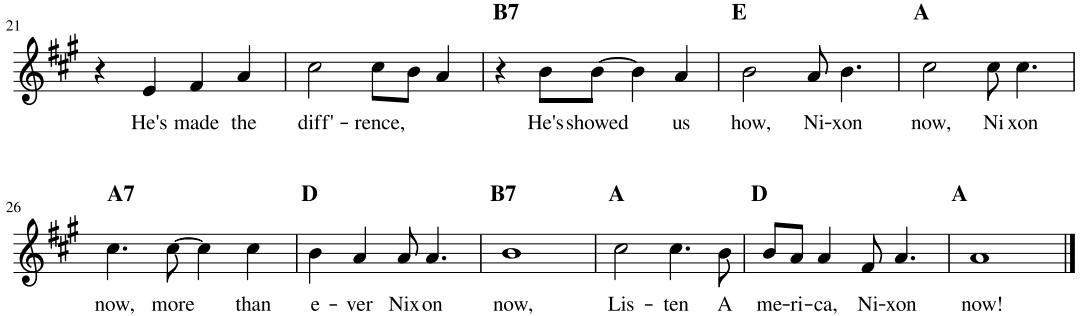

Fig. 6.1: Verse and chorus of "Nixon Now!"

alliteration of the repeated iterations of "Nixon Now" adds to the catchiness and memorability of the ad.

Gradually rising from $\mathrm{E}$ to $\mathrm{C} \#$, the verse's first half could imply progress and upward dynamism. The second half of the verse descends from $\mathrm{C} \#$ down to the tonic A, giving the verse's end a closed off arrival point. Flat-side chords ( bVII, IV) and modal progressions (II-I) imbue the ad with a folksy atmosphere and lend Nixon a certain softness. Slide guitar and tambourine give timbral support to this softness.

The final chords of the song, highlighted by a prominent ritardando, are IV-I, a plagal cadence often heard in the "Amen" at the end of Christian hymns. This particular cadence can seem to imply "Amen" to Nixon's candidacy, to inject an air of inevitability to Nixon's re-election. Plagal cadences are also evident in "Hilltop song." Music in "Nixon Now" is vocal, and not just vocal, but also choral, giving the effect that the people in the ad are singing together. Mixed choral polyphony lends a communal aspect to the ad. Certain harmonic elements stand out from the texture: $\mathrm{C} \#$ major (III) in the chorus (foreshadowed by the tonicization of $\mathrm{C} \#$ minor at the beginning of the verse) as well as G major (bVII). Some rhythmic 
elements call attention to themselves as well, such as the syncopated accent on "MORE than ever ..." in the chorus and syncopated "Ni-XON now." Instruments in the ad include electric bass, electric guitar, slide guitar, drums, and tambourine.

The harmony is firmly tonal (though with modal borrowing), initially in A major, then twice transposed up a semitone. Modulations by semitone energize the message. Further, the rising modulations, together with the gradually rising melody, suggest constant, unending progress, in a kind of corkscrew effect. This type of modulation has become so widespread in popular music that it has become cliché. ${ }^{6}$

$\begin{array}{ll}\text { 00:00-01:15 } & \text { A major } \\ \text { 1:16-1:36 } & \text { B b major } \\ \text { 1:37-2:13 } & \text { B major }\end{array}$

"Hilltop" exhibits a strong connection between popular music ("I'd like to teach the world to sing [in perfect harmony]") and capitalism ("I'd like to buy the world a Coke"), the type of connection about which Timothy Taylor has written so compellingly. ${ }^{7}$ More broadly, Nixon's campaign, by tapping into this clearly fertile marriage of popular culture and commercialism, was able with this ad to co-opt and use its enemies' imagery and symbolism against them, because by 1972, many of these things had become mainstream.

6 A website called TV Tropes calls this harmonic move a “Truck Driver's Gear Change.” They describe it thus: "The Truck Driver's Gear Change is a modulation near the end of a song, shifting upwards by some relatively small pitch increment - usually by one semitone (half step) or whole tone (whole step), but occasionally by other intervals. [...] The term was apparently coined by this site, which compares the technique to a tired, overworked truck driver performing an unartistic, mechanical function. [...] This is about 'shifting gears' for what is arguably called 'dramatic effect' but what has devolved into a musical cliché: sliding up a step and remaining there for the rest of the song," “Truck Driver's Gear Change," TV Tropes, http://tvtropes.org/pmwiki/pmwiki.php/ Main/TruckDriversGearChange. Accessed August 29, 2016. Key relations between the tonic and the key a semitone higher occupied a much different space in the common practice period. In the Baroque, the Neapolitan chord (as b II is referred to in music theory) was a fairly common chord at cadences in pieces written in minor keys. By the Romantic era, b II had become a discrete harmonic plane. Its prominence for example in Franz Schubert's String Quintet In C Major, D. 956 (1828), where the $\mathrm{D} b$ occupies large amounts of tonal space and operates in opposition to the tonic $\mathrm{C}$, has led to some fascinating musicological interpretations of meaning in the piece. But as stated above, this is different from the semitone modulation (often repeated) in popular music or commercials.

7 Timothy D. Taylor, The Sounds of Capitalism:Advertising, Music, and the Conquest of Culture (Chicago: University of Chicago Press, 2012). 
Lyrics in "Hilltop" speak of an altruistic desire to allow others to experience something together (albeit through capitalist means). The centrifugal impulse of "I'd Like to Buy the World a Coke" is reflected as well in "Nixon Now," which also has a communal aspect with lyrics like "He's showed [sic] us how" and "More than ever, Nixon now for you and me."

Given the self-centered focus on personal individual satisfaction that has characterized commercials since the 1980 s, these types of group "we're in this together" feelings seem somewhat alien to twenty-first-century viewers. But "Nixon Now" contrasts just as starkly with political ads that preceded it. No television political ads in the 1950s or 196os are in the style of a popular song contemporarily heard on the radio.

Here is the transcript of the ad:

MEN (singing):

Reaching out

To find the way,

To make tomorrow

A brighter day,

Making dreams

Reality,

More than ever, Nixon now

For you and me.

MEN AND WOMEN (singing):

Nixon now, Nixon now.

He's made the difference,

He's showed us how.

Nixon now, Nixon now.

More than ever, Nixon now.

Listen America, Nixon now.

WOMEN (singing):

Reaching out

Across the sea,

Making friends where

Foes used to be,

Giving hope

To humanity.

MEN AND WOMEN (singing):

More than ever, Nixon now

For you and me.

Nixon now, Nixon now. 
He's made the difference,

He's showed us how.

Nixon now, Nixon now,

More than ever, Nixon now.

Listen, America, Nixon now.

Nixon now, Nixon now.

He's made the difference,

He's showed us how.

Nixon now, Nixon now,

More than ever, Nixon now.

Nixon now, Nixon now.

Listen, America, Nixon now.

Nixon's name is mentioned 22 times in the ad.

\section{Russia}

\section{Committee to Re-Elect the President}

04:20

Another one of the "good feeling" ads for Nixon in 1972 was "Russia," produced by the Committee to Re-Elect the President. "Russia" is a semiotically complex ad that cannot be treated fully in the limited space here, but we can examine its most salient features. The ad starts with the camera panning down from the red star (a symbol of communism) atop St. Basil's Cathedral in Moscow. Then we see a short clip of the President's motorcade driving through Moscow's streets, followed by a series of scenes of Nixon and Henry Kissinger (his Secretary of State) interacting with Russian diplomats, including both formal and informal meetings. During this sequence, we hear orchestral music in D minor — soulful and melancholy, while also dignified and refined. This particular piece, apparently a simulacrum of Russian folk music, is the most intriguing music in the ad (see Figure 6.2).

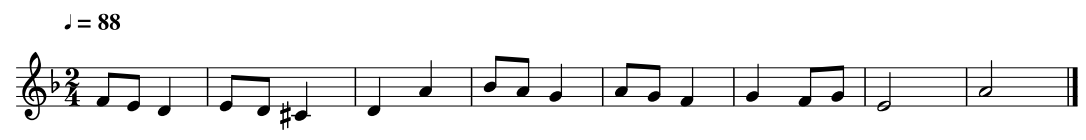

Fig. 6.2: "Folk song" from Nixon's "Russia" 
Next, Nixon is in a television studio, recording a live broadcast to the Soviet people. As his speech continues, we see scenes of Nixon and Breznev at a signing ceremony, and various scenes of Nixon speaking with his delegation. While the speech still continues and we see numerous pictures of smiling Russian citizens, then ballet dancers, a wedding procession, tourists taking photos in Red Square, Olympic sprinters, more ballet dancers, a children's chorus singing, and more pictures of Russian citizens, the music transitions to Piotr Tchaikovsky's Swan Lake. Later we hear funereal band music as Nixon places a wreath in memory of victims of the Siege of Leningrad.

Primarily through music, "Russia" humanized the Soviets, so that Americans could see themselves as more similar to their feared rivals than different. The ad highlights Nixon's foreign policy experience with a "strength through diplomacy" appeal.

The unidentified orchestral piece at the beginning is the most intriguing music in the ad, because it seems to have nothing at all to do with Russia or the Soviet Union. I myself did not recognize this epic, monumental music and tried to determine its origin. Having asked numerous experts on Soviet and Russian music whether they know the tune, ${ }^{8}$ I must conclude that this is a simulacrum of Russian folk music. The initial iteration of this music stops at 00:31, just as an excerpt from Nixon's television address to the Soviet people begins. At 00:57, after Nixon's words "limitation of nuclear strategic arms," the music recommences, this time softer, with a flute playing the theme.

Next played, as Nixon continues his address, is Tchaikovsky's Swan Lake, which was music familiar to most Americans, and it helped to situate the USSR - most often thought of in the United States at the time as a military power whose purpose was to propagate Communism around the world-as an idyllic, fairytale Russia, a synecdoche for the entire nation of diverse cultures and peoples. Further, ballet music depicts the Russians as a highly civilized people, proud of their culture.

Then, as the music changes to nondescript orchestral music, Nixon and his wife Pat tour the ancient residence of the czars in Leningrad and St. Sofia Cathedral in Kiev; then we see Pat Nixon with the Russian Circus, shaking a bear's paw. As the scene shifts to Nixon at the Leningrad Piskarev Cemetery (where Nixon was commemorating with Soviet officials the Siege

8 Scholars of Russian music whom I consulted include Olga Manulkina, Marina FrolovaWalker, Dmitri N. Smirnov, John Riley, Pauline Fairclough, Gerard McBurney, and Richard Taruskin. None of them could identify the piece. 
of Leningrad), and during the live television broadcast (talking about his experiences at the cemetery), we hear funereal band music. Following this, we see a solemn procession for the laying of the wreath, alternating with a picture of "Tanya" as Nixon quotes from her diary, which recounts the deaths of her family members during World War II.

Finally, we hear the national anthem of the Soviet Union, conveying majesty and pomp. Americans were familiar with this anthem most recently from the 1972 Olympics, which had taken place in Munich in August and September, and in which the Soviet Union had the highest medal count. ${ }^{9}$ As the music transitions to the Soviet national anthem, we again see pictures of Russian people in various group settings. Then, as the anthem continues, Nixon is again addressing the Russian people and says, "спасибо и до свидания," which the narrator then translates: "Thank you and goodbye." Next, there is a cut to a crowd, and the camera zooms in on some people waving both Soviet and American flags; then we see Nixon and his wife waving to the crowd before they board their plane. As the anthem fades out, the screen fades to black and we see white text: "President Nixon. Now more than ever. The preceding was a recorded announcement paid for by the Finance Committee to Re-elect the President."

In general, this ad had some clearly positive traits, chief among which is that it humanized the Soviets, so that Americans could see themselves as more similar to their feared rivals than different. In fact, music does the heavy lifting in humanizing them; the images and voice-over support the music. "Russia" is clearly a product of its time. Such an ad would have been unimaginable a decade earlier, during the tense standoff between Kennedy and Khrushchev that was the Cuban Missile Crisis, or a decade later during the so-called War of Words in Reagan's first term, when the term "Evil Empire" was in currency. ${ }^{10}$

9 The USSR was much on the minds of American sport fans after the 1972 Games. A controversial series of decisions by officials at the end of an intense game allowed the USSR to erase the US lead in the final in men's basketball. The controversy was so great, in fact, that the US team refused to stand on the medal platform and accept silver medals.

10 Sting felt the need to re-humanize the Soviets in 1985 with his song "Russians" (which also used Russian music, a theme from Lieutenant Kije by Sergei Prokofiev). 


\section{Russia Response \\ McGovern 1972 \\ Maker: Tony Schwartz \\ 01:00}

The Democrats' tendency to eschew music in their political ads, seemingly in an effort to keep the tone serious and focused on a logical and rational appeal, is evident in "Russia Response." This ad takes this attitude to the extreme: not only is "Russia Response" devoid of music, there are no sound effects or even images, except for a black screen with scrolling white text. This ad is a direct rejoinder to the Nixon "Russia" ad, which, in contrast to "Russia Response," used a lot of music.

The 1972 Nixon campaign wanted to show that the status quo should be maintained, so their ads chiefly emphasized Nixon's foreign policy accomplishments and had a general "feel good" aspect, which music created and images and text supported. Nixon was not trying to get people to listen carefully to a message of change; he wanted with his advertising campaign to merely maintain his momentum. McGovern, on the other hand, was desperate for people to place their trust in an earnest Senator from South Dakota. McGovern's sober attack ad in black-and-white to Nixon's colorful and musical advocacy ad.

In addition, McGovern was unable to benefit from the scandal caused by the June 1972 Watergate break-in, because connections between the Nixon administration, the Committee to Re-Elect the President (CREEP), and the break-in had yet to be fully investigated, let alone made public. Finally, the McGovern campaign had its own problems going into the election. Journalists had revealed that Thomas Eagleton, McGovern's initial choice for running mate, was found to have spent time in mental facilities, even receiving shock treatment. Even today there is still a stigma attached to mental illness, but in the 1970 s, such a revelation was virtually a surefire career-killer. In part due to McGovern's choice of running mate but also for other reasons, Democrats were widely seen by the American public as incompetent and lacking judgment.

Musical silence roars in “Russia Response." Viewers familiar with Nixon's "Russia" would likely recall the prominent Russian music the ad featured, which makes music's absence in the McGovern ad all the more striking. Regression to black-and-white, along with the lack of music, made the ad stand out among other colorful and dynamic ads and the TV programs it sponsored. But responding to Nixon's emotional persuasion with rational arguments (however carefully constructed) was a doomed enterprise to start with. Nixon's appeal to emotion won the day. 


\section{Nixon the Man \\ Committee to Re-Elect the President \\ Maker: The November Group \\ 04:20}

Chiefly because it wants to deny its origins and in some cases even its existence at all, political ad music is rarely diegetic. Typically, music plays underneath as a kind of covert underscoring to the ad's more overt message. Even rarer are sequences of candidates playing instruments themselves. In "Nixon the Man," however, we have two examples of diegetic music: Nixon himself playing piano and some wedding music. In the second scene of the ad, which is actually the first scene following the narrator's introduction, Nixon is shown playing "Happy Birthday" on the piano to great applause. And "Happy Birthday" not just to anyone, but to Duke Ellington, of all people!

Showing the President playing piano in a moment of levity casts a positive light on him as a well-rounded individual, a guy who likes to have a good time in addition to being competent at his job. The first joke that Nixon cracks seems genuinely self-effacing as he delivers it: as he takes the floor after Ellington has left the stage, he says, "Now ladies and gentlemen ... [pause, audience laughter] please don't go away!” His joke is funny not only because it is well-delivered, but also because of the incongruity of the notion that people in the audience would be inclined to leave the venue because the President had stepped up to the microphone.

Music in this ad therefore serves a quite different purpose than the nondiegetic music heard in most ads. Instead of creating a particular mood, this music fulfills a metadiscursive function - the content or form of the music. It is almost unimportant what type of music Nixon plays; it only matters that he plays (although playing "Happy Birthday" shows him as the life of the party more than playing a Debussy prelude or a Bach invention would).

An ability to play piano can be a marker of class. A family that can afford a piano, lessons to learn how to play it, and time to practice is a middle- to upper-class family. Further, a piano is a specific cultural artifact representing Western high culture. As opposed to a diddley bow, banjo, or bongo drum, a piano is the instrument a man wearing a dinner jacket would play. This introductory segment to the ad shows the president with a specific skill that many people wish they had, but it also presents him as a humble and gracious host who is on friendly terms with a music legend.

The ad starts quietly, with Nixon working in the Oval Office, as the narrator says, "In this film, we can glimpse the private man, at work and 
in his relaxed moments the man so few people know." Then, we see him grinning and shaking hands with Duke Ellington, talking to the crowd, and subsequently praising Ellington before playing "Happy Birthday" at the piano. Nixon says, "Duke Ellington is ageless, but would you all stand and sing Happy Birthday to him and please in the key of G?" Nixon plays, and the guests sing.

Next, we see Nixon conferring seriously with John Ehrlichman, counsel and Assistant to the President for Domestic Affairs. Nixon is taking a strong stand about keeping property taxes low. After that are sequences from his daughter Patricia's wedding to Edward Cox in the White House Rose Garden in June 1971. ${ }^{11}$ As Nixon walks Tricia down the stairs and towards the altar, we hear Jeremiah Clarke's Prince of Denmark's March. (Popular among actual British royalty as well, the same piece was used for the wedding of Lady Diana Spencer to Prince Charles a decade later.) Tricia's wedding does seem almost royal in its pomp and majesty. Of course, this processional music, along with the music to which Nixon takes his father-daughter wedding dance and then dances with his wife, is also diegetic, even though we cannot see its source. Following the wedding, there is a scene without music of Nixon speaking on the telephone about the necessity of Secretary of Treasury John Connally following through on a planned diplomatic trip to Latin America.

The last scene again features a lighter moment. The President is thanking his Chinese translator and jokingly suggesting that he checked the translations and found that "she got every word right," whereupon the audience breaks into uproarious laughter. Of course it is funny because unlike President Hoover, who was fluent, Nixon spoke no Chinese whatsoever. Again Nixon employs self-deprecating humor to endear himself to his audience, and to great effect. The Chinese clearly love this guy.

Finally, the narrator-the acousmetre-reasserts his presence and resets the frame that opened the ad when he says "Richard Nixon, a man of compassion, courage, and conscience, a man America needs, now more than ever" as we see a black screen with the white text "President Nixon. Now more than ever. The preceding tape paid for by the Television Committee to Re-elect the President."

In successive scenes, "Nixon the Man" presents Nixon as:

1. hardworking

2. musical, talented, socially adroit, possessed of a fine sense of humor

11 Life, June 18, 1971, as quoted in Will Swift, Pat and Dick: The Nixons, An Intimate Portrait of a Marriage (New York: Simon and Schuster, 2014), 274. 
3. serious and committed to limited government

4. a family man and loving father

5. adept in foreign affairs, down-to-earth, practical

6. loved internationally by a people many Americans find inscrutable

Nixon, as the incumbent President, is afforded the opportunity to enjoy happy and adoring crowds. He had the luxury of appearing comfortable-casual, even-in his role as President. McGovern did not have the benefit of presenting himself as a relaxed incumbent. He could only show himself talking with angry workers, disenchanted with the status quo. With "Nixon the Man," we feel as though we are granted VIP status and entrance into the President's inner circle. Of course, what seems like an intimate meeting between a President and a close, trusted adviser is actually a carefully constructed photo opportunity. How could an entire television crew not make a President a bit self-conscious, knowing that this spot will be broadcast to millions of people? Scenes from this ad show Nixon almost exclusively not in his private moments, but rather in his public persona as head of state. Even his daughter's wedding with Secret Service all around was hardly a private moment.

Nixon's plain, direct language in the phone conversation with an unidentified aide makes the President look like an average guy-the type of person Americans favor in that position. Also, his practical, hard-headed political calculations that characterize his statements reflect the "common sense approach" many Americans value in their political leaders. Largely successfully, this ad aims to present Nixon as compassionate, courageous, and conscientious, as the narrator states at the end of the ad. "Nixon the Man" was meant to contrast with some people's perceptions of Nixon as short-tempered, arrogant, boorish, and petty, as he appeared in some contexts (and as he would later emerge in the Watergate tapes).

Viewers hoping for a more voyeuristic peephole into his personal life, given how the narrator introduced the ad and its significance, would be disappointed. We are promised insight into the private man, but with this ad we are still seeing the public man. Even an apparently private consultation with a trusted adviser becomes on examination a performance of a fashion. When Nixon is conferring with John Ehrlichman, we watch the scene unfold from two camera views. One is an over-the-shoulder view of Ehrlichman, and the other is a close-up of Nixon. So this encounter, a conferral about a matter of domestic policy, is not just a casual moment caught on tape, but rather a well-planned film opportunity with two camera vantage points. The same is true for the phone conversation. We see a view of Nixon through 
a window, a close-up of Nixon (in a slightly low angle, giving Nixon an air of authority), and a cut-in extreme closeup of his left hand, fiddling with the telephone cord, with a pan back to the President.

The overall aspect of this ad is cinematic. This scene only seems natural to us because we are used to cuts from watching films, but it is artifice, a constructed visual narrative.

\section{McGovern Defense \\ Democrats for Nixon 1972 \\ Maker: The November Group 01:00}

Commissioned by Democrats for Nixon, a group headed by Nixon's former Treasury Secretary John Connally, "McGovern Defense” was a powerful piece of propaganda. I like to imagine an adman pitching his idea for an ad that he was calling "McGovern Defense": "We will need to buy plastic soldiers, sailors, and airmen and some military planes, destroyers, and aircraft carriers - there is a Toys ' $R$ ' Us just down the street. Or you know what? My son has these toys, I'll bring 'em in tomorrow. Then we can arrange them in groups, and in a series of scenes someone will take away a part from each group as the narrator announces how McGovern wants to reduce military personnel and equipment. It'll be great!" The idea seems nonsensical, yet it worked wonders. "McGovern Defense" devastated by its sheer simplicity. Having worked in advertising himself, H. R. Haldeman (a top aide who was later implicated in Watergate and served time in prison) was in charge of Nixon's advertising campaign.

Music infuses this ad with a serious tone that transforms the absurd imagery into a compelling emotional appeal. This controversial, negative ad begins with a snare drum roll, and then the snare continues playing a marching cadence, and a bass drum joins in. The overall effect is highly dramatic. Drums continue as the narrator announces the cuts McGovern would make, and the hand gradually takes away the military units. At twenty-eight seconds, as the narrator says "... and carriers from sixteen to six," there is a crescendoing cymbal roll lasting about five seconds, which highlights Senator Hubert Humphrey's quote to follow: “It isn't just cutting into the fat. It isn't just cutting into manpower. It's cutting into the very security of this country." Humphrey's quote is read as the camera pans over the piled up removed military units, which look like postwar carnage. Then, forty-five seconds into the minute-long ad, we hear "Hail to the Chief" 
and see positive pictures of Nixon, implying that voters can relax and stop worrying about national defense as long as they make the proper choice by voting for Nixon.

"McGovern Defense" makes use of a common strategy for political adsit creates a problem with the opponent and then provides a convenient solution in the form of the candidate. Anger about continued American involvement in the Vietnam War buoyed McGovern's campaign, and he promised to pull American forces out and significantly reduce military spending. Nixon used this commitment as a cudgel with which to beat his opponent throughout the campaign. In the ad, McGovern's proposals to cut military spending are depicted simply and directly, with toy servicemen and military transport units. Using toys was a brilliant move, because it implied, without stating it outright, that McGovern perceived the military in a simplistic way and was unfit to be Commander-in-Chief. "Our military is not to be trifled with as a child manipulates his toys," the ad seems to say. In addition, this visual aid makes evident the extent of the cuts that the ad alleges McGovern to have favored. Viewers are expected to make the mental leap between a reduced military force and vulnerability to military threats around the world.

Percussive march cadences keep the focus on the military. The strong contrast between the sparse snare, bass drum, and cymbal to the full orchestral rendition of "Hail to Chief" is clear. "Hail to the Chief" reminds voters that Nixon has been President during the previous four years and currently sits in the White House. Nixon appears "presidential" and in charge as he talks with Navy officers. We feel that our trust in him is not misplaced. Directly following the questions raised about McGovern's fitness as Commander-in-Chief, we are provided with an answer: Nixon. The text "Democrats for Nixon" puts a full stop to the ad, implying that Nixon is so clearly the superior candidate that even voters with a different worldview are flocking to him.

\section{Young Vets}

McGovern 1972

\section{Producer: Charles Guggenheim}

"Young Vets" is an incredibly hard-hitting anti-war ad that harshly criticizes the treatment of paraplegic Vietnam veterans. Incontinence and the inability to sire a child, both results of combat injuries, were among the topics discussed. Some voters were likely unhappy to see such matters 
mentioned on television with such candor by former soldiers, sailors, and airmen seriously wounded in service to their country. Rather than confront uncomfortable truths about a war waged on foreign soil with questionable values for the interests of the US, people wanted to relax and unwind in front of the TV after a hard day's work.

"Young Vets" of course used no music - it would be difficult to imagine any appropriate music to accompany the frank (and seemingly unrehearsed) discussion going on. Any music in the background would have distracted from the veterans' and McGovern's remarks and would have been perceived as trivializing the moment or would have been seen politically as exploitative (dolorous dirge music). Charles Guggenheim, McGovern's ad maker, said, "We believe in advocacy. Let someone else do the name calling. We don't want the campaign to degenerate into a pissing match." ${ }^{{ }^{2}}$

As we will see in the next chapter, the use of music in political ads becomes less important and less effective. This lull will be followed two election cycles later by some of the most powerful emotional appeals through music in US political history. But first, we must discuss 1976. 


\section{A Leader, For a Change: 1976}

In 1976, the trial of the Red Army Faction started. The first commercial flight of the Concorde took place. Independence was declared in Western Sahara, but the US vetoed a UN Resolution declaring Palestine to be an independent nation. Black high school students in Soweto rose up in protest to the use of Afrikaans as a required language of instruction. Steve Wozniak and Steve Jobs founded Apple Computer. The United States of America celebrated its bicentennial. In a debate in San Francisco, Gerald R. Ford, incumbent Republican President committed a gaffe when he said, "There is no Soviet domination of Eastern Europe."

Neither of the candidates in 1976 had been elected President before. The sitting President lacked enthusiastic support from his party establishment and was associated in voters' minds with the Watergate scandal, coverage of which millions of voters had watched with a mixture of fascination, disgust, and other emotions. Carter famously said during his campaign that he would never lie to the American people. Probity and honor loomed large as voter priorities. Ford was not perceived as dishonest or corrupt himself, but he could not escape the taint of his association with Nixon. It also did not help that he had been weakened in the primary by a surprisingly powerful challenge from Ronald Reagan. In a close election the challenger, a former state governor won. Seventy percent of Carter's attack ads in 1976 addressed policy differences with Ford (as opposed to only thirty-two percent against Reagan in 1980). ${ }^{1}$

Political ads on TV were, by 1976, largely thirty-second affairs, with the longer bios and in-depth presentations of candidates gradually becoming extinct. ${ }^{2}$ Music, where it is present in political ads from 1976, is used inartfully. Production quality, including editing, also leaves a lot to be desired. Music did not play as important a role in this election as it had before or would in subsequent elections. Where it is used, it is mostly as a type of aural filler. Nevertheless, there were some musical aspects that contributed to shaping voter perceptions of the candidates. There seems no clear explanation for why music is so ineffectively deployed in this and the next election cycle.

1 Kathleen Hall Jamieson, Everything You Think You Know About Politics ... and Why You're Wrong (New York: Basic, 2000), 106.

2 Montague Kern, 3o-Second Politics: Political Advertising in the Eighties (New York: Praeger, 1989), 4 . 


\section{Peace}

\section{President Ford Committee 1976 Maker: Bailey, Deardourff and Associates 01:00}

"Peace" featured cloying music similar to that often heard in commercials for products. Bailey, Deardourff and Associates produced the ad, which was paid for by the President Ford Committee. The firm worked for many Republican candidates of a moderate or progressive bent, participating in over seventy campaigns, both primary and general, and thanks to Bailey, Deardourff and Associates, Ford was able to close the gap in the months leading up to Election Day, in the end making it a closer election than it otherwise would have been. ${ }^{3}$

Lyrics for "Peace" are:

There's a change that's come over America,

a change that's great to see.

We're living here in peace again, we're going back to work again, its better than it used to be.

I'm feeling good about America, and I'm feeling ...

Without overtly mentioning the Vietnam War, the ad trumpeted the conflict's end as one of the Ford administration's chief accomplishments. In addition, the lyrics implied that the economy was improving. But although Ford had inherited a troubled economy from the previous administration, his efforts to deal with growing inflation and unemployment were still widely seen as weak and ineffective. The song lyrics also implied, oddly, that a vote for Ford was a vote for change. Yet in order for this assertion to resonate with voters, they had to distance Ford in their minds from the disgraced President who had tapped him to be Vice President before resigning. For many people, a vote for Ford was voting the status quo, and Ford, though uninvolved himself in the Watergate break-in, was for many a lingering apparition of the horrors that had led to Ford's accession to the Presidency. Ford was perceived for better or worse as the establishment 
candidate. For many, this was an unfortunate association as trust of government insiders was at an all-time low. Of course, his pardon of Nixon, which many saw as part of a corrupt bargain between Nixon and Ford, cast a large shadow over the 1976 election. In trying to generate positive feelings in voters about an incumbent President, where Reagan's “Morning in America” would succeed eight years later, Ford's "Peace" failed.

Like other advocacy ads that preceded it (such as "Nixon Now" four years earlier), "Peace" features a song sung by a chorus with light rock accompaniment (guitars, bass guitar, drum kit). Using a chorus to sing the lyrics makes an impression that we are all in this together and that crowds will be voting for Ford on Election Day. As corny as it seems to twenty-first-century ears, choral music was common in commercials throughout the 1970 and it was in "Nixon Now."

Thus, Ford's ad fit well with music in product commercials of the day. A male narrator at the end posits that Americans can rely on Ford to keep them safe and at peace. Using music similar to that in commercials could have made Ford look like the "safe" candidate for whom a vote is a choice not to "rock the boat." Ford was widely perceived as an honorable man who pardoned Nixon truly in order to allow the traumatized nation to heal without a protracted series of criminal proceedings and a Senate impeachment trial.

\section{South}

\section{Democratic Presidential Campaign Committee, Inc. Maker: Gerald Rafshoon oo:30}

Given how thoroughly fatigued the nation was with Watergate and its repercussions, voters were seeking a clean break with the past. Since Ford was so intimately connected with Nixon's scandal—despite widespread voter opinion that Ford himself was uninvolved and generally an honest man-many people wanted to vote for change, or, as Carter's ads claimed, "Jimmy Carter, a leader, for a change."

There had not been a President from the Deep South since the midnineteenth century. Ford did not just relinquish the South to Carter without a fight - he used an ad where South Carolina Senator Strom Thurmond spoke in favor of him.

"South," along with other ads, debates, and other campaign aspects, may have done their job, as Carter swept the South that November 2 (an 
achievement unique to Democratic candidates to follow). At first there is an establishing shot of a "Plains, GA" sign on a structure, Carter's hometown, where his father was a peanut farmer. The images and Carter's voice-over conform with the direct, no-nonsense aspect of the music. The camera tracks Carter walking past rows of crops with a denim work shirt with his sleeves rolled up. Then there is a similar shot, but this time with Carter approaching the camera. His full body is visible: he is wearing jeans, a big belt buckle, and a simple watch. The next shot of Carter is in a Western shirt, holding a pen and looking over papers; the camera zooms out to reveal Rosalynn with glasses sitting adjacent to him. The narrator at the end says "We in the South can help by electing a leader for a change." On-screen text at the end reads, "JIMMY CARTER/A leader, for a change/Paid \& authorized by 1976 Democratic Presidential Campaign Committee, Inc."

Of course, Carter's image as a simple peanut farmer is a bit incomplete as descriptions go. He had graduated in the top eight percent of his class at the US Naval Academy and spent much of his subsequent time working in nuclear energy. ${ }^{4} \mathrm{He}$ was a military insider and a political insider with state executive experience. Highly intelligent, adroit in politics, and possessed of a healthy dose of ambition, the governor was hardly the Everyman portrayed in the ad (or, for that matter, in his entire 1976 campaign).

Guitar is an apt choice for Carter's ad "South," which emphasized themes of Carter's down-to-earth nature and lack of guile. The music could not be simpler or more straightforward: it makes no pretense to sophistication or complexity. Throughout we hear the same simple chords ( $\left.-\mathrm{V}^{7} / \mathrm{IV}-\mathrm{IV}-\mathrm{I}\right)$ in $4 / 4$ and the same simple picking pattern. Carter's use of inartful music may have been purposeful. Although it is a detail, such music, closely associated in viewers' minds with the candidate, contributes significantly to the impression of Carter as an honest and guileless citizen, an honorable Southern gentleman. Music here is employed in order to wordlessly portray the candidate as an outsider, from outside the Beltway. Adjectives with which we might describe the music — straightforward, direct—adhere to Carter. The guitar is a particularly portable instrument, and an instrument that does not require a large financial investment to own. A simple, honest instrument for a simple, honest candidate.

By emphasizing his roots in Georgia, Carter was able to simultaneously present himself as an outsider to Washington politics, while at the same time highlighting his credentials as chief executive officer of a state.

4 Carter's role in shutting a reactor that had had a partial meltdown in 1952 helped shape his views on nuclear energy. 
(Seventeen US presidents were governors.) "South" makes the most of Carter's geographical difference and it does so in large part because of music chosen for the ad.

Eugene H. Roseboom and Alfred E. Eckes, Jr. note the emergence of a new and influential element in politics in 1976: "Finally, while ward walkers and campaign workers remained important in large cities to identify voters and turn out supporters on Election Day, strategic campaign decisions increasingly were made by a new middle-class, educated elite - professional campaign managers and consultants with no lasting personal allegiance to the candidate himself. Patrick Caddell, the youthful pollster for McGovern and then Carter, and Robert Teeter and John Deardourff, who served President Ford, were representatives of the new campaign elite who emerged on the scene. ${ }^{5}$ With a new class of campaign professionals beginning to edge out a candidate's loyal supporters that had earlier populated senior campaign staff, one might expect to see more savvy with regard to how a candidate is portrayed on television, including the aural aspect. But it will take a while before this expertise develops fully. In Chapter 8, we will see the aesthetic style of presidential ads continue mostly unchanged from 1976 . 


\section{The Ayatollah Casts a Vote: $\mathbf{1 9 8 0}$}

In 1980, in order to protest Soviet invasion of Afghanistan, President Carter instituted a grain embargo against the USSR as well as a US boycott of the Moscow Olympics. Diplomatic relations were initiated between Israel and Egypt. Robert Mugabe first took office as Prime Minister of Zimbabwe as his party won elections that ended white rule of what had been known as Rhodesia. The deposed Shah of Iran died in exile in Egypt. Polish labor organizer Lech Wałęsa started solidarność strikes at shipyards in Gdańsk, which eventually led to the Gdańsk Agreement that was recognized by the Polish government. A military coup d'état in Turkey supported by the CIA led to sweeping draconian changes throughout the country. In an innovation that would eventually lead to the creation of the World Wide Web, Tim Berners-Lee launched ENQUIRE.

Political ad music throughout the 1980 s was like the opposite of March, coming in like a lamb and going out like a lion. 1980 was one of the tamest television campaigns in presidential history; 1988 , one of its most vitriolic. The 1980 campaign, like the one four years earlier, used music in prosaic ways - as background and to create atmosphere. There was nothing to indicate the tectonic shift in political ad music use that would occur in 1984 and again in 1988. In the 1984 campaign, Ronald Reagan represented the establishment, and the ads reflect that. A coordinated campaign of ads presented a utopian vision of early 1980 s America, which as a whole came to be known popularly as "Morning in America." The Tuesday Team's cinematic conception with regard to shot and sequence composition and voice-over was matched by an equally painstaking effort in the music composed for the ad. With "Morning in America" we have for the first time the political ad qua aesthetic object. Here the positive or advocacy ad had reached its zenith. Four years later, a harshly negative tone prevailed in ads during the Dukakis-Bush contest. In fact, some of these ads remain among the most controversial in the history of political advertising. Some scholars consider 1988 the most negative campaign in history. So the 1980 s were a dynamic decade for political ad music.

Ted Kennedy presented a surprisingly strong challenge to Carter's candidacy in 1980; in fact, some people predicted that Kennedy would wrest the nomination away from the incumbent. ${ }^{1}$ Governor of California Jerry

1 For a thorough discussion of the political fight between the two, see Timothy Stanley, Kennedy vs. Carter: The 1980 Battle for the Democratic Party's Soul (Lawrence, KS: University Press of Kansas, 2010). 
Brown posed a somewhat lesser threat during the primaries. An additional movement was afoot to "draft Muskie" as interest in a candidacy of Edwin Muskie (Secretary of State and earlier US Senator from Maine) grew. But Kennedy remained as the chief antipode to Carter during the primaries. Historian Timothy Stanley elaborates: "The primaries took place against a backdrop of economic decline, cultural upheaval, and humiliation overseas. The Democratic Party was bitterly divided over how to respond to these challenges, and the cautious Jimmy Carter and the radical Edward Kennedy represented wildly different approaches to complex and seemingly intractable problems." A third party challenge mounted by centrist John Anderson (who had lost in the Republican primaries) did not generate much voter interest at the polls, though his inclusion in the debates did make him more known around the country.

All of this played out while American minds were frequently on the Iranian hostage crisis, an ongoing situation that cast a large shadow over the 1980 election. While in the short term, the issue boosted Carter in popular opinion polls, over the long term, it damaged irrevocably his credibility in foreign policy when he was unable to bring the situation to a satisfactory, or indeed any, conclusion. Reagan, of course, capitalized on this fact, along with other issues on which he claimed credibility with his experience governing California.

\section{Peace \\ Reagan \\ 02:00}

At the beginning of Reagan's "Peace," we hear an air raid siren as the narrator talks about strong leadership. The siren shrieks alarmingly, aurally depicting foreign policy matters that Carter (it is implied) is not equal to addressing. After this brief aural signal, there is silence as the narrator speaks, alternating with clips of Reagan giving a speech. At 01:24, majestic orchestral music begins with a motive that sounds strangely like a slowed-down version of "Hail to the Chief" (which it obviously could not be) after Reagan says, "prospects for peace." This music is best characterized as an orchestral hymn. The music reaches a satisfying crescendo as the narrator says, "Strength, restraint, inspired leadership" — and the music, with prominent brass and poignant suspensions, conveys strength and inspiration. Reagan 
had served as governor of California, so there was no shortage of pictures or video sequences of him "looking presidential" (or least "looking executive") while discharging his gubernatorial duties. Here music asserts that Reagan is presidential material, and that he is the one to assure peace for the US. Although lacking the panache and polish of "Morning in America," "Peace" seems to prefigure the inspiring cinematic style to follow in four years.

\section{Liberty Park/Hope Campaign 80 Reagan \\ 01:00}

"Liberty Park" uses music at the very end — the same music that closes the ad "Reagan's Record," from the same campaign. ("Reagan's Record" touts the candidate's allegedly excellent fiscal stewardship of California during his tenure as governor. It ends with the narrator's quoting an article from the San Francisco Chronicle claiming that Reagan had saved the state from bankruptcy.) This kind of musical repetition across ads (meant to stick in voters' minds) started here with Reagan's 1980 campaign, but would be even more noticeable in 1984. This music is not as sweeping, slow, and majestic as the music for "Peace," but it is inspiring and uplifting.

\section{Commander}

\section{Carter/Mondale Re-Election Committee Rafshoon Communications 01:00}

First aired on August 29, 1980, "Commander" uses mostly brass and percussion to associate President Carter with pomp, majesty, and seriousness of purpose.

The music enters just as the narrator says, "an experienced military man." Drawing a strong contrast between Carter, an alumnus of the US Naval Academy with a distinguished naval career, and Reagan, a B-movie actor whose only public service consisted of his tenure as governor of California.

3 Many campaigns then, as now, had "buy-outs" of their campaign music. In other words, campaigns purchase music for a campaign ad and receive in turn for a fee unlimited use of that music for the duration of the campaign. (See Appendix 1.) So music purchased for use in one ad has often been heard in other ads of the candidate for the same election cycle. 
This ad asserts that Carter's credentials are superior to Reagan's; it does this by omission. Rather than stating Reagan had little executive experience (and none of national significance) as well as no military experience whatsoever-something almost assumed to be a prerequisite for presidential candidates in earlier elections-Carter's ad merely implies Reagan's shortcomings. An uncommitted viewer open to either candidate would be forced when considering Carter's military record to reflect on Reagan's lack of experience in that arena.

Images in "Commander" are powerful indeed. But the music is the foundation for everything: it conveys confidence, nobility, and gravity. As the music is somewhat potted down in relation to the narrator, we almost feel its presence more than hear it. We are led to the idea that Carter has the military bona fides to exude strength and confidence so that he can transmit both power and restraint, to, as it were, speak softly while carrying a big stick. Tried and tested in wartime - he had served during the Korean War-Carter could continue to be the peacemaker that voters wanted.

That meant peacemaker with the Soviet Union primarily, but in 1980 , Americans were concerned with a threat of quite another cast altogether. In the wake of the Islamic Revolution in 1979, 90 hostages (including 53 Americans) were taken from the US Embassy in Teheran and were being held through the 1980 election. The demand was for the United States to surrender the deposed Iranian Shah, Mohammed Reza Pahlavi, for trial. In the summer and fall lead-up to the election, the Carter Administration was exceedingly frustrated with its inability to secure through diplomatic channels the hostages' release. This culminated in a botched rescue attempt called Operation Eagle Claw. Accordingly, they wanted to highlight Carter's military credentials with ads whose images and music based on the idea that a seasoned warrior should be re-elected to the Presidency in the hope that this appeal might defuse criticism of his administration's handling of the hostage crisis.

State

Carter/Mondale Re-Election Committee, Inc. 01:00

"State" shows Carter as President representing America abroad. There is no attempt at subtle music persuasion here; music only serves the function of characterizing the scenes as economic summit, review parade, or state funeral. "State" begins and ends on martial fanfares with emphasis on winds 
and particularly brass (which can symbolize royalty or military exploits), intended to remind voters of his Annapolis education and considerable military experience in contrast to his opponent. In the middle, we hear diegetic band music at state visits to Japan and China. Just like that in "Commander," music in "State" embodies dignity, competence, seriousness of purpose. Music here was intended to serve as an aural reminder that Carter was currently holding that position. In 1980, ads were still trying to sell candidates based on personal attributes and job performance.

As with Reagan, there was a unified approach to television advertising for Carter in 1980; "State" uses the same music as "Commander." His campaign was desperate to depict Carter as the calm and steady hand needed at the helm of a nation during stormy times. They knew well that the ongoing hostage situation as well as economic stagflation were threats to his reelection in the fall.

As the 1980 election approached, many problems weighed on the President - a deep rift in the Democratic Party between progressives who supported Ted Kennedy and establishment types who favored Carter, steep oil prices and interest rates, double-digit inflation, and the fact that fifty American citizens were still being held hostage in Iran. Though all was not his fault, Carter was blamed for enough of it that a Reagan presidency seemed more and more likely as time went on. Douglas Brinkley asserts that as bad as domestic troubles and internecine battles within the Democratic Party were, though, it was the hostage crisis that did him in: "Looking back at the 1980 election, it does seem possible that the Democrats could have ironed out their interparty squabbles had the crisis in Iran been resolved." The situation in Iran seemed dire indeed, and Election Day marked the exact date of the one-year anniversary of when the hostages were taken from the embassy. After having tried backchannel diplomatic negotiations, economic sanctions, and asset freezes with no success, Carter finally decided to take military action. Operation Eagle Claw ended in colossal disaster. The United States, many voters felt, appeared feckless. Reagan prevailed in the election, and on Inauguration Day, the hostages were released.

Meanwhile, Ruhollah Khomeini, known as the Ayatollah, leader of the successful Iranian Revolution, founder of the Islamic Republic of Iran, and the person who had contributed most to Carter's electoral defeat, soared in popularity in Iran following the election. He had been named Time magazine's Man of the Year in 1979. His influence continued into 1980, 
when events that he had set in motion contributed to an election loss for an incumbent US President. The title of this chapter is a reference to an October 27 New York Times column by William Safire entitled "The Ayatollah Votes."

In the 1980s, at least one television set was on for a total of seven hours daily in an average American household. ${ }^{5}$ So Reagan's TV ad attacks on Carter's record were falling on fertile ground.$^{6}$ Reagan's ease of presentation as an actor and his natural good humor stood him in good stead with the American electorate. Even with ads that were somewhat lacking in rhetorical power and aesthetic appeal, Reagan was able to convince voters to choose him. In the next chapter, we will see that if there ever was a year where music was most effective in political advertising, it was 1984 .

5 Michael Schaller, Right Turn:American Life in the Reagan-Bush Era, 1980-1992 (Oxford: Oxford University Press, 2007), 173 .

6 Carter had been developing a reputation as a feckless and ineffective leader. It did not help Carter that in 1979 The Atlantic had published an article by James Fallows called "The Passionless Presidency: The Trouble with Jimmy Carter's Administration." 


\section{Morning in America: 1984}

In 1984, full diplomatic relations between the Vatican and the United States were re-established. Macintosh's "1984" commercial, directed by Ridley Scott, was aired. Amid growing Congressional dissatisfaction with American military presence in Lebanon in the wake of attacks on US military barracks, President Reagan ordered the US Marines to withdraw from Lebanon. Miners in the United Kingdom began a year-long strike. President Reagan announced his support for an international chemical weapons ban. Operation Meghdoot was begun by India, leading to the Siachen Conflict between India and Pakistan over part of the Kashmir region. In response to the US boycott of the 1980 Olympics in Moscow, the Soviet Union refused to participate in the Summer Olympics in Los Angeles. Bruce Springsteen released his album Born in the USA. Burkina Faso became the new name of the republic known as Upper Volta. During a radio sound check, President Reagan joked about having signed a law that would "outlaw Russia," concluding, "We begin bombing in five minutes." P. W. Botha took office as State President of South Africa. Two of Indira Gandhi's Sikh bodyguards assassinated her; her son Rajiv took her place.

\section{CASE STUDY}

\section{Morning in America (Prouder, Stronger, Better) ${ }^{1}$ The Tuesday Team}

o0:30

Following on the heels of technological developments in sound reproduction in television sets and MTV's introduction three years earlier, the 1984 presidential campaign saw striking changes in the way ads were conceived and constructed. "Morning in America" — also known as "Prouder, Stronger, Better" - used music as never before in a political ad. Whereas previously music was merely accompaniment to an ad's voice-over and images, here, for the first time, music was the argument itself. Sweeping orchestral gestures, frequent chromatic modulations, and suspended chords led to a convincing

1 An earlier version of this case study was presented as a paper at the Annual Meeting of the American Musicological Society in 2012 in New Orleans. I thank Matthew Killmeier and Peter Martin for their insightful comments on this earlier version. Another version is in the Winter 2016 issue of the journal Music and Politics (see Bibliography). 
resolution ending with Reagan's name and picture. "Morning in America" stood out from other political ads and set a new standard for integration of image, music, and text.

Sound became all-encompassing. It was in 1984 that the Federal Communications Commission issued a directive allowing multichannel sound for television broadcasts, which had been experimented with since 1975 . In the wake of this decision, the market immediately obliged by integrating stereophonic sound into new television sets. Regular programming in stereo did not happen until the beginning of 1985 , but it had been broadcast sporadically from July $1984 \mathrm{on}$. Of course, ad agencies began to respond by producing television commercials with independent channels of audio.

Visual tableaux support the music's emotional appeal. The ad begins with scenes of everyday life as Americans begin their morning. ${ }^{2} \mathrm{We}$ see a lobster boat, a man exiting a taxi, a farmer backing up a tractor, a paperboy on a bicycle throwing a paper in the background as a man waves, smiles, and catches a ride to work, a family moving out of a house, a couple getting married with grandparents looking on. Lending a dreamy cast to the ad, soft light appears in every scene, at first only as points of light — headlights of car, bike, and tractor, candle flames, wedding grandmother's pearl earrings — but it gradually increases throughout the ad.

Nowadays, television political advertisements are one-minute, thirtysecond, or even fifteen-second affairs. In this extremely compressed timeframe, the ad's producers work to create in viewers' minds maximum meaning in minimum time. Thus music, like the visual and textual elements, conforms to its own specific advertising norms. Compared to earlier ads, "Morning in America" stands like a cathedral in the desert of political advertising, seemingly out of place and inspiring awe. "Morning in America" was only the beginning. Since then, campaigns have been producing ads with incredible musical subtlety and compelling soundscapes. ${ }^{3}$

2 All of the people visible in this "American morning" commercial are white, save two girls near the end of the ad who look up at a raised flag_-one Latina and one African American.

3 Examples are legion, but some of the most aurally persuasive commercials include George H. W. Bush's “Tank Ride” (1988), Bill Clinton's “Drums” (1996), George W. Bush's “Dangerous World" (2000) and "Wolves" (2004), and Barack Obama's "Firms" (2012). 

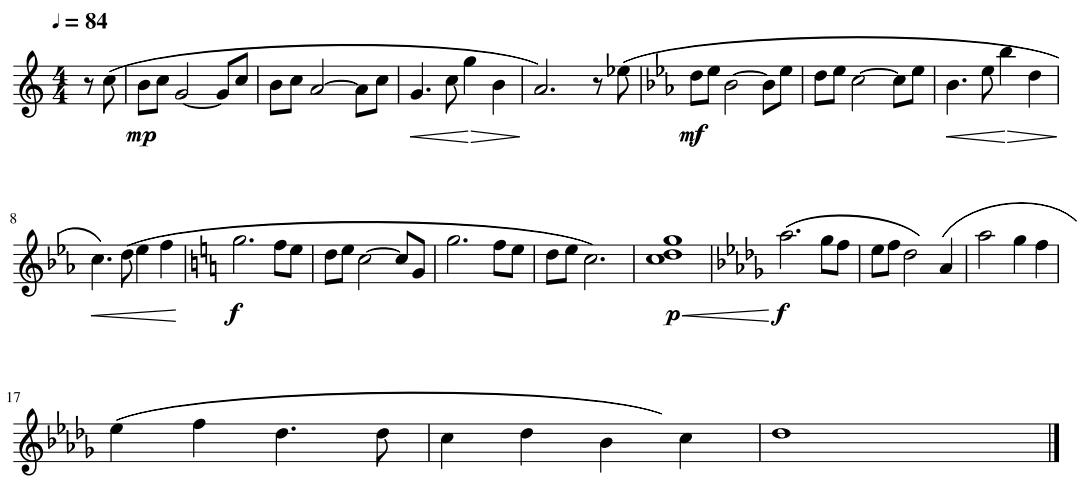

Fig. 9.1: Theme of Reagan's "Prouder, Stronger, Better"

Transcription of the main theme of "Morning in America"4

Reagan-Bush political advertisement in 1984 campaign

Symphonic music_-clarinet, piano, strings, horns prominent

Total time: 1 minute

\begin{tabular}{lllll} 
Time & Theme & Key & Chords & Length \\
\hline oo:00 & A & C major & I-IV-I-IV & $4 \mathrm{~mm}$. \\
oo:13 & A & Eb major & I-IV-I-IV & $4 \mathrm{~mm}$. \\
oo:25 & B & C major & I-IV-I-IV & $4 \mathrm{~mm}$. \\
o0:36 & X & C sus2 & $1 \mathrm{~m}$. & \\
o0:40 & A' & Db major & I-IV-I-IV-V-I & $6 \mathrm{~mm}$.
\end{tabular}

\section{NARRATOR'S VOICE-OVER:}

It's morning again in America

Today, more men and women will go to work than ever before in our country's history

With interest rates at about half the record highs [MODUL-Eb] of 1980 Nearly 2000 families today will buy new homes

More than at any time in the past four years

This afternoon 6500young men [MODUL-C] and women will be married And with inflation at less than half what it was just four years ago 
They can look forward with confidence to the future [HIGH CHIME, SUS CHORD]

It's morning again in America [MODUL—Db]

And under the leadership of President Reagan

Our country is prouder, and stronger, and better

Why would we ever want to return to where we were less than four short years ago?

\section{TEXT: PRESIDENT REAGAN / PAID FOR BY REAGAN-BUSH '84}

[Reagan's face on button, miniature gold-decorated American flag with two gold tassels]

Music is the sine qua non of this ad (see Figure 9.1). Dominating the discourse and supported by an insistent narrator and images meant to generate positive feelings in viewers, the music evokes contentment, satisfaction, and pride. Production values in "Morning in America" are high, and much consideration was given to how the ad can work as a unified whole, even as an aesthetic unity. ${ }^{5}$ Many call the ad "slick." Most viewers are unaware of how skillfully this message was crafted and polished to generate positive emotional associations with Reagan. Indeed, without analysis, we would scarcely be able to articulate exactly how this ad functions so effectively. Here music convinces not by logical appeal; it persuades through subterfuge.

It should therefore not surprise that the Reagan/Bush team engaged the services of a group of Madison Avenue advertising executives who called themselves the Tuesday Team, to create this and other ads such as "Russian Bear. ${ }^{\prime \prime}$ The Tuesday Team comprised volunteers, who worked fervently and for free. Heading the team was Sig Rogich, who was joined by Phil Dusenberry, Jerry Della Femina, and Tom Messner; their media consultant was Roger Ailes. This collaboration was the continuation of a long and fruitful association between Ailes and the Republican party, one which

5 In 1936, Walter Benjamin wrote of fascists aestheticizing politics, and "Morning in America" is by any standards an artistic endeavor (Walter Benjamin, "The Work of Art in the Age of Mechanical Reproduction," in Literary Theory: An Anthology, eds. Julie Rifkin and Michael Ryan [Oxford: Blackwell, 1998]).

6 "Russian Bear" implied that the USSR presented an existential threat to the US that could only be dealt with in the context of Reagan's "Peace through Strength" doctrine. The ad's ursine metaphor proved very effective-so much so, that the 2004 Bush campaign decided to use a vulpine metaphor for terrorists in their "Wolves" ad. For more on how music works in this ad, see Killmeier and Christiansen, "Wolves at the Door: Musical Persuasion in a 2004 Bush-Cheney Campaign Ad," MedieKultur:Journal of Media and Communication Research 50 (2011): 157-77. 
started in 1968 and continues to the present day: currently, Ailes is Fox News Channel president and Fox Television Stations Group chairman, and the relationship between Fox News and the Republican party probably needs no explanation. ${ }^{7}$ Ailes was responsible for creating the 1988 ad that made Willie Horton a household name-just as he had promised to do-and helped George H. W. Bush defeat Michael Dukakis.

The Tuesday Team's final product revolutionized political advertising as we know it. Narrated by advertising executive Hal Riney and featuring a series of scenes meant to depict a newfound optimism in America during Reagan's first term, the ad presented itself as a positive spot about Reagan's accomplishments, but really contained numerous rhetorical attacks on the Carter-Mondale administration, ending, "Why would we ever want to return to where we were less than four short years ago?" The enthymeme that the audience is expected to complete is "You mean return to when we weren't as proud, strong, or good? Well, of course we wouldn't!"

Many observers trace much of Reagan's resounding electoral success that year to this compelling ad, ${ }^{8}$ which furst ran on September 17,1984 . The Reagan/Bush campaign was far more innovative in advertising than their opponents, the Mondale/Ferraro campaign. The professionally produced, cinematically conceived Republican ads contrasted starkly with the roughhewn, folksy, and musically clumsy Democratic ads. Could the American public have connected professionalism in advertising to professionalism in the White House? Phil Dusenberry thought so and said as much in an interview for Online NewsHour: "We used top-notch filmmakers, topnotch editors, music people, and people did say it was slick. But as stated earlier, slick translates into really being professional and not looking like, you know, the primitive bio-films of the past." In the event, the Republican triumph that year was so complete that Mondale won the electoral votes only in his home state of Minnesota and in the District of Columbia.

By 1984, ads were no longer overtly about competence, experience, or policy stances. As with product commercials, political ads were focusing

7 The infamous Willie Horton "Revolving Door" ad in the 1988 presidential campaign was produced for the Bush/Quayle campaign by Larry McCarthy, who had worked for Roger Ailes. George H. W. Bush denied involvement in the ad's creation.

8 Not all scholars agree on this point. Darrell M. West, in his book Air Wars: Television Advertising in Election Campaigns, 1952-2008, $5^{\text {th }}$ ed. (Washington, DC: CQ Press, 2010) lists what he calls "memorable ads" from 1984 to 2008. The only ad from the Reagan-Bush 1984 campaign he lists is "Bear in the Woods" ["Russian Bear"].

9 Phil Dusenberry, in an interview with Jim Lehrer for PBS's Online Newshour https://web. archive.org/web/20140119041918/http. 
on lifestyle and identity. They were starting to elevate style over substance, with music as one of the key agents of creating the style. Whereas music in Carter's "State" ad from 1980 was diegetic and thus difficult to hear clearly or hear as a unified whole, "Morning in America" generated a powerful message with carefully calibrated underscoring, music that envelops the viewers. Production values in "Morning in America" reflected the wider trend in advertising to blur the line between content and advertising sponsoring that content.

Most striking musically about "Morning in America" are its three key changes, which raise the emotional stakes of the ad. They are often used in popular songs to ratchet up viewer engagement near the end of the song. Of pop modulations, Philip Ball writes:

In classical terms they are hardly modulations at all, but merely transpositions of key - what comes before bears none of the theoretical relationship to what comes after that true modulation entails, but is merely a repetition in a new key. We are not taken on a journey in harmonic space, but simply have the coordinate grid redrawn under our feet. ${ }^{10}$

Often, these harmonic resets are accompanied by other musical elements that create dramatic interest, such as swelling crescendos, cymbal crashes, and the like.

Key changes in "Morning in America" are direct modulations of the remote variety. Motion is initially to a key three flats removed (the chromatic mediant) and then back again, and finally to a key five flats removed. ${ }^{11}$ Indeed, this final chromatic semitone modulation could be said to musically embody the economic and social progress touted in the ad and it provides nonverbal support for the last line of text: Why would we ever want to return to where we were less than four short years ago? The exhilarating harmonic shift at the end of the ad lends Reagan what David Huron calls a "pump up" or "a gear change that injects fresh energy from the jolt.".12 The key change coincides with the resolution of measure 9's $\mathrm{G}$ to measure 14's Ab.

If we accept that "it's morning again in America," then the new D $b$ tonality could represent the dawning of a bright new day. We cannot return to the previous dark night, even if we wanted to. If I am wrong about the $\mathrm{C}$

10 Philip Ball, The Music Instinct (Oxford: Oxford University Press, 2010), 191.

11 There is something uncanny about pop music-type modulations in orchestral music.

12 David Huron, Sweet Anticipation: Music and the Psychology of Expectation (Cambridge, MA: MIT Press, 2006), 191. 
to $\mathrm{Db}$ key change as a metaphor for progress, it could be that the flat key symbolizes a return to a bucolic past or an ancient mythology of America as wide-open spaces of unoccupied land. In other words, the America imagined in the "New World" Symphony by Antonín Dvořák, that of his Largo (incidentally also in $\mathrm{D} b$ ). Whatever the specific interpretation, though, the shift from $\mathrm{C}$ to $\mathrm{D} b$ has a positive musical meaning that viewers are expected to associate with the incumbent President. The $\mathrm{D} b$ key change does not provide support for any quantifiable measure of Reagan's superiority. What it does do, however, is provide an emotional springboard for the words "and under the leadership of President Reagan, our country is prouder, and stronger, and better."

At any rate, the final key change is preceded by a dramatic musical colon: a subito piano sus2 chord on $\mathrm{C}$ juxtaposed against a picture of the US Capitol Building bathed in soft dawn light. This musical gesture creates suspense and anticipation resolved by the move to $\mathrm{D} b$ accompanied by a crescendo, sweeping glissando, and cymbal roll as we see a flag being raised in a rustic setting with the voice-over "It's morning again in America." This final section, lasting twenty seconds or a third of the entire length of the ad, sounds as though it is slowing down in anticipation for the final cadence. In fact, here the main theme is lengthened. This key change from $C$ to $D b$ is marked by a striking visual aspect: dawn light is transformed into full daylight for the remainder of the ad.

Although it has a pleasing contour, the ad's theme is static, its chief interest coming from instrumental timbre and the modulations it goes through. It is static because the fundamental motion in the first two A sections is mere oscillation between scale degrees 5 and 6 in the first two key areas. The same holds true for the B and A' sections, with oscillation there being between 5 and 1 in the final two key areas. Similarly noteworthy is the legato phrasing throughout, which lends the ad a soothing and reassuring cast. High shimmering violins on $G$ at the beginning seem to evoke the sun's rays peeking over the horizon.

Ad creators use a type of shorthand to convey their intended meaning, partly in the interest of time, and partly to fix the message in viewers' minds. This is true for music as well as for visual images and words. It is not just that the combination of visual images, voice-over, and music in "Morning in America" are together more than the sum of its parts; each part by itself is essentially unconvincing. The images are merely a disjunct series of pictures that we are meant to associate with America and more specifically with pleasant feelings about the US (paperboy, wedding scenes, Capitol Building, people raising American flags, sunlit flag fluttering in 
the breeze, miniature flag next to button with Reagan's picture, etc.). As Nicholas Cook remarks, writing about music in television commercials: "Music that is custom-written for a commercial frequently makes little or no sense when heard by itself, away from the context of words and pictures. Typically it is far too fragmentary to make sense in its own terms. Its logic is not the logic of concert music."13 While music in "Morning in America" does not obey all rules of common practice tonal harmony, it does have its own internal logic and narrative arc.

Music belongs to the nonverbal dimension that images also inhabit. The key changes operate in parallel to the verbal element, but in fact, music supersedes the text of the voice-over in importance. Logos in the ad is minimal. For instance, the second line of the ad, "Today, more men and women will go to work than ever before in our country's history," implies that Reagan is responsible for a decrease in unemployment since the Carter administration. The line does not assert this so baldly, though, it merely allows the viewer to connect the assertion to the candidate, leaving the thoughtful viewer to wonder whether the increase is accounted for merely by an increase in population, a decline in unemployment claims, or whether other factors irrespective of who is president may be responsible for the increase in employment. Assertions in many political ads do not stand up to scrutiny, and those in "Morning in America" are no exception. But since the main appeal is musical, cogent arguments are not de rigeur; indeed, they might distract from the powerful emotional appeal.

Further advancing the nonverbal dimension of the ad is the grain of Hal Riney's voice, which marks him as an avuncular, folksy figure, someone to be trusted. In conjunction with the music, this voice lends gravitas as well as reassurance. In Barthes's terms, ${ }^{14}$ Riney's voice is the narrator equivalent of that of Barthes's favorite singer Charles Panzera—thick with character and grit, satisfyingly material. We hear Riney's body in his voice. This corporality of the narrator's voice is analogous to what Barthes, following Julia Kristeva, called geno-song. ${ }^{15}$ Interestingly, the timbres of the instruments emphasized

13 Nicholas Cook, Analysing Musical Multimedia (Oxford: Oxford University Press, 1998), 9.

14 Roland Barthes, "The Grain of the Voice," Image - Music - Text, trans. Stephen Heath (New York: Hill and Wang, 1978), 179-89.

15 Scholar of religion John McClure explains the term clearly and succinctly: "Semiotician Roland Barthes calls this the 'geno-song' which gives expression to the sheer material beauty or voluptuousness of the way the words are 'bodied forth,' accentuating the shaping and uttering of sounds apart from their being communicable language in service to codes and conventions of proper speech and communication," John McClure, "Tone of Voice and the Expression of 
in "Morning in America" — strings, and especially clarinet and horns - are likewise closely connected to the bodies that produce those sounds.

Were there any precursors to "Morning in America?" Nine months prior to the first airing of "Morning in America," a spot appeared on national television that introduced a cinematic feel to TV ads. Directed by Ridley Scott, an advertisement introducing the Apple Macintosh personal computer was set in an Orwellian futuristic dystopia. The evocation of IBM PC owners as a horde of grey, male, laborer drones, contrasted starkly by the Mac user as a colorful, voluptuous, athletic woman, was hard to miss, as was the clear evocation of the Soviet Union in the first group and the United States in the lone female figure. (The Los Angeles Olympics were mere months away.) It first ran on December 31, 1983, and then again on January 22, 1984, during the second half of the most watched television event in the United States, the Superbowl.

Reagan's Tuesday Team wisely used the same music, with slight variations, in most of the ads the campaign ran.

\section{Train}

\section{Reagan-Bush '84 Producer: The Tuesday Team 01:00}

"Train" uses a version of the "Morning in America" music. It differs in key, orchestration, tempo, and dynamics. The ad is double the length of "Morning in America." The theme in "Train" is in G major ("Morning in America" begins in $\mathrm{C}$ major). First featured is the piano, followed by oboe. The theme then moves to the strings and brass. Tempo, at 75 beats per minute, is slightly slower. More muted and at a lower volume than in "Morning in America," the music allows the narrator to be foregrounded and the sounds of the train whistle and of people cheering. Music here seems to presume familiarity with the original version of the theme. With viewers who had seen "Morning in America," a connection could be made that solidifies the viewer's association of the heartwarming music with Reagan.

"Train" is one of several ads that together constructed the most successful US presidential campaign up to that time and possibly ever. While some video sequences are shared between certain ads in the campaign, it is the 
music that weaves it all together. It is the music that rings in viewers' ears. It is the music that lends the emotional force to invite voters to identify with positive feelings about the incumbent. Other ads that used variations on the theme, all 30-second spots produced by the Tuesday Team, were "Inflation," "Foreign Policy," "World Leaders," "Peace," and "Statue of Liberty." "Inflation," "Foreign Policy," and "World Leaders" all use the same G major music as "Train," except that the ending (in Ab) is spliced at oo:13 so that the music can finish in thirty seconds rather than sixty. "Peace" uses the same music as "Train" without alteration. "Statue of Liberty" is in A major, modulating in the middle to $\mathrm{B} b$, and it opens with oboe.

One ad that stood apart from the rest in Reagan's largely positive campaign was the iconic "Russian Bear." It was the one ad that introduced an element of fear for national security in order to urge viewers toward questioning Mondale's fitness to be Commander-in-Chief.

\section{Russian Bear \\ Reagan-Bush '84 \\ Makers: The Tuesday Team, Hal Riney \\ oo:30}

Standing apart from the unified Morning in America campaign are the ads "Reaganomics," "Supermarket," and "Russian Bear." The last one is of interest here. From the time of the czars until today's Russian Federation, including the intervening Soviet Union, the Eurasian brown bear has been the symbol of Russia and its associated states. In 1984, the Soviet Union's bear symbolism was common knowledge among Americans (this may not be the case so much anymore). The ad draws on popular associations for its impact. ${ }^{16}$ Here it is meant to represent the contemporary USSR. "Russian Bear," the only one of the aforementioned three ads that had music, is a propagandistic ad that was not only effective in the 1984 campaign, but also influenced political advertising thereafter. The 2004 Bush-Cheney "Wolves" ad draws from its well of inspiration, as we will see in Chapter 14.

The first scenes show various shots of a bear moving through a forest and a stream. Toward the end, as the bear moves right, the camera zooms out to reveal on the extreme right of the screen a man standing up

16 It would have been much more difficult for the USSR to create a propagandistic ad for Soviet TV using the metaphor of the American eagle, as it is a less threatening animal. But the bear worked perfectly for Reagan's purposes. 
courageously to hinder the bear's forward progress. He stands rock steady. Then the unexpected happens: the bear momentarily looks away from the man and then moves backwards cautiously, as if frightened by the man's presence. The implication is that America can and should stand up to the Soviet Union militarily and that they will cower in fear if we do. "Russian Bear" constructs an enthymeme for viewers. Since the Soviet Union is not explicitly mentioned, the viewer must supply the premise that the bear symbolizes the USSR, America's primary existential threat at the time, and the man symbolizes the United States.

Music in "Russian Bear" would scarcely be recognized as music per se by viewers; its power lies in its atmospherics. It consists of a series of strong and weaker drumbeats meant to evoke the heartbeat of the viewer. ${ }^{17}$ Hal Riney's rich, textured voice is highly foregrounded and closely miked. The heartbeat is strong throughout and the loudest sound after the narrator. Sneaking in near the beginning is music, which consists of long sustained electronic synth tones. As the ad continues, these gradually layered, soft, sustained tones are added, at first somewhat dissonant, and at the end pandiatonic. This pandiatonicism seems to offer hope at the end with Reagan's picture and the text "PRESIDENT REAGAN, Prepared for Peace."

Here is a transcript of the ad:

There is a bear in the woods. For some people, the bear is easy to see. Others don't see it at all. Some people say the bear is tame. Others say it's vicious and dangerous. Since no one can really be sure who's right, isn't it smart to be as strong as the bear? If there is a bear?

The rising tones at the end could be interpreted as anticipation of a confrontation-after all, that appears to be the visual message. This music carries the ad's rhetorical cargo. Feelings of unease in the listener rise from the insistent percussion and dissonant vertical sonorities of the first part. We interpret the music in light of the voice-over and video sequences. Visuals are important in "Russian Bear" because only the scenes can give context in which to understand the heartbeat effect. So it wouldn't have the same effect if it were a radio ad. Nevertheless, sounds dominate the ad until the end, when a compelling video sequence comes together climactically with rising audio.

17 The "heartbeats" in "Russian Bear" and in "Oval Office" (a Dukakis ad from 1988) are strikingly similar - here, the heartbeat is slower (about $38 \mathrm{bpm}$, compared to 6o bpm in the Dukakis ad) and the electronic tones are louder, though similarly dissonant. 
The central gimmick of the ad is the classic bait-and-switch. At the end, the narrator adds the rhetorical twist: "If there is a bear?" This is strange, because he stated at the beginning unequivocally "There is a bear in the woods," rather than the hypothetical "Suppose there were a bear in the woods." So the final sentence, which is really only a subordinate clause, conveys the sense that the ad is meant as a hypothetical, even though almost the whole voice-over (copy and grain of the narrator's voice), as well as the images and music, present the bear threat as reality. Music in "Russian Bear" helps conceal the rhetorical bait-and-switch. According to Claudia Gorbman, “[m] usic may act as a 'suturing device,' aiding the process of turning enunciation into fiction, lessening awareness of the technological nature of film discourse. Music gives a 'for-me-ness' to the soundtrack ... [A]nd music increases the spectator's susceptibility to suggestion. ${ }^{{ }^{1} 8}$

Another possible interpretation of the man stopping the bear's forward progress is that of geopolitical offense rather than national security defense; that is, that of America proactively attempting to stop the spread of communism, which had been a pervasive trope in US politics since the end of World War II. Such an interpretation is supported by an alternate understanding of the music. The bass drum with its regular beats might also imply a military marching cadence - left, left, left. If the ad had a snare drum tapping out a complex and unambiguous cadence with the bass drum, then that would remove the desirable ambiguity and nudge viewers toward an unequivocal interpretation of man versus bear as a geopolitical showdown. With just the bass drum, the heartbeat meaning is also possible, and not only possible, but — one might argue-more probable.

If we interpret the drum as a heartbeat, then together with the dissonant tones, we might imagine that he music is the aural representation of our inner dialogue as we confront the denizen of the woods. Obviously, we are fearful, but we overcome the fear to do the right thing, which, according to the Reagan administration, was to engage in a frontal assault.

Walter Mondale's campaign team made an attempt to create a campaign with some unifying elements, such as the music, but this effort was neither as consistent nor as polished as the totality of what the Tuesday Team produced.

18 Claudia Gorbman, Unheard Melodies: Narrative Film Music (London: BFI Publishing, 1987), 5 , as quoted in James Deaville, "Selling War: Television News Music and the Shaping of American Public.Opinion," ECHO: a music-centered journal 8/1 (2008) <http://www.echo.ucla.edu/Volume8Issue1/roundtable/deaville.html>. Accessed April 28, 2015. 
Limo

Mondale/Ferraro Committee, Inc. 1984

Consultants '84

00:30

In this ad, we see people stepping in and out of town cars, with no faces clearly visible. Although the music in this ad seems to be inspired by a horror film, as we will see, there are no Michael Myers-type homicidal maniacs in this story. The antagonists are the faceless "corporations," "defense contractors," and "foreign interests" benefiting from US deficit spending. Shadowy special interests are benefiting, it is implied, from cozy relationships with government representatives. "Limo" is about corporate welfare. Mondale was attacking Reagan's economic policies by showing unaccountable lobbyists with black limousines, a mobile symbol of power and influence. ${ }^{19}$

Here is the transcript:

MALE NARRATOR: In this building, Mr. Reagan's people are borrowing the money that's putting each of us $\$ 18,000$ into debt. Deficit spending. And who walks away with the money? Ninety thousand profitable corporations that pay no taxes, defense contractors on bloated budgets, foreign interests who make money on our debt. What the deficit really means is that you're paying for their free ride. But in November you can stop it. Mondale/Ferraro. They're fighting for your future. [TEXT: MONDALE/FERRARO]

John Carpenter's Halloween horror films (the original and sequels II and III) were released between 1978 and 1982. Music in "Limo" is close enough to the Halloween theme to evoke it in some viewers' minds (see Figures 9.2 and 9.3). The films were wildly popular and the films' theme was so well-known that people would sometimes sing the music when trying to scare someone. In addition to the prominent melody, there is an underlying hum of crowd sounds throughout. Also, we hear sirens and car sounds on "flourish." Falling minor second figures have historically represented sighs or laments. So even beyond the resemblance to the horror film theme, the music seems to express grief or sadness.

19 This is similar to a critique leveled by Republicans at well-to-do Democrats: "limousine liberals." 


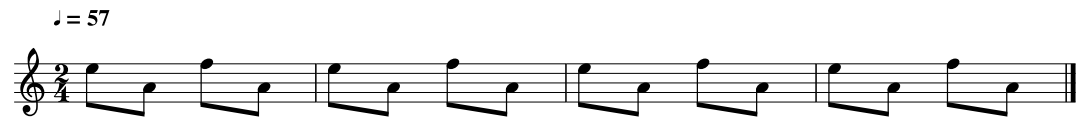

Fig. 9.2: Ostinato of Mondale's "Limo"

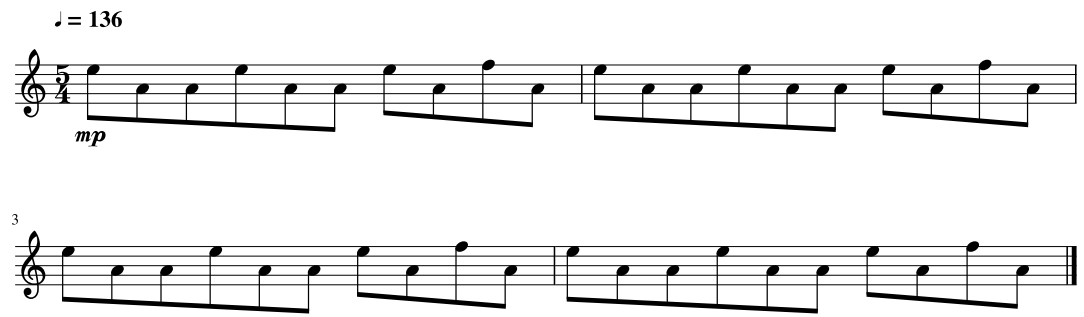

Fig. 9.3: Beginning of theme to Halloween II (1983) (transposed from F\# minor)

The repetitive ostinato of "Limo" could be interpreted to musically depict "business as usual." Corruption is the way things always are and always will be in government, unless it is acted upon by an outside force. Often, piano figures in negative ads are ostinatos in minor keys and they often have a similar meaning. ${ }^{20}$ In A minor, the theme of "Limo" is a bit slower than John Carpenter's Halloween theme in F\# minor, and with a different meter. But it is similarly repetitive, almost mesmerizingly so.

What is horrifying about the Halloween theme (essentially only three tones, rhythmically displaced)? It is the totality of musical elements: minor mode, repetition, high-register melody, an unsettling rumbling low drone on $\mathrm{A}$, and $\mathrm{F}-\mathrm{E}$ plaintive sighs.

The music, even if not associated with the Halloween theme, still sounds ominous and foreboding. In fact, the high figure can scarcely be called an actual melody; rather, it is an oscillation between $\mathrm{F}$ and $\mathrm{E}$, with $\mathrm{A}$ in between.

Oddly, the negative music continues even as the screen shows Mondale and Ferraro while the narrator says, "They're fighting for your future." This seems clumsy to twenty-first-century viewers, when political ad music is almost always closely synced to the candidate or opponent ("positive" and "negative," respectively, whatever those terms may mean contextually). 


\section{Loopholes \\ Mondale/Ferraro Committee, Inc. 1984 \\ 00:30}

Mondale's "Limo" passes the baton to "Loopholes," which uses a couple of the same video sequences of faceless people stepping into town cars as well as, crucially, the same music from "Limo." A male narrator says, "Over the last three years, those making over 200,000 dollars a year got a 60,000 dollar tax break. Thousands of profitable corporations pay no taxes." But rather than a negative ad like "Limo," "Loopholes" is a contrast ad: at oo:11 we see Mondale, who announces, "I refuse to make your family pay more so that millionaires can pay less." The orchestral music that accompanies him is in a fascinating upbeat neotonal idiom strongly reminiscent of Aaron Copland's "American style" as heard in pieces such as Rodeo, Appalachian Spring, A Lincoln Portrait, and Fanfare for the Common Man. Copland's later music is generally characterized by nervous, syncopated rhythmic figures, changing meter, open voicings of pandiatonic chords, and folk-inspired melodies. This Coplandesque style casts Mondale as a true "common man," an all-American candidate, fighting for the little guy, in contrast - it is implied - to the Republican candidate who supports millionaires and powerful special interests.

Such music fits well with the images of Mondale that we see. In almost every shot he is in a white shirt without a suit jacket, whether stumping on the campaign trail or talking with rolled up sleeves and loosened tie to construction workers in an unfinished house. In one shot for a campaign rally, Mondale even removes his suit jacket as if to "get to work" on the problems facing America. (Later in the ad we see the rest of the shot, where he casually tosses the jacket to an aide.) So in contrast to the formal wear of the first part of the ad about the millionaires, Mondale uses clothing to seem middle-class. All-American music encourages viewers to draw the same conclusion that Mondale is "one of us."

The unified approach of consistency of musical and visual style in "Limo," "House" and the negative section of "Loophole" helps viewers identify with the campaign as a whole, perhaps even subconsciously drawing on the intertextuality. At any rate, a unified approach to an entire campaign is usually a smart move. Nevertheless, Reagan's attempt was much more successful - the warm, orchestral, "feel good" music and patriotic imagery throughout most of the ads was a winning formula for the incumbent. 


\section{Failure 3}

\section{Mondale/Ferraro Committee, Inc. 00:30}

Another negative Mondale ad uses music only sparingly, but effectively, all the more so because there is no narrator until the very end of the ad. The message is a fragmented one, comprised of shots of newspaper headlines about world conflicts intercut with images from those conflicts. "Central America," "Secret War," "Nicaragua," "Lebanon," "Car Bomb Attack ... Embassy in Beirut," "Nightmare," "The Price of Failure," "Gromyko Comes,"21 "Star Wars." At the end of the ad, the screen text is MONDALE/FERRARO, Paid for by the Mondale/Ferraro Committee, Inc. At oo:21, a male narrator announces: "With the whole world at stake, it's time to move on, and we must do better. Mondale for president."

This harrowing opening scene does more than get the viewers' attention: music sets a frightening tone. A squad of soldiers marching through a tropical river scatters like rats toward the riverbanks at the sound of machine gun fire as the red text "CENTRAL AMERICA" shoots toward the viewer, growing progressively larger until it leaves the screen. Synchronized with the machine gun sound effect is a rolling timpani that crescendos toward a cymbal crash. After that, we hear ambient sounds of a helicopter's rotors as we see a military helicopter towing a smaller (presumably damaged) helicopter underneath it. Then there is the sound of a tank, which we do not see in a scene of soldiers walking through some rubble. After "Lebanon" flashes across the screen, we hear sirens and see figures running amidst a street scene of smoke, fire, and general destruction, which leads into the headline "Car Bomb Attack ... Embassy in Beirut."

Following this are two scenes in a hangar of Marines participating in ceremonies for numerous coffins draped in American flags with a large American flag hanging from the ceiling. During the first scene, we hear the clicks of military Honor Guard's precision flag bearing. Over the headline "Nightmare," there is another timpani roll, again leading to a cymbal crash. Then, the volume drops to pianissimo as we hear the military cadences of a snare drum, punctuated by timpani on $\mathrm{C}$ and $\mathrm{F}$, over scenes of missiles preparing for deployment (presumably a reference to the Star Wars missile defense program). The final picture is of Earth from space with the campaign text superimposed, accompanied by timpani strikes, snare drum, and another cymbal crash. 
Here a comparison can be made to Nixon's 1972 ad "McGovern Defense," which also chiefly uses percussion instruments, specifically a snare drum and a suspended cymbal. Nixon used this very effective ad to assert that McGovern would drastically reduce the size of the military and thus endanger the nation, and more broadly it implied that McGovern would be an unfit Commander-in-Chief. Whereas Nixon was positing that McGovern wasn't aggressive enough with national security, Mondale's ad uses the same military snare drum to imply that Reagan is too militaristic and thus too reckless to lead the country. Same percussion, different implication.

By no means naïve with regard to mass persuasion and able to harness the power of media, the Republicans were, like the Democrats, still one-dimensional in their vision of how music could be used in political ads. It wasn't until the 1984 campaign that music truly began to persuade surreptitiously. The Tuesday Team in essence created a new musical genre: political ad music, carefully scored music joined seamlessly with images and voice-over, as a self-contained rhetorical universe. Music and voice-over for the spot were created specifically to fit together line-by-line, with no jarring splices as we often see in older ads. It is music that doesn't call attention to itself.

We can see the Tuesday Team's legacy in recent political spots. "Morning in America" has had inordinate influence on the aesthetic of political ads to follow. The phrases "Morning in America" and "It's morning [again] in America" have been tropes in American culture since the ad first aired. Much of the positive feeling the ad evokes comes directly from the music. It is victor's music - Reagan was presented as a winner with his re-election seemingly a foregone conclusion — and it was to become a model for political ads to follow. ${ }^{22}$

The Tuesday Team did more than revolutionize political advertising with the greatest ad in the history of televised political ads in the United States. They also innovated by creating a unified, coherent campaign-using music. While there is some overlap of images and even narrator text among ads from the 1984 Reagan-Bush campaign, it is music that draws the ads together. Throughout the flow of television from ad to program to ad, it can be difficult to gain a viewer's attention. But by using essentially the

22 Political ad producer and co-owner of media firm Chi/Donahoe + Cole/Duffey Jim Cole, in an interview with the author (see Appendix 1), remarked that the media consultants who worked with him as he was producing a Human Rights Commission ad for marriage equality specifically requested that the ad's music be "like 'Morning in America," personal interview, July 11, 2013. 
same music in the majority of their ads, the Reagan-Bush campaign was able to immediately call to viewers' minds with, for instance, the ad "Train" the positive, patriotic universe of "Morning in America," which was the centerpiece of the campaign. "Morning in America" was the most polished and well-produced political ad of the year, and music was the bond between the entire aesthetic unity of "Morning in America" and its sister ads.

Incumbent President Reagan could afford to run a positive campaign, seemingly above the fray and declining to stoop to airing aggressively negative TV ads. Ceteris paribus, people generally prefer to feel good, and for many, basking in the patriotic glow of an ad for Ronald Reagan was a more attractive prospect than wallowing in challenger Mondale's negativity. It should be noted that the Mondale-Ferraro campaign was also experimenting with using the same music in a few ads, but they did it only sporadically. Mondale's approach can hardly be called systematic.

Reagan strolled to victory with a campaign that was both overwhelmingly positive and carefully orchestrated (in both senses of the word). The next chapter will discuss one of the most negative campaigns in the history of US presidential television advertising, one that got its candidate elected by substituting fear for hope and by making a previously unknown felon a household name. 


\section{Horton Hears a "Who?": 1988}

The Law of Cooperatives, a series of groundbreaking economic reforms, was passed as part of perestroika and glasnost in Gorbachev's Soviet Union. In a tense exchange, CBS news anchor Dan Rather challenged Vice President George H. W. Bush about the part he played in the Iran-Contra Affair; later that year, indictments of conspiracy to defraud the United States were issued for Lieutenant Colonel Oliver North and Vice Admiral John Poindexter. The Liberal Democrats formed as a new party in the United Kingdom. A precursor to revolution in eastern bloc nations in 1989, the Candle Demonstration took place in Bratislava, followed a few months later by the Singing Revolution in Estonia. As part of the Geneva Accords, the Soviet Union agreed to withdraw from Afghanistan. Socialist François Mitterand was re-elected President of France. The 8888 "People Power" uprising led to the death of thousands of demonstrating Burmese. War between Iran and Iraq ended. Osama bin Laden founded Al Qaeda. Climatologist James Hansen testified in front of Congress about man-made global warming, in an attempt to draw awareness to what he saw as an urgent issue. There were riots in Algiers and a plebiscite held for Chilean dictator Augusto Pinochet resulted in a decisive "no" vote against his continued rule.

If 1984 was the year of the positive ad, where the most successful ads were advocacy ads for the Reagan campaign, then 1988 was the year of the negative ad. Eighty-three percent of ads in the presidential general election in 1988 were negative in tone. ${ }^{1}$ This fact may not be surprising when we reflect on the reality that neither George H. W. Bush nor Michael Dukakis was a particularly charismatic candidate - the dry styles of both contrasted sharply with that of the Great Communicator, a smooth political operator who was about to leave office. Attack ads from the Bush campaign became almost as iconic as the Morning in America series of ads was for Reagan. In ads such as "Harbor," which criticized the Democrat's environmental record while Governor of Massachusetts, and “Tank Ride," which raised questions about the challenger's readiness to serve as Commander-in-Chief, Bush attacked Dukakis without mercy. The most famous of these ads was "Willie Horton," which set the ball of fear of violent crime, and "Revolving Door," which spiked it across the net with nobody to volley it back.

1 Darrell M. West, Air Wars: Television Advertising in Election Campaigns, $1952-2008,5^{\text {th }}$ ed. (Washington, DC: CQ Press, 2010), 70. 


\section{CASE STUDY \\ Revolving Door \\ Bush-Quayle '88 \\ Producers: Dennis Frankenberry and Roger Ailes o0:30}

Several ads in 1988 had overt racist connotations. "Revolving Door" is one of the worst. This infamous ad depicts a long line of prisoners entering prison and immediately exiting through a revolving door. It had been set up by the now famous "Willie Horton" ad, which Roger Ailes claimed would make Horton a household name. He was right. ${ }^{2}$ William Horton was an African American convicted murderer who, while released from prison on a weekend furlough, had attacked a white couple in Maryland, raping the woman and beating and stabbing the man. Focus group research conducted by the Bush campaign indicated voter receptiveness to an anti-crime message aimed at the furlough system.

In fact, so infamous was Horton as a character in political advertising lore, he is the topic of the first paragraph of a book entitled Race Appeal: How Candidates Invoke Race in U.S. Political Campaigns. ${ }^{3}$ The authors used Horton to introduce the entire topic of race in political discourse, concluding, "Horton's image is an enduring icon; it represents persuasive political-campaign communication at its worst-insidious in its intents and contemptible in its targeting of White fear of Black aggression and savagery."4 Horton is never mentioned in the ad, but the ad's creators wanted the name to come up in viewers' minds when they watched "Revolving Door." Showing the powerful image of an actual revolving door (rather than the narrator merely mentioning the metaphor) conveyed a sense of fear and dread among voters worried about crime.

The sonic world of "Revolving Door" works together with images and voice-over to create a frightening dystopian future. The pictures in black and white of mostly minority prisoners stoked suburban white fears of black criminals, black crime being disproportionally covered in the news.

2 This intertextuality between ads in a given campaign hearkens to Reagan's campaign four years earlier.

3 Charlton D. McIlwain and Stephen M. Caliendo, Race Appeal: How Candidates Invoke Race in U.S. Political Campaigns (Philadelphia: Temple University Press, 2011 ), 1.

4 McIlwain and Caliendo, Race Appeal, 1. 
Here is a transcript of the ad:

[TEXT: THE DUKAKIS FURLOUGH PROGRAM]

FX: door slam

MALE NARRATOR: As Governor Michael Dukakis vetoed mandatory sentences for drug dealers he vetoed the death penalty. His revolving door prison policy gave weekend furloughs to first degree murderers not eligible for parole.

[TEXT: 268 ESCAPED]

MALE NARRATOR: While out, many committed other crimes like kidnapping and rape, and ...

MALE NARRATOR [and TEXT]: Many are still at large.

MALE NARRATOR: Now Michael Dukakis says he wants to do for America what he's done for Massachusetts. America can't afford that risk.

Throughout, we hear low and high synth sounds, sounds like the swinging of a revolving door, and the steps of a guard ascending stairs of the watchtower.

In addition to a shot of the guard climbing the watchtower, we see a guard walking along a prison wall, holding an automatic rifle, as well as a close-up and medium shot of a revolving door made of steel bars. "Revolving Door" ends with a guard holding rifle atop a prison wall with a watchtower center screen.

The soundscape of "Revolving Door" is complex (see Figure 10.1). Horror music in "Revolving Door" has a structure similar to that of the 2004 "Wolves." A sound effect of a turning door is prominent, as is a low, attentiongetting thump heard at the beginning. Repetitive swooshing sounds seem to indicate that violent criminals are repeatedly being let out of prison to commit more crimes. A drone throughout makes the viewer uncomfortable. An accompanying table compares video sequences with voice-over, music, sound effects, and text and show how they relate to each other.

This ad took on a life of its own as it began to be covered by news programs, coverage that generated hours of free airtime for the campaign. 


\begin{tabular}{|c|c|c|c|c|}
\hline SHOTS & $\begin{array}{l}\text { VOICE-OVER (stressed } \\
\text { words in bold) }\end{array}$ & MUSIC & SOUND FX & $\begin{array}{l}\text { TEXT (in } \\
\text { white on } \\
\text { a black } \\
\text { banner at } \\
\text { bottom) }\end{array}$ \\
\hline $\begin{array}{l}\text { Establishing shot: A } \\
\text { guard armed with } \\
\text { a rifle walking up } \\
\text { a circular staircase } \\
\text { on a watchtower; } \\
\text { wooded hills in the } \\
\text { distance, zoom out }\end{array}$ & $\begin{array}{l}\text { AS MICHAEL DUKAKIS } \\
\text { VETOED MANDATORY } \\
\text { SENTENCES FOR } \\
\text { DRUG DEALERS }\end{array}$ & $\begin{array}{l}\text { Disturbing } \\
\text { low thump, } \\
\text { followed by } \\
\text { non-pitch- } \\
\text { specific } \\
\text { rumbling low } \\
\text { drone }\end{array}$ & $\begin{array}{l}\text { Midrange } \\
\text { mourn- } \\
\text { ful G-F\# } \\
\text { dissonant } \\
\text { minor } \\
\text { second, like } \\
\text { a moan/ } \\
\text { sigh }\end{array}$ & $\begin{array}{l}\text { THE } \\
\text { DUKAKIS } \\
\text { FURLOUGH } \\
\text { PROGRAM }\end{array}$ \\
\hline $\begin{array}{l}\text { Dissolve to } \\
\text { medium shot } \\
\text { of armed guard } \\
\text { walking perimeter } \\
\text { of prison wall }\end{array}$ & $\begin{array}{l}\text { HE VETOED THE } \\
\text { DEATH PENALTY. }\end{array}$ & $\begin{array}{l}\text { Drone } \\
\text { focused } \\
\text { on a low C } \\
\text { continues }\end{array}$ & & \\
\hline $\begin{array}{l}\text { Dissolve to } \\
\text { medium shot of } \\
\text { prisoners entering } \\
\text { and immediately } \\
\text { leaving through a } \\
\text { revolving door with } \\
\text { vertical bars }\end{array}$ & $\begin{array}{l}\text { HIS REVOLVING } \\
\text { DOOR PRISON POLICY } \\
\text { GAVE WEEKEND FUR- } \\
\text { LOUGHS TO FIRST } \\
\text { DEGREE MURDERERS } \\
\text { NOT ELIGIBLE FOR } \\
\text { PAROLE. WHILE OUT, } \\
\text { MANY COMMITTED } \\
\text { OTHER CRIMES }\end{array}$ & $\begin{array}{l}\text { Low drone } \\
\text { continues }\end{array}$ & $\begin{array}{l}\text { Repeated } \\
\text { swooshing } \\
\text { sound as } \\
\text { door moves } \\
\text { through the } \\
\text { air }\end{array}$ & $\begin{array}{l}268 \\
\text { Escaped. }\end{array}$ \\
\hline $\begin{array}{l}\text { Dissolve to long } \\
\text { shot of same scene, } \\
\text { revealing long } \\
\text { lines of prisoners } \\
\text { entering and } \\
\text { leaving through the } \\
\text { door }\end{array}$ & $\begin{array}{l}\text { LIKE KIDNAPPING } \\
\text { AND RAPE, AND } \\
\text { MANY ARE STILL } \\
\text { AT LARGE. NOW } \\
\text { MICHAEL DUKAKIS } \\
\text { SAYS HE WANTS TO } \\
\text { DO FOR AMERICA }\end{array}$ & $\begin{array}{l}\text { Low drone } \\
\text { continues }\end{array}$ & $\begin{array}{l}\text { Repeated } \\
\text { swooshing } \\
\text { sound as } \\
\text { door moves } \\
\text { through the } \\
\text { air }\end{array}$ & $\begin{array}{l}\text { At the end of } \\
\text { scene: Many } \\
\text { are still at } \\
\text { large. }\end{array}$ \\
\hline $\begin{array}{l}\text { Dissolve to shot } \\
\text { of watchtower in } \\
\text { middle background; } \\
\text { guard in right } \\
\text { middle ground } \\
\text { standing on prison } \\
\text { roof with rifle point- } \\
\text { ing up and to } \\
\text { the left toward } \\
\text { watchtower; line } \\
\text { of tall streetlamps } \\
\text { on left }\end{array}$ & $\begin{array}{l}\text { WHAT HE'S DONE FOR } \\
\text { MASSACHUSETTS. } \\
\text { AMERICA CAN'T } \\
\text { AFFORD THAT RISK. }\end{array}$ & $\begin{array}{l}\text { Low drone } \\
\text { continues }\end{array}$ & $\begin{array}{l}\text { Repeated } \\
\text { swooshing } \\
\text { sound as } \\
\text { door moves } \\
\text { through the } \\
\text { air }\end{array}$ & $\begin{array}{l}\text { At the end of } \\
\text { scene: Paid } \\
\text { for by Bush- } \\
\text { Quayle ' } 88\end{array}$ \\
\hline
\end{tabular}

Fig. 10.1 Table of George H. W. Bush's "Revolving Door" 


\section{Harbor}

Bush-Quayle '88

Maker: Dennis Frankenberry

o0:30

Using a type of musique concrète, Bush's ad "Harbor" makes an emotional appeal to generate anger in the viewer. Unsettling and harsh are the low drone and higher synth strings sound effects such as the howling wind, seagull cries, and scraping metal complete the sonic background for the ad. Combined with this soundscape, the narrator's mournful and scolding tone creates a chilling effect.

The final sound effect is of water splashing into a pile of floating debris, the last one on-screen (dead fish are clearly visible). Images of sludge, contamination, and sewage are shown, with a sign reading DANGER RADIATION HAZARD NO SWIMMING halfway through the ad. Obviously, there is no proof that the sequences were actually shot in Boston Harbor (except for the initial establishing shot of water with a buoy in the foreground and the Boston skyline in the distance).

Overall, the effect on the viewer of "Harbor" is one of filthiness, grime, feculence. With images, it creates such a powerful negative impression that one imagines that he can smell the foul water. Julia Kristeva writes in The Powers of Horror of the abject as being the human reaction to a lack of distinction between Self and Other. ${ }^{5}$ (This is the surprise visit of Jacques Lacan's "Real" into one's consciousness. $)^{6}$ The idea is that a depiction such as "Harbor" reminds us of our own imminent death. It is unpleasant to watch. The Bush campaign tried with "Harbor" to connect Dukakis in viewers' minds to a scene of decay and death.

5 Julia Kristeva, The Powers of Horror: An Essay on Abjection, trans. Leon S. Roudiez (New York: Columbia University Press, 1982).

6 Jacques Lacan, The Seminar of Jacques Lacan: Book II: The Ego in Freud's Theory and in the Technique of Psychoanalysis 1954-1955 (W. W. Norton \& Company, 1991). An important aspect of the Real is its inexpressibility through language or any other means. Friedrich Kittler writes of the gramophone - sound writ large, that is — as representing the Real, as he posits in his book Gramophone, Film, Typewriter (Stanford: Stanford University Press, 1999). 
Tank Ride

Bush-Quayle '88

Producer: Dennis Frankenberry

o0:30

"Tank Ride" is an example of an ad whose efficacy is in part due to its lack of music. The narrator lists weapons systems and other defense funding against which Dukakis had voted. Various shots of a tank are shown, and the ad concludes with an unfortunate picture of a smiling Dukakis wearing a helmet and sitting in the cupola of a tank. The shot made him look ridiculous.

Like John Kerry's unfortunate windsurfing episode in 2004, Dukakis's photo-op was ill-advised. Dukakis, in trying to seem more presidential and prepared to assume the mantle of Commander-in-Chief, had instead set himself up for ridicule by Bush's campaign team. In September 1988, the candidate went to Michigan to visit the General Dynamics Land Plant to be photographed in numerous butch poses with an Mi Abrams tank. In arranging this photo-op, Dukakis was taking a page from Margaret Thatcher, who had done the same thing two years earlier with great success. But somehow it did not work out for Dukakis whether because of his short stature or his professorial appearance. In addition to looking foolish in the pictures, sound effects of the tank's rumbling sound and frequent squeaks in the ad ridiculed him aurally as well. The squeaky wheel sounds seemed to imply that were Dukakis to win the White House, the US military would be left in a decrepit state - without even WD-4o! As in "Revolving Door," the narrator concludes with the devastating "America can't afford that risk." Here is the transcript:

MALE NARRATOR: Michael Dukakis has opposed virtually every defense system we developed.

MALE NARRATOR [and TEXT]: He opposed new aircraft carriers. He opposed anti-satellite weapons. He opposed four missile systems, including the Pershing II missile deployment. Dukakis opposed the stealth bomber, a ground emergency warning system against nuclear testing. He even criticized our rescue mission to Grenada and our strike on Libya. And now he wants to be our Commander-in-Chief. America can't afford that risk.

Dukakis had been excoriated by Republicans for vowing to pull back on Reagan's "Star Wars" missile defense program. The squeak sounds reinforce the "America can't afford that risk" slogan. Squeaks imply a lack of military 
readiness. The military would not be able to operate, it is implied, as a well-oiled machine under Dukakis's leadership. While not music per se, these sounds constitute a vital aural backdrop that strengthens the ad's effect. Dukakis's photo opportunity, made known to the public most effectively through Bush's ad, became a frequent joke among Republicans. At a fundraising dinner in June 1989 for Marshall Coleman, the Republican Party nominee for Virginia governor, Bush made a joke at Dukakis's expense: "But Marshall, you're our candidate. Certainly you have my full support, and you know Virginia better than I do, but let me give you a little free advice: Don't film your TV ads riding around in a tank."

\section{Furlough from the Truth \\ Dukakis-Bentsen Comm, Inc. Producer: Anthony Podesta o0:30}

The word "furlough" took on a vaguely sinister cast in 1988 because of "Revolving Door," which had accused Dukakis of releasing violent offenders from prison on weekend furloughs, allowing them to commit the same crimes for which they had been incarcerated. With this ad, Dukakis thoroughly refutes the "Revolving Door" ad point by point and also raises questions about Bush's own record on furloughs. But since "Furlough from the Truth" just used logic and rationality to dispute the claims rather than other means such as humor or music, Bush's ad remained "unrefuted" on an emotional level. As noted earlier, music, sound effects, and the tone of a narrator's voice cannot be refuted. The ad's sole aural element was the narrator's voice-over. Democrats still had not taken lessons from Republicans about how to use music to persuade voters. The phrase "Furlough from the Truth" was too clever by half. It did not conjure a vivid image as "Revolving Door" had done. A revolving door, where violent criminals are sent into prison just to immediately walk back out, is a compelling and frightening image. But "Furlough from the Truth" had no such powerful imagery.

In addition, Dukakis's campaign incorrectly calculated that the public would be disgusted by the racist attacks on his record and that such appeals would backfire as decent people recoiled in horror. By the time Dukakis

7 George H. W. Bush, "Remarks at a Republican Party Fundraising Dinner in Richmond, Virginia," June 21, 1989, The American Presidency Project http://www.presidency.ucsb.edu/ ws/?pid=17190. Accessed August 23, 2016. 
realized that the ads were being taken seriously and began to defend himself, though, irrevocable damage had already been done.

\section{Oval Office}

Dukakis-Bentsen Comm, Inc. Producer: Scott Miller oo:30

Using a beating heart as its appeal to emotion, Michael Dukakis's ad "Oval Office" highlights the fragility of human life in order to frighten voters into voting for the Dukakis-Bentsen ticket. The beating heart has long symbolized music at its most basic. For sixth-century philosopher Boethius, musica humana formed one of the three primary categories of music. Underlying musical rhythm and meter is the concept of "pulse." "Oval Office" begins with a heartbeat. Five seconds in, a low drone is added, with synth strings coming in five seconds after that. The heartbeat, low drone, and layered synth sounds continue until the final five seconds, when we once again hear only the heartbeat. Implied, of course, is that the Vice President is a "heartbeat away from the presidency," as the popular phrase goes. The takeaway of this ad was that the life of a sexagenarian was the only thing preventing the Vice President from assuming the Oval Office. Just as Sarah Palin was to be two decades later, J. Danforth Quayle had been roundly criticized for his temerity at accepting the nomination, not only because of his thin résumé, but also because he was seen as something of a cipher.

Many were astonished when George Herbert Walker Bush chose (or was advised to choose) Quayle as running mate. Quayle's credentials as an ideological conservative, it's true, were beyond reproach — in fact, he made Bush appear more moderate by contrast. What was questioned by many, though, was the Veep candidate's competence and ability to serve in the second highest office in the country.

An empty chair in the Oval Office is meant to scare voters with the thought that Quayle, widely perceived as lacking in intelligence and other essential presidential qualities, would actually have to assume the nation's highest office before Bush's term was up, as had nine Vice Presidents before Quayle. The low drone, continued with the higher sustained synthesized tones, creates an unsettling feeling with viewers. The deep, resonant heartbeat has primacy of place: for five seconds at the beginning and five seconds at the end, it alone is heard. It carries the heft of the emotional weight in the ad. 


\section{Counterpunch}

Dukakis-Bentsen Comm, Inc.

Producer: Scott Miller

01:00

In another attempt to defend himself, Dukakis shows a clip from the Bush ad "Tank Ride" before shutting the TV off with the words "I'm fed up with it. Never seen anything like it in twenty-five years of public life. George Bush's negative TV ads, distorting my record. Full of lies, and he knows it." Dukakis is earnest and he speaks passionately about what he stands for. But the counterpunch seems not to have landed; it seems at most a weak parry. The overall tenor of Dukakis's ads shows a candidate in a desperate defensive position. Bush kept Dukakis off-balance the whole election season and he never gained his footing.

That music per se is underutilized in the 1988 election may seem surprising in the wake of the most innovative and imaginative use of music to date in a US presidential campaign. Yet 1988 seems like an atavism to a time before "Morning in America"-almost like 1980, which was a desert of music in political advertising. Bush's campaign ads did an excellent job of harnessing the power of compelling soundscapes, in comparison to Dukakis, who seemed reluctant to include sounds beyond speech in his ads (the same reluctance we have noted in Democratic presidential candidates before him). Bush ads this year used music of various genres and for various purposes, but there was nothing like the musically compelling ads in a sustained and unified campaign for which Reagan had provided a model.

Bush took advantage of the ostensibly patriotic mood that obtained throughout the Reagan administration. Lee Greenwood's song "God Bless the USA" was spectacularly popular for its "America-love it or leave it" sentiment. The Bush campaign was anxious that voters not forget his eight-year association with the well-regarded President. (Others were not so eager to associate themselves with their predecessors, such as Johnson in 1964 or Gore in 2000.)

This campaign featured a number of prominent ads that evoked negative emotions. Fear characterized "Willie Horton," "Revolving Door," "Oval Office," and others; revulsion was palpable in "Harbor." The two 1988 adds that are most remembered today are "Willie Horton" and "Revolving Door." But Bush's ads were strikingly effective in making voters perceive a potential Dukakis presidency as frightening, unpalatable, and even revolting. This was done chiefly through music. 
In the end, Bush crushed Dukakis, winning electoral votes in forty states to Dukakis's mere ten states. US voters wanted a candidate who seemed tough on crime and the Bush campaign made sure to cast doubt on Dukakis's record in this regard.

Presently we will see what a contest between three candidates will yield in terms of political ad music in 1992. 


\section{It's the Economy, Stupid! 1992}

In 1992, the constituent parts of Yugoslavia started to break up and form independent nations, leading to instability and war in the region. In a gesture soon reciprocated by George H. W. Bush, Boris Yeltsin announced that the Soviet Union would cease to target with nuclear weapons cities in the United States and in countries friendly to the United States; this eventually led to a mutual declaration by the two governments of the end of the Cold War. The Montreal Protocol on Substances that Deplete the Ozone Layer and the Maastricht Treaty (which created the European Union) were signed by government leaders. White South Africans voted to approve reforms proposed by President F. W. De Klerk to end apartheid, which had been the law of the land for over forty years. Widespread riots in Los Angeles followed the acquittal of four police officers who had been videotaped beating black man Rodney King. The Twenty-Seventh Amendment of the US Constitution, having to do with Congressional pay, became law. The end of an era, The Tonight Show Starring Johnny Carson had its final show. Sparking great controversy, Sinéad O'Connor, during a Saturday Night Live episode, tore a picture with the likeness of Pope John Paul II on it after having sung a song in protest of child abuse by the Catholic Church. The NAMES Project AIDS Memorial Quilt was laid out in Washington, DC, to honor the memories of those who died from AIDS and to call national attention to the condition. A march of coal miners was organized in London to the ruling Conservative Party's plans to shutter a number of mines and make many miners redundant.

In the first presidential general election of the 1990s, George H. W. Bush was an incumbent President favored to win. But the independent candidacy of wealthy Texas businessman Ross Perot garnered a large amount of support, drawing chiefly from Republican voters uninspired by their party's candidate. At the same time, charismatic Arkansas governor William Jefferson Clinton entered the national stage. With a domestic policy message rendered simple by campaign manager James Carville as "It's the economy, stupid!" Clinton won a decisive victory in the electoral college of thirty-two states to Bush's eighteen. 


\section{Health Care}

\section{Bush-Quayle '92 General Committee, Inc. Producer: The November Company o0:30}

This Bush ad begins with a "slam" - a non-descript violent sound (relative to average volume in the ad) that immediately demands viewer attention. Right after the slam, which is really a synthesized bass drum strike, we hear a low, unsettling drone as the female narrator ominously intones, "Bill Clinton's health plan puts the government in control and that will ration health care." Use of the word "ration" is quite deliberate: many middle-aged and elderly voters would remember World War II ration books and the difficult rationing of goods such as sugar, butter, gasoline, and nylon stockings. But rationing in the 1940s was understood at the time as pitching in for the good of the country, whereas health care rationing seems capricious, unnecessary, and dangerous. "What if I need more doctor visits in a month than my allotment?" a voter might imagine. The Bush campaign had much success trying to scare voters using this term. "Socialism" is another scare word in the ad, as is "government [in control]." And when the terms are accompanied by disturbing dissonant music, the effect is powerful. In addition to the drone and irregularly placed bass drum strokes, we hear shrill synth strings. The most prominent sound effect is intermittent crying of a baby. This all creates in the viewer a feeling of dysphoria. As in other ads, it is the music that makes the viewer uncomfortable; the voice-over and text only tell viewers where to direct their discomfort.

In the course of the ad, there are three cuts to a black screen with white text: "Ration Health Care" at oo:04, "Medicare and Medicaid Cuts" at oo:12, and "It's Known As Socialized Medicine" at 00:22. Each of these cuts is accompanied by another synthesized bass drum strike. Drum strokes force the viewer to attend to the text on the screen. The ad concludes with "The Clinton Health Plan. Wrong for You. Wrong for America."

Notable about this ad was the use of a disembodied female narrator. Women had appeared in ads before even in 1952, but they were always on-screen. Women have constituted a majority of voters since 1980 , and

1 It was only in 2015 and 2016, thanks to the candidacy of Senator and self-proclaimed democratic socialist Bernie Sanders for the Democratic nomination that the term "socialism" started to lose its long negative connotations among the US electorate. "Government" is another term that has tended to poll negatively; Obama found this during the national debate on health care when "public option" was polling positively and "government option" negatively. 
there are always ads targeted specifically at them. Women voters might be expected to identify with a female narrator, and ads about health care often feature female narrators because of traditional gender role associations of women as caretakers responsible for family well-being. The female narrator and horror-type music in "Health Care" prefigure the 2004 "Wolves," brought to us by George W. Bush.

Images of an uncomfortable, crowded waiting room and an overworked doctor and receptionist, both struggling with reams of paperwork, convey to the viewer the idea that health care for all citizens would mean a dystopian future. The scene reinforces myths perpetuated by Republicans that in developed countries with universal health care, patients must wait interminably for rationed (i.e., limited by the government) medical services. Of course, the demonized code word "socialized" is used very effectively as code for "compromised, cut-rate government." Here is the transcript:

FEMALE NARRATOR: Bill Clinton's health plan puts the government in control and that will ration health care.

[TEXT: Ration Health Care]

FEMALE NARRATOR: And limit a doctor's ability to save your life. His plan would require $\$ 218$ billion in ...

[TEXT: Medicare \& Medicaid Cuts]

FEMALE NARRATOR: ... Medicare and Medicaid cuts in the next five years. His plan could cost 700,00o Americans their jobs. Government run plans have been tried in Europe, only there ...

FEMALE NARRATOR [and TEXT]: It's known as socialized medicine.

[TEXT: The Clinton Health Plan.]

FEMALE NARRATOR: You can't trust Bill Clinton's health plan. It's wrong for you. It's wrong for America.

[TEXT: Wrong For You. Wrong For America.]

"Health Care" is such a frightening ad, the viewer is relieved when it ends.

\section{Guess}

Bush-Quayle '92 General Committee, Inc. Producer: The November Company and James Weller o0:30

Like the frantic music in the 2004 George W. Bush ad "Wacky," George H. W. Bush's "Guess” features comically sped-up video sequences of Clinton's 
gubernatorial bill signing ceremonies. What is implied is that he is signing tax increases. These scenes of signing ceremonies all conclude with the advisers and legislators surrounding him applauding, as if they are celebrating the tax increases. Music sounds celebratory as well-like a tune for a hoedown. The rhetorical thrust of the music is that Clinton would frivolously raise taxes, unconcerned about the plight of the hard-working middle-class taxpayer.

Hoedown-type music with fiddle, banjo, and bass depicts Clinton as a hillbilly, a bumpkin. The rhetorical appeal of the ad employs the common technique of attacking a governor's or former governor's record to raise doubts about the candidate's fitness as President of the United States. Yet it is the music that most effectively situates Clinton where they want him to be-marginalized. Musical genre is all-important here. Most prominent as the ad begins are the fiddle and the banjo, an instrument closely associated with the South.

But there is more to it. Including country music in the ad is something of a cudgel Bush uses against Clinton; "Guess" attacks Clinton's gubernatorial record in his home state. ${ }^{2}$ In the twenty-first century, country music still appeals for legitimacy as a serious art form. In an article for the Pittsburgh Post-Gazette of May 10, 2001, Jim Patterson writes:

The country music industry will try to overcome a persistent inferiority complex with a self-deprecating advertising campaign aimed at encouraging fans to be proud and vocal. The slogan is "Country. Admit it. You love it." The campaign is the result of consumer research that found that many music fans hesitate to admit they love the music of such performers as Alan Jackson, the Dixie Chicks, and Tim McGraw. ${ }^{3}$

This quote tells us all we need to know about how stigmatized country music is in 2001, and the situation was assuredly no better in the early 1990s, when Bush was running the "Guess" ad. The Bush campaign, by using country "hoedown" music, was hoping to characterize Clinton as a hayseed not prepared for the complicated job for which he was campaigning, a hick wanting nothing more than to tax citizens into oblivion. (Given Bush's own

2 By explicitly naming taxes against mobile homes and beer, the Bush campaign might have been attempting to subconsciously appeal to voters who might favor Bush but who look down upon Southerners through stereotyping lenses - mobile home living, beer drinking, etc. This is highly speculative on my part, though.

3 Jim Patterson, "Campaign Aims to Take Stigma Off Country Music," Pittsburgh Post-Gazette, May 10, 2001, p. B19. 
renege on his "Read my lips, no new taxes" pledge, this appeal may have fallen on barren political ground.)

Particularly as paired with sped-up video sequences and country music - the music people are ashamed to admit they listen to- sound effects in "Guess" support the pasquinade of the ad. At the narrator's "raised state taxes" we hear applause, a sardonic swipe at Clinton. Then we hear, inexplicably, a car horn as the camera moves past rows of mobile homes and then we hear a supermarket scanner beep and see "HOSIERY, 1, 6.0o" on the checkstand digital screen as the narrator comments, "he increased the sales tax by 33 percent." Then, more applause as we see Clinton signing in accelerated motion at a signing ceremony.

As the camera pans across a mobile home again, we hear a dog barking, then a beer being poured as we see it onscreen (again, as the narrator talks about mobile home and beer taxes). As we see people taking pictures, we hear a shutter click (tourism tax), then we see Clinton in sunglasses playing saxophone on a snowy television screen with the sounds of TV static as well as unpleasant squawks on the saxophone (cable TV tax). At "supported a tax on groceries," we again hear scanners beeping as groceries are bagged. Finally the narrator says "And now if elected President, Bill Clinton has promised to increase government spending 220 billion dollars," and we see the text "220 billion dollars" in white text over another accelerated sequence of Clinton's signing ceremony, along with more applause.

Music and sound effects can be used to make an opponent appear incompetent or foolish. The saxophone squawks that we hear in "Guess" are meant to make Clinton sound musically incompetent, as if he were only a poseur who only pretends to be able to play an instrument in order to make himself appear talented or as someone not to be taken seriously as a presidential candidate. In point of fact, Clinton played tenor sax on the Arsenio Hall Show in 1992, and his performance was that of a reasonably talented amateur. ${ }^{4} \mathrm{He}$ even played at Prague's Reduta club in 1994 in the company of various dignitaries, including Czech premier Václav Klaus and president Václav Havel. ${ }^{5}$

So the approach of "Guess" is two-pronged: to depict Clinton as a country bumpkin and as a poseur not fit for the presidency. One attack aimed at Clinton's geographical background, while the other aimed at his personality. Of course, attacks based on geography could never be openly stated-after all, since Nixon's 1968 "southern strategy," the South was mostly firmly 
in the Republican camp, and it wouldn't do to offend a whole region of people. But the implied slight against Clinton's southern roots is there to be perceived in the music.

\section{Scary \\ Clinton-Gore' '92 Committee Producer: Clinton-Gore Creative Team o0:30}

As noted above, music's absence can also be attention-grabbing. Ad agencies have discovered that in the supersaturated musical environment of network and cable television, no music is sometimes the best music of all. Because the argument presented in "Scary" is complex (refuting a Bush ad point by point), the Clinton campaign chose to present the ad denuded of any "scary-sounding" music in an effort to get viewers to comprehend the message without extraneous noise. "Scary" would thus not have been the most successful ad from a poetic perspective, but it accomplished well what it set out to do. Other Clinton ads that year also eschewed music, such as "Second Chance" (about welfare reform) and "Rebuild America" (about jump-starting the economy, which was in a terrible recession).

\section{Kids \\ The Reform Party \\ Producer: The 270 Group 01:00}

In Ross Perot's ad "Kids," music is absolutely in the background, at a significantly lower volume than the narrator's voice-over. Almost as loud as the music is a sound effect of children playing loudly. Music in "Kids" sounds like a synthesized orchestra playing neotonal music.

The narrator's copy is projected in shadowed text in white in a vertical crawl as he reads, sentence by sentence. Background in "Kids" consists of monochromatic blue pictures of children's faces (an exception to the blue/ white chromatic scheme is the $\mathrm{O}$ of the very first word of the ad which appears as white on a red background). At the end, as the last picture dissolves into the Perot logo, we can see that the ad's body cleverly used only the three colors (in their exact shades) of red, white and blue that are in the campaign logo. Visually, the ad works well. Text about deficit control 
for "our children" is clearly conveyed. But music is not used effectively here and as a result the ad's overall impact is greatly diminished.

Perot's ad "Trickle Down" comes from the same mold as "Kids": the text is projected as the narrator reads it, and we hear relatively non-descript synthesized music over a prominent sound effect of rain falling. For the same reasons I delineate above in my discussion of "Kids," I find this ad effective visually and with regard to message clarity, but not musically. In this respect, both ads can be said to be of the "hard sell" variety despite some "soft sell" elements.

\section{Maine \\ Clinton/Gore '92 Committee Produced by Clinton-Gore Creative Team o0:30}

The title of the Clinton ad "Maine" refers to the Bush family compound at Walker's Point in Kennebunkport, which is so common a tourist attraction that there are drive-outs on the road that allow tourists to gaze at the palatial grounds from a safe distance (the entrance is heavily guarded). While the primary rhetorical thrust of the ad is about how Bush does not pay Maine taxes despite spending a lot of time in the state, there is also an undercurrent implied attack on him for being a blue-blooded New England aristocrat who does not care about average citizens. Who can afford an estate in Maine in addition to other properties. Voters might be envious, and this ad plays on that emotion.

Here is a transcript of the ad:

MALE NARRATOR: George Bush at home in Maine. George Bush boating. Back home in Maine. George Bush golfing at his home in Maine. In fact, you can find George Bush doing just about everything at his home in Maine except paying Maine taxes.

[TEXT: Except paying Maine taxes]

[TEXT: Houston, Texas]

NARRATOR: For tax purposes, he calls Texas his home. In fact, this Houston hotel has already saved George Bush over $\$ 165$,0oo in Maine taxes.

[TEXT: Bush saved $\$ 165,000]$

NARRATOR: And when George Bush saves $\$ 165,000$ in taxes, guess who makes up the difference?

NARRATOR [and TEXT]: You do. 
Transitions between sequences are dissolves and, notably, iris wipes, which look like a non-digital camera's shutter closing and opening (in this case we see a black background circumscribing a white pentagon around the video). The iris wipes are accompanied here by a sound effect of a camera clicking.

These iris wipes and camera clicks might be interpreted as a tourist taking snapshots of a celebrity. Such an interpretation would fuel the perception that Bush belongs to a sort of American aristocracy. A famous and instructive episode supposedly illustrating how out of touch Bush was from Everyman is the story of him allegedly marveling at a supermarket scanner. It did not actually happen that way, but the fact that the story grew legs illustrates that voters were willing to accept an anecdote that supported their own presuppositions. So the tourist snapping souvenir photos of the famous George Bush would remind voters that he is not like them. A key Clinton strategy in 1992 was to remind voters that both Bush and Ross Perot were ultrarich with multiple residences across the country as well as abroad, and to imply that they could not possibly understand the everyday problems and concerns of the middle class and working families.

This music sounds humorous, as if to depict Bush as comically out of touch. The bassoon has long had comic connotations, at times signifying a clumsy oaf or a buffoon. It symbolizes, for instance, Grandfather in Sergei Prokofiev's Peter and the Wolf and Sancho Panza in Richard Strauss's symphonic poem Don Quixote. That the bassoon is often thought of as a comedic instrument is demonstrated by a search of stock music websites such as stockmusic.com or Sound Ideas. ${ }^{6}$

Except for the very end, the music "spins its wheels" - that is, it doesn't make forward tonal progress. But in the middle, at oo:17, musical momentum starts to build, with a falling bass line and a crescendo, leading to a final cadence in the tonic. This cadence highlights the final phrase "You do," the focal point of the entire ad. Suspense in the music makes viewers listen closely for this final revelation.

6 Even YouTube yields a number of results, including an eleven-second cue "Lumbering Along Bassoon Comedy Accent” (https:/www.youtube.com/watch?v=FCgYRGu7gPw), a threesecond cue "Bassoon: Fanfare Accent, Cartoon Comedy Music," (https://www.youtube.com/ watch?v=gNzl $7 \mathrm{nVvBhE}$ ), an eleven-second cue "Big Charge Bassoon Comedy Accent" (https:// www.youtube.com/watch?v=9ruynejTtsk), and a ten-second cue "Uh Oh Bassoon Comedy Accent” (https://www.youtube.com/watch?v=02KEwGJnZBo). There are many other examples. Actor and comedian Rainn Wilson makes much of his amateur bassoon skills in his new book The Bassoon King and during a book-plugging appearance and riveting performance of "Mary Had a Little Lamb" on The Late Show with Stephen Colbert. 
In the next election cycle, Bill Clinton will continue to employ similar music in his ads. Bob Dole's music will be indicative of his more desperate position as challenger to the incumbent. 


\section{At Millennium's End: 1996}

In 1996, a ceasefire between Russia and Chechnya called an end to the First Chechen War. France ceased testing of nuclear weapons. As part of an investigation into the Whitewater scandal, Hillary Clinton testified in front of a grand jury. René Préval became President of Haiti, succeeding Jean-Baptiste Aristide. “Deep Blue," a computer designed to defeat chess champions, beat Russian Garry Kasparov; later, Kasparov triumphed over Deep Blue. Pokémon Red Version and Blue Version were released. In Burundi, there were massacres of Hutus and Tutsis, with hundreds falling within the span of several days. After the horrific Port Arthur massacre, Australia passed a measure that banned automatic and semi-automatic weapons for private citizens and included a buy-back provision, effectively ending mass shootings in the country. A sheep was cloned. A tribunal in The Hague issued arrest warrants against Bosnian Serb leaders Ratko Mladić and Radovan Karadžić for war crimes in the former Yugoslavia. President Bill Clinton signed a bill into law that drastically changed welfare in the United States, Operation Desert Strike was begun against Iraq.

The election in 1996 was between a popular incumbent President (newly resurgent after disastrous midterms for his party in 1994) and a well-liked Senator from Kansas and World War II hero.

By now we have seen that dark, foreboding music is used most often in television political ads when the candidate is desperate to win (Humphrey 1968, Mondale 1984, Bush 1992, Bush 2004). Bob Dole was in just such a situation in 1996, when prosperity at home and no major conflicts abroad seemed to clear the way for incumbent Clinton to keep the White House. Accordingly, Dole's ads struggled mightily to create the impression among voters that underneath all the optimism, robust economy, and relative lack of urgent foreign crises, something was unwell in the nation's government. Clinton's campaign picked up on this and even had an attack ad entitled "Desperate," where Dole's claims were deconstructed and refuted.

At the same time Clinton tried to chip away at Dole's greatest strengthsmaking Republican priorities (lower taxes, balanced budget, border security, welfare "reform," crime, etc.) Clinton priorities. Clinton had rushed rightward on the political spectrum in order to try to secure the ever elusive “centrist vote." Having appealed to Republicans, Clinton was able to tout a number of policy accomplishments on the 1996 campaign trail.

In addition to policy alignment with Republicans, the aesthetic style of Clinton ads invited comparison to Republicans. One Clinton ad, "The Facts," 
had a paperboy riding a bike, tossing a newspaper. This is almost certainly meant to recall in viewers' minds "Morning in America," presumably so that voters would associate positive feelings for Reagan with Bill Clinton. The shot of the paperboy is clearly unmotivated by the rest of the ad; viewers might rightly ask, "What is this paperboy doing in the ad?" Clinton's political position in 1996 was not unlike Reagan's position in 1984-an incumbent President with a comfortable lead due to high public approval ratings.

\section{Stripes \\ Dole/Kemp '96 \\ oo:30}

The premise of the Dole ad "Stripes" is that Clinton, in trying to fend off a lawsuit for sexual harassment, attempted to invoke the 1940 Soldiers and Sailors Relief Act (SSRA), claiming that as Commander-in-Chief he qualified for automatic legal delays "while on active duty." Images in the ad show Clinton in his most unbuttoned moments-on the golf course, jogging, cycling, with sunglasses during one of his saxophone escapades.

In this ad, we hear whistling of the song "You're in the Army Now." Reverb on the whistling adds a sardonic edge, making it sound as though an entire squad is whistling. ${ }^{1}$ Music here serves to ridicule Clinton, who had been accused in the campaign of avoiding the Vietnam draft using student deferments. ${ }^{2}$ A downward glissando on the final note of the whistle seems to imply the seriousness of Clinton's effrontery despite the humorous way he is portrayed in the ad. The book-ending phrase- "Bill Clinton ... He's really something," heard at the beginning as well as at the end-adds to the overall sarcastic effect. Implied is the question "Who the hell does he think he is?" The text of the song whistled here is:

1 Even timbre can tell part of the story, as in "Mainers Know," a 2012 US Chamber of Commerce ad against Maine Independent U.S. Senate candidate Angus King. Playing off his surname, the ad criticized him for being the "King of Spending" and of "Mismanagement" and urged voters to "declare your independence from this King." The instrument featured was a harpsichord, which is an instrument mostly associated in people's minds with the Baroque era, a time of absolute monarchs (who were not known for their frugality). The harpsichord's timbre is a crucial element in the ad.

2 Many Republican politicians of Clinton's generation have avoided the same draft in various ways, but Dole was a World War II hero whose military background was prominent in his overall profile. 
You're in the army now

You're not behind the plow

You won't get rich

By diggin' a ditch

You're in the army now!

Of course, Bob Dole himself was a World War II hero who had lost the use of his right arm due to German machine gun rounds. Some viewers reflecting on Clinton's alleged draft dodging and misuse of the SSRA were bound to contrast that with Dole's exemplary military record as a decorated enlisted soldier and officer.

The song comes from a 1942 Warner Brothers cartoon called "The Draft Horse." For those who not only recognize the song but also know the lyrics, the association of this song with a children's cartoon in some minds could have served to trivialize Clinton and make him seem like a person not to be taken seriously. Furthermore, the incongruity of Clinton's position of unparalleled privilege with the sad position of a lowly Army private makes the ad humorous.

\section{The Threat \\ Dole/Kemp' 96 \\ oo:30}

Dole's ad "The Threat" opens with a clip of Lyndon Johnson's "Daisy" ad of 1964, which many voters remembered from its original airing (in the US, the elderly vote in greater numbers than any other age group). Such strong associations have accreted to that ad. ${ }^{3}$ Instead of nuclear war, says the female narrator, the threat today is drugs. She outlines what voters should consider Clinton's "problematic" policies on drugs. At the end of the ad, a boy with what looks like a crack pipe and a lighter in his hands turns abruptly toward the camera, startled.

As the boy turns around, we hear a highly dissonant, jarring stinger. Viewers watching this ad will be made uncomfortable by the sounds they are forced to hear. If they subconsciously connect those unpleasant sounds to Bill Clinton, the ad is successful.

3 For more information, see Robert Mann, Daisy Petals and Mushroom Clouds: LBJ, Barry Goldwater, and the Ad That Changed American Politics (Baton Rouge: Louisiana State University Press, 2011). 
Music in "The Threat" prefigures the full-blown horror film mini-score of George W. Bush's “Wolves.” Foreboding and menacing, the ad's music represents the threat referred to in the ad. As with other ads, we should always ask ourselves whether the ad would have worked without music. It seems clear that "The Threat" would not have been as effective if it lacked music, which contains the primary emotional impact.

\section{Classroom \\ Dole/Kemp ' 96 \\ oo:30}

Given that the first screen text (and the first words spoken by the male narrator) are "Two million illegal immigrants," it should not be surprising that the music sounds Orientalist. Sound effects here are the musical analogs for jungle sounds. Subconsciously, viewers might associate the music with the Far East as represented in countless Western films (for instance, about Vietnam). In some ways the music sounds like the jungle, in some ways Orientalist, in other ways like a suspense thriller. These different connotations are not mutually exclusive-they need not be. The point is that the music is unsettling and difficult to listen to. With "Classroom," the Dole campaign wanted to make voters uneasy about Clinton's record on immigration. "Exotic" music was meant to convey that message nonverbally (and most powerfully). Essentializing minority immigrants with Orientalist music can have a powerful emotional effect.

\section{Drums}

Clinton/Gore ' 96

Producer: The November 5 Group

oo:30

A contrast ad, "Drums" is truly rare among political ads in that music is the only aural component; that is, no voice-over or sound effects distract from the message conveyed by the percussion instruments and the onscreen text. In the first half (the Dole half) we hear snare drum, timpani, and cymbal crashes to create a quasi-classical orchestral percussion composition in miniature. The timpani are played in a lumbering fashion on $\mathrm{C}$ and $\mathrm{G}$. The overall impression is of a stodgy, stuffy, stiff candidate. 
The Clinton half features an electronic drum kit, skillfully played with a jazz feel, a scorching drum solo with much exciting syncopation and staccato. At the very end there is a synthesized chord to highlight the final text, "When it comes to America's future, which drummer do YOU want to march to?" Throughout synthesized melodic notes lay extra emphasis on certain drumbeats, which in turn emphasize text words. This is the jazz of the so-called "first Black President," the sax player in sunglasses, the Blues Brother. Who wouldn't want to "march to" that phat beat?

"Drums" innovates with clever literality. "Marching to a different drummer" is highlighted. Once again music makes the assertion. Like many Clinton ads in 1996, it had a bi-focal approach: advocacy and attack. The Manichean choice between Clinton and Dole is presented visually as well as aurally: red appears in the Dole half, whereas blue is seen in the Clinton half. These colors have particular psychological associations. Mubeen Aslan writes of red symbolizing "lust, negative issues, excitement, love" and blue symbolizing "masculine, competence, high quality, corporate."4 Other associations with red are "blood," "anger," or "stop." Blue calms and reassures voters, especially in contrast to red. In terms of simplicity and straightforward effectiveness, "Drums" that year was nonpareil, compelling both visually and aurally.

\section{Surgeon \\ Clinton/Gore '96 General Committee Producer: The November 5 Group oo:30}

Clinton spots from 1996 are largely dual advocacy/attack ads ("Desperate," “School," “Tell," “The Facts," “Drums," "Signed," "Accomplishment”). In "Surgeon," scenes shift back and forth between smiling, full-color Clinton and scowling, black-and-white Dole with dizzying rapidity. For each scene change, music toggles from major mode inspiring themes to bleak, minor mode passages and back again, matching the video frame by frame. In fact, to the practiced ear, such lightning-fast musical gear shifts can seem comical, even though they are mostly artfully achieved.

A double-pronged advocacy-and-attack approach pervades "Surgeon." From 00:00 to 00:19 and from 00:24 to 00:30, Clinton's policies are mentioned

4 Mubeen M. Aslan, "Are You Selling the Right Colour? A Cross-Cultural Review of Colour as a Marketing Core," Journal of Marketing Communications 12/1 (2006): 15-30. 
and joyful scenes unfold in Technicolor. The remaining five seconds in the middle are devoted to mention of Dole's plans to cut education funding and (in a clip of him talking) to eliminate the Department of Education. Instrumentation in the Clinton sections comprises piano, oboe, clarinet, and bass; Dole's section has a repetitive piano motive.

The Dole key change to F\# minor is subtle and hardly noticed because it is the relative minor to the A major that preceded it. Although the Dole section in isolation sounds certainly different from the Clinton sections, musical transitions are smooth and nearly seamless. The key scheme for the ad is as follows:

$\begin{array}{lll}\text { Clinton } & \mid \text { Dole } & \mid \text { Clinton } \\ \text { A } b \text { major } \rightarrow \text { A major } & \mid \text { F\# minor } & \mid \text { F\# major } \\ & (\text { with low F\# drone) }\end{array}$

Three harmonic changes in the ad draw on the semiotics of traditional harmony. The first one, a semitone modulation from $\mathrm{A} b$ to $\mathrm{A}$, is followed by a shift to A's relative minor, $\mathrm{F} \#$ minor, and finally from $\mathrm{F} \#$ minor to its parallel major. As we saw in Chapter 9, modulation up by semitone can signify progress, which works for representing Clinton. The second one, a key change to the relative minor, often signals a turn toward the melancholy or the mournful. This is Dole's section. The final harmonic move is from a minor key to its parallel major, which has traditionally meant triumph over adversity (Beethoven's Fifth Symphony is the textbook example). Clinton triumphs over Dole semiotically.

Musical trends in 2000 will not differ much from those of 1996, as we will see. 


\section{Bush v. Gore: 2000}

In 2000, in the largest corporate merger until that time, Time Warner was purchased by America Online. Vladimir Putin was elected President of Russia. The anti-trust case United States v. Microsoft Corporation was resolved against Microsoft. A demonstration against globalization took place in Washington, DC. India's population reached one billion. Bashar al-Assad was elected as his father's successor in Syria. At Bill Clinton's urging, Yasser Arafat and Ehud Barak met to hammer out a peace agreement, but talks ultimately failed to produce a tangible result. During naval exercises, the Russian submarine Kursk sank and all aboard perished. Suicide bombers from Al Qaeda blew a large hole in the naval destroyer USS Cole. Hillary Clinton was elected to represent New York in the US Senate.

The year 2000 had no incumbents running for president, but both candidates had ties to earlier administrations. George W. Bush was the son of the forty-first President, and Al Gore had been Vice President for both terms of the Clinton administration. Neither candidate captured Americans' imagination with a sharply defined vision for the future. Lacking what George H. W. Bush had once in frustration called "the vision thing," the campaigns of George W. Bush and Al Gore both produced ads that were largely unmemorable: The candidates squared off about social security "lockboxes," what to do with the budget surplus, and how to "restore dignity" to the White House in the wake of the Monica Lewinsky scandal. After the 2000 election, $77 \%$ of people polled in a national survey said that they did not remember any particular ad as making an impression. ${ }^{1}$ In this election cycle, $43 \%$ of ads addressed policy concerns with particular proposals. ${ }^{2}$ Interactive campaign websites played an important role in how voters received information and also in how they connected with campaigns.

Another wrinkle in this election was the surprisingly strong (for the time) challenge from the left that Ralph Nader represented. After the close election that led to the famous Bush v. Gore case and Bush's ultimate victory, Nader voters were often blamed by Democrats for putting Bush in the White House. Of course, this was not true, as many factors contributed to the

1 Darrell M. West, Air Wars: Television Advertising in Election Campaigns, 1952-2008 (Washington, DC: CQ Press, 2010), 108.

2 West, Air Wars, 51. 
narrow margin for Bush, including mistakes made on butterfly ballots due to voter confusion, votes accepted by military personnel after the absentee ballot deadline, and other unusual aspects to the election and the actual vote count. Also contributing to Bush's win were the 191,00o self-described liberal voters in Florida who voted for Bush instead of the Democratic Party's candidate. Also, it is not a given that Nader voters would have voted for Gore had Nader not run.

Education Recession

Republican National Committee

Maker: Cold Harbor Films

oo:30

Music in "Education Recession" is of a piece with several other advocacy ads bought by the Bush campaign - inspiring, positive, major mode piano music with many yearning 2-3 and 4-3 suspensions. So it may seem strange to the attentive viewer to hear such upbeat-sounding music while at the same time seeing black-and-white images and hear about an "education recession that is hurting our children." The positive-sounding music would seem to belie the negative images and $\mathrm{V} / \mathrm{O}$. The male narrator goes on to cite a statistic that US children rank last in a group of countries in tests of mathematics and physics knowledge and to cite a statistic from newspaper Education Week that "most fourth graders in our cities can't read."

So why the incongruous happy music under such sobering statistics? The answer arrives at 00:18, when the narrator talks about education in Texas under Bush's governorship. ${ }^{3}$ We see full color images of Bush giving a speech, high school graduates participating in a ceremony, and of Bush reading to African American children in a classroom. In retrospect, it is clear that the music at the beginning was anticipating the entrance of George W. Bush. It is not the most effective use of music in that it did not negatively characterize the opponent but it worked well enough to present Bush as a boon for education.

3 No Child Left Behind, a federal law modeled on Texas's example that eventually passed during Bush's administration, is now considered disastrous education policy where teachers are expected to "teach to the test." 


\section{Down}

Gore/Lieberman, Inc., 2000

Maker: The Campaign Company o0:30

Gore's ad "Down" opens with a grey-green picture of a $\$ 100$ bill and the text "The Facts on George W. Bush's \$1.6 TRILLION Tax Cut Promise." As the camera zooms out, we hear a sound effect of dripping water and see water dropping and landing on a surface with the bill disintegrating wherever the water drips. Subsequent text reads "almost half to the richest $1 \%$ " and " $62 \phi$ a day for most taxpayers." Halfway through the ad we learn the reason for the dripping water: the "trickle-down" economic theory associated with so-called "Reaganomics." All throughout the first half, we hear a low drone on $\mathrm{C}$, an ominous warning of what will happen should Bush be elected. At oo:16, it becomes clear that the ad is dual advocacy/attack. The attack having been launched, the ad turns to presenting Gore in full color as the positive figure to turn to for leadership in fighting income inequality and foolhardy tax cuts for the wealthiest $1 \%$ of the population.

Music conveys an emotional message in this fear ad. Fear in this context constitutes the lack of economic security that a Bush administration would bring and Gore is presented as the person to fill that lack.

1969

Gore/Lieberman, Inc.

Producer: The Campaign Company 01:00

Similar in tone and substance to biopics in past elections, "1969" uses a particular year in Gore's life as a pivotal moment to speak about his character. It was in that year, the narrator tells us, that $\mathrm{Al} \mathrm{Gore} \mathrm{finished} \mathrm{college} \mathrm{and} \mathrm{also}$ volunteered to serve in the Army in Vietnam (despite his father's misgivings about the war). It was potentially risky to remind voters that Gore had volunteered to serve in Vietnam, given the war's unpopularity across many spectra of American society, but a large number of those Americans who regularly vote prefer the Commander-in-Chief to have served in the military. And many people felt that members of the military were not to be blamed for decisions made by political leaders.

Music in "1969" modulates three times by chromatic mediant, the tonic pitches of the four keys outlining a diminished seventh chord: $\mathrm{Bb}$ major 
to $\mathrm{Db}$ major to $\mathrm{E}$ major to $\mathrm{G}$ major. Another political ad that modulated three times to remote keys was "Morning in America," and in both cases the key changes serve largely the same function. Modulations to distant tonal areas highlight important transitions in the voice-over text (though "Morning in America" modulations are more semiotically complex). This continual resetting of the harmonic undergirding, especially as it happens three times over the course of the minute-long ad, gives the impression of motion. Furthermore, this motion is felt in an upward direction, listeners being more likely to hear a $\mathrm{B} b$ tonic rising a minor third to $\mathrm{D} b$ (rather than falling a major sixth). When connected with positive images of a robust, young Gore, the feeling of upward motion provided by the music gives the impression a young man full of promise and desire for forward progress for society. Music tells the viewer how to feel; other elements in the ad tell her what or whom to feel it about.

The narrator speaks of Gore's military record, work as an investigative reporter, service in Congress, and finally of his marriage status and number of offspring. It's a quick "getting to know you" type of ad-a compressed version of the Bio ads of earlier campaigns, which were often over four minutes long. Cymbal crashes delineate each modulation and each modulation highlights an important point in the narrative: starting a family with Tipper-Db major; breaking with his party to support the Gulf War-E major; voting to guarantee prescriptions for seniors $-\mathrm{G}$ major. Music does its job by reinforcing important parts in Gore's life and career.

\section{Morph \\ Gore-Lieberman, Inc. The Campaign Company o0:30}

Since Ohio was considered a battleground state by both campaigns, its concerns - mainly jobs - were at the forefront of the election buildup and one ad from the Gore campaign even mentioned the state by name. As predicted, Ohio turned out to be pivotal in 2000 and a victory there would have obviated the Bush v. Gore fiasco. "Morph" is a clever ad where Ohio is gradually pulled into the form of Texas. The narrator begins the ad with "George W. Bush wants to bring his Texas ideas to Ohio." The ad attacks Bush's record as governor with regard to minimum wage, suitability of the state for rearing children, and health care. With each charge, the map of Ohio morphs gradually into Texas, nudging the surrounding states in all directions. 
Gore's premise is that Bush's record in Texas was abysmal and that he would apply the same economic policies nationally that he did in Texas, effectively transforming Ohio into Texas. Accompanying the stretching of Ohio's corners are sound effects of squeaking and slamming doors (and in the last instance, shattering glass!) — an effective use of humor. Meant to allude to Bush's association with Texas, bluesy, slow country rock music is heard from the beginning of the ad.

\section{Dangerous World \\ Bush for President, Inc. Maker: Maverick Media oo:30}

Striking about Bush's "Dangerous World," an ad meant to impress on viewers that Bush advocates a powerful military, is that the affect of the music contradicts the mood of the sound effects. A precursor to his 2004 "Wolves," "Dangerous World" has uplifting, inspiring music in A major, but with frightening sound effects. It is an odd combination. The ad starts with a violent slam to seize viewers' attention and cymbal rolls at important points in Bush's narration. Its music starts with an ostinato $A_{3}-E_{3}-G_{3}$ interlacing with a melody that gradually constructs an A major ascending scale up to $\mathrm{A}_{4}$ and then descends back down. The final figure is an A major arpeggiation back up to the high $\mathrm{A}$, coinciding with a final ascending glissando on wind chimes and a cymbal roll.

Foregrounded sounds, quite a bit louder than the music, evoke the sound effects of a horror film soundtrack while Bush speaks. Sound effects are meant to make viewers uncomfortable with the narrative voice-over giving the contextual framework in which the ad's creators wanted viewers to interpret the unease. Some of these sound effects correspond to onscreen activity while others do not. They include the initial attention-getting and difficultto-categorize "slam" (which sounds a bit like a mallet sharply striking a bass drum head, but also not like that), fingers dragging along a chain link fence, a footfall on a metal step, another slam, and a series of quick woodblock taps.

Aspirational music, which ends so hopefully on an A major arpeggio, wind chime glissando, and cymbal roll, offers an uplifting solution to the "Dangerous World": a Bush administration. Sound effects and the music dominate the discourse. Voice-over, images, and text imbue the aural elements with meaning. Sound effects, while audibly louder throughout most of the ad, are eventually overcome by the music. 
Is this an effective ad? The violent slam at the start grabs the viewer by the collar and shouts "Listen up! This is a matter of life and death!" (The attention-getting slam was a fairly recent phenomenon at that time, heard in bumpers for certain television programs such as The Dr. Phil Show.) This framing sets the stage for the underscoring that follows. When heard in conjunction with the images and voice-over, the sound effects can subtly distress the viewer. Most of the images (save the missiles and the talking head of George W. Bush), when seen in isolation from the aural components of the ad, seem innocuous: a girl playing in a dirty, abandoned industrial area that could be an airport (but it is not clear).

So the Bush campaign was playing the fear gambit already in the 2000 election, before it had the traction it would have four years later. Here is the "Dangerous World" shot sequence:

Establishing shot: Abandoned building, traffic cone lying on its side in foreground

Girl walking toward camera, high security fence in background [TEXT: Political ad paid for by Bush for President, Inc.]

Flash of "CAUTION" yellow police tape

Nighttime tracers in military video

Missile rising in the air

Bush talking head [TEXT: Governor George W. Bush]

Long shot of girl now at fence gate

Change of POV: Girl with hands on fence looks toward and beyond camera and leans into fence

Girl with only part of legs and torso and right hand visible; fingers drag along fence

Girl from new angle walking inside fenced-in area, looking out

Bush [TEXT: Strengthen Military, Restore Morale, Increase Pay]

Girl walking down metal steps

Girl on asphalt with industrial building in background

Same shot, but girl vanishes

Then establishing shot again

Girl looking downward, watching a piece of asphalt fall off a red metal ledge Asphalt piece hits the ground

Girl grasps the traffic cone from establishing shot and lifts it to upright position

[TEXT: www.georgewbush.com]

Girl running on asphalt road with field in background and airport in extreme background 
Bush [TEXT: Build Missile Defense]

Girl back at abandoned building reaches up to take the outstretched hand of Army staff sergeant in dress uniform (only his left arm is visible) [TEXT: George W. BUSH, a fresh start]

Against a partly cloudy sky, the name Bush glows and draws attention to itself out of all the text

"Dangerous World" was a strange ad that somehow fit in with the flow of political ads on television. It was not the only strange ad: Darrell M. West claims that the ad "Priority MD RNC" contained the first ever example of subliminal messaging in a presidential television ad. ${ }^{4}$ This was the ad where the word "RATS" appears fleetingly in a few frames before the RATS becomes part of the word "BUREAUCRATS." Since the text is briefly visible to the attentive viewer, this usage would not rightly be termed "subliminal." Nevertheless, the word is easy to miss unless one is paying close attention.

In 2000, the key issues were domestic ones such as social security and the economy in general as well as personal qualities such as experience, leadership, and morality (both candidates sought to distance themselves from Bill Clinton due to the Monica Lewinsky affair). In 2000, 33\% of ads dealt with character and the personal qualities of the candidate or his opponent. ${ }^{5}$ In contrast to 2004 , ads from this year seem incredibly tame and boring. 


\section{Mourning in America: 2004}

In 2004, Facebook was started by Mark Zuckerberg and other Harvard students. A coup d'état in Haiti ousted Jean-Baptiste Aristide from the presidency. NASA scientists announced findings that that seemed to indicate that water was once present on Mars. In the Darfur conflict, the Sudanese government signed a ceasefire with rebel groups. Ten new member states were welcomed into the European Union in the largest ever expansion of the organization. Massachusetts was the first US state to legalize same-sex marriage. North Korea banned cellular phones. The trial against Saddam Hussein for crimes against humanity and other crimes began. Demanding independence from Russia and the release of some prisoners, Chechen rebels took over 1,000 people hostage in what became known as the Beslan school hostage crisis.

It is difficult to imagine a starker contrast between the campaigns of 2000 and 2004. Whereas 2000 was characterized by wonky policy debates and assertions about each candidate's moral character, 2004 marked a tectonic shift in how US presidential campaigns would be conducted forevermore. In the aftermath of the $9 / 11$ attacks whose explosions were still reverberating in American ears, neither candidate could afford to scant foreign policy, in particular national security. Kerry and Bush differed in their approaches to the issue, but national security loomed largest. Thus fear was the dominant emotion in the discourse. In one way or another, most 2004 ads, whether directly or obliquely, touched this raw wound. One of the most compelling ads was forged in the furnace of American fearmongering.

\section{CASE STUDY}

Wolves $^{1}$

Bush-Cheney'o4, Inc.

Producer: Maverick Media

o0:30

In 2004 the Bush campaign ran a series of terror ads, which drew on associations with horror film music, emerged as a new genre of political ad

1 This chapter is adapted from an article I co-authored with Matthew Killmeier, "Wolves at the Door: Musical Persuasion in a 2004 Bush-Cheney Campaign Ad," MedieKultur: Journal of Media and Communication Research 50 (2011): 157-77. 
music. This was the primary innovation in political advertising in 2004. It was always clear that homeland security would be a key issue in the political discourse, and perhaps even the main issue. Even though the attacks occurred during Bush's presidency, his campaign succeeded in convincing many Americans that a second term for him would keep the United States safer than a Kerry administration would. Accordingly, the Bush campaign attacked Kerry's congressional votes and even his service record in Vietnam. If voters today remember a single campaign ad from the 2004 presidential election, it is likely to be a Bush ad entitled "Wolves" (see Figure 14.1).

This ad makes a visceral impression, and it stood out for voters during a competitive campaign. "Wolves" deftly persuades through music, ${ }^{3}$ and it hearkens to the cinematic style of "Morning in America" (though not its teleology) as well as the animal-as-metaphor-for-existential-threat of Reagan's "Russian Bear" from the same year. Interspersed through a series of disjointed images depicting a forest are brief glimpses of a wolf-its frontal gaze and a wolf passing right to left behind some trees. It is only at the end that we see a group of six wolves in a clearing. At the same time, citing a vote from 1994, a female narrator asserts that Kerry cannot be trusted with US security. But verbal description necessarily fails to convey the ad's emotional power. The premise of "Wolves" as described in words sounds convoluted and complex, but music persuades directly.

All of the music in "Wolves" is electronically generated, which lends the ad a particularly unreal or unnatural dimension (see Figure 14.1). ${ }^{4}$ These sounds are incompatible with anything one normally hears in the forest. While we might imagine musicians playing acoustic instruments in a sylvan setting, we would hardly expect to hear there music generated in a computer

2 Postelection surveys found "Wolves" to be one of the most effective and influential ads of the campaign (Lynda Lee Kaid, "Videostyle in the 2004 Presidential Advertising," in The 2004 Presidential Campaign, ed. Robert E. Denton, Jr., [Lanham, MD: Rowman and Littlefield, 2005], 296). Of all the ads aired in important battleground states, "Wolves" was the only one to have high, unaided recall (L. Patrick Devlin, "Contrasts in Presidential Campaign Commercials of 2004," American Behaviorial Scientist 49 [2005]: 287). It was also ranked the third-most influential ad in battleground states by Public Opinion Strategies (J. H. Birnbaum and Thomas B. Edsall, "At the End, Pro-GOP 527s Outspent their Counterparts" Washington Post, November 6, 2004). 3 Sometimes the lack of music and other ambient sound can be just as effective: Pat LaMarche's spots in the 2006 gubernatorial election in Maine used silence with a black screen and white text questioning the necessity of the Iraq War in order to generate a mournful atmosphere for the fallen.

4 Such electronic soundtracks are more common than music in fear ads; see Ted Brader, Campaigning for Hearts and Minds: How Emotional Appeals in Political Ads Work (Chicago: University of Chicago Press, 2006), 158. 
lab. For clarity's sake, I will refer to the acoustic equivalents of the electronic sounds; for example, I use "flute" instead of "electronic, flute-like sound."

To the viewer, music's persuasive role seems non-discursive, and thus not subject to rhetorical scrutiny. ${ }^{5}$ Music propels a story that positions the viewer as the subject of a dramatic narrative. Advertising in general has long striven to seem non-discursive, often doing so by invoking or emulating popular culture. More recently advertising's goal has been to merge with culture. ${ }^{6}$ Political advertising has followed suit.

"Wolves" can be divided into three discrete sections; its rhetorical construction justifies this approach. Each section has its own distinct rhetorical and narrative function, though with some overlap.

The transcript of "Wolves" is as follows:

\section{NARRATOR VOICE-OVER}

In an increasingly dangerous world, even after the first terrorist attack on America, John Kerry and the liberals in Congress voted to slash America's intelligence operations by six billion dollars.

WRITTEN TEXT

Kerry and liberals in Congress: intelligence cuts $\$ 6$ billion, CQ Vote \#39, '94

\section{NARRATOR VOICE-OVER}

Cuts so deep they would have weakened America's defenses. And weakness attracts those who are waiting to do America harm.

BUSH DISCLAIMER

I'm George W. Bush and I approve this message.

A strong contrast between clarity and disorientation is achieved through the ad's visual style. Clarity is established through lighting, shot distance, shot length, focus and camera movement. It is brightly lit. The shot-distances are medium and long, presenting greater visual breadth and width. Likewise the focus is sharper and deeper, enabling clearer and farther viewing. And the camera is stationary, facilitating greater visibility and a sense of stability.

The voice-over text sets the mood of fear. The phrase, "in an increasingly dangerous world," informs the audience of the context, and the trio of syllabically stressed words supports this characterization. One interpretation might construe the underscored high flute on $\mathrm{G}$ as an alarm whistle, alerting

5 J. Michael Sproule, Channels of Propaganda (Bloomington, IN: EDINFO Press, 1994).

6 See Sut Jhally, The Codes of Advertising (New York: Routledge, 1990) and Naomi Klein, No Logo (New York: Picador, 1999). 


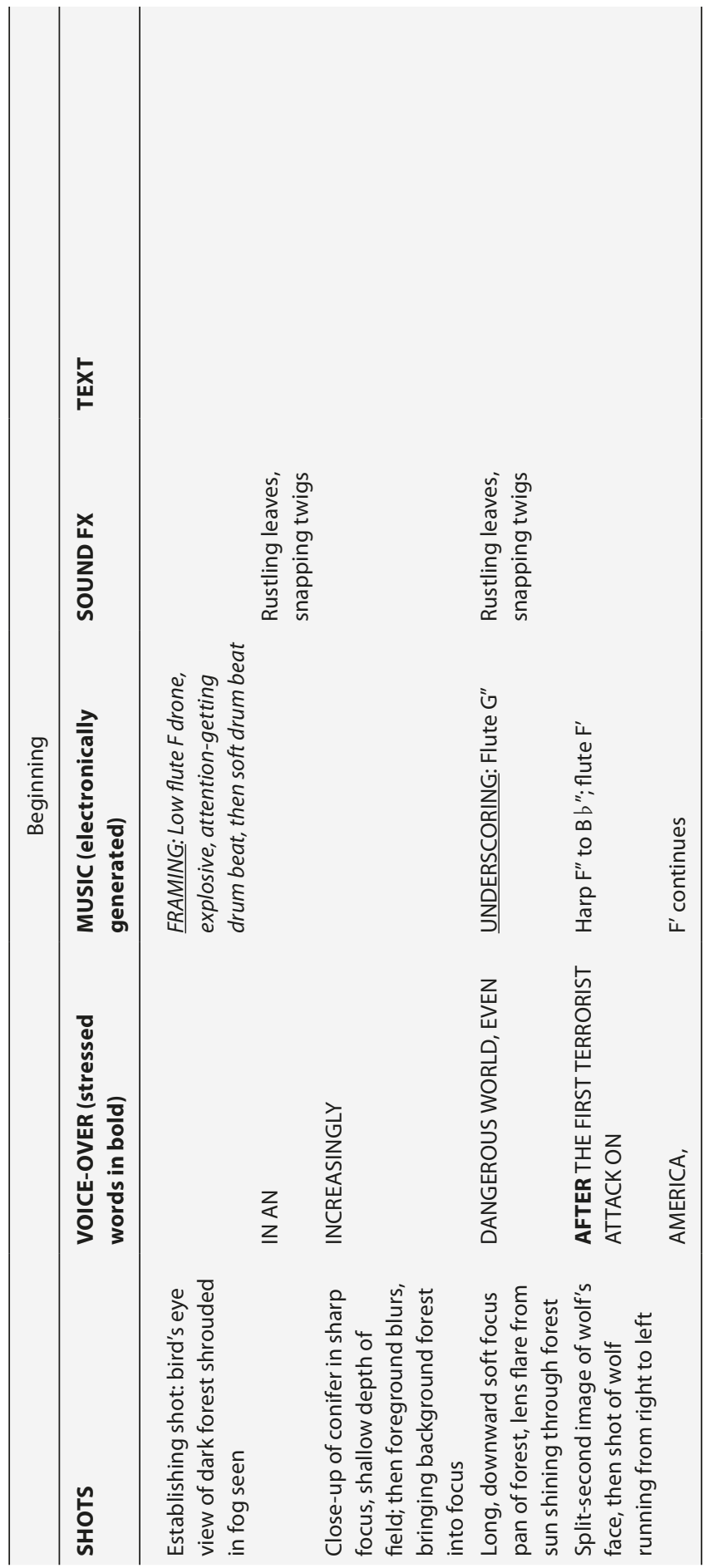




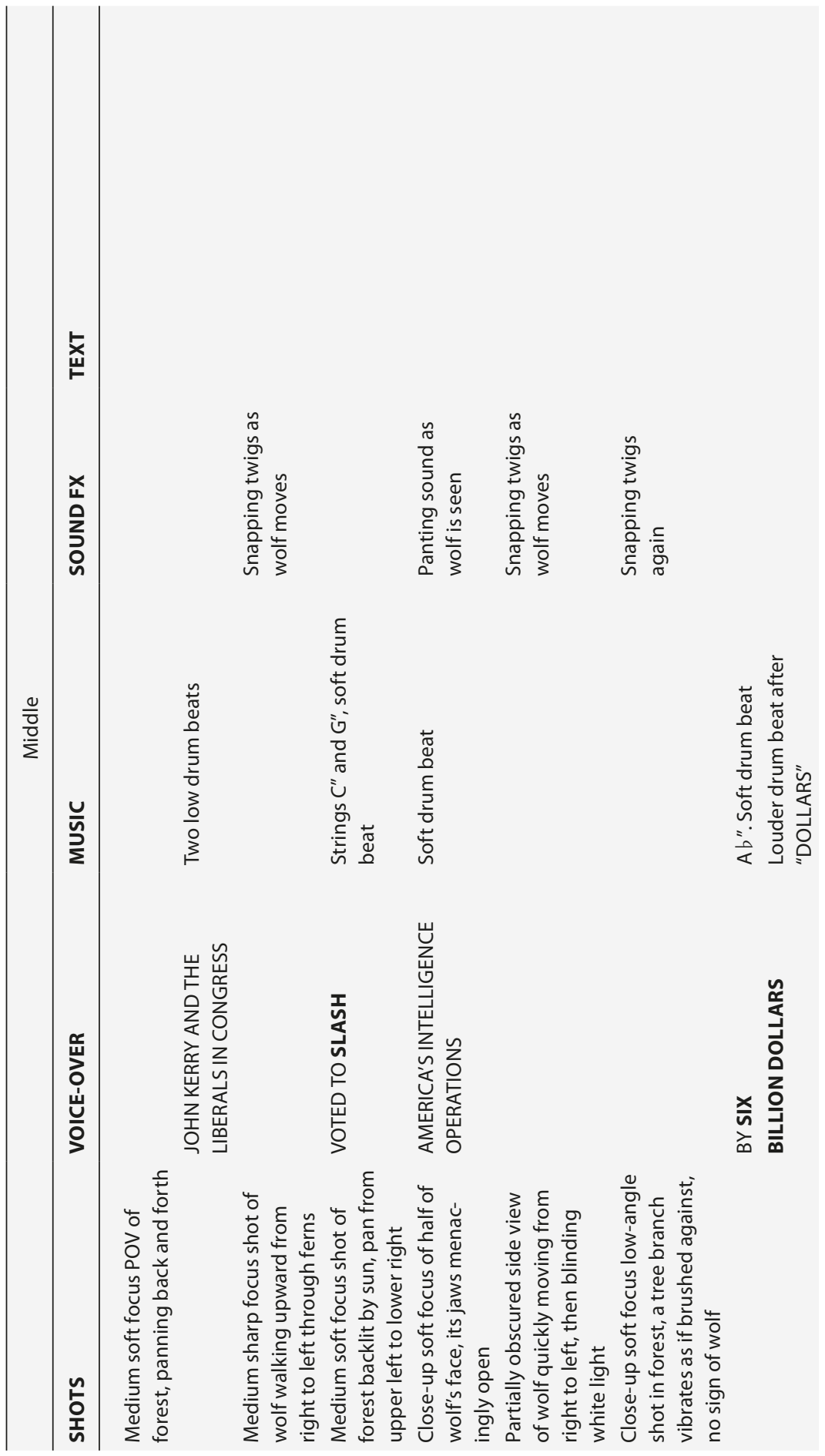




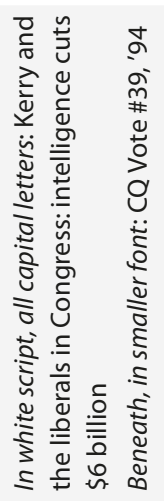

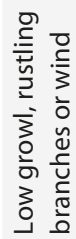

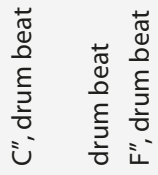
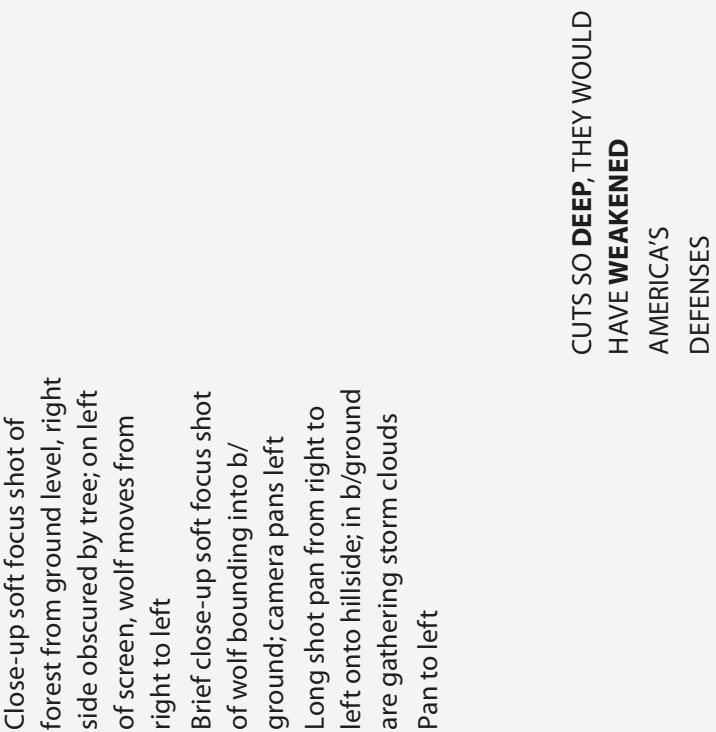


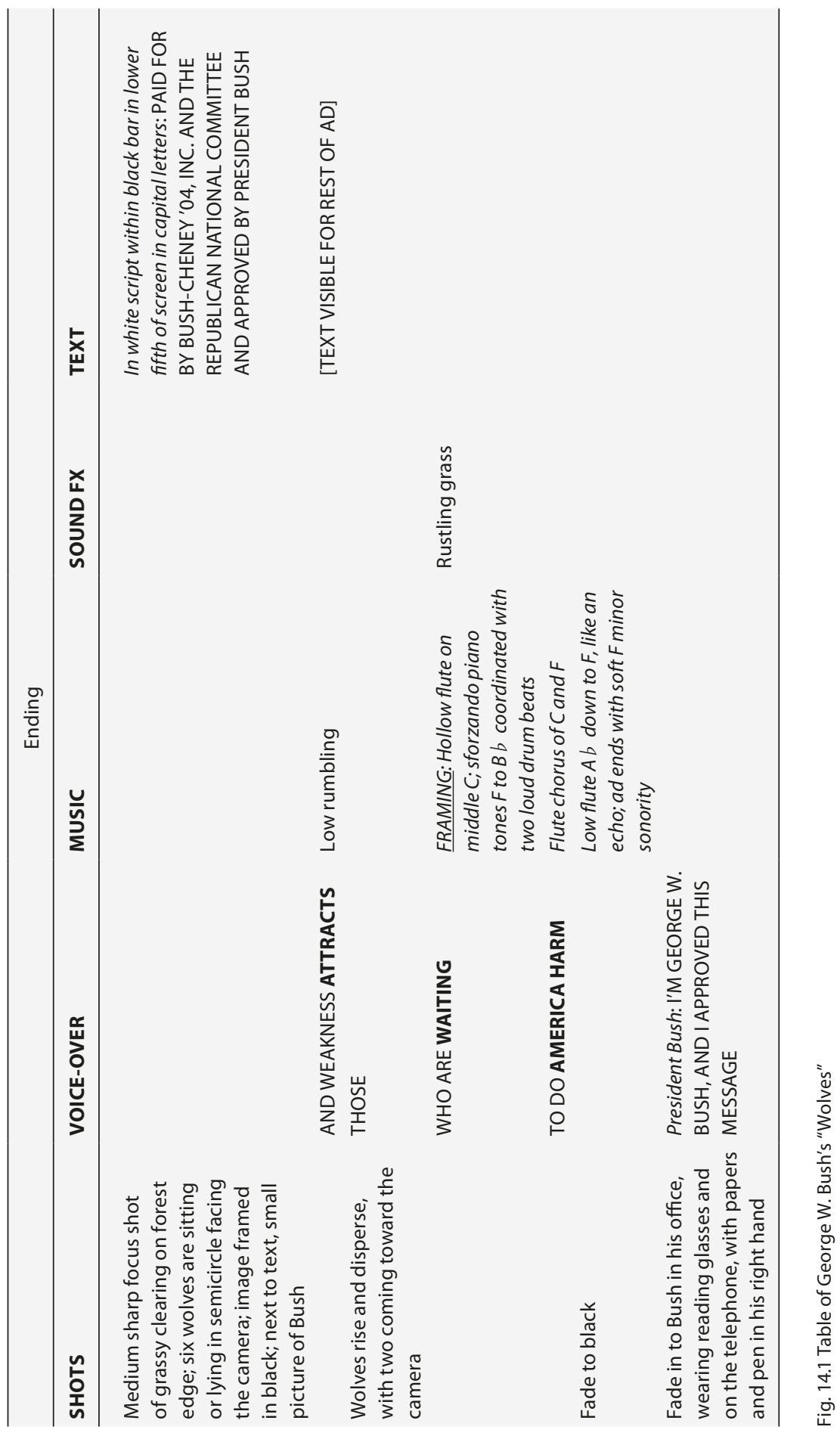


us to a danger as yet undefined. The verbal discourse promotes fear by reminding the audience of an earlier terrorist attack on the US (presumably the 1993 World Trade Center bombing). After in the phrase "after the first terrorist attack on America" receives strong syllabic stress and is underscored with an $\mathrm{F}-\mathrm{B} b$ harp gesture. This sets up the ad's verbal argument that Kerry and the liberals are reckless in their disregard for America's security. The ad implies that they ignored earlier evidence of a broader terrorist threat and thus allowed the 9/11 attacks to occur.

Likewise important is the narrator's vocal timbre. The narrator's voice furnishes the verbal discourse with substance and seriousness. Hushed delivery conveys an aural presence and proximity that complement the narrative; above all the voice is intimate. Our perception of the words is colored by the voice's immediate presence and huskiness, which convey concern and alarm. In conjunction with the music, the voice-over inflects the soundscape with a sense of foreboding and darkness. ${ }^{7}$

Gender constitutes a key component of the voice's texture and its effect on us; its female gender evokes the uncanny. ${ }^{8}$ For Sigmund Freud, ${ }^{9}$ the unheimlich (uncanny) is an impression associated with things simultaneously familiar and strange. The ad's voice-over is disembodied and female. ${ }^{10}$ Disembodied female voices in audiovisual texts are especially uncanny for audiences accustomed to seeing the woman's spectacular body. ${ }^{11}$ Unlike men's voices, which are routinely disembodied, women's voices are rarely discorporated.$^{12}$ Lacking body, a female voice-over violates audience expectations of the familiar. This absence is at once both familiar and strange. Similarly, a female announcer can signify the "weaker sex," which may work to intimate vulnerability in the context of a homeland threat.

7 While the narrator has a distinct voice, she is anonymous as in all of Bush's attack ads. In contrast, Kerry made the attack himself in thirty percent of his negative ads (Kaid, "Videostyle in the 2004 Presidential Advertising," 289).

8 In his analysis of campaign ads from the year 2000, Ted Brader found that female narrators were used in fear ads by a two-to-one margin (p. 163).

9 Sigmund Freud, "The Uncanny," in The Standard Edition of the Complete Psychological Works of Sigmund Freud, ed. James Strachey (London: Hogarth, 1955), 217-55.

10 Gender is at the core of Freud's conceptualization of the uncanny. The ultimate source of the uncanny is woman, more specifically the vagina and womb. They are familiar in that we biologically originate from them, and strange owing to our identification with the phallus. See Freud, "The Uncanny," 217-55.

11 Kaja Silverman, The Acoustic Mirror: The Female Voice in Psycholanalysis and Cinema (Bloomington: Indiana University Press, 1988).

12 As Allison McCracken notes, disembodied female voices provided particularly uncanny and suspenseful affect in radio (Allison McCracken, "Scary Women and Scarred Men," in Radio Reader, eds. Michelle Hilmes and Jason Lovoglio [New York: Routledge, 2002], 183-207). 
Such familiar gender connotations may appeal to conservative voters and resonate with their perception of "traditional" gender roles and difference. The narrator might conjure the patriarchal ideal of home/heimlich (and its associated term in this context, the homeland), as well as the threats to it the ad invokes - the unheimlich manifested in the wolves. ${ }^{13}$

In ads music often works as mythology does. Roland Barthes coined the concept of "mythologies" to describe the ways signification works in media-saturated societies. ${ }^{14}$ Barthes noted that established signs, the result of what he called first-order significations, could be drawn upon and used as signifiers in another (second-order) signification. In the context of music, Nicholas Cook suggests that music is effective in constructing mythologies in television ads. ${ }^{15}$ It is a second-order signifier that brings attributes into the ad, but is also affected by the other (verbal, aural, and visual) signifiers.

Like music, metaphors can condense a great deal of meaning into concise figures. Metaphors translate complex entities (world, threats) into simple, primal things. ${ }^{16}$ The two key metaphors in the ad are the wolves and the forest. ${ }^{17}$ Wolves tap familiar narratives drawn from folk and fairy tales and a deeper reservoir of difference between nature and culture. Wolves are "terrorists" of a different stripe familiar to us in "Little Red Riding Hood" and "The Three Little Pigs." Forests are a familiar setting in such tales, underpinning American foundational mythologies such as the need to tame the wild. The woods also serve as a metaphor for new twenty-first-century geopolitical configurations, such as the so-called global war on terror, and more generally the largely unknown world outside the "homeland." In the ad, the world is "increasingly dangerous. ${ }^{13}$

13 The use of a female announcer was strategic, too. The campaign constructed and refined the ad to appeal to women aged thirty-five and older, and focus groups showed women responded more strongly than men (Kathleen Hall Jamieson [ed.], Electing the President 2004 [Philadelphia: University of Pennsylvania, 2006], 83).

14 Roland Barthes, Mythologies, trans. Annette Lavers (London: Paladin, 1971).

15 Nicholas Cook, Analysing Musical Multimedia (Oxford: Oxford University Press, 2001).

16 George Lakoff and Mark Johnson, Metaphors We Live By (Chicago: University of Chicago Press, 1980).

17 Bush media consultant Alex Castellanos produced the ad and based it on "a metaphysical idea that would represent the threat of the war on terror ... when we tested Wolves, people got it immediately. 'Wolves, terrorists, we got it, threat, yep'” (Jamieson, Electing the President 2004, 49). 18 Castellanos summarized the ad as: "Terrorists were wolves, renegades, chaotic and unpredictable enemies that lurked in the shadows and could strike any moment" (Jamieson, Electing the President 2004, 83). 
Throughout the ad the viewer is disoriented and vulnerable, moving from a position of power to one of weakness. The ad's establishing shot is over the forest, well above the treetops. The viewer has scopic power, but this quickly diminishes in the second and third sequences. With the fourth shot our position is reversed-now we look up at trees from below. In the fifth shot we see a wolf for the first time, but because it is so brief and the wolf is moving, we are not sure what we see. Retroactively —in the middle segment—we realize what it was. Metaphorically, we are disoriented and threatened prey.

This narrative should be familiar to audiences as it includes most of the elements of a generic horror plot. Noel Carroll argues that horror plots include the following elements: onset, discovery, confirmation, and confrontation. ${ }^{19}$ "Wolves" contains the first three and implies the fourth. The beginning of the ad serves as the onset retroactively, where the "monster's presence [is] established." ${ }^{20}$ The beginning shows us quickly becoming vulnerable, disoriented, and conveys how we should feel about it. "An increasingly dangerous world" makes a claim verbally, but also registers affectively. This segment establishes where we came from, and where we are now. We had dominion over the forest (geopolitical world) with clarity, but shortly after getting our bearings from the establishing shot, we are quickly plunged into the dark, disorienting woods, into a position of weakness and limited view. We catch a glimpse of something moving near us. We've lost our visual acuity and dominant position. We are not alone.

The establishing shot presents a low $\mathrm{F}$ drone in a flutelike timbre, combined with an explosive, attention-getting drumbeat, followed by a softer drumbeat. Setting the tone for what is to follow, this frame evokes unease. Taken with the intense and hushed voice-over and the confusing, mysterious images, which both support the music's frame, the overall effect is chilling and foreboding. With the phrase "dangerous world," flute on G is heard, and an $\mathrm{F}-\mathrm{B} b$ leap in harp sounds on the phrase "after the first terrorist attack on America."

In comparison to the beginning and ending, the middle of the ad is visually disorienting. The lighting in most shots is chiaroscuro, primarily dark, at times accentuated by brighter backlighting from the sun, ${ }^{21}$ impairing

19 Noel Carroll, The Philosophy of Horror (New York: Routledge, 199o), 99.

20 Carroll, The Philosophy of Horror, 99.

21 According to Castellanos, the sky in the establishing shots was darkened, "to portend the gathering storm and [we] darkened the rest of the shots" to enhance the perception of a "dark moment before a terrorist attack" (Jamieson, Electing the President 2004, 83). 
visual clarity and depth and establishing a fearful mood. Shot distances are close, which cultivates a claustrophobic visual sense that interacts with the fearful mood and disorientation. Shot durations are very short in the middle; the bulk of the cuts occurs here (ten out of sixteen), and the viewer is unable to firmly situate her gaze and temporal grounding. Accelerating the pace of the ad are rapid cuts that contribute to "surprise, horror, and disruption. ${ }^{{ }_{22}}$ Visual disorientation begins to nudge viewers toward panic. The shot focus is soft and blurry, and the camera moves a great deal, like a person searching. This blurs the focus further, increasing the sense of disorientation and panic.

The verbal discourse builds upon the characterization of growing threats (and the implication of Kerry's lack of concern), advancing it further by informing us that Kerry and the liberals wanted to cut intelligence funding. Syllabic stress and underscoring undergird this claim: John Kerry, liberals, Congress, slash, six billon dollars, cuts, deep, and weakened are all emphasized. Slash, six billion dollars, and weakened receive the strongest stress. Viewers are likely to remember the claim through repeated exposure. Furthering the stress on this information, this part of the ad is the most percussively underscored part of the voice-over. Drumbeats occur after liberals and Congress, and America's, and they precede each word in the phrase six billion dollars. And varied drumbeats follow each word in the phrase weakened (soft) America's (loud) defenses (soft). This underscoring amplifies the voice-over stresses and adds gravity to the message.

Disorientation and panic increase in this section of the nonverbal discourse. The camera is nearly always moving, there are the many cuts and short shots, the lighting is consistently chiaroscuro, and the focus soft. Significantly, a wolf appears, with only close-up shots following except for the final sequence. Our confirmation is enhanced as we also hear its panting. As a generic horror plot, the middle section combines onset (retroactively), discovery, and confirmation. Discovery is where "after the monster arrives, an individual or group learns of its existence. ${ }^{{ }^{23} 3}$ We discover the wolves in the woods. Our anxiety increases with the clear, close images of the wolves, our position is consistently weak (low), and viewers' gaze moves about searchingly. Confirmation "involves the discoverers of or the believers in the existence of the monster convincing some other group of the existence of the creature. ${ }^{, 24}$ Confirmation is achieved through increasing 
encounters with the wolf, the insinuation that Kerry and the liberals are oblivious, and by implication that Bush can protect us. In sum, we have discovered and confirmed that wolves abide in the woods with us. Viewer disorientation is lessened as the threat is identified. However, our sense of fear and panic increases because it is a savage, ruthless threat. By the end of the segment, viewers are ready to protect themselves from a confirmed existential threat. This narrative knowledge complements the framing of Kerry and the liberals as feckless. At the end of the segment, viewers' gaze turns to a clearing that opens up.

Carrying over from the beginning, we hear underscoring with "John Kerry and the liberals in Congress": a low drumbeat, followed by another on "voted to slash" and a soft and then loud drumbeat on the phrase "by six billion dollars," coinciding with $\mathrm{A} b$. Three successive drumbeats are heard, along with flute $\mathrm{C}$ and $\mathrm{F}$, on the phrase "cuts so deep, they would have weakened America's defenses."

Underscoring in this ad is almost Webernesque in its pointillistic economy of sound. Various musical components foreshadow the ending. The F minor scale is gradually built throughout the ad: First F, then G, followed by $\mathrm{B} b$ and $\mathrm{C}$, and then the pentachord is filled in with $\mathrm{Ab}$ on the phrase "by six billion dollars." In the subsequent phrases "cuts so deep, they would have weakened America's defenses," $\mathrm{C}$ and $\mathrm{F}$ complete the $\mathrm{F}$ minor chord. (All of these tones are accompanied by drumbeats powerfully punctuating the voice-over text.) The dark minor mode confirms the ad's ominous implication: Americans are vulnerable to imminent attack. Introduced in the middle, the F minor sonority is present in the ending, as are the drumbeats that have obsessively accented specific voice-over words.

In the ending, clarity emerges. While the viewer welcomes the newfound clarity, she despairs to see the revealed wolfpack in a clearing. The wolves are at eye level, the most equalizing angle. They are lit brightly and evenly, with clear focus. Viewers now can clearly see that we face not one wolf, but a pack, a "gathering threat" (as Bush described Saddam Hussein prior to the 2003 invasion). The wolves rise and disperse as the deal is clinched on the emotional appeal. We wonder where they are going ...

The verbal discourse links Kerry and the liberals with weakness, claiming that their votes weakened America's defense. An assertion that weakness entices terrorists to attack gives this information context. Strong syllabic stress is placed on: Attracts, waiting, America harm. As in the middle, the inflected words serve a mnemonic function; the message will resonate after details are forgotten. Music again frames in the ending. The most powerful stress of the whole ad is on waiting. The word is emphasized 
musically (flutes and drumbeats) and by the ensuing stark silence. The word is pregnant with meaning: the US could be attacked at any moment. Complemented by horror genre music, this is the climax of the ad. The phrase America harm is framed by a middle range flute $\mathrm{A} b$ and $\mathrm{F}$ that punctuates it at the very end (exclusive of the disclaimer).

The dénouement of "Wolves" completes confirmation of the threat by showing us the gathered wolves. And it implies an inevitable confrontation, whereby "humanity marches out to meet its monster." ${ }^{25}$ The wolves coming toward us invite confrontation, as does the implied message of difference between Kerry and Bush. Implied confrontation is another persuasive message that complements verbal framing forwarded by the Bush campaign (but not explicitly articulated in "Wolves"): The United States must be on the offensive. The ending ties the segments together effectively. We've been thrust into disorienting, dangerous woods in which stealthy threats are within earshot and all around us. Some authorities are weak and their actions (or inaction) endanger us. Worse yet, weakness attracts the wolves, which are gathering to do us harm. We are primed to demand assertive security. We are left to complete the enthymeme, to infer the message of the parable. ${ }^{26}$ Bush campaign media consultant Alex Castellanos said that the last shot was constructed to be open-ended and provocatively suggestive. "The wolves are going somewhere. Where are they going and why? I wanted to leave the end of the spot inconclusive." We need strong authorities to protect us, authorities who see the danger of the woods and the threatening wolves within.

In the final sequence, numerous elements come together to bring closure. After the voice-over "who are waiting," we hear a brief pause, a sort of musical colon, demanding that we pay close attention to what follows. Then there follows a sforzando $\mathrm{F}-\mathrm{B} b$ piano figure, a hollow flute chorus on $\mathrm{F}$ and $\mathrm{B} b$, and a low flute $\mathrm{A} b-\mathrm{F}$ (like an echo). Here the $\mathrm{F}$ minor tonality, merely hinted at in the middle section, comes together most convincingly. Harmonically, dynamically, and timbrally, the music in the final seconds of the ad brings together all of the frightening and uncanny elements from the beginning and middle sections. And while the beginning is chilling, the ending is harrowing and terrifying.

The viewer's position as prey is evident in the final scene with wolves dispersing. It bears repeating that whereas the voice-over text, images, and sound effects unsettle the viewer, it is music that clinches the deal in the 
ending. Without it, the ad would scarcely persuade. The series of confusing images of the forest and of one wolf and subsequently six wolves, along with the voice-over, would strike the viewer as absurd or nonsensical.

A coda ends "Wolves." In the form of a disclaimer that comports with campaign finance regulations, it provides resolution for the problem constructed in the ad. It seems crafted specifically for "Wolves." Likewise, the disclaimer's positioning differs from that in other Bush ads. According to Castellanos, where to place the legal disclaimer-at the beginning or ending - was contentious within the campaign. Castellanos thought the disclaimer should come at the beginning, believing that such placement is more effective in ads that appeal to emotion. ${ }^{27}$

The disclaimer depicts Bush wearing reading glasses and speaking on the telephone, holding papers and a pen. He seems hard at work. Visually the disclaimer mirrors the ending. It is brightly lit, the camera is stationary, and the muted colors carry over. Images of the threatening wolves are juxtaposed against the image of Bush working, comfort after fear. While the disclaimer lacks music, the closing music in the ending and the pregnant pause after "waiting" resonate here. Throughout the entire ad, music generates a frightening mood, and the disclaimer portrays Bush as a superior alternative to Kerry. Bush's voice-over-“I'm George W. Bush and I approve this message" - offers reassurance.

Though a solution is not explicitly offered, the disclaimer strongly implies it. Implication makes the persuasion stronger than bald assertion. Viewers are rhetorically guided to compare Kerry unfavorably with Bush. Of course such contrasts are always implied in negative ads, but "Wolves" uses the disclaimer determinatively. The audience is led to complete the enthymeme by concluding that Bush will protect the US from unknown and ever-present terrors. The ad conveys the impression that the viewer has reached this conclusion on his or her own.

Music in "Wolves" is not meant to be noticed; rather, it acts surreptitiously. Musical arguments in "Wolves" function narratively through means we are ill-equipped to scrutinize. Persuasion is dialogic, reciprocal, interactive, transactive, dialectical, and involves a co-creation of meaning, ${ }^{28}$ but propaganda manipulates through stealth and through the use of techniques of nonverbal discourse deployed to elude logic and reflection. Propaganda

27 Jamieson, ed., Electing the President 2004, 82.

28 Garth S. Jowett and Victoria O'Donnell, Propaganda and Persuasion, $4^{\text {th }}$ ed. Thousand Oaks, CA: Sage, 2006. 
is monologic, from one to many; it facilitates top-down "management of public opinion.". ${ }^{29}$

The use of electronic sounds further distances the music from attempts at analysis. The climax at the voice-over word "waiting" brings the ad together. The music is the loudest and most suspenseful at this point, and it punctuates "Waiting" with a loud, dissonant chord that is followed by silence intended to highlight the most important message of the ad: "to do America harm." The narrator's tone and the images of scattering wolves that ensue together create a powerful call to arms that we are compelled to heed.

In the following chapter we will examine a number of other ads from the 2004 campaign, ads that span many different genres and styles. 


\section{Whatever It Takes: 2004, continued}

The year 2004 was so rich in political ad music that it demands another chapter. For some reason, this year presented viewers with an embarrassment of riches with regard to music in political ads. Variety and creativity is most evident in Republican ads; the Bush campaign in particular commissioned many ads where music is prominent, even central— "Wacky," "Whatever It Takes," "Windsurfing," "Wolves" (and in other ads whose titles do not begin with the same letter as Bush's middle initial).

\section{Whatever It Takes}

Bush-Cheney'o4, Inc.

Producer: Maverick Media

01:00

Feeding into the same terror framework that gave birth to "Wolves" is "Whatever It Takes." This ad presents George W. Bush as a quasi-messianic figure. Intended to make audiences identify positive feelings with Bush, the music matches the narrator's text line by line. Here is the transcript:

[BUSH] These four years have brought moments I could not foresee and will not forget. I've learned firsthand that ordering Americans into battle is the hardest decision, even when it is right. I have returned the salute of wounded soldiers who say they were just doing their job.

I have held the children of the fallen who are told their dad or mom is a hero but would rather just have their mom or dad. I've met with the parents and wives and husbands who have received a folded flag. And in those military families, I have seen the character of a great nation. Because of your service and sacrifice, we are defeating the terrorists where they live and plan and you're making America safer. I will never relent in defending America, whatever it takes. I'm George W. Bush and I approve this message.

For most of the duration of the ad, the key is $\mathrm{C}$ major, with fleeting feints to the relative minor at particularly emotional points. Phrases start and end on the dominant, and deceptive cadences punctuate phrases. The relative minor is deployed for particular effect: for instance, on the words "ordering Americans into battle is the hardest decision" and the words "but would rather just have their mom or dad" ( $\mathrm{V}^{6} / \mathrm{vi}$ goes to vi). At the phrase "I have 
seen the character of a great nation," marked by a bridge, an oboe is added for heart-warming effect. A sweeping crescendo, a thunderous cymbal crash, and a key change to II (D Major) at the end at Bush's forceful statement "I will never relent in defending America, whatever it takes" inject the ad with an extra dose of sentimentality. All of the above connections are examples of how the music and text were written to coincide line by line.

Throughout the ad, emotions are pride and perseverance. Bush has "learned firsthand" that war "is the hardest decision, even when it is right." This second line sets the pattern of the weaving of political arguments and sentiment. Bush asserts that the war was just, that it has entailed sacrifices that are necessary, and because of them the United States is winning and increasing its security. And that he is resolute. The ad implicitly recognizes the toll of war and preempts criticism that Bush is oblivious or uncaring to suffering caused by war, not with an argument, but through emotion. Viewers are called to identify with the universal human through the generic anecdotes of the pain of loss. We see images of real people displaying patriotic fervor, mourning, and stoicism.

The music is contextualized by the images — individual and nation, leader and led, soldier and unit. "Whatever It Takes" offers audiences emotional identification; we feel the loss, sacrifice, common stoic humanity, and greatness of the nation through music. Simultaneously we see images moving between leader and collective nation that are reminiscent of Triumph of the Will. Finally, Bush asserts the leader's resolute commitment to defending the nation, while acknowledging the pain and sacrifice entailed, but importantly linking that sacrifice to victory, giving it greater meaning and profundity. While viewers might not agree with the arguments overtly made, they likely feel the pain of sacrifice and are able to link it to exceptionalist myths (that wars are always defensive, they are always undertaken for noble reasons, the US has a special role/responsibility in the world, etc.).

\section{Finish It}

Bush-Cheney'o4, Inc.

Progress for America Voter Fund

o0:30

Over pictures of known foreign terrorists, "Finish It" starts with the narrator stating flatly, "These people want to kill us." This message is hard to misinterpret. The ad begins in D minor, with the first four notes of the Dies irae (see Figure 15.1). (This fact will be missed by the vast majority of viewers, 
but for those who catch the reference, an extra connection is made that can potentially increase the ad's power.) There is a $\mathrm{i}-\mathrm{V}$ - I harmonic progression under a natural minor scale descent in the melody, which ends the first section of the ad on a stark, low D at the text "Would you trust Kerry?" as the narrator says "Would you trust Kerry up against these fanatic killers?" A tierce de Picardie ends the ad with a picture of George W. Bush, soldiers, and the American flag, and the shift to major mode harmonically assures us "All will be well if you vote for me."

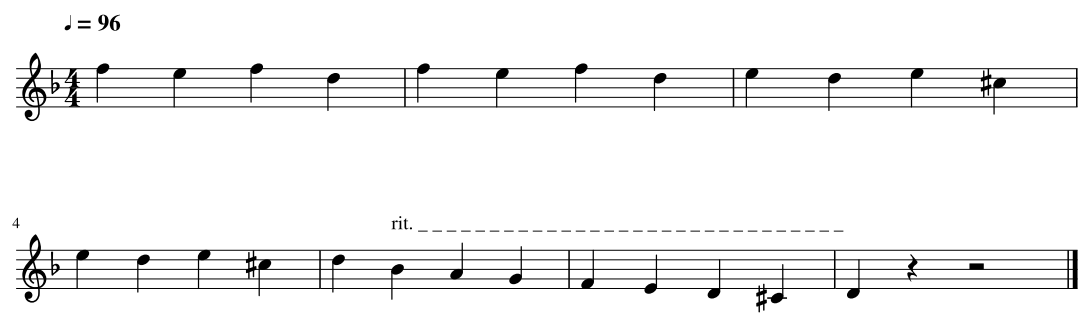

Fig. 15.1: Melody of Bush's "Finish It"

The word "innocent" receives a lot of stress throughout the ad, emphasizing the victim status of Americans in an ongoing struggle as we are asked by the narrator, "Would you trust John Kerry up against these fanatic killers?" (heard as we see masked terrorists followed by a black screen). Slogans of several Bush ads in 2004 seem to form part of an intertextual web of meaning: "Victory," “Finish It," “Whatever It Takes," "Any Questions?" This web was woven by the Bush campaign the Progress for American Voter Fund, the British media production company Maverick Media, and other, more shadowy, entities.

Portraying viewers as potential victims of horrifying violence-should they choose to vote for the opposing candidate - is the chief fear appeal. The final scene with Bush is in color, in major mode, and asserts that Bush will finish the war started by the terrorists. (This might ring true for men who were told as boys by their fathers not to start playground fights, but to "finish them.")

"Finish It" was an effective ad, but not because it supplied useful or reliable information to voters. In fact, the untruths contained therein provided fodder for a FactCheck.org article entitled "The 'Willie Horton' Ad of 2004?" Neither this article nor any other public criticism of "Finish It" or the general tenor of the Bush campaign attacks prevailed-large numbers of voters still seemed to not trust Kerry on his ability to deal with terrorist threats to the homeland. 
Bush's ad convinces because of its mournful music. Images give the music something to attach to, but music sounds funereal (except for the happy disclaimer). Besides Bush at the end of the ad, the faces we most remember are those of Mohammed Atta, Osama bin Laden, Khalid Sheikh Mohammed, and John Kerry-most assuredly not the company Kerry would wish to be associated with. In two separate stills, he has an expression that might suggest that he is dubious of or indifferent to any terrorist threats. Of course, these appeals rely for their strength on their unstated nature. Were such associations made explicit-“Doesn't he just look unprepared to deal with terrorists?" - they would seem prima facie absurd.

\section{Sellout \\ Swift Boat Veterans for Truth 2004 Stevens, Reed, Curcio and Potholm 01:00}

Since Kerry had served in active duty in the Navy during Vietnam and Bush had only served in the Texas Air National Guard (and because some people had alleged that he went AWOL for part of his tour), the Bush camp felt it necessary to attack Kerry's service record since national defense and security was the centerpiece of their campaign. For his actions in the Vietnam conflict, Kerry had been awarded three Purple Hearts and a Bronze Star and a Silver Star. In September 2004, the conservative group Judicial Watch requested an investigation into whether the combat medals were properly awarded in accordance with military procedure, but the effort was in vain: the Navy Inspector General found no irregularities in the processes that led to Kerry's decorations. Nevertheless, the act of merely raising such questions did its own work.

A Republican-funded group called Swiftboat Veterans for Truth produced a series of ads meant to undermine Kerry's military reputation. Although numerous news outlets found that the allegations were false, the ads did their job of raising reasonable doubt in some voters' minds. It has been suggested that there was a fair amount of coordination between the Bush campaign and SBVT. ${ }^{2}$ Of course, the campaign distanced themselves from

2 See, for example, Kate Zernike and Jim Rutenberg, "Friendly Fire: The Birth of an Attack on Kerry," New York Times, August 20, 2004, http://www.nytimes.com/2004/08/20/us/the2004-campaign-advertising-friendly-fire-the-birth-of-an-attack-on-kerry-html?_r=o (accessed August 31, 2016); Joe Conason, “Republicans' Dishonorable Charge," Salon, August 6, 2004, http:// 
the ads. "Sellout" is one of the infamous and reviled Swiftboat ads. Reviled, but effective.

This ad uses melancholy guitar music in D minor. Perhaps most prominent in this ad is a descending tetrachord ostinato in the bass: $\mathrm{D}-\mathrm{C}-\mathrm{B} b-\mathrm{A}$. This trope has a long history of symbolizing musical lament and melancholy, beginning in the early seventeenth century. It symbolized most graphically tears falling down cheeks. ${ }^{3}$ Ostinati, exact musical reiterations, reinforce the repetitive nature of the testifiers' claims. Viewers get the impression that it is not just a couple of enemies of Kerry speaking against him or a few politically motivated attackers, but rather a consistent story shared by numerous veterans who served with Kerry. The mourning aspect of the ad refers not to the heinous acts committed by some soldiers (about which he testified before Congress), but rather to the "sellout" that the veterans accused Kerry of committing.

\section{Wacky \\ Bush-Cheney'o4, Inc. \\ Maverick Media \\ 00:30}

Music in this sepia-toned, Charlie Chaplin-style ad works as a signifier of genre and provides semiotic codes that imbue it with significations that help construct a musical argument complementing the ad's verbal, logical argument. Genre is understood here, in a general sense as shared conventions and framing orientations. As shared conventions, genres allow producers to quickly signify and audiences to efficiently interpret the ads. Likewise framing orientations are fastidious and articulate popular, generic conventions with ideological discourses. Language is recognized as facilitating framing by dictating the terms of debate in popular, political discourse, with words and phrases strongly coloring perceptions of candidates and issues. "Wacky"

www.salon.com/2004/08/o7/mccain_on_swift_boat_veterans/ (accessed August 31, 2016); and Eleanor Clift, “Capitol Letter: Fighting a Phony War," Newsweek, August 19, 2004, http://www. newsweek.com/capitol-letter-fighting-phony-war-125999 (accessed August 31, 2016).

3 Geoffrey Chew, "Monteverdi, Claudio: Works from the Venetian years," Oxford Music Online, ed. Laura Macy (Oxford: Oxford University Press, 2008). Alex Ross, in "Chacona, Lamento, Walking Blues: Bass Lines of Music History," the second chapter of his book Listen to This, $3^{\text {rd }}$ ed. (New York: FSG, 2010), discusses the quasi-universality of a descending tetrachord for expressing sorrow musically.

4 George Lakoff, Don't Think of an Elephant!(White River Junction, VT: Chelsea Green, 2004). 
builds upon the verbal framing of the appellation "liberal" that has been ongoing since the late 1970s. The discursive connotations that have framed "liberal" are assumed and provide the base for the connotations that "Wacky" has.

There is simply too little time in a television commercial to outline a complicated argument. Music must work in caricatures and stereotypes, which is to say, it works generically. It also works generically by evoking familiar styles and making references or allusions, necessary in a thirtysecond ad where time is expensive. Music in "Wacky" is of a distinctly early twentieth-century cast. We might find this type of music in silent films, which the visual composition of the ad attempts to invoke. The rhythm is straight, though syncopated, the type we might find in ragtime. In "Wacky," the shared generic conventions and familiar style help facilitate the ad's chief frame: the distant past.

Like photographic captions, music helps to delimit the potential connotations of the images of TV ads. In "Wacky," the music aids in pinning down the time. The juxtaposition of images from different time periods-digital and analog gas pumps, Bush and Kerry with men from the early twentiethcentury and a woman whose hairstyle and brassiere are postwar, and intertitles, sepia tones, and a hand-cranked camera showing a Chaplin-like tramp that allude to silent film with a voice-over-connote several time periods and are potentially confusing. This is somewhat mitigated by the ad's monochromatic palette, although twenty-first-century images (digital gas pump, Bush, and Kerry) are still incongruous.

All signification is predicated upon difference-things only convey meaning differentially, ${ }^{5}$ and music aids in this ad's paradigmatic connotations. The music in combination with the visuals, references the past of the silent film era and suggests some of this idiom's genres, specifically the early narrative comedies (Keystone Kops, slapstick, Charlie Chaplin). Musically and visually, the ad is upbeat and comic, and these connotations are partly derivative from their differential comparisons. The ad is neither reverential like "Whatever it Takes" nor horrifying like "Wolves." More concretely, as the music denotes the early twentieth-century past, it also implies what it is not: the present. Furthermore, "Wacky" alludes to other associated connotations about the past: it is anti-progressive (as history is popularly perceived as a progressive narrative); it is humorous; and it implies that the viewer is modern and progressive and should not identify with Kerry. These associated connotations evoked by the music and images

5 Ferdinand de Saussure, Course in General Linguistics, reprint from 1916 (New York: Philosophical Library, 1959). 
are powerful emotional arguments that are much stronger than the rather limited verbal argument about gas taxes.

Musically, what comes first sets up and implies what follows. Its primary melody is a banal pentatonic tune in $\mathrm{F}$ with one chromatic inflection (Ab as A descends to G). During the second statement of this theme, the violin and clarinet play complementary countermelodies. Oddly, the music just "spins its wheels" in a series of half-cadences, but that is the point: Music that does not go anywhere is appropriate in an ad attacking one's opponent for being mired in the past. ${ }^{6}$ And it complements the linguistic framing of the "liberal" appellation, as well as illustrating an effective trope for "othering” one's opponent. The Bush-Cheney campaign through music is trying to show Kerry as unable or unwilling to abandon his old wacky ideas. Because no resolution is offered in the continual stream of phrases ending on the dominant, the viewer is not particularly startled when the music is clumsily spliced together to fit a concluding perfect authentic cadence in the tonic in the final few seconds of the ad.

\section{Windsurfing \\ Bush-Cheney'o4, Inc. Maverick Media \\ oo:30}

"Windsurfing" begins with the Bush disclaimer. This allows the comic character of the ad to remain in viewers' minds at the end. Already the ad enjoys an iconic status among political advertisements. Its humor immediately appeals. Its elegant simplicity makes it truly one of the most powerful in recent memory.

This ad accomplishes so much at once, in a way strikingly similar to George H. W. Bush's “Tank Ride," which took Michael Dukakis's photo opportunity and turned it against him (see Chapter 10). "Windsurfing" shows Kerry doing something frivolous, engaging in a sport seen by many as elitist (and somehow European?). Some might even consider his swimming gear mildly effeminate. The editing, making Kerry windsurf back and forth - making no progress, it is implied-lends the candidate a comical air. If, instead of inviting reporters to Nantucket to watch him windsurf,

6 This is a point Edward Said makes in his Orientalism (New York: Pantheon Books, 1978).

7 The technique of flipping a picture of one's opponent back and forth was not new to the Bush 2004 campaign; it had been used to great effect by Nixon against McGovern in 1972. At 
Kerry had invited them to South Boston to get shots of him bowling, one doubts that he would have opened himself up to such derision.

And the visual aspect of the ad was easy to produce: showing some shots and reversing them in coordination with the music. The hardest thing was to splice the musical phrases together at the end (oo:24) in order to arrive at a convincing cadence at the wind sound effect and the voice-over stinger "John Kerry: whichever way the wind blows."

The Blue Danube (An der schönen blauen Donau, Op. 314) by Johann Strauss II is well-known to American viewing audiences, so it is an excellent choice in a medium where instant recognition is essential. Hearing familiar music, viewers can easily replay the ad in their heads repeatedly. Having seen the ad many times, some people may even begin to permanently associate images of Kerry windsurfing with this music, so that whenever they hear the waltz, in whatever context, they will think of "flip-flopping Kerry."

But it is the phrasing that makes the music so effective for this ad. Such phrasing illustrates stereophonically what is asserted rhetorically by the narrator and the written text. Characteristic of this section of the waltz is a question-and-answer format: the bassoon, violins, cellos, and horns "ask the question," ending on the dominant, and most of the rest of the orchestra "answers," ending on the tonic. Alternatively, we could interpret it as advocating a position, then immediately opposing that position: Dah dah dah dah dah (bling bling, bling bling). The questions and answers are easily interpreted (not consciously, in most cases) as Kerry saying one thing, and then contradicting himself. (Kerry famously said "I actually did vote for the 87 billion dollars, before I voted against it," apparently oblivious to how difficult it would be afterward to explain fine points of parliamentary procedure to the general public.)

The phrases, exactly symmetrical, work excellently to aurally represent diametrically opposed positions on foreign policy issues (the Iraq war, military funding) and domestic issues (education, Medicare). When the music is mixed with images of Kerry windsurfing alternately to the left and to the right, we are served a potent cocktail indeed.

"Windsurfing" is metadiscursive. It does not address issues per se-there are no specifics to bolster the assertions-rather, it is about Kerry's alleged proclivity to tergiversate. As such, this ad is about character. The ad's creators were counting on the public accepting the flip-flop assertion and also drawing the concomitant conclusion that Kerry is weak and wishy-washy

the end of the ad, the picture of McGovern just spins on its axis. The comic effect is notable, but without music, its effect was limited. 
(rather than thoughtful and circumspect, able to reassess a situation in light of new evidence, as such an outcome might suggest).

Criticized by some for a pigheaded unwillingness to reconsider his positions, even when circumstances dictated a reassessment, George W. Bush and his campaign successfully framed stubbornness and recalcitrance as steadfastness and determination. By contrast, then, Kerry was defined by the Bush campaign as mutable and unreliable- "whichever way the wind blows." The clumsy splice of cadential music toward the end of the ad was worth the brief awkwardness: a thundering, crashing cadence puts a full stop on Kerry's foolishness.

Kerry could not win for losing. Disparaged by the media, who peddle excitement, danger, and drama, for being a tedious stuffed shirt, a ponderous policy wonk with a monotone voice, Kerry ached to show people his lighthearted, easygoing side, not to mention his considerable skill at a difficult sport. Previous presidents were known for special talents and skills having nothing to do with the Presidency necessarily: Hoover spoke fluent Chinese, Carter did woodworking, Clinton played saxophone, Eisenhower painted, Truman and Nixon played piano. Hobbies humanize the President and make him seem more well-rounded. Kerry, though, hoping to gain some goodwill with voters for his extracurriculars, did not do his candidacy any favors with this unfortunate photo opportunity.

Kerry looks carefree in the ad, which could imply that he is unconcerned about Iraq, Medicare cuts, or improving education—all issues mentioned in the ad-but also terrorism, which was not mentioned (but was in plenty of others in the Bush 2004 campaign). Although carefree, he does not necessarily look presidential, and the music makes him seem unsubstantial. With so many people strongly committed to one side or the other of a sharply divided electorate, low involvement voters actually decided the election. It is disheartening to imagine that a comical ad making Kerry appear foolish could have-together with numerous other attack ads that year-tipped the scales in Bush's favor. Desperation breeds creativity. Bush was trailing in midsummer polls, but with a spate of clever and potent ads, the campaign was able to tighten the gap by autumn. "Windsurfing" is metaphorically so compelling that voters might accept the claims of flip-flopping without bothering to assess whether the claims are true, exaggerated, or merely specious.

In the next chapter we will explore how music was being used in innovative ways in political ads, including the use of music by African Americans to accompany ads for the first African American presidential candidate to receive the nomination of a major American political party. 


\section{Yes, We Can: 2008}

In 2008, petroleum for the first time ever reached $\$ 100$ per barrel. Fidel Castro resigned as President of Cuba. A large part of the Wilkins Ice Shelf in Antarctica fell off into the ocean, making the rest vulnerable. An attempt on the life of Afghan President Hamid Karzai was made by the Taliban. Dmitri Medvedev replaced Vladimir Putin as Russian President. Robert Mugabe was re-elected once again as President of Zimbabwe amid allegations of corruption. In Belgrade, Serbia, Radovan Karadžić was arrested after being on the lam for twelve years. Pirates off the Horn of Africa attacked and hijacked cargo ships from a number of countries, sparking fear of the high seas and leaving government and military officials scrambling to eliminate the problem. After the Dow Jones Industrial Average dropped by a huge 777 points, a global financial crisis began, casting a large shadow over the US presidential election.

The 2008 election was a competitive election with Barack Obama and John McCain emerging with the nominations of their parties. Although McCain secured his nomination fairly early, on March 4, the Democratic primary continued until June 7. Among the Republicans defeated by McCain were Rudy Giuliani, Mike Huckabee, Mitt Romney, Ron Paul, Duncan Hunter, Alan Keyes, and Fred Thompson. Unsuccessful Democrats were Mike Gravel, Christopher Dodd, Dennis Kucinich, Joe Biden, John Edwards, and, finally, Hillary Clinton.

George W. Bush, who had barely won re-election in 2004, was polling very badly in his second term (his average second-term approval rating was $37^{1} \%^{1}$ ), especially after the 2008 economic crisis erupted. In the week of the 2008 general election, Bush was polling at a $70 \%$ disapproval rating, with only $25 \%$ approving of his performance. ${ }^{2}$ Thus, candidates strove to distinguish themselves from the President as much as possible. Change was the watchword, with health care, unemployment, and climate change front and center. Among other salient domestic issues as the 2008 election approached were the bursting of the housing bubble, a sharply declining stock market, and a credit crisis. On the foreign policy front, wars raged on in Iraq and Afghanistan.

1 Gallup, "Presidential Approval Ratings_-George W. Bush," www.gallup.com/poll/11650o/ presidential-approval-ratings-george-bush.aspx (accessed August 1, 2016).

2 Gallup, "Presidential Approval Ratings” (accessed August 1, 2016). 
Clinton, a well-known Senator from New York in her second term and former First Lady for eight years, thought that she had the nomination sewn up early in the primary season. In fact, conventional wisdom among prominent Democrats and members of the media had it that Clinton would easily garner the nomination. But Obama's campaign was relentless, both with the public as well as with superdelegates, and eventually he overtook her to become the first African American to run in a general election for the presidency. As we will see, race was a contributing factor in some ads from this year.

Elbows were sharp during this election. Ads were created with dizzying rapidity based on video and audio clips of opponents. In some cases, ads were aired less than twenty-four hours after an opponent made a controversial comment.

\section{Yes, We Can \\ Obama-Biden \\ will.i.am and Jesse Dylan \\ 04:20}

Most original among ads of the 2008 campaign was probably "Yes, We Can." The work primarily of will.i.am of the Black Eyed Peas and Jesse Dylan, "Yes, We Can" is unique in a number of ways. It gathers together a number of celebrities to advocate for the first black president in US history. Among these celebrities are Kareem Abdul-Jabar, Common, John Legend, Tatiana Ali, Kate Walsh, Aisha Tyler, Sam Page, Johnathon Schaech, and Scarlett Johansson. The ad text consists exclusively of quotations from a speech in which Obama conceded victory in the New Hampshire primary to Hillary Clinton. Despite the speech being of a concessionary nature, it sounded more like a rousing victory speech in this rendition.

Music in "Yes, We Can" typifies the manner in which Democratic ads in the 2008 election were uncharacteristic of their earlier efforts. Making use of African-American culture, this ad harnesses popular support for the first black presidential candidate with a chance of winning. A unique historical moment gave rise to a unique ad embodying hope. Various speakers and singers mimicking the inflections of Obama's speech. The participants are relaxed and happy, self-confident in their message of hope.

A strummed guitar accompanies, the same four-chord progression in $\mathrm{G}$ major repeated throughout:

$$
\begin{aligned}
& \mathrm{I}-\mathrm{V} / \mathrm{vi}-\mathrm{vi}-\mathrm{V} \\
& \mathrm{G}-\mathrm{B}-\mathrm{Em}-\mathrm{D}
\end{aligned}
$$


Obama's rhetorical style lends itself very well to joining with singing. At his best moments, Obama's cadences make him sound something like Martin Luther King, Jr.

Throughout, singers and actors recite phrases from the speech, approximating the intonation patterns and prosody of the spoken fragments. The effect is exhilarating.

The simplicity of the homophonic guitar accompaniment has several advantages over a more elaborate musical setting. It allows the sung and declaimed text to be foregrounded and understood. Perhaps more importantly, it is an everyman's accompaniment-virtually anyone can strum four chords on a guitar. This is the music of the $99 \%$. Some people watching "Yes, We Can" might have agreed with the McCain campaign's characterization of Obama as primarily a celebrity (implying that he is a celebrity not from his accomplishments, but merely because of his personality and physical attributes) since the faces in the ad are quite well-known.

"Yes, We Can" spawned many imitations, both sincere and parody. Idealism and optimism are easy targets for ridicule by an increasingly cynical electorate and punditry. The slogan implies a question that the listener must supply, and what exactly is that question? Is it "Can we elect an African-American president?" Probably not. That is likely just a side effect. The implied question seems to be "Can we the people (today we would say the $99 \%$ ) take the power back from the moneyed elites?" Part of the reason this ad resonates so much is that this was the question that hung not only over the campaign season but has also continued to the present day. And music helped fix the message in voters' minds.

\section{Dr. No}

\section{John McCain 2008}

Foxhole Productions

00:40

Being unconstrained by federal regulations regarding propriety that govern television advertising, web ads have exhibited a great amount of creativity since their inception in presidential elections in 2004. "Dr. No" is clever and production values are high. Graphics in "Dr. No" have the feel of title sequences to early sixties James Bond films, including the Wide Latin font of the text, circle wipes, bold graphics in bright colors, and black-andwhite pictures of Obama. Black-and-white pictures of Obama are dragged comically onto screen, along with text and Obama voice-over about energy 
initiatives that he opposed or did not plan to pursue, specifically offshore drilling, a gas tax holiday, electric car innovation, and nuclear energy. It ends with the text "Barack Obama Truly Is The Dr. No of Energy Security" [sic]. Although the ad was well-produced, it is unclear which candidate it may have helped, as I discuss below.

Republicans recently have been characterized as the "Party of No" because of their blocking initiatives coming from the Obama White House or from their colleagues across the aisle. This reputation has arisen due to the stranglehold the Tea Party has had over the Republican Party. Therefore in a move that might be characterized as "the pot calling the kettle black," the McCain campaign cast Obama as Dr. No in a mini-drama of obstructionism. Casting Obama as an actor in a film comports with McCain's strategy to portray him as a callow celebrity seeking only to aggrandize himself.

Music is as close as it could be to the original Bond theme while still steering clear of copyright violation. Motives from the James Bond theme are in the same tessituras and played by the same instruments-as the original motives are merely inverted or rearranged. But the musical referent is clear, and it is the music that makes it clear.

"Dr. No" casts Obama as one of the most notorious villains of James Bond lore. By implication, McCain is himself oo7. However, a drawback to this ad is that it could easily be misinterpreted by viewers not paying close attention. With the music playing as he speaks, Obama could actually come across as suave superspy and man of mystery James Bond rather than the infamous Dr. No. Obama's general demeanor-calm, cool, collected, with a ready wit in the face of adversity - would appear to qualify him to take Bond's place. In other words, to the inattentive listener, "Dr. No" could seem like an advocacy ad for Obama.

\section{Celeb}

John McCain 2008

Producer: Foxhole Productions

oo:30

Intending to use Obama's popularity against him, McCain released an ad entitled "Celeb." As we hear a loud reverberating timpani stroke that demands our attention, we see scenes from a packed Straße des 17. Juni during Obama's July 2008 speech in Berlin. In the months leading up to the speech, McCain had been struggling mightily to wrest media attention 
from the Senator from Illinois, with whom the media seemed fascinated. ${ }^{3}$ Interposing pictures of Obama with shots of Britney Spears and Paris Hilton, the ad implies that his celebrity is due to his magnetic personality rather than any of his life achievements or personal character. Britney Spears is perceived by some as a celebrity with only mediocre talent and Paris Hilton as a celebrity merely by dint of the family she belongs to. Setting these two pop singers against a US Senator and major party nominee is an attempt to make him seem inconsequential. The incessant chanting "o-BA-ma, o-BA-ma" forms a rhythmic motive behind the ad. Audience members seem to be entranced by Obama.

Flash bulbs going off between sequences heightens the sense of starstruck awe that many Obama supporters felt (to McCain's chagrin). McCain may have felt that he, as the senior Senator and former prisoner of war, should be courted by the media. His campaign, expecting a hero's treatment, made much of his military experience and the five and a half years he spent in a North Vietnamese prison. (His previous close association with George W. Bush and especially his about face on strongly held moral beliefs such as his stance against torture of enemy combatants-which he changed in order to ingratiate himself with the hardliners in his party—-tied him too snugly to the previous administration.)

"Celeb" may have been meant to allude explicitly to the highly controversial ad run in Tennessee by Republican US Senate candidate Bob Corker against Harold Ford, Jr. Others have noted the similarity, such as Bill Press, here writing for the Huffington Post:

Of all the famous celebrities they could have compared Obama to, why not Tom Cruise? Or Arnold Schwarzenegger, or Donald Trump, or Oprah Winfrey? Why Britney Spears and Paris Hilton? Why two white blonde bimbos? Only one reason. It's a somewhat tamer version of the white bimbo ad used so successfully against Harold Ford in Tennessee. In juxtaposing Barack Obama with Britney Spears and Paris Hilton, the McCain campaign is simply trying to plant the old racist seed of black man hitting on young white woman. Not directly, but subliminally and disgracefully. ${ }^{4}$

3 McCain was able to carve out some media interest when on August 29 he announced his unconventional pick for Vice President, Alaska governor and former Wasilla mayor Sarah Palin. Soon Palin was receiving the celebrity treatment from media outlets.

4 Bill Press, “John McCain Plays the Race Card," Huffington Post, July 31, 2008.

<http://www.huffingtonpost.com/bill-press/john-mccain-plays-the-rac_b_116042.html>. Accessed December 31, 2015. 
In fact, "Celeb" was so beyond the pale that Paris Hilton actually did her own web parody version of it. ${ }^{5}$ Hilton's parody highlighted how ridiculous McCain's ad was, thus blunting the effect of the ad. So while the female narrator asserts policy positions for Obama such as higher taxes and more dependence on foreign oil, the undercurrent of racism operates on an altogether different plane.

An opening loud stroke on a kettle drum, rhythmic chanting of "o-BA-ma, o-BA-ma," an additional timpani strike at oo:18, and a brief guitar and piano riff in $\mathrm{C}$ major during the McCain disclaimer at the end constitute the musical elements of "Celeb." All of them have important semiotic function in the ad, whether to gain viewers' attention (drum strokes), to denigrate Obama as nothing more than a callow celebrity (chants of his name), or to provide the answer to viewers not wanting to vote for Obama (the musical motto over the disclaimer).

\section{Fundamentals \\ Obama for America 2008 \\ Producer: Obama Media Team \\ oo:30}

Television advertising for the 2008 general election was bound to include ads addressing the frightening financial crisis that had begun in September. Many Americans were feeling profoundly insecure and were desperate for reassurance. Lehman Brothers, a firm that provided financial services and one of the large Wall Street corporations, filed for bankruptcy on September 15. This shocked the banking sector and was just one of the unfortunate outcomes of the 2008 crash.

"Fundamentals" presents a clip in which McCain is shown asserting on the day of the Lehman Brothers crash that "the fundamentals of our economy are strong." The audio is played twice more over graphics that question McCain's grasp of the economic crisis that obtained at that time. At the end of "Fundamentals," the hollow "are strong, are strong ..." echoes into oblivion. This ad gives viewers the sense that the situation is dire and that McCain is either cynically lying or naïvely deluded about the nation's financial well-being (neither being a positive interpretation for McCain). In the context of an economic crisis that was gaining steam as the election

5 "Paris Hilton Blastin McCain," YouTube, <http://www.youtube.com/watch?v=khE6vimLoq4>. Accessed February 18, 2017. 
approached, McCain's quote likely sounded more like a well-rehearsed talking point than an accurate assessment of the state of the US economy.

The ominous $\mathrm{F} \#$ minor sonority, low F\# drone, and insistent motoric rhythm with syncopated accents on $\mathrm{F} \#, \mathrm{G} \#$, and A accompany the headlines.

Reminiscent of news program music to inject drama into reporting the news, music in "Fundamentals" is urgent, demanding our attention. As is the case with much news music, it is also repetitive, with no forward progression. Such "wheel-spinning" can be interpreted as a musical representation of McCain's being stuck in a rut, unable to emerge with bold, fresh ideas to address a dire crisis.

The music stops abruptly as a black screen appears with white text "The Fundamentals of Our Economy Are Strong?" Silence itself calls attention to the text. Dramatic news music creates space for silence to reverberate; viewers are invited to reflect on the rhetorical question. The Obama campaign's use of the McCain video showed the Republican as an automaton robotically reiterating the line about the fundamentals of the economy, ignoring evidence that indicated there was cause for worry. To many, McCain seemed disconnected from reality. The Obama campaign by contrast was on top of things: this ad ran the very day after McCain's remarks. In this case as well, Obama used his opponent's words against him. Again, dramatic "news music" conveyed the needed sense of urgency.

\section{Embrace}

\section{Obama for America 2008}

Producer: Obama Media Team

00:30

"For decades he's been Washington's biggest celebrity," begins the narrator in the ad "Embrace." A viewer having gone to the kitchen for a snack might think when hearing this, "Is this another McCain ad criticizing media infatuation with their golden boy Obama?" But the screen images tell a different story. Images are of McCain — this ad counters McCain's "Celeb" by showing that McCain was at least as much a celebrity as Obama. After establishing McCain's celebrity bona fides, the ad takes a turn, connecting this celebrity to a cozy relationship with Washington lobbyists and oil and pharmaceutical concerns.

Setting the tone for the ad is celebrity-worthy jazz music. Politicians in positive ads tend to cloak themselves in serious, inspiring themes in orchestral textures or with simple piano or guitar, depending on what effect 
they are trying to achieve. Music such as that from The Tonight Show or Late Night with David Letterman is not typically heard in political ads. This jazz serves to define McCain as unsubstantial, lacking seriousness. Add to this several sequences of McCain grinning and hamming it up with David Letterman, appearing on The View, embracing George Bush, telling jokes on Saturday Night Live, and in other situations, and the ad becomes explosive. Showing McCain cozying up to George W. Bush implied that McCain was perhaps untrustworthy. But again it is the music that does the heavy lifting of characterizing McCain as an attention-seeking, business-as-usual politician willing to compromise his principles for opportunistic reasons.

This type of music fits well with late-night shows and morning talk shows, and the music can be a signifier of fun and frivolity. Informal music for someone not to be taken too seriously. Jazz was once considered the quintessential musical outlet for individuality and self-expression. It is not necessarily primarily seen that way anymore, particularly the type of band music for talk shows or variety shows. So it is music appropriate for portraying someone as more establishment than "maverick."

Like McCain's "Celeb" or Clinton's "Maine," "Embrace" includes a sound effect of a camera shutter clicking to emphasize the attention lavished on McCain by the media. McCain is shown to be embraced by the media and in popular culture in the same way that McCain's campaign asserted Obama was. Of course, the title speaks to one of the ad's main goals: to show how tightly McCain embraced George W. Bush's policies by showing him literally embracing Bush. A disclaimer at the end showing Obama provides the "solution" to the McCain "problem."

\section{No Maverick \\ Obama for America 2008 Producer: Obama Media Team}

"No Maverick" implies that far from a lone independent non-conformist, McCain clings to Republican and Bush administration orthodoxy. "No Maverick" strikes directly at McCain's supposed strength of independence and non-nonsense straight talk. Music puts the lie to McCain's tough maverick talk. An electric guitar playing an ascending perfect fourth from $\mathrm{E}$ to $\mathrm{A}$ with plenty of reverb starts "No Maverick." This specific musical gesture is immediately coded for the viewer as spaghetti Western film music-like Ennio Morricone's score to The Good, the Bad, and the Ugly or A Fistful of Dollars. "They call themselves mavericks," says the narrator over a picture 
of McCain waving and Palin giving the thumbs up and the text "McCain campaign ad." Just as we are processing this, we hear a whip crack and see a wipe left of a black screen with the word "Whoa!" as the narrator scoffs and reads the word. After a brief break to let "Whoa!" set in, we hear a plucked electric bass in $\mathrm{G}$ natural minor, along with a periodic piano drone on $\mathrm{G}$. This music continues for the rest of the ad, and it lends a subtle negative cast to McCain as the narrator characterizes him as being in lockstep with George W. Bush.

Humor inherent in the association with spaghetti Western guitar music and whip crack addresses McCain's assertion that he is a maverick. It lends a relaxed, calm demeanor to the ad. "No Maverick" doesn't try too hard. It is music that first attacks the maverick claim by mocking it, calling viewer attention to the term's origin as pertaining to an unbranded range animal. The narrator confirms McCain's establishment status with assertions that most of McCain's campaign advisers were lobbyists, that he voted with Bush ninety percent of the time, that Sarah Palin flip-flopped on the so-called "Bridge to Nowhere," and that they lied about their political records. Sources are cited for two of the claims in "No Maverick," so not all of the claims are footnoted, so to speak. The power of the attack lies primarily in the comic appeal of music and sound effect. Music primed the pump; the voice-over fired up the ignition.

Ads with humor require more audience participation. Whereas music's effect in a terror ad or a positive advocacy ad is immediate, with humor the signification process is more complex. In "No Maverick," the Western film guitar music and the whip crack have to be understood in a trice to be codes for Western film, this signification has to be joined to the definition of a range animal that has not been branded, then to connect that to McCain's and Palin's use of the word "maverick" to describe what they consider their anti-establishment, beholden-to-nobody stance. It's a sophisticated sequence that voters are asked to perform, but it works and in fact works with incredible speed. ${ }^{6}$ All of that signification, from Western film electric guitar riff to whip crack to the word "Whoa," takes place in a mere five seconds ... and that includes the two-second "I'm Barack Obama and I approve this message" campaign disclaimer! Its sarcastic bite mocks McCain by attacking connections to lobbyists and Palin for her "bridge to nowhere."

6 Of course, non-standard readings are also possible. A particular viewer might associate the word "maverick" with the nickname of Tom Cruise's character in the film Top Gun and might be confused by the reference. 
After a particularly intense Democratic primary that saw a still relatively unknown challenger overtake and defeat the seemingly inevitable Clinton campaign, with so much money and the establishment behind it, Obama went into the general campaign against McCain battle-hardened and savvy. Some of Obama's ads made him almost seem relaxed as if he were an incumbent President. The Democrat was more effective than the Republican at using music for its ends. "Fundamentals" had urgent "dramatic news" music along with a stuttering McCain talking about strong "fundamentals" of the US economy. "Embrace" employed jazz band music to highlight McCain's celebrity status (in the process cleverly turning McCain's "Celeb" ad against him) and with Western-sounding music "No Maverick" parodied McCain's self-styled rebel status. Finally, "Yes, We Can" gave musical voice to hope that some imagined in a potential Obama presidency.

Four years later, the Obama campaign was to hone its craft to an even keener point as the incumbent took on Mitt Romney. 


\section{The $47 \%$ Solution: 2012}

In 2012, Iran was given an embargo by the European Union, whose representatives wanted to express their disapproval of Iran continuing to attempt to enrich uranium. As part of demonstrations brought on in part by the Arab Spring, the Yemeni presidency changed hands. Dmitri Medvedev and Vladimir Putin switched jobs as leaders in Russia. An auction brought $\$ 120$ million for a rendering in pastel Edward Munch made of his famous painting The Scream. In India, 620 million people were left without power due to widespread blackouts, the largest power outage in history. With a mission to discover facts about Mars's geology, climate, and environment, the Mars Science Laboratory's rover Curiosity landed on the planet. Across the globe, numerous attacks occurred at US embassies and diplomatic missions; among these was an attack at the consulate in Benghazi, Libya, which resulted in the deaths of four American citizens including the Ambassador to Libya, J. Christopher Stevens. Hurricane Sandy ravaged much of the Eastern seaboard.

If the 2012 presidential election campaign could be distilled to one number, that number would be 47. This is the percentage of Americans who, according to Romney's infamous quote, are "dependent on the government, who believe they are victims ... pay no income tax" and whom he claimed to not be concerned with because he will "never convince them that they should take personal responsibility and care for their lives." So central was this quote to the election that it was chosen by USA Today as the best quote of 2012. ${ }^{1}$ It was an unguarded moment of candor among a group of people he thought were exclusively his supporters. Unfortunately, he forgot about the help! Scott Prouty, a bartender for the catering company handling the event, secretly recorded the comments and released them to the public.

This moment saw heavy news coverage and also fed into several Obama ads. It framed the election as being between a rich patrician who doesn't care about the plight of the common citizen and a man who presented himself as a champion of the people with his slogan "Change we can believe in."

Thus the Obama campaign's focus was on Romney being an out-of-touch rich elitist and something of a stuffed suit. John McCain, the Republican nominee in 2008, appealed to some voters for his personality. He had an excellent sense of humor, came across to many as a personable fellow, and

1 John Christoffersen, “Romney's '47\%' chosen as year's best quote," USA Today, December 14, 2012, http://www.usatoday.com/story/news/nation/2012/12/og/romneys-47-percent-chosenas-years-best-quote/1756833/. Accessed December 30, 2015. 
was a war hero and prisoner of war for over five years. Romney, on the other hand, lacked McCain's personal qualities and military background and often came across as wooden and awkward. Often, Romney's attempts at humor would fall flat. The contrast with easygoing and funny Obama was striking.

In 2012 Barack Obama was a relatively popular incumbent in a race that he ultimately won handily against Mitt Romney. But with relatively high unemployment figures that had only modestly decreased since their height during the Bush years, the Obama campaign could not afford to rest on the laurels of foreign policy and domestic accomplishments such as the Affordable Care Act or finding and killing Osama bin Laden. Thus, they could not run a comfortable and relaxed positive political campaign like Nixon's 1972 "Now More Than Ever" campaign or Reagan's "Morning in America." Thus, most Obama ads broadcast on TV or deployed on the internet were negative ads against Romney, usually pointing out hypocrisies between the Republican's stated positions and his actions.

A trend in ads from the 2012 campaign was the tendency to use an opponent's words against him in video or audio clips. Romney's ad "These Hands" quoted Obama saying: "If you've been successful, you didn't get there on your own. If you've got a business, you didn't build that — somebody else made that happen" and then had an Ohio small businessman delivering a rejoinder. Another Romney ad, "Political Payoffs and Middle Class Layoffs," showed newspaper headlines asserting that Obama catered to high-rolling donors set against an audio clip of Obama during a lighthearted moment singing a snippet from Al Green's “I'm So in Love With You." Romney's lack of musicality in singing "America the Beautiful" is on display in Obama's ad "Firms," which with no other audio than Romney's singing showed headlines about the Republican candidate shipping jobs off to Mexico, China, and India while maintaining tax-sheltered personal accounts in Switzerland, Bermuda, and the Grand Caymans. And of course, most notably, in several ads the Obama campaign used the gift that kept on giving-Romney's comments about the $47 \%$ that have already become political lore.

Because technology these days allows for constant coverage of candidates - such as cell phone videos of inappropriate comments to a sympathetic audience-opportunities abound for a candidate to use an opponent's words against him or her. Keeping one's guard up every minute on the campaign trail is exceedingly difficult, and sometimes candidates let their personal truths come out when exhausted or upset or too relaxed among a sympathetic crowd. Obama's April 2008 remark about small town residents who "cling to their guns or religion" is the Democratic counterpart to Romney's $47 \%$ comment, though he was able to win election against McCain 
in spite of it. Some politicos, such as Joe Biden and Michele Bachmann, are particularly gaffe-prone, but anyone can speak too candidly in an unguarded moment. Such instances become fodder for the other side with the internet and 24-hour news cycle feeding fuel for these stories (or non-stories).

During the presidential cycle in 2012, a number of articles were published specifically on music in political advertisements, e.g., "Campaign Ad Music: It's All About Emotional Response," a radio segment on Boston NPR station WBUR; "Music in Political Ads," a blog post by Ron Rodman for Oxford University Press; and "Listen to the Music: It's What Campaign Strategists Want You To Do," a brief opinion piece I wrote for the Portland [Maine] Press Herald. ${ }^{2}$ Rodman points out, as I do in this volume, that scant scholarly attention has heretofore been paid to how music is used in political advertisements on television. ${ }^{3} \mathrm{He}$ further notes that the Washington Post uses stock terminology to identify musical characteristics 'like 'fun,' 'inspirational, 'ominous,' 'patriotic,' 'relaxing,' 'sad,' 'somber,' and 'upbeat."'4 Of course, it is not just journalists or scholars who refer to this music in such terms. Companies that sell so-called "elements" for political ads use similar verbiage to describe their wares. One such company is Audio Sparx, which uses identifiers such as "dark, sinister, brooding, ominous music." One track they sell entitled "Corporate Progress" is described as "instrumental, dramatic, energizing." (The cottage industry of political ad music companies could itself be the topic for an entire book.)

\section{CASE STUDY}

Firms

Obama for America 2012 o0:30

Candidates should really start acting as though they are aware that anything they say or do on the campaign trail could be used against them, because

2 Andrea Shea, “Campaign Ad Music: It's All About Emotional Response," www.wbur. org/2012/10/26/campaign-ad-music/ (accessed July 31, 2013); Ron Rodman, "Music in Political Ads" www.blog.oup.com/2012/11/music-in-political-ads (accessed July 31, 2013); and Paul Christiansen, "Listen to the Music: It's What Campaign Strategists Want You to Do," Portland [ME] Press Herald (October 22, 2012) http://www.pressherald.com/2012/10/22/listen-to-the-music-its-whatcampaign-strategists-want-you-to-do_2012-10-22/ (accessed July 31, 2013). (I should add that I consider the title the editor gave to my piece an unhappy one; my opinion is that campaign strategists do not want us to listen to the music in the sense of paying careful attention, but rather just hear the music and let it wash over us.)

3 Ibid.

4 Ibid. 
otherwise they are willingly providing soundtracks to their opponents' attack ads. A case in point is an Obama ad called "Firms" in which the only musical accompaniment (the only audio, in fact) is Romney singing "America the Beautiful." Using Romney's blithe singing of a patriotic song, the Obama campaign juxtaposes for ironic effect newspaper headlines that accuse Romney of what seem like unpatriotic acts: outsourcing jobs to Mexico, China, and India and dodging US taxes by maintaining personal bank accounts in Switzerland, Bermuda, and the Grand Caymans.

Here is the transcript:

Obama: I'm Barack Obama and I approve this message.

Romney (singing): Oh beautiful for spacious skies ...

[Caption: In business, Mitt Romney's firms shipped jobs to Mexico. And China. (Los Angeles Times)]

Romney: ... for amber waves of grain ... for purple mountain's majesty ...

[Caption: As Governor, Romney outsourced jobs to India. The Boston Globe 5/1/12]

Romney: ... above the fruited plain ...

[Caption: He had millions in a Swiss bank account. ABC News 1/26/12]

Romney: ... America ...

[Caption: Tax havens like Bermuda ... Vanity Fair August 2012]

Romney: ... America ...

[Caption: And the Cayman Islands. ABC News 1/18/12]

Romney: ... God shed his grace on thee ...

[Title: MITT ROMNEY'S NOT THE SOLUTION]

Romney: ... And crown thy good with bro ...

[Title continued: HE'S THE PROBLEM.]

The initial venue for the singing is shown at the beginning: Romney is shown singing at a campaign event with the text "The Villages, FL, 1/30/12" at the bottom of the screen. As the subsequent sequences of empty factories and offices appear, reverb is been added to the voice to make it seem as though Romney were singing to empty (presumably American) factories and offices. As the headlines shift from outsourcing jobs to offshore accounts, we see scenes of the Swiss flag flying above a river, then palm trees with the ocean in the background, and finally a pan left of a pristine beach with azure water. At the same moment, Romney's voice goes comically out of tune. The concluding sequence is of a black screen with the white text "Mitt Romney's not the solution, he's the problem. Approved by Barack Obama. Paid for by Obama for America." 
Once again, it is the music that really makes the ad. Romney's musicallychallenged rendition of "American the Beautiful" provides the humorous foundation for an ad purporting to ridicule Romney's hypocrisy in claiming to be patriotic while at the same time outsourcing US jobs and dodging his tax burden. Without music, the ad could still work as a silent witness to the headlines, and it might even be effective that way. But music here, sweetened by a sound engineer, clearly makes the argument in the most powerful nonverbal way. And often the most compelling appeals cannot be reduced to words because they operate in a different manner. Such appeals are beyond words. An imperfect rendition of an American patriotic song can mirror the apparent disconnect between Romney's words and his actions.

\section{Mandatory \\ Obama for America 2012 \\ o0:30}

Coal miners in G minor. "Mandatory" begins with an Obama "I approved this message" disclaimer ${ }^{5}$ where the President is surrounded by blue collar workers, some in hard hats. We see pictures of individual coal miners interspersed with a group shot of miners standing behind Romney. In asserting that the miners were required to attend the Romney photo opportunity, Obama's campaign was implying that Romney had so much trouble rounding up working class supporters that their attendance at his rally had to be compulsory. Such a characterization feeds into the large Democratic narrative that Romney is an out-of-touch point-one-percenter. Viewers usually assume that people standing behind a candidate in an ad are there because they support him or her. Obama's disclaimer shows a still of him smiling with a group of men wearing work clothes and some wearing hard hats. Though these workers surrounding Obama are not necessarily miners, they do lend him credibility with working class voters. What is implied with music and verbal arguments is stated explicitly at the end: "Mitt Romney. Not one of us."

Here is the transcript for the ad:

NARRATOR: See the coal miners in these ads? Turns out they were told that attendance at Mitt Romney's rally was quote mandatory. Their

5 This is pursuant to the "Stand by Your Ad" provision of the 2002 Bipartisan Campaign Reform Act. 
mine was closed, lost the pay they needed, all to be props in Romney's commercial.

DAVID BLOMQUIST (OVER ONSCREEN TEXT "WWVA News Radio 1170, Host David Blomquist, 8/27/12"): Employees feel they were forced to go, they had to take the day off without pay, if they took a roll call (and they had a list of who was there and who wasn't) and felt they wouldn't have a job if they did not attend.

TEXT: MITT ROMNEY. NOT ONE OF US.

Music in "Mandatory" consists of an obsessively repetitive falling ostinato $(\mathrm{D}-\mathrm{C}-\mathrm{B} b-\mathrm{A}-\mathrm{G})$ over open $\mathrm{G}-\mathrm{D}$ fifths, with high synth chord sounds toward the end. This descent from the dominant to the tonic pitch is analogous to the falling tetrachord in Bush's 2004 "Finish It" ad. "Mandatory" cleverly links the coal miners referenced in the ad to their primary geographical location (possibly West Virginia or Kentucky?) to a musical instrument closely associated with that region, the mandolin. Ever since Bill Monroe introduced the mandolin into his music in the 1940s, the instrument has been connected to bluegrass, a genre popular primarily in areas where coal mining has been a common vocation.

Music here is simple, unassuming. The mandolin's sound was sweetened in the studio, so there are some extra tones that fatten the sound as the ad progresses. These sounds, like the mandolin music itself, are also incessantly repetitive. The rhythm is constant, and the simple melody descends repeatedly from $\mathrm{D}$ down to $\mathrm{G}$ over and over. Such incessant repetition could be interpreted as the workers' situation continuing to be bleak if Romney were elected. The mandolin lends a forlorn, desolate sound that is the foundation for the ad. Viewers are guided toward a melancholy affect that will influence how they perceive the images and voice-over.

\section{Big Bird \\ Obama for America 2012 \\ o0:30}

During an October 2012 presidential debate, Romney, in answer to a question about what he would favor cutting from the national budget, said, "I'm going to stop the subsidy to PBS ... I like PBS. I love Big Bird ... but I'm not going to keep on spending money on things to borrow money from China to pay for it." Romney could scarcely have guessed how his ill-considered remark would come back to haunt him. 
Presenting pictures of Bernie Madoff, Ken Lay, and Dennis Kozlowski, primary figures in major scandals that broke during the Bush administration, and riffing on Romney's comment during the first presidential debate, Obama's ad "Big Bird" presents the Sesame Street character as the evil mastermind behind the criminal activity. "Big Bird" delivered the goods for the Obama campaign by juxtaposing pictures of felons convicted of bilking people out of millions of dollars with pictures of a beloved Sesame Street character. Many voters saw Romney's professed intention to eliminate the miniscule funding public television receives as mean-spirited and uncalled for. More effective than a sternly-worded dressing down of Romney for not having a plan to address serious problems with the economic and political system, music in this spot seethes with sardonic contempt. "Big Bird" devastates.

Supported by sound effects, rapid jump cuts, and voice-over, the music in the ad evokes a summer blockbuster trailer. D minor music in this ad sounds apocalyptic. It is loud with urgent, irregular "slams" throughout. Describing the ad with words does not do justice to its nonverbal mordant humor. One simply must see it to experience its full effect. But it is the colossal, epic music that conveys the sinister gravitas of the evil mastermind, treblevoiced denizen of Sesame Street. Music primes voters to laugh. Without it, a viewer would scarcely chuckle at the hyperbole. Mel Brooks has said about music in comedies, "You never do funny music for a comedy. The humor must come from the truth of the situation, the juxtaposition of serious music and bizarre behavior." ${ }^{6}$ The music used in "Big Bird" had to be serious in order to be humorous.

As with earlier mentioned ads, flashes and shutter click sound effects are present throughout. The narrator parodies Don LaFontaine, the legendary voice-over artist with the gravelly bass (famous for the opening phrase "In a world ..."). In the flow of television ads for summer movies, as the campaign has heating up, this spot seemed to fit right in. Trenchant humor in "Big Bird" is refreshing in a campaign mostly dominated by sniping and mean-spirited attacks. Political ads that use satire are rarely aired on television, given the possibility of the satire being misunderstood or even backfiring. But the light-hearted touch highlights serious misconduct by criminals associated with the Republican party such as Madoff, Lay, and Kozlowski. The ad suggests the Republican nominee's priorities are

6 Miguel Mera, “Is Funny Music Funny?” Journal of Popular Music Studies 14/2 (2002): 91-113 (98), citing Brooks as quoted in Maurice Yacowar, Method in Madness: The Comic Art of Mel Brooks (New York: St. Martin's Press, 1981), ix. 
misplaced - that instead of calling into question tiny subsidies to public television, Romney should publicly repudiate real criminals and insist that they be prosecuted.

\section{Political Payoffs and Middle Class Layoffs Romney 2012 oo:30}

"Political Payoffs and Middle Class Layoffs" presents Obama as a corrupt politician courting high-money donors. Using the President's own sung lyric, the ad parodies him by juxtaposing the passage with news headlines from National Public Radio, the Washington Times, and the New York Times. Immediately afterward the onscreen text "Lots of love for the donor class. What about the middle class?" is followed by a sequence of Obama grinning and shrugging as if to imply that Obama is indifferent to a financially struggling middle class.

"Political Payoffs and Middle Class Layoffs" accused Obama of the same disregard for the middle class that the Obama campaign accused Romney of. This ad starts with hollow electronic whistles of various pitches (some are harmonics of a fundamental, while other pitches are dissonant) that unsettle the listener put against the text "Right now there are twenty-three million Americans struggling for work/Unemployment is stuck at $8.2 \%$ / Americans need help." Then as the screen shifts from white text on a black background to black text on a white background these words appear: "So who is President Obama helping? His friends." At this, we hear a roar of applause and then Obama singing "I'm so in love with you", the first line of Al Green's song "Let's Stay Together." Then, as the singing continues, we see headlines alleging preferential treatment and extra access to the White House for rich and powerful donors. Then, as we hear a thundering low drumbeat, we see in white on a black screen "Lots of love for the donor class. What about the middle class?" and the black screen dissolves into a clip of Obama smiling smugly. Next, the text "The Obama Record: Political Payoffs and Middle Class Layoffs" appears, and in the final sequence we see "ObamaIsn'tWorking.com/Paid for by Romney for President, Inc."

Just as the Obama campaign did, the Romney campaign extensively used quotes as well as audio and video clips from his opponent in attack ads against him, even — again, in both cases—using the opponent's lighthearted moment of singing against him. This ad is as deft as Obama's similar ads. Music that Obama himself supplied made the ad powerful. 


\section{My Job}

\section{Obama for America 2012}

o0:30

"My Job" shows images of working Americans juxtaposed against now infamous audio of Mitt Romney at a Boca Raton fundraiser talking about the 47 percent of alleged non-taxpayers, as silverware clinks against $\$ 50,000-a-$ plate plates. Tearing a page from the Bush 2004 playbook, "My Job" uses haunting electronic choral sounds to gradually build a C minor sonority, evoking a melancholy or even mournful atmosphere. When viewers connect this mood to Romney's remarks, the takeaway seems clear: Romney does not care about working Americans.

The $\mathrm{C}$ minor chord at the end frames the ad. Scarcely can we hear these comments without thinking of the servers at the fundraiser and wonder whether they belong to Romney's 47 percent. Emotional power in "My Job" lies in getting out of the way of Romney's own statements. The music and the lack of a narrator comment highlight the impact of Romney's remarks.

Here is a transcript of the ad:

\section{[TEXT THROUGHOUT THE AD]: "47 PERCENT" OF AMERICANS} [INTERMITTENT TEXT]: Mitt Romney's Own Words, "Dependent upon government"-Mitt Romney, "Victims"—Mitt Romney, "Believe that they are entitled"-Mitt Romney, "My job is not to worry about those people"-Mitt Romney, "I'll never convince them that they should take personal responsibility"-Mitt Romney, APPROVED BY BARACK OBAMA. PAID FOR BY OBAMA FOR AMERICA

MITT ROMNEY: There are $47 \%$ of the people who will vote for the President no matter what, who are dependent upon government, who believe that, that they are victims, who believe that government has a responsibility to care for them, who believe that they are entitled to health care, to food, to housing, to you name it. And they will vote for this president no matter what. And so my job is not to worry about those people, I'll never convince them that they should take personal responsibility and care for their lives.

Against images of American men and women of various races and ages, the stark C minor sonority frames the Romney comments as tragically misguided. If isolated, Romney's remarks might be taken merely as asserting that a certain number of the electorate would never consider voting for him, which would hardly be controversial. But the music nudges the listener 
toward interpreting Romney's thoughts as him writing off nearly half of the electorate, indifferent to their needs and disregarding priorities.

In 2012, the Obama campaign continued the types of mocking attack ads that resonated with voters in 2008. Romney gave Obama a lot of material to work with, especially with his $47 \%$ comment. Each candidate used recordings of his opponent speaking or singing in order to ridicule him. Obama (and his supporters creating web ads) had more success with this approach. What 2012 Obama ads lacked in the spirit of hope and promise, they compensated for in relaxed confidence and were responsive to the moment as well as to particular segments of the electorate. The next campaign, with no incumbent running in either party, would be an altogether different election year. 


\section{8. \#DemExit: 2016}

In January 2016, the International Atomic Energy Agency announced that Iran had adequately dismantled its nuclear weapons program, allowing the United Nations to lift sanctions immediately. The World Health Organization informed the world of a serious outbreak of Zika virus. Despite treaties it had with the United Nations, North Korea launched a rocket into space; later in the year, it conducted a nuclear test. The former president of Chad, Hissène Habré, was convicted in May of crimes against humanity and sentenced to life in prison. In June, voters in a referendum in the United Kingdom chose "Brexit," exit from the European Union, surprising many British leaders. In July, Solar Impulse 2 completed the first circumnavigation of the Earth by an aircraft exclusively using solar power. Ten days after the closing ceremony of the Summer Olympic Games in Rio de Janeiro, Brazil's Senate voted to impeach president Dilma Rousseff. Entering uncharted territory in the history of human habitation of the Earth, global carbon dioxide levels reached 400 parts per million. Resolution 2334, which denounced Israeli settlements in the Palestinian territories, was adopted by the United Nations Security Council.

Political ad music did not turn out to be prominent in the 2016 general election. Neither Hillary Clinton nor Donald Trump had ads with music of particular interest. Continuing a trend that was common in the 2008 and 2012 elections, ads from the 2016 election used video and audio clips from the opponent to cast him or her in an unfavorable light. These clips were frequently accompanied by sad or mournful music, but were otherwise presented in most cases with no narrative comment (save for a zinger in onscreen text at the very end). Clinton and Trump used this technique extensively, both apparently thinking that the opponent's own words were repugnant enough to be played with no narrative comment. The simple fact is that by and large, music in 2016 was used in unimaginative ways, ham-fisted attempts on both sides to manipulate voter emotions employed pictures of earnest people looking forlorn. Many ads were negative. Rather than focus on making a strong case for election, both campaigns focused overwhelmingly on painting the other candidate as unacceptable to voters.

Prominent among Trump ads were the hard-hitting, NRA-produced "Mark Oz Geist" (attacking Clinton on her role in Benghazi with violent imagery and urgent, newscast-type music); the scolding "Deplorables" (with a female narrator addressing Clinton's "deplorables" comment and using insistent, minor mode music); the tragic "Laura" (a mother talking about 
her son, who was murdered in 2010 by an undocumented immigrant); the accusatory "Unfit" (which detailed Clinton's FBI investigation because "her emails" with "America's most sensitive secrets" "were found on 'pervert' Anthony Weiner's laptop" and used black, white, and red colors and low drones to instill fear in the voter); and the quietly effective "Predators" (which brought together Clinton's epithets "superpredators," "basement dwellers," and "basket of deplorables" to imply that Clinton has little empathy for various groups of Americans).

Notable Clinton ads included the intense contrast ad "Who We Are" (which used Trump clips contrasted with positive sequences of Clinton, along with uplifting music, even over the Trump clips); the understated "Role Models" (with ironic, upbeat music over controversial Trump audio clips and culminating with the onscreen text "Our children are watching" and video of Clinton giving a speech about character); the identity politics "Barbershop" (which showed African Americans talking at a barbershop and a beauty salon and used gradually layered bass, drum kit, shakers, bongos, and other percussion instruments in a sort of white idea of Black rhythm); the insistent "Daisy" (in which Monique Corzilius Luiz, the woman who was the girl counting petals in the 1964 Johnson "Daisy" ad, spoke against Trump with regard to nuclear war); the quiet "Mirrors" (which used sad, "disappointed" music and challenged Trump using audio clips of him speaking about women's bodies juxtaposed against shots of girls and women looking at themselves in the mirror); and the cringe-worthy country song "Stand with Hillary."

\section{Outsourcing \\ Trump \\ Rebuilding America Now \\ oo:30}

Produced by the PAC Rebuilding America Now, Trump's "Outsourcing" asserts that the Clinton Foundation made millions by advocating for job outsourcing to India. Music in the ad sounds like Bollywood film underscoring.

Visually, "Outsourcing" starts with an Indian look. Onscreen text in henna tones reads "Hillary personally made $\$ 22$ million giving speeches" in a distinctive font that looks designed to vaguely evoke the Devanagari script. This is over a decorative border reminiscent of a lotus blossom.

Aurally, the ad has a similar feel. A male with an Indian accent begins by saying, "Let me welcome Senator Hillary Rodham Clinton." Here is a transcript of the ad: 
[TEXT: HILLARY HAS PERSONALLY MADE \$22 MILLION GIVING SPEECHES]

SPEAKER: Let me welcome Senator Hillary Rodham Clinton.

[TEXT: CLOSED DOOR SPEECH/New Delhi, India/2/26/05]

CLINTON: I don't think you can effectively restrict outsourcing. There is no way to legislate against reality.

[TEXT: SHE GAVE THIS SPEECH THEN GOT \$1,000,000 FROM INDIA IN 2008 FOR THE CLINTON FOUNDATION]

So I think that, you know, the outsourcing will continue, uh...

[TEXT: HILLARY SPEECH INCOME 4/13-3/14/OTHER MOST EXCEL-

LENT SPEECHES: (various corporate entities and amounts)]

...but I don't think there's any way to, you know, to legislate against outsourcing. I think that's, you know, just a dead end.

[TEXT: OUTSOURCING JOBS FOR \$\$]

SPEAKER: That's good news for a lot of us. Please join me to give her a standing ovation.

[She's earned India's trust. SEE THE FULL VIDEO AT REBUILDINGAMERICANOW.COM]

The Indian speaker at the beginning is the same as the one at the end; his accent marks him as non-American, specifically Indian. Yet even the onscreen text, in a decorative font, seems to "speak" with an accent: "most excellent speeches."

Clinton's remarks show that she is either resigned or indifferent to the outsourcing of labor from the United States to India and other places. (Presumably Clinton was surprised to see video of her talking to a closed-door audience in 2005 as an element for an ad from 2016.) Surrounding video of her speaking with visual and aural signifiers of India positions her nonverbally as an adversary of American workers. Clinton's campaign seems to have perceived the ad as damaging to her image, because they tried to pressure television stations to cease airing it. ${ }^{1}$

Of course, it is the music that gives the ad its most distinctive Oriental flavor. A motive in a kind of proto-E minor tonality is repetitive, highly ornamented, and centering around one pitch (D\#, in this case) — all traits found in much non-Western music. Although it is difficult to distinguish individual instruments because the music volume is so low, the instruments

1 Daniel Halper, "Clinton Campaign's Move to Force Trump Super-PAC Ad Off TV," New York Post, July 27, 2016, http://nypost.com/2016/07/27/clinton-campaigns-move-to-force-trump-superpac-ad-off-tv/. Accessed February 27, 2017. 
have a bright timbre with many prominent overtones; this is characteristic of music from Southeast Asia. Music gives the ad its distinctive atmosphere.

At this point I must depart from the discussion of music and political ads altogether for reasons that will soon become apparent.

\section{\#DemExit}

In a crowded field that included George Pataki, Bobby Jindal, Carly Fiorina, Lindsey Graham, Mike Huckabee, Chris Christie, Rick Santorum, Rand Paul, Rick Perry, Scott Walker, Ben Carson, Jeb Bush, Marco Rubio, John Kasich, Ted Cruz, and Donald Trump, the 2016 Republican primary was an ugly slugfest. Conventional wisdom had it that Jeb Bush (whose campaign styled him "Jeb!" to introduce through punctuation the energy the candidate himself lacked) had the nomination in the bag. But Bush was quickly overshadowed by candidates who were more successful at appealing to America's conservative voter bloc; in addition, one must not underestimate the role that Bush fatigue played among the electorate. Once Ben Carson withdrew from the race, there were four left: Rubio, Kasich, Cruz, and Trump. In the end, despite loud opposition from the Republican establishment, Trump emerged as the victor. Republicans may not have liked the result - which reflects popular rejection of the politics of "business as usual"-but they accepted that his nomination reflected the will of the people. Many Republicans had feared Trump would be singularly vulnerable to experienced Hillary Clinton, who seemed certain to win the nomination with only nominal opposition from Bernie Sanders.

Among Democrats, though, the situation was and remains quite different. The candidate of conventional wisdom was of course Hillary Clinton, who was expected to coast to the nomination. Yet democratic socialist Bernie Sanders, running as a Democrat, had other ideas. In the process of trying to win the Democratic nomination, he changed history. Democrats who had expected to take delight in the Republicans' strife while themselves celebrating unity found themselves before long in their own bitter struggle between the establishment and progressives for the heart of the party, a struggle that rages even today. The irony is not lost on Republicans.

Not only was the outcome of the general election in November a surprise for some, even the outcome of the Democratic primary remains a subject of bitter controversy. A 99-page study by Election Justice USA entitled "Democracy Lost: A Report on the Fatally Flawed 2016 Democratic Primaries" presents in painstaking detail the case that the Democratic Primary 
was unfair. ${ }^{2}$ It offers "direct evidence for election fraud, voter suppression, and other irregularities" (including "registration tampering," "illegal voter purging," "evidence of fraudulent or erroneous voting machine tallies"), a summary of legal actions underway (in particular in Arizona, California, Illinois, New York, and Ohio), and documentation of voter suppression and election fraud by type (direct suppression of voters, tampering with registrations, illegal voter purges, voting machine inaccuracies, and DNC obstruction and collusion).

What Sanders supporters had long suspected about bias in ostensibly neutral institutions was confirmed after a document dump from the organization Wikileaks in late July. The documents included a number of damning emails showing bias for Clinton among Democratic National Committee members as well as newspaper, radio, and television journalists. A web of collusion was revealed between the Clinton campaign, the DNC, and mainstream media outlets such as CNN, MSNBC, The Washington Post, and The New York Times. Revelations from the leaked emails led to the resignation of Congresswoman Debbie Wasserman Schultz as DNC Chair - she wasn't even allowed to strike the gavel to open the convention in Philadelphia. Further fueling speculation about collusion was the fact that numerous members of the media are related to officials from the Obama administration or with connections to Clinton. Just a few examples include President of Disney-ABC Television Group Ben Sherwood, sibling of Obama administration Deputy Secretary of Energy Elizabeth Sherwood-Randall; CNN Vice President and Washington Deputy Bureau Chief Virginia Moseley, wife of Clinton fundraiser and aide Tom Nides; and CBS President David Rhodes, brother of Deputy National Security Advisor for Strategic Communications Ben Rhodes.

Some members of the media have even openly admitted their organizations' bias. In a clip available on YouTube, CNN's Chris Cuomo says, "We couldn't help [Clinton] any more than we have. She's [gotten] just a free ride so far from the media. We're the biggest ones promoting her campaign." ${ }^{{ }_{3}}$ Cuomo's candid remark may seem surprising, but it should not be: TimeWarner, Clinton's seventh largest campaign donor, owns CNN. Interestingly, editorial boards of newspapers, magazines, and television stations at

2 Election Justice USA, "Democracy Lost: A Report on the Fatally Flawed 2016 Democratic Primaries," http://www.election-justice-usa.org/Democracy_Lost_Update1_EJUSA.pdf. Accessed July 29, 2016.

3 “CNN's Chris Cuomo: Media Has Given Hillary Clinton a 'Free Ride,"” YouTube, https://www. youtube.com/watch?v=SkXkS70Co-o. Accessed August 12, 2016. 
numerous times throughout the 2016 election cycle stubbornly refused to reflect the will of their readers and viewers; for instance, Sanders decisively won the Time reader poll for Person of the Year in 2015, but the editorial board chose Angela Merkel instead.

Even Senate Minority Leader Harry Reid, a strong Clinton advocate, admitted that Sanders was harmed by the process and that DNC Chair Debbie Wasserman Schultz had to resign, as he is quoted in a July 27, 2016 piece for Huffington Post:

I know she's tried hard, but as some people probably know, I thought Bernie deserved somebody that was not critical to[ward] him. I kneweverybody knew - that this was not a fair deal. So I'm sorry she had to resign, but it was the right thing to do. She just should've done it sooner.

The article continues:

As DNC Chair, Wasserman Schultz had scheduled many of the primary debates on weekends, when viewership was likely to be lower. Without the opportunity to debate in front of large audiences, it's difficult for an insurgent candidate to gain traction against an established rival. "Bernie really had a movement out there, and it wasn't right to treat him that way," Reid said. ${ }^{4}$

It should not escape our attention that Reid was speaking of the popular movement behind Sanders's candidacy in the past tense, as if it were going to dissipate. This does not seem to be the case, however, with groups of progressive citizens continuing to organize around the country and demand real change. Of course, Reid made his comments after the delegates had already voted and declared Clinton the Democratic nominee. He expressed no such sentiments while the nomination was still under contention. Only once Clinton had secured the nomination did Reid deem it safe to acknowledge the unfairness of the process.

Fueling speculation about a theft of the Democratic Primary, exit polls strongly indicate manipulation of the vote in multiple states. ${ }^{5}$ The United

4 Ryan Grim, "Harry Reid On Bernie And The DNC: 'Everybody Knew That This Was Not A Fair Deal'," Huffington Post, July 27, 2016, http://www.huffingtonpost.com/entry/harry-reidbernie-sanders-dnc_us_5799259fe4bo2d5d5ed42db6. Accessed July 29, 2016.

5 According to mathematician Richard Charnin, who calculated using the Binomial distribution the probability $(\mathrm{P})$ that eleven out of twenty-six polls would be greater than the margin of error, "P = 1 in 76.8 BILLION" (Richard Charnin, "The Primaries: Hillary Wins the Lottery," 
States Department of State has used exit polls in the past to allege election fraud in other countries whenever and wherever there has been more than $2 \%$ deviance between a vote count and an exit poll. Exit polling is a fairly exact science, and experts, such as Edison Research, can achieve results within a $2 \%$ margin of error. Distressingly, there were discrepancies well over $2 \%$ in favor of Clinton in many states where primaries (rather than caucuses) took place. These percentage margins in favor of Clinton include the states of Alabama (6.1), Arizona (22.1), Georgia (5.5), Massachusetts (4.0), Mississippi (4.7), New York (5.9), Ohio (5.0), South Carolina (5.2), Texas (4.2), Wisconsin (6.9), and West Virginia (6.0). ${ }^{6}$ But in the majority of cases, the differences favor Clinton and in some cases, if the vote counts had matched the exit polls within $2 \%$, Sanders would have won more states and thus more pledged delegates. When Sanders supporters started using exit polls to allege election fraud in the latter portion of the primary season, television networks that had been funding exit polling quietly cancelled exit polls in remaining states including Oregon, Kentucky, California, and New Jersey.

Other aspects of the primary process leave the observer with questions. Inexplicably, Associated Press, followed quickly by other news outlets, called the primary for Clinton on a day when there was no voting and at a time when neither candidate had a majority of pledged delegates to clinch the nomination. AP claimed to have arrived at the conclusion after surveying superdelegates (who would not vote until the Democratic National Convention in late July). The timing of the announcement was suspicious: It was made on Monday, the day before the June 7 Democratic caucus in North Dakota and Democratic primaries in Montana, New Mexico, South Dakota, and New Jersey, as well as the state with by far the most electoral votes, California. To what extent this announcement might have depressed turnout among Sanders voters in these states is impossible to say.

Some of the controversy surrounding the primary and general election has to do with Clinton's past. Some voters were concerned about her treatment of classified material while Secretary of State and about the fact that charges were not brought against her when they have been brought against lower-ranking government and military personnel for

Richard Charnin's Blog, May 12, 2016, https://richardcharnin.wordpress.com/2016/05/12/theprimaries-hillary-wins-the-lottery/. Accessed August 14, 2016. Documentation of fraudulent vote counts in American elections can be found, among other places, in Charnin's book Matrix of Deceit:Forcing Pre-Election and Exit Polls to Match Fraudulent Vote Counts (CreateSpace, 2012).

6 Richard Charnin, "The Primaries: Hillary Wins the Lottery." Accessed August 14, 2016.

7 Exit polls only indicated vote count inaccuracies almost exclusively in the Democratic Primary; the Republican exit polls matched vote counts within the margin of error. 
lesser offenses. Clinton has faced harsh criticism regarding her use of a private email server while Secretary of State during Obama's first term; allegations include that she put classified information at risk for hackers from around the world.

Clinton's nomination was history-making: Never before had a presidential candidate been under investigation by the FBI. Director James Comey came short of recommending to the Department of Justice that Clinton be indicted, but he was highly critical of her handling of classified information while Secretary of State, saying that there was evidence that she and some of her subordinates were "extremely careless in their handling of very sensitive, highly classified information." (This includes material at the Top Secret and Special Access Program levels, two of the highest levels of classification). While not legally threatening to Clinton's campaign, Comey's characterization of her practices was politically harmful. Many noted that Comey's "extremely careless" is legally coterminous with the expression "grossly negligent," one of the operative terms in the statute under which Clinton was being investigated, and wondered why Comey had declined to recommend indictment based on his determination that there was no intent. Misuse of classified information does not require evidence of intent; negligence itself is sufficient to meet the standard. Some Clinton critics claim that Comey's decision not to indict indicates favoritism and that any other person who had been careless with classified information would have been prosecuted, implying that Clinton only escaped charges because she is rich and prominent.

Led by US Attorney Preet Bharara, who has prosecuted a number of prominent cases of fraud and corruption against the public interest, a probe into the Clinton Foundation was initiated. ${ }^{9}$ (Bharara has since been relieved of his position by President Trump, so it is unclear whether the investigation will be resumed.) Whether there is an additional FBI probe into a possible pay-to-play scheme that Clinton may have run while Secretary of State, offering favors and contracts to individuals and foreign governments in exchange for donations to the Clinton Foundation, Director Comey declined

8 James Comey, "FBI Director James Comey FULL STATEMENT on Hillary Clinton Email Investigation (C-SPAN)," YouTube, https://www.youtube.com/watch?v=ghph_361wao. Accessed August 18, 2016.

9 Francesca Chambers, "Is America's toughest prosecutor acting on the Clinton Foundation? Preet Bharara, scourge of corrupt NY pols, 'investigating' family charity," Daily Mail, August 12, 2016, http://www.dailymail.co.uk/news/article-3736807/Is-America-s-toughest-prosecutoracting-Clinton-Foundation-Preet-Bharara-scourge-corrupt-NY-pols-investigating-family-charity.html. Accessed August 18, 2016. 
to say while testifying before Congress on July 7, 2016. Comey was specifically asked this by Congressman Jason Chaffetz. ${ }^{10}$

Then there was the vote itself. Vote rigging is not new: Ever since there have been democratic elections, there have been attempts to subvert the majority will. But it is even more pronounced and easy to perpetrate in the era of electronic voting machines. Some of the machines in use in the United States today have been banned in Europe and elsewhere for having no paper trail and being easily hackable. Even absent a hack from an outside entity, machines can be programmed by insiders to count one candidate's vote fractionally rather than as complete votes (for instance, machines can be directed to count a vote for candidate $P$ as 1.2 votes and for candidate $Q$ as 0.8 of a vote). Voting machine software is proprietary to the manufacturer and is typically not made available to the public for examination, with companies citing patent concerns. In addition to machines counting fractional votes for one candidate, vote counts can be manipulated in other ways. ${ }^{11}$

Experts in psephology have been on the case for some time now, as fraud has been revealed in American presidential elections of the past fifteen years or so. One independent study, "An Electoral System in Crisis, ${ }^{,{ }^{2}}$ by lulu Fries'dat and Anselmo Sampietro in collaboration with Fritz Scheuren, gives context to the aforementioned Election Justice USA report "Democracy Lost" by looking at data from elections going back to 2000 . What this reveals is an extraordinary level of election fraud in the current cycle compared to earlier elections, when the fraud, while existent, was less prevalent.

Many issues remain to be resolved. Lawsuits have been filed. One such lawsuit is a class action on behalf of Sanders voters, which was filed by the Miami law firm Beck and Lee against the DNC "and any associated people or entities for taking contributions given by Sanders supporters in good faith while they were colluding to ensure Clinton's nomination. ${ }^{{ }^{13}}$ The suit was dismissed by Judge William J. Zloch in September 2017; however, the firm has filed an appeal with the $11^{\text {th }}$ Circuit Court of Appeals. ${ }^{14}$

10 James Comey, "Congressman Chaffetz asks Comey about the Clinton Foundation," YouTube, https://www.youtube.com/watch?v=-CSvtTyiTE8. Accessed August 18, 2016.

11 A thorough documentary called Holler Back: [not] Voting in an American Town demonstrates with actual machines some of the ways in which this is possible and at the same time shows that manipulation can happen without leaving a trace.

12 lulu Fries'dat, Anselmo Sampietro, and Fritz Scheuren, "An Electoral System in Crisis," July 25, 2016, http://www.electoralsystemincrisis.org. Accessed August 13, 2016.

13 Michael Sainato, "Debbie Wasserman Schultz Served Class Action Lawsuit for Rigging Primaries," Observer, http://observer.com/2016/o6/debbie-wasserman-schultz-served-classaction-lawsuit-for-rigging-primaries/, June 30, 2016. Accessed July 29, 2016.

14 The document is available at jampac.us/wp-content/uploads/2017/og/63-Notice-of-Appeal.pdf. 
Particularly dismaying is a study published in Perspectives in Politics by Martin Gilens and Benjamin I. Page entitled "Testing Theories of American Politics: Elites, Interest Groups, and Average Citizens." It indicates that rather than a democracy, the United States is effectively an oligarchy, with ordinary citizens having little to no effect on policy. ${ }^{15}$ In this context, one can forgive a citizen for feeling as though elections are preordained and that there is no reason to participate in a rigged system that installs its chosen candidates. Many Sanders supporters felt disrespected and disillusioned by a process declared faulty even by some on the winning side (as Harry Reid's comments testify). Almost immediately after Sanders publicly endorsed Clinton (though he had not yet conceded), the Twitter hashtag \#DemExit began to trend. Sanders voters who felt cheated took their frustrations out with creative memes posted there.

People saw pictures distributed through social media of huge rallies of thousands for Bernie Sanders and tiny-one might charitably say "intimate"-meetings with small numbers of Hillary Clinton supporters. People saw record-breaking donations to Sanders's campaign, which proved that the right candidate would be able to avoid having to take money from Super PACs. Those people who were paying attention saw volunteers give, in addition to their money, boundless time, energy, and hope. Then they saw election results that did not coincide with apparent reality.

The narrative presented by the Clinton campaign, the DNC, and the mainstream media was that so-called "Bernie bros" were lazy slackers, daydreaming idealists who couldn't be bothered to get to the polls (hence Clinton's primary victory in spite of her poorly attended rallies). President Obama even said during his DNC speech, after hearing people boo his mention of Republican candidate Donald Trump, "Don't boo-vote." But in light of evidence of everything from purges to suppression to vote tampering and fraudulent vote counts, many people question whether there really is an inviolable right to vote for American citizens. In other words, maybe booing is all some voters can do.

\#DemExit was created to give disillusioned Democrats who had decided to leave the party a place to share a sense of community and common purpose while at the same time expressing their displeasure at party officials in a torrent of shared articles, memes, and critical comments. The name derives from "Brexit" (the recent decision by a majority of British voters to exit the European Union—a "British exit"), which itself derives

15 Martin Gilens and Benjamin I. Page, "Testing Theories of American Politics: Elites, Interest Groups, and Average Citizens," Perspectives in Politics 12/3 (2014): 564-81. 
from "Grexit" (the European Union's threatened dismissal of Greece from the Eurozone if they did not accept certain draconian economic austerity measures imposed by the organization). In a recent book, Thomas Frank asserts that the Democratic Party has largely abandoned its traditional constituencies of labor and the disadvantaged in favor of corporations and an elite professional class. ${ }^{16}$ \#DemExit is in large measure a reaction to this fact.

Not merely a Twitter hashtag, DemExit is the name given to a mass exodus of progressives from the Democratic Party. Had those millions not left the party in anger, Hillary Clinton might have defeated Donald Trump (as had been widely predicted in the media). "Bernie or Bust" was the rallying cry of the massive protests at the Democratic National Convention in Philadelphia in July. Superdelegates advanced Clinton across the finish line to become the Democratic nominee, but without the support of many progressive voters - who sat out the election, voted for Jill Stein or another third party candidate, or even voted for Trump ${ }^{17}$ — she ultimately lost the general election.

Following the election, those same progressives started a new meme and hashtag, \#BernieWouldHaveWon, reminding Democratic elites of the polls that had showed Sanders trouncing Trump by double digits in a hypothetical general election matchup. As a result of the presidential election loss, progressives and moderates must now watch as their priorities are pushed aside by the new administration. Even worse, though, what should be priorities of any government today (such as climate change, where there is scientific consensus about the need for immediate dire action to save the planet for human habitation) will be delayed even further as a result of the election. Looking ahead to 2020, progressives have started a new organization, Draft Bernie, which has its own website, Twitter hashtag, and Facebook account. ${ }^{18}$

The premise of this book depends on a reliably democratic election process. If there is any hint of taint in the process, then what good is discussion of musical appeals to emotion intended to influence voters? Given the

16 Thomas Frank, Listen, Liberal, or What Ever Happened to the Party of the People? (New York: Metropolitan, 2016).

17 Many progressives viewed Clinton, despite her party affiliation, as the more likely candidate to support war abroad and to advocate for the economic status quo domestically, which continues to be unsustainable for America's poorest citizens. For those who believed this, Trump was the only choice, but one made reluctantly and with the knowledge that his policies would be retrograde and anti-progressive.

18 These are https://draftbernie.org/, https://twitter.com/draftbernie, and https://www. facebook.com/DraftBernieSanders, respectively. 
circumstances that currently obtain in the American election process, one must acknowledge the relatively lesser role music can play as an agent of persuasion when the actual means of voting itself are in question. After all, of what importance are political ads if large portions of the electorate are prevented from expressing their will? Regarding election integrity, Tracy Campbell writes:

To reclaim the ballot box, we must start with the humblest of beginnings, the awareness that there really is a problem, and confront the uncomfortable truth that election fraud has been a common component of our nation's electoral history, and, in the aggregate, undermines the only check that the people have over their leaders. This fundamental threat to our democratic birthright must no longer be dismissed by partisan finger-pointing or trivialized by technological updates. The stakes are too high. ${ }^{19}$

Nevertheless, I should discuss the most powerful ad of the 2016 election season, a primary ad that first ran in January of that year. If any political ad music made a strong impression on voters in 2016, it was the music of this ad.

\section{CASE STUDY \\ America $^{20}$ \\ Sanders - Bernie 2016 \\ 01:00}

Bernie Sanders launched his unlikely presidential campaign from his hometown of Burlington, Vermont. Refusing to accept Super PAC campaign contributions, Sanders relied on online contributions of supporters giving an average of \$27 per donation. An April 25-May 4, 2015, Quinnipiac University poll of likely Democratic Iowa caucus voters had Sanders at $15 \%$ with Clinton at $60 \%$, which the pollsters called an "early lock" for Clinton. ${ }^{21}$

19 Tracy Campbell Deliver the Vote: A History of Election Fraud, an American Political Tradition, $1742-2004$ (New York: Carroll and Graf, 2005), 340.

20 Discussion here derives from my article "Musical Yearning in Bernie Sanders's Ad 'America," Trax on the Trail, February 2, 2016, http://www.traxonthetrail.com/article/musical-yearningbernie-sanders's-presidential-primary-ad-“america”. Accessed August 18, 2016.

21 "What Trouble? Clinton Has Early Lock On Iowa Caucus, Quinnipiac University Poll Finds; Sanders, Biden Are Only Dems Over 3\%," May 7, 2015 https://www.qu.edu/news-and-events/ quinnipiac-university-poll/iowa/release-detail?ReleaseID=2224. Accessed August 13, 2016. 
The February 2016 Iowa caucus results, however, showed an effective tie between the two- $49.9 \%$ for Clinton and $49.6 \%$ for Sanders.

Harnessing progressives' yearning for a more equitable and compassionate society as he does with his political ad "America," Sanders gave the Clinton campaign fits throughout the Democratic Primary. Republican strategists seemed torn between welcoming Sanders as a too-idealistic candidate who could be easily beaten and fearing that he was riding a juggernaut of social change that would not be stopped.

A striking internet ad for the Sanders campaign seems to inspire many voters. $^{22}$ It was among the most shared political ads on social media and garnered millions of YouTube views in its first week. It presents images of rural and small town America-spinning wind turbines, Main Street, tugboats docked along the riverbank, farmers feeding livestock, as well as scenes from a coffee shop and family scenes that could be anywhere. These are interspersed with sequences of Sanders on the campaign trail talking with individual voters and speaking to large crowds. The ad has a specific locale: Iowa. This is not surprising given how closely Iowa is associated with agricultural imagery; "America" situates itself in middle America, "God's country," "heartland America." Sanders appears comfortable in this milieu, smiling and welcoming supporters.

Together with sound effects of crowd roars at irregular intervals, "America" uses as its soundtrack the beginning and ending of the eponymous song by the folk rock duo Simon and Garfunkel. From the 1968 album Bookends, the song was originally written four years earlier while Paul Simon was hitchhiking across the US with his then-girlfriend Kathy Chitty. In Paul Simon: A Life, Marc Eliot writes that the song "creates a cinematic vista that tells of the singer's search for a literal and physical America that seems to have disappeared, along with the country's beauty and ideals." ${ }^{23}$ If that was true for people in 1968, it is just as true today for voters who feel that the America that they learned about in school does not exist.

Like "Nixon Now," a prominent 1972 TV spot of a self-confident incumbent, "America" makes no claims of grandiose accomplishments_-there is

22 Another prominent Sanders ad in this campaign was "Revolution," whose soundtrack is "It's a Revolution" by Diplo. The musician, producer, DJ, and Sanders supporter endorsed Sanders in February on Twitter (appropriately enough, given social media's huge influence these days on current events, including political campaigns). Intended to appeal primarily to a younger musical demographic than the Simon and Garfunkel tune, the ad nevertheless shows images of people of all ages canvassing for Sanders, attending rallies, posting signs, calling voters, painting posters, and so on. This is one of several notable ads for the Sanders campaign.

23 Marc Eliot, Paul Simon: A Life (Hoboken, NJ: Wiley, 2010), 95. 
nothing to fact check. Instead this is an atmospheric ad intended to capture the idealistic spirit currently animating his volunteers. Unlike the 2008 McCain campaign's unauthorized use of "Johnny B. Goode" at campaign appearances, a use to which Chuck Berry strenuously objected, as have other artists whose songs have been appropriated for political campaigns, Sanders's campaign was given permission by both artists to use the song with their good wishes. ${ }^{24}$

Commentators, such as Susan Page of USA Today, have compared Sanders's “America" to Reagan's "Morning in America." ${ }^{25}$ They see both as creating a euphoric mood, appealing through pathos and ethos, and eschewing attacks on opponents. There are clear parallels between the two ads. ${ }^{26}$ Nevertheless, the Sanders ad similarly stirs emotions. It does so cumulatively: with Sanders greeting gradually increasing crowds, the ad ends with stadiums filled with adoring fans. "America" does not need to explain Sanders's ideology or policies-it just revels in the candidate's growing popularity.

While the ad visually constructs an Iowan utopia, the original message of the song runs counter to this vision; in other words, Sanders intentionally misreads a song that is about disillusionment and unease, rather than unfettered optimism. The visual images the candidate puts forth here, combined with the omission of some of the song's less cheerful lyrics, keeps the focus on Sanders's overarching message. Simon and Garfunkel's "America" is in effect the soundtrack for the unvarnished optimism of his supporters. Hope and change deferred by ultra-pragmatic policies of the Obama administration are sought by supporters of Sanders, who is perceived by progressives as either quasi-messianic in the best case or quixotic in the worst case.

The lyric "Let us be lovers, we'll marry our fortunes together" originally refers of course to Simon and his girlfriend. As a political ad song, "Let us be lovers" speaks to another love: philia or agape, love for our fellow man. "Marry our fortunes together" conveys the sense that we must care for others and we must forge our collective future together. The lyric "They've

24 Art Garfunkel, “Art Garfunkel on Sanders Ad Using 'America,'” Interview with Michael Smerconish on CNN, January 23, 2016, http:/www.cnn.com/videos/tv/2016/o1/23/exp-garfunkelon-sanders-ad-using-america.cnn. Accessed August 18, 2016.

25 Susan Page, "Friday News Roundup - Domestic," The Diane Rehm Show, [Susan Page filling in for Rehm], January 22, 2016, http://thedianerehmshow.org/shows/2016-01-22/friday-newsroundup-domestic. Accessed August 18, 2016.

26 Paul Christiansen, “It's Morning Again in America': How the Tuesday Team Revolutionized the Use of Music in Political Ads," Music and Politics 10/1 (Winter 2016), http://quod.lib.umich. edu/m/mp/9460447.0010.105?view=text;rgn=main. Accessed August 18, 2016. 
all come to look for America" seems to suggest that poor and working-class Americans are searching for the ideal of America that has been eclipsed by corporate greed and political (i.e., Washington) cronyism. The appeal is thus primarily to class, although some prominent minority faces appear through the mostly white crowds.

At 00:37 into the sixty-second ad-which is incidentally the golden mean - we see a huge crowd with Sanders at the podium in front of a body of water and with a prominent American flag in the background just as the word AMERICA is superimposed over the scene, coinciding with the same song lyric. After the arrival on AMERICA, there is a dénouement that leads to Sanders's disclaimer. Not quite as slickly produced as "Morning in America," "America" is nevertheless well-conceived and brilliantly executed. I suspect Sanders will be remembered in association with this spot.

A folk-style song connotes a communal musical experience in which the audience feels connected to the performer in the struggle for a more inclusive and fairer society. The 6/8 meter lends the carefree melody a gentle lilt, while the falling diatonic bass line propels the song forward. The acoustic guitar and drum kit and the humming and close harmonies musically convey unpretentiousness and calm contentedness. Voices harmonizing together can also be interpreted as a musical representation of people working together for common cause.

On the other hand, could the use of the acoustic guitar and voice itself be a symbol of violent social upheaval? Guitars were ever-present during anti-war and civil rights demonstrations in the 196os. Most of the artists we think of in relation to social justice, the environmental cause, women's rights, and a host of other social movements played guitar and sang, such as Joan Baez, Bob Dylan, Joni Mitchell, Pete Seeger, Phil Ochs, and Sam Cooke. And the message on Woody Guthrie's guitar was, after all, "This machine kills fascists." But as Brian Barone reminds us, "[W]hile it is clear that the acoustic guitar stands in opposition to the modern, industrial, technological cast of the electric guitar, it is less clear what the political implications of that opposition might be. Such an opposition might proceed equally well on conservative grounds of traditionalism, ruralism, and individualism as it would on progressive grounds of anti-corporatism, communitarianism, and cosmopolitanism. ${ }^{27}$

27 Brian Barone, “I've Been Everywhere': Martin O’Malley and the Many Meanings of the Guitar," Trax on the Trail, January 7, 2016, http://www.traxonthetrail.com/article/“i've-beeneverywhere"-martin-o'malley-and-many-meanings-guitar. Accessed August 18, 2016. 
The visual sphere supports the aural. More specifically, editing matches the music. Cuts are rhythmically synchronized with the emphasized lyrics. Thus the editing contributes to the overall musicality of the ad. Further, some of the images might have broader implications. The spinning wind turbines could imply interest in pursuing energy independence and environmental consciousness. The word "Marry" is heard at the same time as we see two young women who could be friends or sisters but also could be partners who are now in 2016 legally allowed to marry. The message would be that the campaign is welcoming to LGBTQ people. Later in the ad we see blinking patchworks of small-amount donors. This illustrates Sanders's commitment to accepting small donations from average citizens. Voters with these values will find resonance in the song's lyrics.

Because the verses are too specific and unrelated to Sanders's message (e.g., a suspected spy in gabardine with a "bowtie camera"), most of the verses and the bridge are not heard in the ad. In fact, it only uses the first two lines of the first verse and then jumps to the middle of the final stanza on "Counting the cars on the New Jersey Turnpike," with "They've all come to look for America” repeating until the end. The splice is done so well that it is virtually unnoticeable. Only those listening closely to the lyrics would hear the inconsistency.

Although the images are of Iowa and the song's lyrics are about America writ large, the singers themselves conjure up for many listeners New York City. Both Simon and Garfunkel are firmly rooted in the city, living and working there throughout their music, producing, and acting careers. So in addition to appealing to several generations of voters, from Sanders's own cohort through Generations X and Y to Millennials, the music also has wide geographical appeal. Place matters. Indeed, some baby boomers might remember the duo's participation in a fundraising concert for Democratic presidential candidate George McGovern at Madison Square Garden during the 1972 election.

Furthermore, nostalgia plays a huge role in how "America" is heard by viewers across the country. The song was among those performed at the legendary free Concert in Central Park, which took place on September 19, 1982. This concert was attended by an estimated 500,000 people, and could mark a nostalgic moment for a generation that came to age in the early 1980 s. So music in this ad could arouse nostalgic feelings in boomers as well as members of Generation X, in those who attended the original concert as well as those who subsequently bought the live album. Notable cover versions by later artists such as Yes, David Bowie, and Josh Groban would help to bridge the nostalgia gap. Tapping into a different nostalgic vein, Donald J. Trump talks about "making America great again." His slogan's implicit premise is that the country is not great as it once was. Sanders holds the same premise, and that 
is why we hear "They all came to look for America." The difference lies in the radically divergent visions of a utopian America and the means to get there.

Ever since the Bipartisan Campaign Reform Act of 2002, candidates have had to include in campaign-sponsored ads a message of the candidate self-identifying and saying that he or she approves of the ad (this is referred to as the "Stand By Your Ad" provision). Campaigns can choose to put the disclaimer either at the beginning or the end, and the choice is sometimes made strategically. That is the case here. Sanders's voice can at times come across as a bit unpolished, so instead he speaks at the end along with a smiling picture of himself at a podium with sleeves rolled up, as if ready to go to work. Excitement carries through his somewhat bland pronouncement. The disclaimer's placement at the end serves to offer Sanders as the ideal guide to help them "look for America."

Playing to voters' fears is unfortunately often devastatingly effective. But appealing to their hopes can be a winning strategy and is so rare these days that it attracts attention. So well-known has the ad become that it has been written about in The New York Times, more than once, and Stephen Colbert taped a segment in which he "assigned" various Simon and Garfunkel tunes to specific Democratic and Republican candidates. The only reason a political ad gains so much attention is that it strikes a sympathetic chord with voters who want the real world to bend toward their own vision of an ideal world. With wealth inequality in the United States at alarming levels - the top $0.1 \%$ of our richest citizens having a net worth equal to the bottom 90\% - many people desperately seek political leaders who are willing to respond to this most pressing of domestic issues. This yearning is what is portrayed musically with Simon and Garfunkel's "America."

"America" and "It's a Revolution" (with Diplo's "Revolution" as a soundtrack) were the most notable ads of the 2016 election from a musical point of view.

I did not expect to write Chapter 18 with this particular focus when I first started work on the chapter, well before 2016. Due to present circumstances, however, there seemed no benefit in ignoring current political realities in order to make my thesis stronger. For the time being, music seems to be somewhat overshadowed by other issues in the political context. In any case, the Conclusion that follows assumes the 2016 election to be an anomaly (in a number of respects) and that political ad music will continue to be used prominently in elections with the intention of shaping public opinion. 


\section{Conclusion}

Although fictional, a 1997 Barry Levinson film illuminates a number of aspects of actual political advertising, even how central music can be. Wag the Dog, which espouses the cynical view that the public is easily manipulated by patriotic symbolism, begins, following opening credits and an epigram about why a dog wags its tail (spoiler: because he is smarter than the tail), with an ad for the incumbent US president where two jockeys agree on the proposition "Don't change horses in midstream." Starting the film with a political ad shown on the poor graphics of TV set with 525 scan lines of resolution is an engaging way to start a political film. What we come to understand over the course of the film is that the ad is representative of the stale, hackneyed campaign for an embattled president with poor polling numbers. With this weak tea, the incumbent is sure to lose the upcoming election. ${ }^{1}$

Conrad Brean, played by Robert De Niro, is a political "fixer" who is hired by the president's staff and is called to the White House for damage control. He is told that a Firefly Girl (presumably the fictional version of a Brownie) has accused the president of sexual assault and that the Washington Post is going to break the story the next day. ${ }^{2}$ Then they show a rough cut of the challenger John Neal's ad that is supposed to air the day after the story breaks. After the narrator states over a dramatic timpani roll, "In the final days of the campaign, has the President changed his tune?" we see pictures of the White House accompanied by Maurice Chevalier singing "Thank Heaven for Little Girls." The narrator continues over the song, "The Presidency is about honor ... it's about principles ... and it's about integrity. This tune has got to change. On Election Day, vote Neal for President." Ending with a picture of the challenger waving to a crowd, we hear another timpani roll. The ad devastates.

1 At about 53:30, Stanley Motss, in the strategy room with Brean and White House staffers, sees one of the series of "horses in midstream" ads and opines, "Will you look at that ... shit!" adding shortly thereafter, "And the music ... where did they get that?" So the Hollywood producer charged with orchestrating the campaign recovery does not fail to notice the music in an ad that he did not produce and to form a negative opinion about its effectiveness.

2 This film was released less than a month before the revelation about the Monica Lewinsky affair. Although Clinton's indiscretion did not involve an underage girl and both Clinton and Lewinsky were consenting, political commentators at the time did not fail to note the film's prescience about sexual scandal at the White House and executive attempts to distract attention from it. 
Although neither explicitly stated in the film nor discussed by the characters, it is clearly music that delivers the punch in the ad. If the ad had a narrator stating the allegation, then the president could counter with his own interpretation of the facts. But the song makes the incumbent sound like a child molester who abused his position of authority without stating the accusation outright.

Brean realizes that he needs to change the lead story by making up and leaking absurd stories about a B-3 bomber and tensions with-of all places-Albania, chosen for its obscurity in the American public consciousness. So he heads to Hollywood to engage the services of Stanley Motss (played by Dustin Hoffman), a producer who will oversee the production of a fake war against Albania.

Music becomes important later on in the film, when a song is composed by country singer Johnny Dean (Willie Nelson) and retroactively entered into the Library of Congress in order to give the music a history. A theme song about guarding American borders and the American dream is later composed and recorded à la "We Are Family" with a number of celebrity singers and instrumentalists. The song, passed off as a song from the 1930s, becomes a patriotic rallying cry to gin up support for the war. It works like a charm.

The film ends with Motss demanding credit for producing the invented war. Brean tries to tell him that he can receive any reward he fancies - an ambassadorship, whatever - but that he can never reveal what he did to the public. When Brean senses that Motss will do so despite the warning, he has him murdered in order to assure his silence. This last scene of the movie points to the "Pay no attention to that man behind the curtain" aspect of politics. Everyone knows that politics requires media production, handlers, spin doctors, and so on, but few are aware of the extent to which reality is shaped for the public by these portrayals. The film's conclusion illustrates how dangerous it would be for those in power if the public really understood what was going on.

\section{How?}

James Deaville writes provocatively about how a new form of television news music that served to get viewers to buy into war first in 1991 during the Gulf War in Iraq and later in the post-9/11 wars in Afghanistan and (especially) Iraq again: "Production companies of today fully subscribe to music as bearer of messages, and if there is any question, we can just look to their own, often disturbing rhetoric. Thus the British firm Mokal Music advertises its broadcast 
package called Shuffle with the words 'mean and pushy, strong and persuasive. These themes cover a lot of beefy styles, all up-tempo and up attitude."”3

Deaville cites an interview with National Public Radio composer Jeffrey Freymann-Weyr about his thought process in writing music for the station that countered the militaristic musical mainstream of most media during the Iraq War: "[T] he challenge was that it needed to be serious but not gloomy, not overly militaristic or flag-waving [...] One thing I tried to do with the harmony was to introduce the ambiguity that (I hoped) would keep it from going too far in either direction - overly traditionally patriotic or overly morose. Even though the piece is centered around the key of C, I purposely avoided the one note that would make it either major or minor-all of the $\mathrm{C}$ chords, instead of $\mathrm{E}$ or $\mathrm{E} b$, have a D and F natural instead [...] Although trumpet, timpani and military snare drums are a bit of a cliché, it didn't feel right not to use them, given the history of music in times of war." This interview says a lot about how composers view writing music to accompany reporting about a war. Freymann-Weyr is clearly struggling with his misgivings about the war and how they conflict with how he thinks such music "ought to go."

In a mini-documentary posted on YouTube, Les Binet, Head of Effectiveness at communications company Adam \& Eve DDB, makes this point as he talks about a study conducted by his firm, Goldsmiths University, and Sensum (who style themselves "the emotions company") on how emotional appeals are used in advertising to persuade consumers. " "Some of the research we have done so far suggests that having really good music on an ad can increase the effectiveness [by] as much as up to twenty to thirty percent. Music can do things to people emotionally without having to actually involve any kind of rational messaging. Hollywood has known this for a very long time." We learn that the research measured galvanic skin response and heart rate of participants in response to television ads. (Galvanic skin response consists of measured changes in electrical skin resistance caused by emotional or psychological stress, which is what polygraphs were designed to detect.)

In the same clip, Daniel Müllensiefen, Reader in Psychology at Goldsmiths University and Scientist in Residence at the advertising agency DDB UK, discusses the scientific bases of the research in the field of "neuromarketing," saying, "Advertising research has been dominated by explicit testing by

3 James Deaville, "Selling War: Television News Music and the Shaping of American Public Opinion," ECHO:A Music-centered Journal 8, no. 1 (Fall 2006). Accessed July 15, 2013. http://www. echo.ucla.edu/Volume8-Issue1/roundtable/deaville.html.

4 Les Binet, "Sensum-Goldsmiths Study on the Effectiveness of Music in Advertising," https://www.youtube.com/watch?v=TzZsUMdBQQQ, March 7, 2014. Accessed July 9, 2016. 
questionnaires and surveys. The problem with these is that people [do] not always say what they think and they don't always think what they feel. And where neuromarketing is getting into is this idea that people feel something and feeling somatic responses will influence their purchasing behavior and their perception of brands ultimately. [...] [W] e want to measure [people's] response from their autonomic nervous system. We want to get 'under their skin,' literally speaking, to see what they feel, to measure what they feel, to assess the emotions they might not even be conscious of themselves."

Tony Schwartz, creator of the 1964 Johnson "Daisy" ad, had something to say to the public about how ads are conceived by their creators to manipulate people. In his book The Responsive Chord, he notes, as I have above, that visual and aural media are often able to escape deep analysis because they operate on a different place from print media: 'The problem is that no 'grammar' for electronic media effects has been devised. Electronic media have been viewed merely as extensions of print, and therefore subject to the same grammar and values as print communication. [...] A whole new set of questions must be asked, and a new theory of communication must be formulated." ${ }^{\prime 6}$

Since Schwartz wrote these words in 1973, significantly more scholarly attention has been devoted to the visual aspects of commercials and political ads, but with regard to the affective nature of the auditory element, Schwartz's words still ring true. (In addition, rhetorical message analysis remains a key focus of much work on political ads, and as we have noted, most of the power of ads lies in the nonverbal.) It may seem odd that the aural has received less attention up to now, as Schwartz himself asserts "[I]t is more accurate to say that television is an auditory based medium."7 The second edition of The Responsive Chord bears the subtitle "How media manipulate you: what you buy ... who you vote for ... and how you think." This subtitle makes explicit what the book is about, and it illuminates the meaning of the title itself. Chord comes from the Greek word for string. It seems to imply the possibility of advertisers "playing viewers like a harp."

One might wonder how relevant television ads are in the age of the internet. Inside Campaigns: Elections through the Eyes of Political Professionals, written by William J. Feltus, Kenneth M. Goldstein, and Matthew Dallek, has a chapter called “Marketing Maven: Reaching the Campaign's Target

5 Daniel Müllensiefen, "Sensum — Goldsmiths Study on the Effectiveness of Music in Advertising," https://www.youtube.com/watch?v=TzZsUMdBQQQ, March 7, 2014. Accessed July 9, 2016.

6 Tony Schwartz, The Responsive Chord:How Media Manipulate You-What You Buy, Who You Vote For, and How You Think, orig. pub. in 1973 (Coral Gables, FL: Mango, 2017), 18-19.

7 Schwartz, The Responsive Chord, 14. 
Voter Audiences" - a section of this chapter bears the title "In the Internet Age, Television is Still King." ${ }^{8}$ The authors note that even though people most often watch cable, local TV stations receive the most ad buys. ${ }^{9}$ They conclude the chapter section with a quote from Sally Bradshaw, Jeb Bush's campaign manager for his successful 1998 run: "Campaigns are about more than just television advertising. But in Florida, where there are ten media markets and millions of registered voters, unless you have a viable television advertising campaign in place, all of the other things you do in a campaign won't matter."10

\section{Why?}

Ultimately, I wrote this book not out of admiration for the ability of political machines to manipulate people into voting against their best intereststhough one cannot but be amazed at the occasional subtlety and nuance of some such appeals - but rather because I see the use of music in political advertisements as a corrosive force on democracy. It is not that I dislike music - quite the contrary. Indeed, it is exactly because I value music that I despair to see it debased in the service of crass political interests.

The advertising industry is deeply invested in determining the most effective emotional appeals, even to the point of using software that can capture microexpressions of emotion (so brief that the subjects would not even be aware of them) in reaction to a particular ad, as communication scholar Cynthia B. Meyers has pointed out:

Affdex, a facial recognition software made by Affectiva, is being used by advertisers to measure audiences' emotional reactions to ads. Capturing minute facial changes, Affdex tracks viewers' fleeting emotional reactions, allowing analysts to identify through proprietary algorithms based on " 283 facial frames," their positive and negative responses to an ad. Affectiva hopes to sell this technology to the TV industry so that "smart" TVs could, on the basis of one's previous emotional responses to programs, auto-program one's TV set. ${ }^{11}$

8 William J. Feltus, Kenneth M. Goldstein, and Matthew Dallek, Inside Campaigns: Elections through the Eyes of Political Professionals (Thousand Oaks, CA: CQ Press, 2017).

9 Feltus et al., Inside Campaigns, 118.

10 Sally Bradshaw, as quoted in Feltus et al., Inside Campaigns, 119.

11 Cynthia B. Meyers, "Measuring Audience Emotions, Past and Present," A Word from Our Sponsor (blog), https://awordfromoursponsor.wordpress.com/author/cynthiameyers, April 28, 2013. Accessed August 20, 2016. 
The relationship between politics and emotion is still largely terra incognita. In an essay entitled "Cognitive Neuroscience and Politics: Next Steps," political scientist Rose McDermott writes about the urgency of investigating this connection:

[W]e are clearly at the very beginning of our understanding of the complex relations among the brain, behavior, and emotion. Humility is an appropriate emotion in the face of this realization. Recognition of such a daunting challenge should not distract us, however, from our goal of seeking greater understanding of the myriad ways in which emotion can influence political thought and action. Using more sophisticated and multiple measures in the service of more specific theories can help advance our knowledge in important ways. ${ }^{12}$

It is not as though the practice of marketing candidates like consumer goods were a secret. Vance Packard had already remarked on this trend in his 1957 book The Hidden Persuaders:

[Symbol manipulators] did not turn their attention to politics until the nineteen-fifties. Then in a few short years, climaxing in the Presidential campaign of 1956, they made spectacular strides in changing the traditional characteristics of American political life [...] by drawing upon the insights of Pavlov and his conditioned reflexes, Freud and his father images, Riesman and his concept of modern American voters as spectator-consumers of politics, and Batten, Barton, Dunstine and Osborn and their mass merchandising lore..$^{13}$

Of course, Packard was only able to evaluate elections up to 1956 because his book was published just a year later. How tame 1956 now seems through twenty-first-century binoculars!

For both of his presidential campaigns, Eisenhower used professional propagandists, in contrast to Adlai Stevenson's campaign. ${ }^{14}$ The Eisenhower campaign was represented by a New York advertising agency firm, Batten, Barton, Dunstine and Osborn. It is not as though this was a secret cabal,

12 Rose McDermott, "Cognitive Neuroscience and Politics," in W. Russell Neuman, George E. Marcus, Ann N. Crigler, and Michael MacKuen, eds. The Affect Effect: Dynamics of Emotion in Political Thinking and Behavior (Chicago: University of Chicago Press, 2007), 397.

13 Vance Packard, The Hidden Persuaders, orig. pub. 1957 (New York: Pocket Books, 1958), 155-56.

14 Packard, The Hidden Persuaders, 156. 
however - the manipulators were proudly crowing about the changes they were bringing about:

Both parties will merchandise their candidates and issues by the same methods that business has developed to sell goods [...]. Radio spot announcements and ads will repeat phrases with a planned intensity. Billboards will push slogans of proven power [...]. Candidates need, in addition to rich voice and good diction, to be able to look "sincerely" at the TV camera..${ }^{15}$

Given how naïve early political ads seem to us, we might easily forget how prevalent such cynicism has long been in the advertising world. In the above quote, "sincerely" is set in quotation marks, as if the author wanted to emphasize that the appearance of sincerity were more important than actually being sincere. It was fine for advertising executives to boast about their techniques of manipulation amongst themselves, but they were wary of their methods becoming known to the public at large. Packard quotes Advertising Age: "What is not good, it added, 'is the growing public discussion of the importance of advertising in politics." ${ }^{\prime \prime 6}$ They needn't have worried. Awareness among the public of actual techniques remains low while self-proclaimed immunity from advertising of any kind remains high.

Those writing about political ads from a social science perspective (political scientists, communications scholars, and the like) tend to downplay the effectiveness of ads, particularly with regard to music:

Perhaps of all of the concerns about political advertising, the production techniques used by candidates to sell themselves to voters are of most concern. In particular, much of the criticism of image ads has focused on their use of all types of "sneaky" editing and special effects to completely overwhelm the gullible voter. Certainly we know that voters are not as gullible as they sometimes have been portrayed, but do image ads in fact use more special effects and sophisticated production techniques to define the candidate's image? Although there are differences in image and issue ads in the use of production techniques, image ads are not dominated by special effects. ${ }^{17}$

15 Nation's Business, quoted in Packard, The Hidden Persuaders, 16o-61.

16 Packard, The Hidden Persuaders, 170.

17 Anne Johnston and Lynda Lee Kaid, "Image Ads and Issue Ads in U.S. Presidential Advertising: Using Videostyle to Explore Stylistic Differences in Televised Political Ads From 1952 to 
Using a straw man argument, Anne Johnston and Lynda Lee Kaid set up critics of image advertising by overstating their argument to make it sound unreasonable: "sneaky' editing and special effects" and "to completely overwhelm the gullible voter." The use of the word "gullible" here is meant to defang critics by dispensing with any nuance in their arguments; readers, it is implied, will either agree with Johnston and Kaid or else see voters as "completely overwhelmed" and "gullible." Johnston and Kaid's conspiratorial "Certainly we know that voters are not as gullible as they sometimes have been portrayed" invites the reader to join their club, which asserts the public's savvy about political advertising's techniques.

I think there is ample space for a middle ground. Most viewers, as I state throughout this book, lack serious training in music to able to deconstruct musical appeals aimed at them. In this regard, voters are indeed, if not gullible per se, then at least unequipped to understand emotional manipulation with the music. Moreover, regrettably, Johnston and Kaid neglect to specify what they mean by "special effects." Is music a special effect? The thrust of their argument seems to imply that they would think so, although all of the special effects they list in their Table 5 are image effects (slow motion, freeze frame, superimpositions, and the like) ${ }^{18}$ and their Table 3, listing nonverbal elements in ads, does not mention music at all, only "sound."

As we have seen, in US presidential campaigns over the course of 64 years, music has been used in many political ads. Campaigns would not spend huge amounts of money on such ads containing music without a strong conviction that music can make powerful nonverbal appeals, whether positive ones for a candidate or negative ones for the opponent. While much still remains unknown about how complex artifacts such as political ads are processed by the brain, political operatives in the present day are convinced that music is an essential component in a televised political ad. For the 2016 election, President Trump's campaign spent $\$ 600$ million, and Secretary Clinton's spent an even more staggering $\$ 1.2$ billion. ${ }^{20}$ Much of this money went toward ad buys for TV ads.

2000," Journal of Communication 52, no. 2 (2002): 281-30o (291).

18 Johnston and Kaid, "Image Ads and Issue Ads in U.S. Presidential Advertising," 292.

19 Johnston and Kaid, "Image Ads and Issue Ads in U.S. Presidential Advertising," 290.

20 Bob Fredericks, "Hillary Clinton's Losing Campaign Cost a Record \$1.2 Billion," New York Post, December 9, 2016, http://nypost.com/2016/12/o9/hillary-clintons-losing-campaign-costa-record-1-2b/. Accessed April 11, 2017. 


\section{What shall we do?}

While it is true that advocacy ads do not regularly inform, attack ads also do not necessarily inform. And when they do inform, often claims are misleading and deceptive. Given this, negative ads can be more insidious than positive ads. When we see a negative ad, we gird ourselves for an unpleasant rhetorical attack, but in exchange we expect reliable negative information about the opponent, which we can consider in deciding how to vote. But more often than should be the case, we are disappointed.

I do not suggest that all negativity be removed from ads, as has been suggested elsewhere.$^{21}$ In distinguishing her record from her opponent's, a candidate must be able to mention her rival and his record, in order to make her own case for election. What I am suggesting is that this be done in the absence of distractions from the message. Music is just such a distraction. We might wish to return to a time when a political ad clearly contrasted with the programming that surrounded it, where there was just a talking head (or a couple of them) speaking directly to the camera. After all, campaigns don't play music during the candidates' remarks in a debate; why should they play music during political ads? That is, why should they play music unless their aim is for the tail to wag the dog?

Americans are not necessarily unaware of attempts to influence them surreptitiously, but they often lack the musical/semiotic sophistication to identify non-discursive appeals. Perhaps it is best to admit that music literacy can no longer be assumed among many segments of American society. Given this fact, we must acknowledge that voters will continue to be affected in ways they will not understand. Nevertheless, if a critical thinking curriculum could be applied to these pervasive ads, people would at least know intellectually their emotions are being manipulated, even if they do not understand how. Short of legislation banning the use of music, images, and sound effects in political ads (scarcely likely), this may be the only way to improve the situation.

Ideally, we would see critical thinking taught in civics and American history courses, including how to deconstruct political ads. This would require instruction in logic and argumentation so that students would recognize logical fallacies, but also in visual literacy and musical appeals to emotion. Even rudimentary instruction in music and exposure to the

21 Ben Perdue, governor of North Carolina, has pursued the possibility of public campaign funding precluding any mention of one's opponent (and therefore, precluding attack ads). 
idea that voters can be influenced by nonverbal appeals would do much to improve the chances for a robust democracy.

Regarding music's power to influence, philosopher and composer JeanJacques Rousseau said:

Music affects us more deeply [than painting], arousing through one sense feelings similar to those aroused through another [...]. And the musician's art consists of substituting for an imperceptible image of the object the movements which its presence excites in the heart of the contemplator. Not only will it agitate the sea, fan flames, and engorge a stream, but it will depict the horrors of a frightening wilderness, darken the walls of a dungeon, calm a tempest, subdue the winds, and the orchestra will lavish new freshness upon the forest. It does not represent these things directly, but excites in the soul the same feelings one experiences in seeing them. ${ }^{22}$

Taking Rousseau's words to heart, we would ideally consider leaving music in the realm of pleasure, keeping it separate from the rough-and-tumble world of politics. Sadly, my wish seems unlikely to come true. Nevertheless, the more citizens understand about how music is used to guide them toward one candidate or policy over the others, the better off we will be.

22 Jean-Jacques Rousseau, Two Essays on the Origin of Language, 64, as quoted in Emily Dolan, The Orchestral Revolution: Haydn and the Technologies of Timbre (Cambridge, UK: Cambridge University Press, 2013), 45. 


\section{Appendix 1}

\section{Interview with Jim Cole}

Cole is co-owner of media production company Gum Spirits Productions.

July 11, 2013

Paul Christiansen: So, Jim, I was wondering what got you into this kind of work, because most people enter it through communication studies/mediathat was my undergraduate background - I know that you studied art. Were you approaching it initially from a more aesthetic than technical perspective?

Jim Cole: I would say so. I was interested in art initially at a young age, starting in college and during college I started drifting more into broader, more liberal arts stuff-I got interested in history, a wider range of things. And then, more on my own time, I was primarily interested in filmmaking. By the end of school I was more doing that on my own, sort of checking the boxes with art, although I still loved doing it and was still serious about it, I felt that my attention was drifting elsewhere.

PC: So I assume studio art, as opposed to art history.

JC: Yes, studio art—painting, specifically. But I would say that I also had a relatively in-depth background in music, too, because my dad of course was a music professor and my brother is now a music professor and it's sort of in our family, and I played piano from a young age. When I would do a film project, I would write my own music and play in it and all of that. So I came at moviemaking with a particular interest in the interdisciplinary aspect of it. The visual aspect obviously related to the painting that I was doing, and I was interested in writing too, so that was part of it, and music was of course a big part of it, and editing in some ways is the most important part of making a film or commercial. I come at editing in a way that's really informed by music. There is a lot of focus on the interplay between the music and the image and rhythmic timing, crescendos, all that sort of thing. I think of it that way and I can't help it because music was what I had on my brain first.

PC: Well, it's so much a part of the film aesthetic, editing, isn't it? How can you have a film without giving careful thought to editing? One thinks of Eisenstein and what he did for film through innovations in editing ... 
JC: And that particular school of thought for filmmaking, the idea of montage that Eisenstein championed, is very related to the genesis of modern political advertising. Montage is more important in political advertising than in almost any other type of advertising, the juxtaposition of two images to create an effect, even if the viewer sometimes doesn't realize it's being created. And I would also say - we should talk more about this later-I think music in particular as one of the many elements in any sort of moving picture, commercial, movie, whatever ... for most audiences, especially audiences that aren't professional musicians, that is much harder for people to parse, I think. People are more able and inclined to analyze visual images, they're certainly more inclined to analyze parts like text and information that's coming at them. The music kind of sneaks in and makes an end-around. Most audiences don't even realize what is actually happening, but they somehow find themselves thinking, "Oh, I like this ad" or "I agree with this" or "I disagree." And sometimes it's just the musical sounds that are doing it. And if you strip the music out of it, you'd be left with a very unpersuasive ad.

PC: [nods profusely] In the published interview, you'll read "PC: [nods profusely.]"

JC: [chuckles]

PC: I mean, that's why I'm writing this book, because people who don't have musical training are just not equipped to understand what's being done to manipulate them.

JC: That's right. And I think music, more than any other element, is able to do that. For whatever reason, it's just like exposure to TV, movies, or whatever. Or written material. Most people are just more equipped to comprehend and break down and have some defense against visual images, text, and that sort of thing.

PC: And at least in my mind, even though there is some deficit there as well, audiences typically have a fair amount of visual literacy, whereas they tend to lack musical literacy.

JC: And that is interesting and I'll have to think a lot more about why that is. I'm sure you've been thinking about that more than I have. But I do think that's true. It seems to be true to me. So anyway, just to wrap up background stuff, I got out of school, made independent movies, for a while did a couple 
of features, mid-budget, but significant enough that we had Hollywood crews and all of that, and I still want to do that, that's still sort of my ultimate dream. But I realize now it's really more of a side hobby.

PC: You did that film with [former University of Southern Maine theatre professor] Minor Rootes, right? ${ }^{1}$

JC:Yes, I did. And then after that, based on the festival success of that, we got a half-million dollar budget and were able to do a Western out in Montana, and we had B-level actors, but still sort of name actors, professionally still a somewhat modest crew. So I had a chance to do a feature movie that way. But then when I was editing that, I realized I hadn't budgeted anything to pay myself at all. So I took some corporate video jobs on the side and that developed into a pretty thriving commercial business. But I was always more interested in politics, because I think at least some of the time it does have arguably social impact, so it felt a little more interesting to me at the time. Also, it turned out to be sort of recession-proof, just because people will always want to be elected things.

PC: Absolutely.

JC: And will always want their issues to come out on top. So it really doesn't disappear. So as a business, it's made sense to me. I'm still doing non-political advertising as well, but political is where our company is grounded the most. I say "we," because it is me and two other guys. Where we've grown the most, what I find the most personally interesting, still is now probably $80 \%$ of what we do, which has happened in the last three years. It went from $10 \%$ to $80 \%$ of what we do. Last cycle [the 2012 elections] we were really, really busy, and it's almost all political ads.

PC: Do politics dictate which kinds of ads you agree to produce? For instance, maybe you and your other two colleagues might have personal views that would make you say, "I'm not going to do a 'No on I' ad." Or so on.

JC: Within the confines of being generally partisan, which we first of all are personally and also have to be, because everyone asks, they'll want to

1 The 2005 film that Cole directed was called Sundowning.

2 Cole's firm produced a series of ads for the successful 2012 "Yes on 1" initiative in Maine to approve same-sex marriage. 
know who you work for, you can't just be a mercenary. I'm sure some people somewhere in the world do it, but it's not really workable. There are, I'm sure, lots of issues on which good, conscientious liberals could disagree, but we haven't been in that position too much. Pretty much it has been party-line stuff, so it hasn't been that hard to take or not take. It's more dictated by capacity, because we still are a small company. How much can we take on and still give people our full attention? One thing we don't do is subcontract out our editing. I do all the editing myself, I select all the music. If I don't write it, I find it. I film everything. We send a second camera in, but I'm there, so we don't have the capacity to do that many video campaigns at the same time. Not yet anyway.

PC: That makes sense. But you could envision being approached by, say, a 527 (tax-exempt) group where you might say, "No, just don't agree with that, so I'm not going to do that."

JC: Absolutely, absolutely. We've certainly been approached by ... I have to not use any names ... non-political clients that we have a good relationship with who want us to do some work, even a one-off sort of thing for someone, a candidate that is on the other side of the fence. That is still very moderate, not the most despicable person to me in the world, but we still wouldn't do it. Even if it would jeopardize the professional relationship, the non-political relationship, with someone who, say, is high up in an ad agency that had a branch that needed a production team. We just wouldn't do that. And honestly, even if no one would know that we produced it, even if it was through the layer of the ad agency, we still wouldn't want to do it. For ideological reasons, I guess.

PC: What do you think of recent political ads you've seen? I noticed that you produced ads for [US Senator from Massachusetts] Elizabeth Warren.

JC: We did her web videos. So we had a media consultant that did her TV ads that ran in Massachusetts. Frankly, at that point in time-and maybe it's debatable now - that was a little bit beyond our pay grade. We were not proven enough yet to take on a hotshot US Senate candidate race. We had done at that point much more ballot issues, less candidate work. That's changing now. But we were hired by her media consultant (who did her TV ads) to do her web ads. So anything that you would have seen on her site is a web video that we produced. And the media consultant was Mandy Greenwald, who did Hillary Clinton's campaign, she's pretty high up the 
ladder. So yeah, we did that. The biggest thing we did to date was the marriage initiative in Maine.

PC: Right.

JC: We were the media consultant for that, the Yes on 1, pro-gay marriage. And for that it was not just me being subcontracted to make videos, we were guiding the campaign ...

PC: Those were great ads, too, by the way.

JC: Thank you. That was a high point for us.

PC: What I liked about the campaign was that it was kind of a down home-this is what typical Mainers would think. Because my feeling is that although Mainers tend to be somewhat conservative in certain things, there is also a leave-well-enough-alone aspect to their character. To generalize.

JC: Exactly right. There's a certain streak of libertarianism to their conservatism. That core value of not wanting to tell someone else what to do. And not wanting to be told what to do. That's where that comes from, of course. And that was a construct that we used in those ads for sure.

PC: What do you think of political ads produced by other people? Have any stood out to you?

JC: I have very different feelings ad by ad. My first response is to be critical because I'm competitive and I want mine to be better than anyone else's. I think there is an unfortunate reliance sometimes — and this is just a subjective personal preference, but I also think it doesn't work as well-a reliance on a lot of text, a lot of stock images. I like ads that have real people in them. I tend to not want to do an ad that is just a few newspaper citations and scary music, a mono-level stylistic approach where you have an ad that is trying to scare people into not voting for something or someone. And you have, getting back to what we were talking about, scary music. It's exactly the same, it's like right on the nose. And I find that that is not as effective. As far as how I respond to music in ads: In film you would often try to do wistful music in a tragic scene or sweet music in a tragic scene. That sort of contrapuntal approach is lacking in a lot of ads. I miss that. But I think there is some amazing creative stuff. Some of the Obama ads were unbelievable 
(as they should be-he has the best people working for him). Particularly (this isn't strictly music) sound design. There was that one where the camera was panning through factories that Bain Capital had purchased and sold out and we had that audio of Romney singing "Oh say can you see?"

PC: Yes, I've written about that one.

JC: It's pretty amazing. So if I had to think about one last cycle, that was really ...

PC: And he is going out of tune ...

JC: He's going out of tune, and the reverb matches the space.

PC: Yes. The reverb is brilliant.

JC: So it's very genius.

PC: He's singing "America the Beautiful."

JC: Oh, "America the Beautiful," that's right. So I thought that was a pretty stellar ad. I don't like doing negative ads, especially doing an ad that feels negative, because no one likes watching them. People like to feel positive emotions. We should come back to that because I have more thoughts on that. A tricky thing, though, is that negative ads work. More than positive ones.

PC: Yes, and campaign consultant after campaign consultant will tell you the same thing.

JC: Exactly. You've got to thread the needle, though, because it's so easy to create a backlash and have the wrong effect and that ad, the Obama ad, was so effective. And it had a little bit of humor, of ribbing. You know what I mean?

PC: Absolutely.

JC: Music is able to communicate a lot in a way that people are not even fully aware of. But immediately you're right there with them. It reminds me 
a little bit of what you would do if you were trying to get your cat or dog to take a pill if they were sick, you'd put it in peanut butter or wrap it in one of those toys that taste delicious. It's almost like this delivery mechanism where you can ... well, "put one over on your audience" is probably not a tactful way to describe it, but it kind of does that. I generally do think that a positive emotion is more effective, whether it's nostalgia or credibility, core emotions that people want to feel, it gives them chills a bit. Or at worst like in a negative ad, "disappointment" — never anger, never hatred, disappointment. It makes you feel good about yourself. You know, "It's too bad, I like Romney, but he kind of disappointed me." And then you apply that sentiment to a particular position.

PC: Speaking about positive ads, I watch "Morning in America"4 and I still get chills, even though I am on the other side of the fence and I understand thoroughly how the music is supposed to work on me!

JC: Paul, I'll tell you, we had the most liberal client you would believe. We did an ad just after the election for HRC, for the Human Rights Commission, which is a national group promoting same-sex marriage or marriage equality. It was a big budget ad, we had Morgan Freeman do the voice-over, they had Hollywood connections and they got him to do it, and what they said was that they want this to be like "Morning in America." This is for same-sex marriage.

PC: It's an iconic ad.

JC: And it's in late 2012. And that's still the touchstone reference point. And that's exactly what we tried to do and it still works. It's stirring.

PC: You mentioned that you didn't want to go negative, and I understand that. But Bush's 2004 "Wolves" is the most remembered ad of that cycle.

JC: It works, yeah.

PC: And [George W. Bush campaign adviser Alex] Castellanos was quoted as saying, "We tested 'Wolves,' people got it immediately. 'Wolves, terrorists, we got it, threat, yep." So here is another question for you: Do you feel that

4 In this interview, "Morning in America" refers specifically to the 1984 Reagan ad entitled "Prouder, Stronger, Better." 
there is an ethical aspect to producing political ads? Because it seems that Castellanos is bragging that he is manipulating people.

JC: If you think you're not manipulating people, you're kidding yourself. That's the whole point. I think that the fulcrum for any ethical considerations is the candidate, the candidate's positions, or the issue. Do you believe it is an ethical issue? The means that you use to get there-short of obviously being dishonest, as long as you're being factual — any emotional manipulation beyond that is the exact reason we're in business. And that's why you have airtime. I don't feel great about it every time, but I think where you make the decision is do you want to do ads for this candidate? Because at the end of the day, it's really to influence policy, to elect someone, or to have an issue win. And that's where the ethical consideration is. Do you believe that this is a cause to get behind or a person to get behind? And if so, then you should do anything within the realm of being factually honest to make it happen. You can probably tell by the way I'm talking about it that I sometimes feel squeamish about that.

PC: Well, Aristotle acknowledges three means of persuasion, and $\pi \dot{\alpha} \vartheta_{0}$, appeal to emotion, is one of them. And a legitimate one, not in any way underhanded or out of bounds.

JC: I have felt the feeling before that something was over the line, irritating me-I'm trying to remember what it was. I'm interested in that, too- what was different about that ad. Because it wasn't factually incorrect. I think what made me uncomfortable was ... So a number of the ads we've done are independent expenditure ads, not for a candidate, they're for an issue, and often by a DC-based PAC coming into a rural part of the country, whether it's guns, or public option in health care, labor issues (we get a lot of that), and they love-and I love- to use real people. They'll identify a supporter, someone on their mailing list who is willing to be in an ad, and I think that's great. A person actually from the area, an actual voter. And often a person that has a compelling story to tell. But then they will write a script that is poll-tested language ...

PC: Frank Luntz-approved?

JC: [chuckles] ... and it's not exactly substantively different from the person's story, but it's a word they would never use and it pushes it into this more cutting rhetoric. And I feel bad, I often try to quietly soften the language a 
little bit. Because I do feel bad making someone say something in a way they wouldn't say it. That feels slightly unethical to me. And the reason groups like that do that, it's not exactly electoral politics- they're preaching to the choir, they're trying to rile up an aggressive base. So angry language works. It's not about winning over voters that are genuinely on the fence, and I guess I find that sort of thing, winning over persuadable voters, more appealing.

PC: So how do you choose music for ads? Do you compose your own or use pre-existing music or commission some? From what you've said it sounds like you write some of it.

JC: I do. Just for reasons of work flow and ease. Obviously in an election season we would have a lot going on. I try to find pre-existing music, some needle-drop music. There's a bunch of resources. I do have a pretty clear sense from reading a script what kind of music it's going to call for. And the types of music I would use normally fall into maybe four or five buckets of music that I think are going to work. There are kinds of ads that I think I can knock out of the park and do a good job on and seem to have worked in the past. So I try to find something that exists. We don't often commission because we don't often have time. Normally we have to have something done within a week, sometimes within a day or two. It is just not feasible to do that. And I don't think many people do that. Except at the highest budget levels and even then, I think probably not, I think it's needle-drop music for the most part. If I can't find something, then I will make it myself.

PC: It seems as though some music, like "Morning in America," was written specifically for the one purpose of matching with the images and the voice-over line by line.

JC: I think it probably was, but I think that was not a response ad, it was not in the heat of the campaign. And I don't know this historically-you should check it — but I'm guessing they had that in the works for a bit longer to roll out at the right time. And this may just be the specific races we've done, but we haven't had too much opportunity to do that. It's all been pretty quick. I would like to do that more to be honest. I would love to commission music. So generally I try to find something, if I can't find it, I will just create it at home, like a MIDI keyboard kind of thing.

PC: So a client will order an ad and you will know in the moment, what genre of music you want to use, what instrumentation you want to go with? 
JC: Actually, yes. It's the first thing I think about, along with the visual style to some extent, especially if I can think of an analogue, this is like "Morning in America" style ... or sometimes it's a movie, not an ad. Often I don't know if there's time to make it rocket science, so if it's the kind of thing that's going to have a string section that slowly crescendos, right at the very end at 26 seconds when the disclaimer comes off and it's going to have sort of a bass pulse that gets a little bit louder and usually I try to find or plan on a turn like halfway to $3 / 4$ of the way through when a barnburner line comes through ...

PC: The golden mean.

JC: I'm telling you, it's a physical reaction. People hear a big loud bass note, even if it's sub-frequency, people just feel "Ooh, what is happening?" Know what I mean? You can't help it.

PC: And they are most prevalent in the negative ads.

JC: Yes. And there are other considerations. Is it the kind of ad where we need an audio disclaimer? So someone has to say, "Paid for by ..." Or is it just a visual disclaimer? So does the music have to chill out earlier? Do they want text onscreen for a long time? What is the structure? Does it have sort of a prologue or leadup, so should the music be subdued and then come in at ten seconds or so? So you try to think about it around the script. But the tone is often similar. I don't like using creepy music in negative ads. And I always imagine the word "disappointed," and I can't tell you exactly what "disappointed music" sounds like, but it's distinctly different from, say, eerie, horror movie-style.

PC: I think I know what you mean.

JC: It makes a viewer feel better about themselves. They don't want to feel scared.

PC: I think people were ultimately turned off by the terror ads of the Bush campaign in 2004.

JC: And of terror in general. People were scared for so many years-it's almost like emotional exhaustion at a certain point. It's still effective, I guess, but it's off-putting. 
PC: It seems to me that Republicans early on saw and were willing to exploit the power of music in political ads. Democrats have been playing catchup all along. I think Clinton understood, and certainly Obama did. But Dukakis? McGovern? And Adlai Stevenson in 1956 didn't have music in his ads.

JC: I would conjecture that at a certain point in the history of the modern Democratic party, there was a certain entitled obliviousness that assumed that all voters naturally would agree with their perspective. Like of course this is right, it's common sense. And I agree with those things. And you don't need to use those dirty tricks. The idea sells itself. Which would be lovely if that was true, but I don't think it was and it still really isn't. And I don't think that Republicans were ever so burdened by that notion.

PC: It seems that Democrats feel embarrassed or ashamed to use manipulative tactics-they want to say, "These ideas just make logical sense" or instead of these tactics, they want to say, "Don't you people have compassion and decency?"

JC: As a Democrat I completely feel that way, too. I can relate to the impulse. But a key thing to remember always, and this was drilled into our heads in the same-sex marriage campaign in 2012, because it had lost in 2009, so you're familiar with the history of that, there was a major marriage initiative in Maine in 2009 and it failed. There's been a lot of soul-searching about what happened there. And what we found to be true-because we worked really closely with a research consultant and they did a ton of psychological research and polling before trying to win marriage in Maine-was that the problem with that is: who are you talking to? You're not preaching to the choir. There are lots of people who are going to vote for same-sex marriage in Maine, fine. The 2009 ads seemed to be more playing to those people. But they hadn't really considered that there's a different audience we need to be talking to, and it's not people that agree with us. And not everyone does agree with us. No, you've got to as a first step acknowledge that there are people who you may profoundly disagree with that you still need to persuade. You have to respect them, because these people are not hardcore ideological right-wingers who will never vote that way, I mean forget that. But there are people who disagree with you but are still fundamentally decent people and that are persuadable. So identifying that is the first principle.

PC: Of course marriage has always changed as an institution over the times. I have a friend, liberal on almost every issue, who just cannot accept 
same-sex marriage. He is all for civil unions and equal rights for everyone, but sees marriage differently.

JC: I'm telling you, that was the hardest thing in the whole campaign: how do you get around the civil unions thing, because people still feel good about that. They feel they are decent citizens and good liberals saying I support civil unions and everybody should have the same legal rights. But how do get them that extra step to say that it's not the same thing? What we emphasized to get at that was we had to go right at the emotional aspect. That marriage is emotionally different.

PC: There you go.

JC: You don't grow up dreaming that some day your son or daughter is going to have a civil union. You want someday to be at their wedding. We had to make purely an emotional appeal. People didn't like rational themes, we're never supposed to talk about fairness or legalities or anything like that. It was just that fundamentally it feels different. It's a different emotional and spiritual experience that everyone should be able to have. But that was a real evolution for the whole marriage movement. We did a lot of research to arrive at that point. But getting back to music, as I started thinking about that issue and particularly about selling it to people in Maine, which as we've said, can be conservative, particularly the parts of Maine we needed to reach were a little more conservative. Portland was going to be fine-we needed turnout, but it was going to be fine-and southern Maine in general. And thinking about what is the tone? What is the key emotion and what is the music that will evoke that? So I'm thinking about pride in the state of Maine, values in Maine. Don't tell us what to do, we won't tell you what to do. Fairness, integrity, all these sort of Yankee values. What feeling, that has nothing to do with marriage at all, is going to evoke those feelings? And it was nostalgia. That was sort of the core theme, which would seem to be an appropriate tone for a [same-sex] marriage ad, but weirdly it is. It really seemed to work. So a signature ad, one of the first ads that we did, was of this 8o-something-year-old man, a World War II vet. He was a fighter pilot, he has a granddaughter who has a same-sex partner that wanted to get married. ${ }^{5}$ And we filmed him with his big family at Mother's Day breakfast

5 The ad referred to here is "The Gardner Family in Maine-Why Marriage Matters Maine," available on YouTube, http://www.youtube.com/watch?v=gvJrmMK8Hlo. Accessed August 21, 2016. 
with everyone sitting around the table. They had no real script. He was eating, then he would talk for a minute ...

PC: I saw this one.

JC: And the clue to what makes this guy so appealing - it was nostalgia, American values. He's a vet, this charming old man, he has a Maine accent, and a northern Maine accent, he's from Washington County. And all you have to do is evoke that nostalgia, the way you would feel about this guy if you were seeing a documentary about World War II. Positive feelings and then you apply that to marriage. But you have to apply it right from the beginning, because people don't like feeling tricked. You can't have him talk for twenty seconds about his service and all of a sudden throw marriage in there, because then it feels like sleight-of-hand.

PC: So you start it right at the beginning?

JC: You have him look you right in the eyes and say this is what it's about and then you evoke all of those positive feelings. They can't help it. People leave the ad, anywhere on the spectrum, saying, "I may still not agree with this, but I like that guy. He's a sweet old guy. I wish he was my grandpa." You know what I mean? And you're left with a positive emotional feeling. And then you build that up in layers over the course of the thirteen ads we did, creating more of those positive impressions over and over again. And you still use the same music, by the way. Once you get that tone ... It was all subdued strings, very backgroundy-anthem feeling, it just felt like nostalgic old America, evocative of those values that everyone is comfortable with and would like to get back to in some ways. It is counterintuitive for marriage, but it just seemed right.

PC: Now did you write that music?

JC: I didn't. I was going to write music, that was my plan, and then I found a thing that was so perfect that I used it.

PC: So pieces in the public domain?

JC: You pay for the right to use it in broadcast. And then I did actually layer some additional strings over it in some places in certain ads that were a little more intense. So we never really used any negative stuff. We shot some, but 
we never used them. But certain ads that needed more punch, I would add a little more of a crescendo. So I'd use the existing chord progression and I would just build it deeper, like another layer or strength, a little bit of meat underneath. Just to augment what I already had.

PC: To what extent do clients influence what music is envisioned and ultimately used?

JC: Never in my experience do they influence what is envisioned. We don't really talk about it beforehand, and I don't really want to. And I don't like showing rough cuts that don't have music, or don't have even color correction, that aren't as polished, because sometimes they won't like something without even realizing why they don't like it. They're like, "Eh, it doesn't work." And oftentimes it's something that's going to be fixed anyway in the final draft and polished. They will sometimes kick music back and not like it. Only once or twice have I really gone to the mat on that and pushed back. I did with that Human Rights Commission ad, which was pretty high profile for us. It ran in DC, but it was aimed at a more national audience, and a liberal audience. It's not trying to influence any pivotal election.

PC: So it didn't only run in DC, did it?

JC: The way a lot of these go, they'll do a token buy in DC, but it's primarily for web. They want to show that they're putting it on air, putting some real money behind it so they get press. So maybe it'll run in DC and maybe one other market. That happens a lot with independent stuff. That was the ad they wanted to be like "Morning in America." So the music I used is not like "Morning in America," but it's evocative of the same sort of thing, and it was actually a little darker. They wanted imagery like the Constitution or Martin Luther King's March on Washington, they wanted all these big things, but also ideas in there of overcoming oppression, pretty grand stuff. So it was a little more epic, what I used. Not louder or percussive, but just ...

PC: Sweeping gestures.

JC: Sweeping gestures. Part of it was a melancholy tone, because you have to have this sense of overcoming the negative ...

PC: So maybe a feint to the relative minor ... 
JC: Exactly. Quite a bit of that. And then there's a key change halfway through and then it ends on a positive, triumphant note. The representative, the person who we were working with, I think is a really smart guy and a sensitive guy, but he's not a musician. And to him it just sounded too downbeat. He wanted something that was purely light without starting with the dark and moving into the light. And to me that robbed it of the poignancy.

PC: But see that's the thing. You wanted to have a narrative, a story to tell.

JC: Exactly. And so for that one, I played it for other people to be sure I wasn't crazy, and they seemed to like it. One of our partners didn't like it so much, but it's not really so much his area. So I said to the client, "This is better. I'll do something else if you want, but I really think you're going to find this is better, I think it's powerful, and I know it's not fully upbeat," so we agreed to do that. And it was the right choice obviously. I only fought that one because I liked the ad a lot. Often I'll just say "OK, I'll try something else." And clients, because they're not musicians, they shouldn't be expected to know. They won't talk in detail about what they don't want to hear. "We want more energy, more high energy." That's about as specific as you'll ever get.

PC: I have a friend who sometimes plays saxophone in local commercials. And he once had a client tell him, "I want it more orange" and he had to try to figure out what that the client meant by that.

JC: And that's only somewhat more inscrutable than "I want more energy." I guess "faster and louder." "Orange" is really crazy. I've never had that happen. But then, and this isn't just about music, but about any work for hire that is creative: You have to be a mind reader. You have to listen to someone who doesn't know anything about music or visual style or anything else say that it makes no sense to them. You have to say to yourself, well, what kind of person is this? What does "orange" mean to this guy?

PC: Yeah, they might think that that means something.

JC: But it might mean something totally different to someone else, yeah. And then once in a long while you play the card, "I understand that subjectively you don't love this, but in good conscience my job is to tell you what I think will be better, and this is my area, I would suggest that we try this out." And sometimes I just do two versions and play them side-by-side, one with 
theirs and one with yours. And sometimes they will say, "Oh, you're right. That is good."

PC: Could you give an estimate of what percentage of an ad's persuasion in your opinion comes from nonverbal appeals or even specifically from music? Maybe that is too difficult a question to answer.

JC:I think it's hard to separate specifically music from, say, visual style, and by that I mean "visual content," which is more accurate. If you're doing an ad with a person in it or a group of people delivering lines for the camera, it's like casting an actor-they have to be charismatic, they have to be likeable. If someone has the wrong face, or they're wearing glasses that are too thick, you're screwed-it's not going to work, no matter what kind of music you have in there for the most part. So all of those ephemeral aesthetic qualities including the music, lighting, the subject, the person, how their voice sounds, is it deep, is it too high — all of these things are important. I'm going to politely say, with respect to scriptwriters and pollsters who have more say in the content, say it's $50 \%$. I might even speculate that in some cases, it might be $80 \%$. No matter what you say, if you've got those elements in place and all working ...

PC: Vocal timbre [of the narrator] is important.

JC: And how does that relate to the music? Is the editing on pace with the music? Does it happen in a rhythmic way that is sensitive to the music? Do crescendos time with the moment when a key message is delivered? Or a cut? Or a transition from a wide shot to a close shot? Are all those sort of subliminal aesthetic things working together? Do you get that sort of holistic ...?

PC: Aesthetic unity?

JC: Yeah, exactly.

PC: Again, coming back to "Morning in America," Hal Riney's voice, the grain of his voice and how it relates to the music, is just so much a part of that ad.

JC: I have digitally lowered people's voices a semitone. To make them sound more authoritative. Or just added a little more bass below $8 \mathrm{o} \mathrm{Hz}$ or something like that. I do that all the time, you know what I mean? 
PC: What would you say about harmonic modulation in an ad?

JC: I think a well timed and well chosen modulation is the same as what I was talking about as a deep bass effect at a particular moment. There's a physical response to that that is primitive and irresistible. If you time that with the right moment of the text in the ad, you just have a response to it, you can't help it.

PC: Some tonal manipulation doesn't even qualify as a modulation per se, there is a moment at the end of the "Wolves" ad where the final F minor chord is digitally altered so that tones slide down microtonally to create a stomach-churning, sickening effect.

JC: Yes, that kind of "warping down." I have a low frequency sound effect I use sometimes, which is pretty much exactly that. It is barely even tonal, it's just a rumble. But it's a descending rumble. And it's so low you can barely even hear it. It was a sickening sort of effect. I've used that a few times. And you would barely even know — well, you might notice if you listened to it - but most people wouldn't even pick up that it was there. You would just have this weird feeling of unease for a second.

PC: So the reason I am writing this book is that I think people generally have a poor understanding of the ways music and soundscapes in general work on viewers of political ads. You were talking about an aesthetic unity, which I agree the best ads are, but I actually think that very often the other elements are responding to music. This is a new claim. When music is even mentioned in books by political scientists, sociologists, media scholars, and so on, it is usually as an afterthought. The ad is accompanied by such and such type of music and they just leave it at that. Their most careful analysis is almost always reserved for verbal rhetorical appeals and the visual style. But I think music demands attention in a way that the other elements have to subordinate themselves to.

JC: I would actually agree with that.

PC: For instance, that unsettling music in "Wolves" makes you feel bad through an emotional appeal; the narrator and written text tell you about whom you should feel bad, "Kerry and the liberals in Congress."

JC: That's exactly right. By very definition, making a political ad is hopefully a good collaboration and partnership with politicians and consultants who 
come from the world of politics, not from the world of anything aesthetic. And this is very different from people that are creative, and obviously you have to have both of those things working at a pretty high level. I don't know of many media consulting jobs that are really founded by people who have a creative background. And it's very often they contract it out. The company will advise on what the message is, the style, and all of that. But pretty much it is left to the production company (and they have no political background or political interests), so they're not really operating in tandem as much as they could. So it's really asking a lot of people who have political backgrounds to judge, they don't have much input on the music. We don't realize it sometimes. They might reject it, they might say "That's not good, do something else." But they don't go to their production company and say, "Here's the script. We would like this type of music." They have more feedback on the visuals, the people who are in the ads, the casting and all of that, because again, I think it's easier for people to parse or understand that sort of thing. They certainly have more, if not complete, control over the text. That gets lost in the shuffle, but it's incredibly important.

PC: And to me, in many ads music is the most important thing. So it's odd that it is scanted so much by scholars. It might be because of a general lack of musical literacy with which many people feel uncomfortable addressing music.

JC: It is. And the people who are actually choosing the music, especially in good ads, who are creative people with poetic sensibilities and who understand how effective that all can be. Those aren't the media consultants. They're not people that you would talk to if you were going to interview someone who printed the ads for whomever. I'm sort of unusual in the sense that I'm a partner in the company, but I also come from a creative background. I do it all, I choose the music myself. I think another guy who did that is Stuart Stevens, who did Romney's campaign. I believe he has a film or advertising background and a writing background and a nonpolitical ad background. So he was from the creative world and came into politics and not vice versa. He's written a couple of novels, I think he's done some filmmaking. I know that he has a background that is not the traditional path for a political consultant at all. He didn't start as someone's campaign manager or spokesperson or anything like that. He started out doing some pretty creative work. Getting back to the importance of music, I would suggest that the reason that it may be the most effective and the most impactful part is because it is the least understood and the least talked 
about. And again people don't have that understanding or natural defenses. People don't like being manipulated, they build up a resistance to any sort of manipulative image, text, phrase. But they don't have that immunity with music because they don't have the background or the education.

PC: I would just add that I don't have an immunity to it either-I just know what they're doing to try to manipulate.

JC: But if they were trying to use music to persuade you to vote for something you weren't too sure about or didn't feel great about, you'd have an immunity to it, right?

PC: Yes, I think so. Only because I know what is going on.

JC: That's right and you might say, I'm not crazy about this candidate, but I know enough about music to know I'm being played a little bit.

PC: Well, I'd like to thank you for taking the time to talk with me. This is fascinating stuff and will contribute greatly to the book.

JC: Thanks. It was my pleasure. 


\title{
Appendix 2
}

\author{
Interview with Matthew Nicholl \\ Nicholl is professor and chair of the Contemporary Writing \\ and Production Department at the Berklee College of Music \\ and former composer of music for political ads for Ronald \\ Reagan, George H. W. Bush, and Bob Dole. \\ August 26, 2013
}

Paul Christiansen: So how did you get into composing music for political ads?

Matthew Nicholl: My main active period was when I was living in Washington, DC, about 1986 to about 1990. What we did is, I was working for a guy named Demos Chrissos, who had a music production company in Georgetown. One of our clients was this team, these two guys who later split up but were still active in campaigns, a guy named Mike Murphy, who did Romney who was in Washington and the other guy was Alex Castellanos.

PC: I know those two names for sure. [laughter]

MN: We also worked for some other political consultants on the Democratic side. What usually happens in DC is that we always worked for the political consultant, who is working for the campaign manager, who is working for maybe the chief of staff. There's a lot of layers between us and the candidate. What usually happened, what was true then, was that there tended to be production companies and people who worked for Democrats and production companies and people who worked for Republicans. So in addition to doing a lot of the music, we also had a production company that assembled the advertising, so we would get the voice-over talent and we would produce the spot with the voice-over talent. We did a bunch of presidential campaigns. We did H. Walker Bush, we did Ronald Reagan spots in support of the President when the Iran-Contra scandal was happening, because right then they were having the trials. So there was a very famous spot, I forget the name of it, but it was this little six-year-old girl in this big, beautiful field in support of the President was the whole thing, it was kind of a landmark spot. I wish I could remember the name of it.

PC: This was during his second term ... 
MN: This was an image spot for Reagan.

PC: To sort of buff up his image?

MN: Yeah. I mean, Oliver North was on trial then. So ... And then we did Herbert Walker Bush, we did Bob Dole's. What is interesting about it is that it was me and this other guy writing all the music. We had a stack of synthesizers, we were using a Mac at that point with Performer, it was before digital Performer. So we were using a Kurzweil K250 and a rack of synths. And it was in a little room. At that point we were using $3 / 4$-inch video that we were synching to SMPTE time code, center-stripe time code burn-in. And Alex [Castellanos] or Mike [Murphy] would come in and we would have the video part of the spot on $3 / 4$-inch video, we would write it usually in a day, they would come in in the morning and they would have to get it up on the satellite the next morning or later that afternoon.

PC: Quick turnaround!

MN: Super-quick turnaround. Super-high pressure. And Mike Murphy would tell us what he wanted and we would kind of collaborate on this, we would do a simple demo, usually a piano demo, with maybe some light percussion or something, and then he would approve that and we would go ahead and orchestrate it. Most of these spots were your typical, you know, studio orchestra sound-strings, brass, that kind of stuff. There were soundtrack elements in terms of hits we had to catch as there would be in any soundtrack, "We want this cue here and this cue here, catch this kick here, don't worry about this one, this might change, the super[imposition] comes up here, we haven't got the slogan ..." It would all be verbal. And then we would do our best, and he would come and see it and maybe ask for a few changes or maybe approve it as it was. Then we would mix it. We had tie lines into the video editing facility downstairs, Capitol Video, so we would just say, “OK, you guys ready?” They'd say yes, and we would just pipe it down there. And then they'd lay it back to video. Things moved so fast. During the political season every two years we would be-I was only there for four years, so I did two campaign cycles-we would just be burning. And we also had other clients doing other stuff. We had [the] PBS National account. So every year we did a big syndicated package for PBS National, the TV stuff that they sent out everywhere, their legal ID, all of that stuff. 
PC: In an interview that I did with Jim Cole of Gum Spirits Productions, we talked about meaning in the music, like how much can you semiotically analyze the music for content as it relates to the images and voice-over and how much of it is just music that is temperamentally and atmospherically appropriate to the ad. What are your thoughts?

MN: It's hard to say. With us, it was always a seat-of-your-pants kind of thing. The guy I was working with was not a schooled musician. He was a good musician, a good songwriter, he could play piano and guitar and sing very well, but he didn't know harmony or theory. So we would write these things together. Lots of times I just wrote them myself, but sometimes if it was an important client we would write it together. When Bob Dole was running for the primary for his presidential Republican primary, Mike Murphy came to us and said, "You gotta warm this guy up. He comes across as stiff and cold." So my friend Demos sat down at the keyboard and did the sappiest kind of Hallmark music. And it worked perfectly with him because it ...

PC: Major, lots of suspended chords?

MN: Yeah, like a $\mathrm{C}_{2}$ chord, then $\mathrm{F}_{2}$, then A minor going down to $\mathrm{F}$, you know $\mathrm{G}$ sus going to a $\mathrm{G} \#$ diminished chord, this kind of sweet stuff, and they loved it. And actually we did a lot of follow-up spots. This was the video biography that they sent around to all the little local shops in support of him so that this was a teaser for before he would show up, they would play this thing, and it was about eighteen minutes long with music all through it, and it was all this sappy Hallmark stuff. We got a call from Mike Murphy's boss, who managed the whole campaign and said, "We love it, this is great." So we hit it, but it was not what you would think, it was really simple, emotional stuff.

PC: Jim Cole told me that occasionally a client wouldn't like the music he came up with and usually he then just changed it, but there were a couple of cases where he pushed back a bit, defending his choice as more effective than what the client had in mind. So did your clients sometimes want the music redone?

MN: Yeah. Most of the time ... well, let me put it this way: When we were working with Mike Murphy and Alex Castellanos, the first several campaigns we did ... we did Wyche Fowler for Congress, that was a big campaign, Richard Ravitch, who was running for mayor of New York, and we did a couple of congressional campaigns with them before they gave us the big 
stuff. So in those first ones there was a kind of dance of making sure we all understood the same terms. But boy, by the time we got to the heavy stuff, the spots we did for Reagan and Bush and Bob Dole, and we did Marion Barry when we was running, it was so fast. He would come in, we would play him a demo, and he would say, "Can you just make sure that when we get here that he has blah, blah, blah ..." and then we would finish it and he would come back for the mix and he would say, "Sounds great." Very rarely were there any changes because we had been through several iterations.

PC: Now were the ads for Marion Barry trying to rehabilitate his image after ...?

MN: Actually, the spots we did for Barry were for his 1986 re-election campaign, before he was arrested. His spots didn't have music, we just recorded his $\mathrm{V} / \mathrm{O}$ and edited it into thirty- and sixty-second radio spots. We were working for a local advertising agency who had Barry as a client. Mayor Barry was pretty interesting. That wasn't Mike Murphy, that was kind of a free-lance deal, he was local to DC and a Democrat.

PC: So I would ask you what importance you think music has in a political ad. Is it an element that holds things together, is it just background, or does it seem to channel the discourse? I'd like to know what you think.

MN: I think from a psychological standpoint, to use Buddhist terminology, it sets the feeling tone of the whole experience. And I think that probably more than anything else it cues the listener about their emotional reaction, what they should be feeling. Just like a film score. So this is not anything new. I don't think anybody is supposed to take away a factoid from those [ads]. What was very interesting for me was that ... I don't know what it's like where you live, but they hardly ever run any Republican ads in Boston. When [Republican candidate Scott] Brown was running [for US Senator from Massachusetts], we saw some of those, but the Democrats and Republicans concede Massachusetts. But I go to Cleveland a lot, because my mom lives in Cleveland, and there I would see all these ads and be bombarded by them.

PC: Now here's a question. Does political affiliation or sentiment figure into which clients you might accept, or is it more like "I'm a musician, it's a job?"

MN: Well, for us it was always a job. We really liked Mike Murphy. He's a brilliant guy. I see him in the paper commenting on things. And even back 
then, this was twenty years ago, he was just really smart and articulate. And he's really funny, just really witty, and working with him in the studio was a ball. And both he and Alex Castellanos were just really friendly, very nice people. So they hired us. We also did Democratic spots at the time, but there was always the problem with confidentiality when you're doing both Democrats and Republicans, because you'd have Democrats in the studio when you are recording the voice-over and the reaction to some Republican spot. So you'd have a client in the waiting room. It got wacky sometimes with these guys, because all these guys know each other. It's no secret. I think for the consultants, it's Democratic or Republican. For the production companies and the filmmakers, it was a little bit looser, and for us it was very loose.

PC: "Hey, they're paying me to write music, so ...”

MN: Yeah, making a living writing music - I mean, what's not to like about that? What I noticed about this last campaign with Obama is that there was one spot they ran against Obama where they colorized the film to make it look narrow and black and darker ...

\section{PC: Sort of sepia-toned?}

MN: But not a nice sepia. It made him look more African. And they lifted it almost entirely from the opening credit from [James Cameron's 1984 film] The Terminator. Almost exactly. And it's not the music credit, it's more ... if you recall the movie, the woman is looking at this playground, she sees her daughter swinging and the bomb goes off. It's a direct lift, and I can't believe it's an accident. Because Mike Murphy would always make funny jokes like [speaks in Mike Murphy voice], "This is our 'Terminator' ad," "Make him look like the Terminator." So that was our "bad guy" cue, "Don't trust him, you don't want him." And even all the talking, it was even more about the tone of the voice and the look of what you see on the screen, that's why I think, like I said, the "Buddhist feeling tone" is the key to all of this. The association of the dark negativity with the opposing candidate. And then there's the heartland spot, which is basically what we did prototypically for Dole, that sweet Americana, a little bit like Randy Newman's film score to The Natural, which was hugely influential. And then of course [Aaron] Copland's Fanfare for the Common Man. Those were the key milestones for political ads. 
PC: So sort of major, pandiatonic, open chords ...

MN: Major, not a lot of $\mathrm{V}^{7}$ - I progressions, but a lot of diatonic harmony.

PC: I'd love it if you could get into the weeds a little bit talking about the specifics of the music.

MN: One of the most used chords is that sus2 chord, because it's tonally neutral. We used to call it the "industrial chord," because you use it in so many situations where music has to be serious but not negative. The major sound is a little too pretty and plaintive sometimes, the minor tonality is a downer, but you've got to have a triad though, because the open fifth is too stark.

PC: So it's essentially two superimposed fifths, like $C-G-D$, which might be heard as CDG.

MN: Yes, it's usually as sus2. You can look at it as two open fifths, but the sound of it is to get the tension of the major second replacing the third, and that's why we call it the suspended 2 even though in classical harmony I don't know what they call it, an add 9 chord, no 3 rd or something. So harmonically, to be in the weeds a little bit more, there's a lot of major/ minor modal interchange. So you're in $C$ major, but you're using $\mathrm{A} b$ and $\mathrm{B} b$ chords, bVI, bVII. It's a huge way to cadence to the tonic, because one of the things I think you notice about this music is that it avoids typical harmonic functions. There are not a lot of secondary dominants, not a lot of V-I progressions, so you have to find other ways to make cadences. Cadences then typically become linear so that they occur in the bass. And you have the modal interchange chords, the chords borrowed from the parallel minor, subdominant minor, so bVI and bVII, that minor mixture, and then it resolves to that sus2 chord, so you get this hint of minor. There is the seriousness of minor, but there is no perky little third at the end. Except sometimes you do put the perky third in there.

PC: Yes, the sus2 is a kind of floaty chord ...

MN: Yeah, yeah. I think you could make the case that this would be true for a lot of product image spots. I did a lot of advertising. When I was in Texas for three or four years, I had the Radio Shack account. So we would do five image spots and fifteen product spots every year. And the image spots were 
the same thing: serious, but not minor. Not frivolous. They're all those kind of funny spots, stupid little cutesy spots, but image spots-Bill Bixby was the spokesperson back then, because this was the early eighties - and they all had that same kind of harmony. Just that what I call industrial harmony, mixture or major and minor, but no perky third. My point is that you might be looking for greater expertise and greater forethought than was really there. The guys doing this stuff, the turnaround was so quick, so it's their harmonic language, they're trying to create the harmonic and emotional energy that the client wants.

PC: But that might make my point even more forcefully, because especially when there is no time to think too hard about what you're going to do, you fall back on what you know will work on an emotional level. You revert to a comfortable and familiar musical language. I think practiced musicians have certain practices they go to for a particular feel.

MN: The ones I mentioned are, I think, the most common ones. When I was looking back at the last Obama campaign, they reused a bunch of tracks, they didn't do closed scores for everything. So they had a generic positive spot. Anyway, we didn't do a lot of syndication for our stuff. First of all, our stuff was cheap. We did such volume that we didn't need to make so much on each spot. So we were a bargain for them. Plus we worked so fast, they would come in in the morning, and bing bang, we'd have it done, so we did a lot of stuff for them. I know they had other producers working in New York for when they couldn't get to Washington on time. When those guys are on the campaign trail ... I don't know how they do it. You have to live and breathe it. So we did custom spots for everything. But I think when you are doing national buys like Obama was doing, I think they just bought the rights to these things. I would hope that the writer got some sort of reuse fee. Our stuff was always a buy-out.

PC: Unlimited use thereafter?

MN: Right. For some of it, we would do a license. We would say, "You can use it for this campaign, and then if you want to use it for another campaign, then you have to pay another licensing fee."

PC: I'm sure that you are familiar with these stock music sites like Audio Sparx and Audio Network, where you can go down the list, and people are writing stuff in their basement, and you can buy it one time for unlimited 
use in your campaign. You can even search with terms like "dark, foreboding, ominous, eerie."

MN: Yeah, that's really tough on a lot of the music houses. Actually, one of the guys I first started working for when I was writing music for media does that now, but by now after thirty years in the industry he has this huge library of campaigns for TV and radio stations. He syndicates TV and radio packages. He lays in the new vocals and stuff.

PC: You never wrote scores for this music, right?

MN: We didn't do scores. The way we did all that stuff was we would lock to picture, we didn't even do multi-track. I had a 24-track mixer. Back then there were no soft synths, it was all samplers and synthesizers. I had a Jupiter 8 in a rack, I had a bunch of Yamaha racks, a couple of Kurzweil racks. So we would lock to picture, we would find a tempo. Because that was the key - there was usually some sort of internal clock that had the energy that we wanted. And then we would write basically a piano demo that we would be synching to picture. So we were using the Kurzweils. We would play along with it, and then we would then get into where the double bars were, if there were $3 / 4$ or 5/4 bars, or how the visual structure broke down, we played some very simple harmonic rhythm and would divide the spot and usually there was a setup. You know, they have a three-part structure. They usually have the setup, then the stuff, and then there's the payoff. The people paying for this ... it's so expensive that they want to just cram it with copy. They want as much as possible, there's no time for development, for payoff. Blup, bing, and it's over! So that's when we'd call Murphy or Castellanos over and ask, "What do you think of this?" They'd say, "I really think this needs to be here because blah blah," then we'd rescore it and they'd say "Fine." Then we would replace that piano demo with the percussion, strings, brass, and all that stuff. We always scored the V/O like an instrument. You wanted to make sure that it had space and you had counterpoint to it. Most clients, by the way, think the music is too loud all the time. It's a general reaction.

PC: Interesting.

MN: So one of the things we would do is run the voice-over through a spectrum analyzer, see where the energy of the voice is, you run the mix through a spectrum analyzer, and you carve out that same place in the 
mix. So if the voice is at $200[\mathrm{~Hz}]$ with some sibilants at 4000 , you'd go down to 200 and put a nice dip in the track there and go up to 4000 and carve out a nice slice. Then you could push a little bit louder. Sometimes we also used a limiter so that when the voice was in it would push the music down a little bit, and when the voice was not in it, it would just gently come back up. So the most common change asked for by clients was to adjust loudness.

PC: Jim Cole mentioned that he was reluctant to show clients demos, because they would often raise concerns that were going to be moot after postproduction. So he prefers to show finished product (or close to it). But you showed your clients works in progress?

MN: They asked for it, we had to do what they wanted. But yeah, that's been a problem forever! Showing them a demo.

PC: And having them imagine what they thought it might turn out to be, which is different from what you plan to do ...

MN: Or sometimes they like the demo better than the final. After you've spent $\$ 2000$ putting a string section in and real bass and real drum set on there! Clients can't usually make the imaginative leap between what the demo is and what the final is going to be. These things are competitive-you have to turn it around fast. They are looking at a bunch of different houses, and they expect a finished demo. They expect the demo to sound pretty darn good. So you've got to compete on that level. They might have three or four people submitting for it. There is also salesmanship involved, too, you have to sell them on value added to take it form demo to finished. So there's a fine line there.

PC: How important to clients is instrumental color, timbre-antique cymbals, French horn, oboe?

MN: One of the biggest adjustments I had to make was to realize that the Mike Murphys and the Alex Castellanoses of the world have no musical training. They completely lack the musical vocabulary. But! They are really smart, and they are very intuitive about media. You just have to figure out what they're saying. I did a promo for the Nightly News on PBS. They did this big montage thing. I didn't realize this at the time, but this was actually an audition for PBS. They actually paid for it, but they were checking us out. 
And so I did this really interesting 12/8 music that modulated. This one we had a couple of days on, so I spent a lot of time.

PC: Hey, I get it - this is PBS, these people are sophisticated!

MN: And we're in Washington, right? I actually did a score for it as I would for an acoustic piece and then mimicked it. Then she came and said, "Wow, it's ... it's just a little too dark." My inner dialogue was, "It's perfect." She said, "There's just something about it. If there's some way it could be a little bit lighter." So I said, "Well, let me talk to Demos." So we went into the next room with Demos and I said, "Let's take the whole thing and transpose it up a minor third."

PC: You didn't!

MN: I did! So I came back and said, "You're going to love this."

PC: You primed her to like it.

MN: We went back out, played the transposed version, and she loved it. Didn't change a thing, except I had to change a couple of notes in the bass just slightly. She was ecstatic. And then she came back the next week and said, "We'd like you to do our legal ID and our promo pack for this year." We did that for four years.

PC: Did you tell her later on?

MN: No. I don't even know where she is now or where she works. And besides, the point is that it worked for her!

PC: Right.

MN: Well, [political ads] have a pure emotional appeal. They are looking for a visceral reaction. There's a Pavlovian element to it. They want to cue you: when you see this guy's picture, when you hear his name, this is how you're supposed to feel.

PC: Sure. 
MN: Another interesting aspect to ad creation is whether you are being asked to write prescores or postscores. Some of the people we worked for-not so much for the political campaigns, but the non-political stuff-really wanted the music first to edit the pictures to the music. Sometimes the video cats would want the structure of the thing to hang their picture on, whereas the political stuff we did was the other way around. There is a neurologist who I like very much named Rick Hanson, and he has this saying, "The neurons that fire together, wire together." So there's no doubt that when you are firing threatening images with the candidate's name and the whole fight-or-flight thing ... that's why I think negative advertising is so much more powerful than positive advertising in political campaigns. Because the positive stuff does not fire in our lizard brain. We did do a lot of positive stuff, but so much of the advertising we did was a reaction: "He is down in the polls two percent, and they just did a spot on how he is weak on schools and he doesn't support the police. We made this spot and we need this up on the air by ... can you have it by 5 o'clock?" So much of it was a reaction, when there wasn't even an overarching vision for what the campaign had to be. It was just, "You just gotta get this guy elected."

PC: A seeming exception to this rule is "Morning in America," which was such a well-planned, well-executed, and disciplined campaign.

MN: For sure. I think we can see how Obama was brilliant with how we worked those swing states. And I think social media changed a lot of stuff.

PC: And the web ads like the "Yes, We Can" ad with will.i.am and Scarlett Johansson and so on.

MN: And voice-over artists are just as important as the music.

PC: Well, I wanted to interview you as a practitioner, and I think your insights will be invaluable to this book. Thank you for your time.

MN: Thanks. 


\section{Glossary of Selected Musical Terms}

\begin{tabular}{|c|c|}
\hline A cappella & sung without instrumental accompaniment \\
\hline Accent & $\begin{array}{l}\text { prominence of one or more notes created by an increase in } \\
\text { duration or volume }\end{array}$ \\
\hline Ambitus & range of a melody \\
\hline Ametric & not in a regular meter \\
\hline Anhemitonic & lacking half steps \\
\hline Arpeggiation & the practice of playing chords in broken fashion \\
\hline Authentic cadence & musical closure of a dominant chord moving to the tonic $(\mathrm{V}-\mathrm{I})$ \\
\hline Cadence & a melodic or harmonic progression comprising a musical close \\
\hline Chord progression & a chain of chords that have musical coherence together \\
\hline Chromatic & $\begin{array}{l}\text { referring to an octave of twelve semitones (rather than a seven- } \\
\text { tone diatonic scale); containing notes foreign to the home key of } \\
\text { a passage }\end{array}$ \\
\hline Chromatic mediant & mediant that has been altered from its diatonic form \\
\hline Compound meter & $\begin{array}{l}\text { a time signature in which beats are divided into three instead of } \\
\text { two parts }\end{array}$ \\
\hline Consonant & $\begin{array}{l}\text { a tone that sounds harmonious with one or more other tones, } \\
\text { related to the sympathetic vibrations of their respective } \\
\text { frequencies }\end{array}$ \\
\hline Countermelody & a secondary musical line that combines well with the primary one \\
\hline Deceptive cadence & $\begin{array}{l}\text { harmonic movement from the dominant to an unexpected chord, } \\
\text { usually the submediant }\end{array}$ \\
\hline Diatonic & $\begin{array}{l}\text { deriving from a particular arrangement of whole and half steps; } \\
\text { characteristic of the major and natural minor scales as well as the } \\
\text { church modes }\end{array}$ \\
\hline Diddley-bow & $\begin{array}{l}\text { chordophone with a single string; associated with the American } \\
\text { South }\end{array}$ \\
\hline Diegetic music & music whose source is onscreen, played or heard by the characters \\
\hline Dies irae & $\begin{array}{l}\text { originating in the Middle Ages, a sequence from the Mass for the } \\
\text { Dead }\end{array}$ \\
\hline $\begin{array}{l}\text { Diminished seventh } \\
\text { chord }\end{array}$ & a tonally unstable chord made of stacked minor third intervals \\
\hline Dissonant & discordant, clashing \\
\hline
\end{tabular}


Dominant

Dominant of the subdominant

Drone

Drum cadence

Dynamics

Fifth

Fourth

Fundamental

Glissando

Half step

Harmonics

Jig

Leading tone

Major key

Measure

Mediant

Meter

Metrical
In tonal music, the fifth scale degree of the minor or major scale, the chord based on the fifth scale degree, or the key that is most often contrasted with the tonic key. The most important musical cadence is from the dominant triad or dominant seventh chord to the tonic triad.

The dominant chord of the triad based on the fourth scale degree. Most often a dominant seventh chord, written as $\mathrm{V}^{7} / \mathrm{IV}$. a sustained pitch heard in a section of music, often, though not always, in a low register steady percussion rhythm, associated with military marches, where the rhythmic patterns allow soldiers to march in step intensity of volume of a pitch or section of music the interval separating two notes that are four degrees apart on the diatonic scale

the interval separating two notes that are three degrees apart on the diatonic scale

the lowest tone in a harmonic series rapid scalar passage where the fingertips or fingernails glide across keys or strings

the interval between any two adjacent notes on a piano

\section{(See Chord progression)}

collection of notes whose frequencies are related by ratios of whole numbers; also, special effects on string instruments where a node lightly fingered produces a high flute-like tone polyphonic texture in which all parts move at roughly the same time; alternatively, melody with chordal accompaniment dance with beginnings in the British Isles; over time, it has become associated most closely with Ireland in an ascending minor, harmonic, and major scale, the seventh degree, which tends strongly toward the tonic diatonic scale in which the pattern of whole and half steps is WWHWWWH; an example is the $\mathrm{C}$ to $\mathrm{C}$ octave of the white notes on a piano

the metrical unit enclosed between two bar lines on a staff in a major or minor scale, the third degree (between the tonic and dominant)

collecting of beats into patterns within measures; a downbeat marks the beginning of a measure

pertaining to meter 
Minor key
Minor second
Modal progression
Modality
Mode

Modulation

Monophonic

Motive

Motto

Musical allusion

Musique concrète

Natural minor

Neapolitan chord

Neotonal

Non-diegetic music

Octave diatonic scale in which the pattern of whole and half steps is WHWWHWW; an example of natural minor is the A to A octave of the white notes on a piano

(See Half step)

succession of chords comprised of tones from a mode

musical system based on church modes

in contrast to major and minor tonality, a non-tonal scale that contains the melodic and harmonic material for a passage; some modes overlap with tonal scales (e.g., Aeolian mode is the same as natural minor); also known as church mode clear and unequivocal change of key (in contrast to Tonicization) texture of one voice without harmonic accompaniment or melodic counterpoint

brief musical idea with a characteristic harmonic, melodic, or rhythmic profile

a recurring motive, often very short

reference to another piece of music (or standard practice or style); beyond mere quotation, a musical allusion creates meaning through the comparison between a particular work and the work being referenced

type of experimental music in which sounds can be divorced from their sources; in this genre, the human voice, musical instruments, environmental sounds, and electronically generated sounds are combined. Traditional conventions of melody, harmony, meter, and rhythm are not observed; instead, the focus is on sound in the abstract

form of the minor scale that has no tones altered from the key signature

major triad formed by lowering the root of a $\mathrm{ii}^{\circ}$ chord in minor; the sound of the Neapolitan chord is often described as mysterious or surprising

twentieth-century music that is not tonal per se but in which tonal elements are used in novel ways; most commonly, a central chord is advanced through tonal assertion rather than through harmonic progression

underscoring meant to generate emotion for a film or television scene

interval separating two notes that have the same name and are seven degrees apart (e.g., $\mathrm{C}_{2}$ to $\mathrm{C}_{3}$ ) 
Orchestration

Ostinato

Pandiatonicism

Parallel major

Parallel minor

"Patriotic music"

Pentachord

Pentatonic

Phrasing

Pianissimo

Piano

Plagal cadence

Pointillistic

Polyphonic

Predominant

Register

Relative major

Relative minor

Resolution

Reverberation

Riff

Ritardando

Rubato

Second

Semicadence

Semitone

Seventh

Sforzando art of blending a group of instruments to create a pleasing

balance; setting musical passages for a group of instruments such as an orchestra or brass quintet

exact repetition of a melodic and/or rhythmic pattern while other musical aspects are changing in relation to it

the presence of other tones of the scale in a chord within a

diatonic context

major key having the same tonic as a particular minor key

minor key having the same tonic as a particular major key

music meant to stir emotions for one's country

musical system made up of five tones, most specifically the anhemitonic pentatonic scale (one example is the black keys on the piano)

a segment of a scale consisting of five notes (e.g., D-A)

how musical phrases are divided up during performance

at a very soft volume

at a soft volume

harmonic motion from the subdominant to the tonic

in an analogy to painting, denoting a sparse deployment of tones in a musical texture

texture characterized by two or more independent but

complementary musical lines

chord that precedes the dominant chord, most commonly the

subdominant or supertonic

pitch range (high, medium, low)

major key with the same key signature as a particular minor key minor key with the same key signature as a particular major key easing of harmonic or melodic tension, ambiguity, or dissonance persistence of a sound after the initial attack of the sound; reverberation can be enhanced in the studio using various electronic effects

brief melodic unit that is repeated and sometimes varied gradual slowing down of tempo variance tempo for expressive purposes interval between two adjacent notes on a diatonic scale (See Half cadence) (See Half step) interval separating two notes that are six degrees apart on the diatonic scale sudden accent on a note 


\section{Simple meter}

Sixth

Staccato

Stinger

Stress

Subdominant

Subito

Submediant

Supertonic

Sus2 chord

Suspension

Syncopated

Tessitura

Tetrachord

Theme

Third

Tierce de Picardie

Timbral

Timbre

Tonal

Tone cluster

Tonic time signature in which beats are divided into two parts $(2 / 4,3 / 4$, 4/4)

interval separating two notes that are five degrees apart on the diatonic scale

an articulation where successive notes are played with separation from each other

tutti chord on the second beat of the last measure that lends a sense of finality to the end

(See Accent)

in tonal music, the fourth degree of the minor or major scale; it is the degree of which the tonic is the dominant

suddenly

in tonal music, the sixth degree of the minor or major scale in tonal music, the second degree of the minor or major scale triad with a second instead of a third ; the second often resolves to a third

dissonance that resolves downward by step; usually it is introduced as a consonance and becomes dissonant when it is held over the bar and the bass moves accenting weak beats within a metrical structure in which the strong beats are felt but de-emphasized general range, usually vocal, in which a piece, part, or passage lies a group of four notes, often the notes fitting within a perfect fourth interval

material on which a musical movement or work (or part thereof) is constructed, often implying harmonic background, articulation, and instrumentation, thus not merely a melody interval separating two notes that are two degrees apart on the diatonic scale an ending in which a piece in minor ends on the parallel major chord pertaining to timbre sound quality of a tone, manifest primarily by various emphases of particular overtones; a viola and oboe playing the same pitch at the same volume have different timbres in relation to the major/minor system two or more adjacent chromatic notes sounding at the same time in tonal music, the home key of a piece, the triad that is the basis of the key, the name of the first scale degree 
Tonicization establishing a new tonic by means of its leading tone and usually also its fourth degree

Transposition transference of a musical passage from its original pitch level to a higher or lower one

Triad chord made of two stacked thirds

Tutti all instruments playing

Underscoring quiet music providing an atmosphere for dialogue in a scene

Unison two or more voices and/or instruments sounding the same pitch or melody simultaneously

Webernesque in the style of dodecaphonic composer Anton Webern

Whole tone interval consisting of two half steps 


\section{Bibliography}

Ansolabehere, Stephen, and Shanto Iyengar. Going Negative: How Attack Ads Shrinkand Polarize the Electorate. New York: Free Press, 1995.

Aslan, Mubeen M. "Are You Selling the Right Colour? A Cross-Cultural Review of Colour as a Marketing Core." Journal of Marketing Communications 12/1 (2006): 15-30.

"The Art of Buying Time." Campaigns \& Elections. June 2010.

Ball, Philip. The Music Instinct. Oxford: Oxford University Press, 2010.

Barone, Brian. “'I've Been Everywhere': Martin O'Malley and the Many Meanings of the Guitar," Trax on the Trail, January 7, 2016,

http://www.traxonthetrail.com/article/“i've-been-everywhere"-martin-o'malley-and-manymeanings-guitar. Accessed August 18, 2016.

Barreto, Matt A., Jennifer Merolla, and Victoria Defrancesco. "Multiple Dimensions of Mobilization: The Effect of Direct Contact and Political Ads on Latino Turnout in the 2000 Presidential Election." Journal of Political Marketing 10, no. 4 (2011): 303-27.

Barthes, Roland. Mythologies. Translated by Annette Lavers. London: Paladin, 1971.

__ - "The Grain of the Voice," Image_-Music_-Text. Translated by Stephen Heath. New York: Hill and Wang, 1978.

Benjamin, Walter. "The Work of Art in the Age of Mechanical Reproduction." In Literary Theory: An Anthology, eds. Julie Rifkin and Michael Ryan. Oxford: Blackwell, 1998.

Berger, Arthur Asa. Popular Culture Genres: Theories and Texts. Newbury Park U.a.: Sage, 1992.

Bernays, Edward L. Crystallizing Public Opinion. New York: Ig Publishing, 2011. Reprint from 1923.

Binet, Les. "Sensum — Goldsmiths Study on the Effectiveness of Music in Advertising," 7 March, 2014. https://www.youtube.com/watch?v=TzZsUMdBQQQ. Accessed July 9, 2016.

Birnbaum, Jeffrey H., and Thomas B. Edsall. "At the End, Pro-GOP 527s Outspent Their Counterparts." Washington Post, November 6, 2004.

Borstelmann, Thomas. The 1970s: A New Global History from Civil Rights to Economic Inequality. Princeton: Princeton University Press, 2012.

Brader, Ted. Campaigning for Hearts and Minds: How Emotional Appeals in Political Ads Work. Chicago, IL: University of Chicago Press, 2006.

Brinkley, Douglas. The Unfinished Presidency:Jimmy Carter's Journey Beyond the White House. New York: Viking, 1998.

Bruni, Frank. "The Millions of Marginalized Americans." New York Times, July 25, 2015, http:// www.nytimes.com/2015/07/26/opinion/sunday/frank-bruni-the-millions-of-marginalizedamericans.html). Accessed July 30, 2015.

Bush, George H. W. "Remarks at a Republican Party Fundraising Dinner in Richmond, Virginia," June 21, 1989, The American Presidency Project http://www.presidency.ucsb.edu/ ws/?pid=17190. Accessed August 23, 2016.

Campbell, Tracy. Deliver the Vote: A History of Election Fraud, an American Political Tradition, 1742-2004. New York: Carroll and Graf, 2005.

Carroll, Noël. The Philosophy of Horror. New York: Routledge, 1990.

Center for American Women and Politics (CAWP) Fact Sheet, www.cawp.rutgers.edu/fast_facts/ voters/documents/genderdiff.pdf.

Chambers, Francesca. "Is America's toughest prosecutor acting on the Clinton Foundation? Preet Bharara, scourge of corrupt NY pols, 'investigating' family charity," Daily Mail, August 12, 2016, http://www.dailymail.co.uk/news/article-3736807/ 
Is-America-s-toughest-prosecutor-acting-Clinton-Foundation-Preet-Bharara-scourgecorrupt-NY-pols-investigating-family-charity.html. Accessed August 18, 2016.

Charnin, Richard. Matrix of Deceit:Forcing Pre-Election and Exit Polls to Match Fraudulent Vote Counts. CreateSpace, 2012.

- - "The Primaries: Hillary Wins the Lottery," https://richardcharnin.wordpress. com/2016/05/12/the-primaries-hillary-wins-the-lottery/ Accessed August 14, 2016.

Chew, Geoffrey. “Monteverdi, Claudio: Works from the Venetian years." In Oxford Music Online. Edited by Laura Macy. Oxford: Oxford University Press, 2008.

Chion, Michel. The Voice in Cinema. New York: Columbia University Press, 1999.

Cho, J. "Political Ads and Citizen Communication." Communication Research 35, no. 4 (2008): 423-51.

Christiansen, Paul. 'It's Morning Again in America': How the Tuesday Team Revolutionized the Use of Music in Political Ads," Music and Politics 10/1 (2016). http://quod.lib.umich.edu/m/ $\mathrm{mp} / 9460447.0010 .105 /-$-it-s-morning-again-in-america-how-the-tuesday-team?rgn=main;v iew=fulltext. Accessed August 31, 2016.

_- . "Listen to the Music: It's What Campaign Strategists Want You to Do." Portland [ME] Press Herald. October 22, 2012.

_—. "Musical Yearning in Bernie Sanders's Presidential Primary Ad 'America'," Trax on the Trail, http://www.traxonthetrail.com/article/musical-yearning-bernie-sanders's-presidentialprimary-ad-"america", February 2, 2016.

Christoffersen, John. "Romney's ‘ $47 \%$ ' chosen as year's best quote," USA Today, December 14, 2012, http://www.usatoday.com/story/news/nation/2012/12/og/romneys-47-percent-chosenas-years-best-quote $/ 1756833 /$. Accessed December 30, 2015.

Clift, Eleanor. "Capitol Letter: Fighting a Phony War," Newsweek, August 19, 2004, http://www. newsweek.com/capitol-letter-fighting-phony-war-125999. Accessed August 31, 2016.

"CNN's Chris Cuomo: Media Has Given Hillary Clinton a 'Free Ride," YouTube, https://www. youtube.com/watch?v=SkXkS70Co-o. Accessed August 12, 2016.

Comey, James. "Congressman Chaffetz asks Comey about the Clinton foundation," YouTube, https://www.youtube.com/watch?v=-CSvtTyiTE8. Accessed August 18, 2016.

Conason, Joe. "Republicans' Dishonorable Charge," Salon, August 6, 2004, http://www.salon. com/2004/08/07/mccain_on_swift_boat_veterans/. Accessed August 31, 2016.

Cook, Nicholas. Analysing Musical Multimedia. Oxford: Clarendon Press, 1998.

Cosman, Bernard, and Robert Jack Huckshorn. Republican Politics: The 1964 Campaign and Its Aftermath for the Party. New York: Praeger, 1968.

Cracknell, Andrew. The Real Mad Men: The Renegades of Madison Avenue and the Golden Age of Advertising. Philadelphia: Running Press, 2011.

Cummings, Milton C., and Paul Tillett. The National Election of 1964 . Washington, DC: Brookings Institution, 1966.

Dalton, Philip, and Charlton McIlwain. "Third-Party 'Hatchet' Ads: An Exploratory Content Study Comparing Third-Party and Candidate Spots From the 2004 Presidential Election." Atlantic Journal of Communication 19, no. 3 (2011): 129-51.

Davies, Philip John, and Bruce I. Newman. Winning Elections with Political Marketing. New York: Haworth Press, 2006.

Davis, George. Music-cueing for Radio-drama: A Practical Treatise on the Application of Music to the Radio-script. New York: Boosey and Hawkes, 1947.

Deaville, James. "Selling War: Television News Music and the Shaping of American Public Opinion." ECHO: A Music-centered Journal 8, no. 1 (Fall 20o6). http://www.echo.ucla.edu/ Volume8-Issue1/roundtable/deaville.html. Accessed July 15, 2013. 
Dennis, David B. “'Honor Your German Masters': The Use and Abuse of 'classical' Composers in Nazi Propaganda." Journal of Political and Military Sociology 30, no. 2 (2002): 273-95.

Devlin, L. Patrick. "Analysis of Presidential Primary Campaign Commercials of 2004." Communication Quarterly 53, no. 4 (2005): 451-71.

_—. "Contrasts in Presidential Campaign Commercials of 1972." Journal of Broadcasting 18 (1973-74): 17-26.

_—. "Contrasts in Presidential Campaign Commercials of 1992." American

Behavioral Scientist 37 (1993): 272-9o.

_—. "Contrasts in Presidential Campaign Commercials of 2004." American Behavioral Scientist 49, no. 2 (2005): 279-313.

Diamond, Edwin. “The City Politic: November Song," New York Magazine (November 6, 1972).

Dusenberry, Phil. Interview with Jim Lehrer for PBS's Online Newshour http://www.pbs.org/ newshour/bb/media/july-decoo/image_8-3.html. Accessed March 13, 2014.

Edmunds, Neil. Soviet Music and Society under Lenin and Stalin: The Baton and Sickle. New York: Routledge, 2004.

Election Justice USA. "Democracy Lost: A Report on the Fatally Flawed 2016 Democratic Primaries," http://www.election-justice-usa.org/Democracy_Lost_Update1_EJUSA.pdf. Accessed July 29, 2016.

Eliot, Marc. Paul Simon: A Life. Hoboken, NJ: Wiley, 2010.

"Empathy represses analytic thought, and vice versa: Brain physiology limits simultaneous use of both networks." Press release from Case Western Reserve University, 30 October 2012, http:// www.eurekalert.org/pub_releases/2012-10/cwru-era103012.php. Accessed March 18, 2015.

Feltus, William J., Kenneth M. Goldstein, and Matthew Dallek, Inside Campaigns: Elections through the Eyes of Political Professionals. Thousand Oaks, CA: CQ Press, 2017.

Fisk, Josiah, ed. Composers on Music: Eight Centuries of Writings, $2^{\text {nd }}$ ed. Boston: Northeastern University Press, 1997.

Frank, Thomas. Listen, Liberal, or What Ever Happened to the Party of the People? New York: Metropolitan, 2016.

- - The Conquest of Cool: Business Culture, Counterculture, and the Rise of Hip Consumerism. Chicago: University of Chicago Press, 1997.

Franz, Michael M. Campaign Advertising and American Democracy. Philadelphia: Temple University Press, 2007.

Fredericks, Bob. “Hillary Clinton's Losing Campaign Cost a Record \$1.2 Billion," New York Post, December 9, 2016. http://nypost.com/2016/12/o9/hillary-clintons-losing-campaign-cost-arecord-1-2b/. Accessed April 11, 2017.

Freeman, Steven F., Joel Bleifuss, and John Conyers, Jr. Was the 2004 Presidential Election Stolen?: Exit Polls, Election Fraud, and the Official Count. New York: Seven Stories, 2006.

Freud, Sigmund, Josef Breuer, James Strachey, and Anna Freud. The Standard Edition of the Complete Psychological Works of Sigmund Freud. London: Hogarth Press, 1955.

Fries'dat, lulu, Anselmo Sampietro, and Fritz Scheuren. “An Electoral System in Crisis," July 25, 2016, http://www.electoralsystemincrisis.org. Accessed August 13, 2016.

Gallup. "Presidential Approval Ratings_-George W. Bush," www.gallup.com/poll/11650o/ presidential-approval-ratings-george-bush.aspx. Accessed August 1, 2016.

Garfunkel, Art. “Art Garfunkel on Sanders Ad Using 'America,'” Interview with Michael Smerconish on CNN, January 23, 2016, http://www.cnn.com/videos/tv/2016/o1/23/exp-garfunkel-onsanders-ad-using-america.cnn. Accessed August 18, 2016.

Geer, John G., and James H. Geer. "Remembering Attack Ads: An Experimental Investigation of Radio." Political Behavior 25, no. 1 (2003): 69-95. 
Geer, John Gray. In Defense of Negativity: Attack Ads in Presidential Campaigns. Chicago, IL: University of Chicago Press, 2006.

Gerber, Alan S., James G. Gimpel, Donald P. Green, and Daron R. Shaw. "How Large and Longlasting Are the Persuasive Effects of Televised Campaign Ads? Results from a Randomized Field Experiment." American Political Science Review 105, no. 1 (2011): 135-50.

Gilens, Martin and Benjamin I. Page. "Testing Theories of American Politics: Elites, Interest Groups, and Average Citizens," Perspectives in Politics 12/3 (2014): 564-81.

Gorbman, Claudia. Unheard Melodies: Narrative Film Music. London: BFI Publishing, 1987.

Graakjær, Nicolai Jørgensgaard. "Musical Meaning in TV-Commercials: A Case of Cheesy Music.” Popular Musicology Online-ISSN 1357-0951. 2006. Accessed January 04, 2012. http://www. popular-musicology-online.com/issues/05/nicolai-01.html.

Green, Donald P. and Alan S. Gerber. Get out the Vote: How to Increase Voter Turnout. Washington, DC: Brookings Institution Press, 2008.

Grim, Ryan."Harry Reid On Bernie And The DNC: 'Everybody Knew That This Was Not A Fair Deal'," Huffington Post, July 27, 2016 http://www.huffingtonpost.com/entry/harry-reidbernie-sanders-dnc_us_5799259fe4bo2d5d5ed42db6. Accessed July 29, 2016.

Grimes, Bill. "Political Attack Ads: Lessons Learned.” Jury Expert, November 2010.

Halper, Daniel. "Clinton Campaign's Move to Force Trump Super-PAC Ad Off TV," New York Post, July 27, 2016. http://nypost.com/2016/07/27/clinton-campaigns-move-to-force-trumpsuper-pac-ad-off-tv/.

Hanley, Jason J. “'The Land of Rape and Honey': The Use of World War II Propaganda in the Music Videos of Ministry and Laibach." American Music 22, no. 1 (2004): 158-75.

Hart, Roderick P. Seducing America: How Television Charms the Modern Voter. New York: Oxford University Press, 1994.

Hilton, Paris. "Paris Hilton Blastin McCain." YouTube. http://www.youtube.com/ watch?v=khE6vimLoq4.

Huron, David. "Music in Advertising: An Analytic Paradigm." The Musical Quarterly 73, no. 4 (1989): 557-74.

- - Sweet Anticipation: Music and the Psychology of Expectation. Cambridge, MA: MIT Press, 2006.

Institute for American Democracy and Election Integrity, The. http://trustvote.org. Last update, July 19, 2016. Accessed July 29, 2016.

Iyengar, Shanto and Donald R. Kinder. News that Matters: Television and American Public Opinion . Chicago: University of Chicago Press, 1987.

Jackson, Brooks. “The 'Willie Horton Ad' of 2004?" FactCheck.org, September 28, 2004, www. factcheck.org/2004/o9/the-willie-horton-ad-of-2004. Accessed August 31, 2016.

Jamieson, Kathleen Hall. Electing the President, 2004: The Insider's View. Philadelphia: Univ. of Pennsylvania Press, 2006.

_- Everything You Think You Know About Politics ... and Why You're Wrong. New York: Basic, 2000.

Jhally, Sut. The Codes of Advertising: Fetishism and the Political Economy of Meaning in the Consumer Society. New York: Routledge, 1990.

Johnston, Anne, and Lynda Lee Kaid. "Image Ads and Issue Ads in U.S. Presidential Advertising: Using Videostyle to Explore Stylistic Differences in Televised Political Ads From $195^{2}$ to 2000." Journal of Communication 52, no. 2 (2002): 281-300.

Jowett, Garth, and Victoria O'Donnell. Propaganda and Persuasion. $4^{\text {th }}$ edition. Thousand Oaks, CA: Sage, 2006. 
Kaid, Lynda Lee, Juliana Fernandes, and David Painter. "Effects of Political Advertising in the 2008 Presidential Campaign." American Behavioral Scientist 55, no. 4 (2011): 437-56.

Kaid, Lynda Lee. "Videostyle in the 2004 Presidential Advertising." In The 2004 Presidential Campaign, edited by Robert E. Denton, Jr., 283-99. Lanham, MD: Rowman and Littlefield, 2005 .

Karlin, Fred, and Rayburn Wright, On the Track: A Guide to Contemporary Film Scoring (New York: MacMillan, 1990).

Kaylor, Brian. "A Burkean Poetic Frames Analysis of the 2004 Presidential Ads." Communication Quarterly 56, no. 2 (2008): 168-83.

Kern, Montague. 3o-Second Politics: Political Advertising in the Eighties. New York: Praeger, 1989.

Killmeier, Matthew, and Paul Christiansen. "Wolves at the Door: Musical Persuasion in a 2004 Bush-Cheney Campaign Ad." MedieKultur:Journal of Media and Communication Research 50 (2011): 157-77.

King, Amy, and Andrew Leigh. "Beautiful Politicians." Kyklos 62, no. 4 (2009): 579-93.

Klein, Naomi. No Logo: Taking Aim at the Brand Bullies; No Space, No Choice, No Jobs. New York: Picador USA, 1999.

Koten, John. "Coca-Cola Turns to Pavlov." Wall Street Journal, January 19, 1984, p. 34.

Krasno, Jonathan S., and Donald P. Green. “Do Televised Presidential Ads Increase Voter Turnout? Evidence from a Natural Experiment.” The Journal of Politics 70, no. o1 (2008).

Kristeva, Julia. The Powers of Horror: An Essay on Abjection. Translated by Leon S.Roudiez. New York: Columbia University Press, 1982.

Krumhansl, Carol L. "An Exploratory Study of Musical Emotions and Psychophysiology." Canadian Journal of Experimental Psychology 51 (1997): 336-52.

Kurtz, Bruce D., and Elbert Budin. Spots: The Popular Art of American Television Commercials. New York: Arts Communications, 1977.

Lacan, Jacques. The Seminar of Jacques Lacan: Book II: The Ego in Freud's Theory and in the Technique of Psychoanalysis 1954-1955. New York: W. W. Norton \& Company, 1991.

Lakoff, George, and Mark Johnson. Metaphors We Live By. Chicago: University of Chicago Press, 1980.

Lakoff, George. Don't Think of an Elephant!: Know Your Values and Frame the Debate: The Essential Guide for Progressives. White River Junction, VT: Chelsea Green Pub., 2004.

Lalwani, Ashok, May Lwin, and Pee Beng Ling. "Does Audiovisual Congruency in Advertisements Increase Persuasion? The Role of Cultural Music and Products." Journal of Global Marketing 22, no. 2 (2009): 139-53.

Logan, Robert K. Understanding New Media: Extending Marshall McLuhan. New York: Peter Lang, 2010.

Mann, Robert. Daisy Petals and Mushroom Clouds:LBJ, Barry Goldwater, and the Ad That Changed American Politics. Baton Rouge: Louisiana State University Press, 2011.

Marcus, George E., W. Russell. Neuman, and Michael MacKuen. Affective Intelligence and Political Judgment. Chicago: University of Chicago Press, 2000.

Mark, David. Going Dirty: The Art of Negative Campaigning. Lanham, MD: Rowman \& Littlefield Publishers, 2006.

McClure, John. "Tone of Voice and the Expression of Religious Desire," Otherwise Thinking blog post, October 25, $2011<$ http://johnsmcclure.com/tag/geno-song/>. Accessed August 31, 2016.

McCracken, Allison. "Scary Women and Scarred Men: Suspense, Gender Trouble, and Postwar Change, 1942-1950." In Radio Reader, edited by Michele Hilmes and Jason Loviglio, 183-207. New York: Routledge, 2002. 
McDermott, Rose. "Cognitive Neuroscience and Politics." In The Affect Effect: Dynamics of Emotion in Political Thinking and Behavior, edited by W. Russell Neuman, George E. Marcus, Ann N. Crigler, and Michael MacKuen, 375-98. Chicago: University of Chicago Press, 2007.

McDowell, Charles. Campaign Fever. New York: William Morrow, 1965.

McIlwain, Charlton D., and Stephen M. Caliendo. Race Appeal: How Candidates Invoke Race in U.S. Political Campaigns. Philadelphia: Temple University Press, 2011.

McKinney, Mitchell S., Lynda Lee Kaid, Dianne G. Bystrom, and Diana B. Carlin, eds. Communicating Politics. New York: Lang, 2005.

Meirick, Patrick C., and Gwendelyn S. Nisbett. "I Approve This Message: Effects of Sponsorship, Ad Tone, and Reactance in 2008 Presidential Advertising." Mass Communication and Society 14, no. 5 (2011): 666-89.

Meirick, Patrick C., Gwendelyn S. Nisbett, Matthew D. Jefferson, and Michael W. Pfau. "The Influence of Tone, Target, and Issue Ownership on Political Advertising Effects in Primary Versus General Elections." Journal of Political Marketing 10, no. 3 (2011): 275-96.

Mera, Miguel. “Is Funny Music Funny?” Journal of Popular Music Studies 14/2 (2002): 91-113.

Meyers, Cynthia B. "Measuring Audience Emotions, Past and Present," A Word from Our Sponsor (blog), https://awordfromoursponsor.wordpress.com/author/cynthiameyers, April 28, 2013. Accessed August 20, 2016.

Miller, Mark Crispin. Fooled Again: How the Right Stole the 2004 Election and Why They'll Steal the Next One Too (Unless We Stop Them). New York: Basic, 2005.

Montgomery, Dave. "Experts Say Fear-mongering Making This the Ugliest Election in Memory." Fort Worth Star-Telegram, October 29, 2004.

Müllensiefen, Daniel. "Sensum - Goldsmiths Study on the Effectiveness of Music in Advertising," https://www.youtube.com/watch?v=TzZsUMdBQQQ, March 7, 2014. Accessed July 9, 2016.

Nelson, John S., and George R. Boynton. Video Rhetorics: Televised Advertising in American Politics. Urbana: University of Illinois Press, 1997.

Neuman, W. Russell, George E. Marcus, Ann N. Crigler, and Michael MacKuen, eds. The Affect Effect:Dynamics of Emotion in Political Thinking and Behavior. Chicago: University of Chicago Press, 2007.

Noggle, Gary, and Lynda Lee Kaid. "The Effects of Visual Images in Political Ads: Experimental Testing of Distortions and Visual Literacy." Social Science Quarterly 81, no. 4 (2000): 913-27.

Oettinger, Rebecca Wagner. Music as Propaganda in the German Reformation. Aldershot, UK: Ashgate, 2001.

Packard, Vance. The Hidden Persuaders. Originally published in 1957. New York: Pocket Books, $195^{8 .}$

Page, Susan. "Friday News Roundup_Domestic," The Diane Rehm Show, [Susan Page filling in for Rehm], January 22, 2016, http://thedianerehmshow.org/shows/2016-01-22/friday-newsroundup-domestic. Accessed August 18, 2016.

Parti, Tarini. “\$7 billion spent on 2012 campaign, FEC says," Politico < http://www.politico.com/ story/2013/01/7-billion-spent-on-2012-campaign-fec-says-87051.html >. Accessed August $31,2016$.

Patterson, Jim. “Campaign Aims to Take Stigma Off Country Music," Pittsburgh Post-Gazette, May 10, 2001, p. B19.

Perris, Arnold. Music as Propaganda: Art to Persuade, Art to Control. Westport, CT: Greenwood, 1985 .

Peterson, Steven A. Political Behavior: Patterns in Everyday Life. Newbury Park, CA: Sage, 1990.

Potter, Pamela M. Most German of the Arts: Musicology and Society from the Weimar Republic to the End of Hitler's Reich. New Haven, CT: Yale Univ. Press, 1998. 
Pratkanis, Anthony R., and Elliot Aronson. Age of Propaganda: The Everyday Use and Abuse of Persuasion. New York: W.H. Freeman, 2002.

Press, Bill. “John McCain Plays the Race Card," Huffington Post, July 31, 2008 <http://www. huffingtonpost.com/bill-press/john-mccain-plays-the-rac_b_116042.html>. Accessed December 31, 2015 .

Ragas, Matthew, and Spiro Kiousis. "Intermedia Agenda-Setting and Political Activism: MoveOn. org and the 2008 Presidential Election." Mass Communication and Society 13, no. 5 (2010): $560-83$.

Respaut, Robin and Lucas Iberico Lozada. "Digital Strategy Firms Could See Tripling of Political Ads," Las Vegas Review Journal, April 14, 2015 <http://www.reviewjournal.com/business/ retail/digital-strategy-firms-could-see-tripling-political-ads $>$. Accessed August 31, 2016.

Richardson, Glenn W. Pulp Politics: How Political Advertising Tells the Stories of American Politics. Lanham, MD: Rowman \& Littlefield, 2003.

Ridout, Travis N., and Michael M. Franz. The Persuasive Power of Campaign Advertising. Philadelphia: Temple University Press, 2011.

Rikard, Dorlea. "Patriotism, Propaganda, Parody, and Protest: The Music of Three American Wars." Literature \& the Arts: An International Journal of the Humanities 16, no. 1-2 (2004): 129-44.

Robinson, Jenefer. Deeper than Reason: Emotion and Its Role in Literature, Music, and Art. Oxford: Clarendon Press, 2005.

Rodman, Ronald W. "Music in Political Ads." OUPblog. November 20, 2012. Accessed July 25, 2013. http://blog.oup.com/2012/11/music-in-political-ads/.

- - Tuning In: American Narrative Television Music. Oxford: Oxford University Press, 2010.

Roseboom, Eugene H. and Alfred E. Eckes, A History of Presidential Elections: From George Washington to Jimmy Carter, $4^{\text {th }}$ ed. New York: Macmillan, 1979.

Ross, Alex. Listen to This, $3^{\text {rd }}$ ed. New York: FSG, 2010.

Rousseau, Jean-Jacques. Two Essays on the Origin of Language, as quoted in Emily Dolan, The Orchestral Revolution: Haydn and the Technologies of Timbre. Cambridge, UK: Cambridge University Press, 2013.

Rutherford, John. “Nixon Tapes: Ruthless, Cynical, Profane," NBC News (December 2, 2008). http:/firstread.nbcnews.com/_news/2008/12/02/4429073-nixon-tapes-ruthless-cynicalprofane?lite. Accessed August 31, 2016.

Said, Edward. Orientalism. New York: Pantheon Books, 1978.

Sainato, Michael. "Debbie Wasserman Schultz Served Class Action Lawsuit for Rigging Primaries," Observer, http://observer.com/2016/o6/debbie-wasserman-schultz-served-class-actionlawsuit-for-rigging-primaries/, June 30, 2016. Accessed July 29, 2016.

Saussure, Ferdinand de. Course in GeneralLinguistics. Reprint from 1916. New York: Philosophical Library, 1959.

Schaller, Michael. Right Turn: American Life in the Reagan-Bush Era, 1980-1992. Oxford: Oxford University Press, 2007.

Schlesinger, Arthur M., ed. The Coming to Power: Critical Presidential Elections in American History. New York: Chelsea House, 1981.

Schoening, Benjamin S., and Eric T. Kasper. Don't Stop Thinking about the Music: The Politics of Songs and Musicians in Presidential Campaigns. Lanham, MD: Lexington Books, 2012.

Schwartz, Tony. The Responsive Chord:How Media Manipulate You-Whatyou Buy, Who You Vote For, and How You Think. $2^{\text {nd }}$ edition. Original published in 1973. Coral Gables, FL: Mango, 2017. Seymour Ben and Ray Dolan. "Emotion, Decision Making, and the Amygdala," Neuron 58 (2008): 662-71. 
Shea, Andrea. “Campaign Ad Music: It's All About Emotional Response." Transcript from All Things Considered segment on WBUR. October 26, 2012. Accessed July 31, 2013. http://www. wbur.org/2012/10/26/campaign-ad-music.

Shen, Fuyuan, Frank E. Dardis, and Heidi Hatfield Edwards. "Advertising Exposure and Message Type: Exploring the Perceived Effects of Soft-Money Television Political Ads." Journal of Political Marketing 10, no. 3 (2011): 215-29.

Sheppard, W. Anthony. “An Exotic Enemy: Anti-Japanese Musical Propaganda in World War II Hollywood." Journal of the American Musicological Society 54, no. 2 (2001): 303-57.

Silverman, Kaja. The Acoustic Mirror: The Female Voice in Psychoanalysis and Cinema. Bloomington, IN: Indiana University Press, 1988.

Sproule, J. Michael. Channels of Propaganda. Bloomington, IN: ERIC, 1994.

Stanley, Timothy. Kennedy vs. Carter: The 1980 Battle for the Democratic Party's Soul. Lawrence, KS: University Press of Kansas, 2010.

Stilwell, Robynn J. Composing for the Screen in Germany and the USSR: Cultural Politics and Propaganda. Bloomington, IN: Indiana University Press, 2008.

Stein, Sam and Paul Blumenthal. "Obama 2012 Campaign Spending Buried Romney On Airwaves and with Staff," Huffington Post, 12 December $2012<$ http://www.huffingtonpost. com/2012/12/12/obama-2012-campaign-spending_n_2287978.html>. Accessed August 31, 2016.

Sullivan, Patricia. "Pioneering GOP Consultant John Deardourff Dies at 61." Washington Post (December 28, 2004). http://www.washingtonpost.com/wp-dyn/articles/A30397-2004Dec27. html. August 31, 2016.

Swift, Will. Pat and Dick: The Nixons, An Intimate Portrait of a Marriage. New York: Simon and Schuster, 2014.

Tagg, Philip. Kojak: Fifty Seconds of Television Music; Toward the Analysis of Affect in Popular Music (orig. pub. 1979). New York: Mass Media Music Scholars' Press, 2000.

Tan, Shzr Ee. "Manufacturing and Consuming Culture: Fakesong in Singapore." Ethnomusicology Forum 14, no. 1 (2005): 83-106.

Taylor, Timothy D. The Sounds of Capitalism: Advertising, Music, and the Conquest of Culture. Chicago: University of Chicago Press, 2012.

Television Plans Board. “A Proposal: Television Campaigning for President Eisenhower," Eisenhower Presidential Library, Abilene, Kansas.

Tellis, Gerard J. Effective Advertising: Understanding When, How, and Why Advertising Works. Thousand Oaks, CA: Sage Publications, 2004.

Thurber, James A., Candice J. Nelson, and David Dulio. Crowded Airwaves: Campaign Advertising in Elections. Washington, DC: Brookings Institution Press, 2000.

Todes, Daniel. Ivan Pavlov: A Russian Life in Science. New York: Oxford University Press, 2014.

Trainor, Laurel J., and Louis A. Schmidt. "Processing Emotions Induced by Music." In The Cognitive Neuroscience of Music, edited by Isabelle Peretz and Robert J. Zatorre, 310-24. Oxford: Oxford University Press, 2003.

“Truck Driver's Gear Change," TV Tropes, http://tvtropes.org/pmwiki/pmwiki.php/Main/ TruckDriversGearChange. Accessed August 29, 2016.

Turner, Graeme. Film as Social Practice. New York: Routledge, 1993.

Volker, Reimar. "Herbert Windt's Film Music to Triumph of the Will: Ersatz Wagner or Incidental Music to the Ultimate Nazi-Gesamtkunstwerk?" In Composing for the Screen in Germany and the USSR : Cultural Politics and Propaganda, edited by Robynn J. Stilwell and Phil Powrie, 39-53. Bloomington, IN: Indiana University Press, 2008. 
Washburn, C. Langhorne. Letter of August 1955 to National Citizens for Eisenhower. Eisenhower Presidential Library. Abilene, Kansas.

Wei, Ran, and Ven-Hwei Lo. "The Third-Person Effects of Political Attack Ads in the 2004 U.S. Presidential Election." Media Psychology 9, no. 2 (2007): 367-88.

West, Darrell M. Air Wars: Television Advertising in Election Campaigns, 1952-2008. Washington, DC: CQ Press, 2010.

"What Trouble? Clinton Has Early Lock On Iowa Caucus, Quinnipiac University Poll Finds; Sanders, Biden Are Only Dems Over 3\%," May 7, 2015, https://www.qu.edu/news-and-events/ quinnipiac-university-poll/iowa/release-detail?ReleaseID=2224. Accessed August 13, 2016. White, Theodore Harold. The Making of The President 1964. New York: Atheneum, 1965.

Williams, Andrew Paul, and John C. Tedesco. The Internet Election. Lanham, MD: Rowman \& Littlefield, 2006.

Williams, Raymond. Marxism and Literature. London: Oxford University Press, 1978.

Wood, B. Dan. The Myth of Presidential Representation. Cambridge, UK: Cambridge University Press, 2009.

Wright, Isaac. "It's More Than Just Putting Ads Online." Politics (Campaigns \& Elections), 2009. Zernike, Kate and Jim Rutenberg. "Friendly Fire: The Birth of an Attack on Kerry," New York Times, August 20, 2004, http://www.nytimes.com/2004/08/20/us/the-2004-campaign-advertisingfriendly-fire-the-birth-of-an-attack-on-kerry.html?_r=o. Accessed August 31, 2016. 


\section{Index}

Note: Page numbers with "n" or "nn" indicate notes.

47 percent comments by Romney, $185,193-94$ The 270 Group, "Kids" (Perot) (1992), 134-35 527 organizations, 2004 campaign influence of, 10

1952 campaign (Eisenhower vs. Stevenson), $31-41$

1956 campaign (Eisenhower vs. Stevenson), $43-46$

1960 campaign (Kennedy vs. Nixon), 47-55 1964 campaign (Johnson vs. Goldwater), 56-62 1968 campaign (Nixon vs. Humphrey), 63-72 "1969" (Gore-Lieberman) (2000), 146-47 1972 campaign (Nixon vs. McGovern), 73-89 1976 campaign (Carter vs. Ford), 9o-94 1980 campaign (Reagan vs. Carter vs.

Anderson), 95-100

1984 campaign (Reagan vs. Mondale), 101-18 "1984" Orwellian ad for Apple Macintosh, 109 1988 campaign (Bush vs. Dukakis), 119-28 1992 campaign (Clinton vs. Bush vs. Perot), 129-37

1996 campaign (Clinton vs. Dole), 138-43 2000 campaign (Bush vs. Gore), 144-50 2004 campaign (Bush vs. Kerry), 151-74 2008 campaign (Obama vs. McCain), 175-84 2012 campaign (Obama vs. Romney), 185-94 2016 campaign (Trump vs. Clinton), 195-211

acousmêtre

"Mother and Child" (Humphrey) (1968), 68

Nixon's voice in "First Civil Right" as, 65

"Nixon the Man" (1972), 85

"Adlai to You" (Stevenson) (1952), 40-41 advertising agencies

Bailey, Deardourff and Associates, 91-92

Batten, Barton, Durstine \& Osborn, 43, 217-18

Della Femina Travisano \& Partners, 104

Doyle Dane Bernbach, 56n1, 57, 58-59

Guild, Bascom and Bonfigli, 54-55

Interpublic: Erwin Wasey, Ruthrauff and Ryan, Inc., 59-62

Maverick Media, $151-67,170-74$

Stevens, Reed, Curcio and Potholm, 169-70

Young and Rubicon, 43-46

advocacy ads

"1969" (Gore) (2000), 146-47

"Commander" (Carter) (1980), 97-98

"Dangerous World" (Bush) (2000), 148-50

"Dr. No" as, $177-78$

maximum effect in 1984, 95

"Nixon Now" (Nixon) (1972), 74-8o
"Peace" (Ford) (1976), 91-92

"Peace" (Reagan) (1980), 96-97

"State" (Carter) (1980), 98-100

"Whatever It Takes" (Bush) (2004), 166-67

"Yes, We Can" (Obama) (2008), 176-77

"Young Vets" (McGovern) (1972), 88-89

See also dual advocacy/attack ads; "Morning in America"

aesthetic object, political ad as, 68-69, 75, 95, $103,117-18$

African American voters, Kennedy's appeal

through Belafonte, $54-55$

Agnew, Spiro, $69 n 9$

Ailes, Roger, 104, 120-22

"America" (Sanders) (2016), 206-11

"America" (song, Simon and Garfunkel), 207-11

"America the Beautiful" (sung by Romney), 188

amygdala, role in emotional response process-

ing, 14-15, 16n17

Anderson, John, 96

Anzieu, Didier, 18

Aristotle, 31

Ars Rhetorica (Aristotle), 31

Aslan, Mubeen, 142

atmospheric ads, 74-80, 104n6, 110-12, 207-11.

See also "Morning in America" attack ads

"Barbershop" (Clinton) (2012), 196

"Big Bird" (Obama) (2012), 191-92

"Celeb" (McCain) (2008), 178-80

"Convention" (Nixon) (1968), 26, 70-72

"Daisy" (Clinton) (2012), 196

"Daisy" (Johnson) (1964), 56, 61-62, 140, 196

"Desperate" (Clinton) (1996), 138

"Dr. No" (McCain) (2008), 177-78

"Drums" (Clinton) (1996), 141-42

"Embrace" (Obama) (2008), 181-82

"Failure 3" (Mondale) (1984), 116-18

"Finish It" (Bush) (2004), 167-69

"Firms" (Obama) (2012), 186, 187-89

"The First Civil Right" (Nixon) (1968), 64-65

"Fundamentals" (Obama) (2008), 180-81

"Furlough from the Truth" (Dukakis) (1988), $125^{-26}$

"Guess" (Bush) (1992), 131-34

"Health Care" (Bush) (1992), 130-31

"Limo" (Mondale) (1984), 113-14

"Loopholes" (Mondale) (1984), 115

"Maine" (Clinton) (1992), 135-37

"Mandatory" (Obama) (2012), 189-9o

"McGovern Defense" (Nixon) (1972), 26, $87-88,117$ 
“Mirrors" (Clinton) (2012), 196

"Morning in America" as subtle example of, 105

"Morph" (Gore) (2000), 147-48

"My Job" (Obama) (2012), 193-94

"No Maverick" (Obama) (2008), 182-84

"Outsourcing" (Trump) (2016), 195-98

"Oval Office” (Dukakis) (1988), 126

plethora of in 1988, 95, 119

"Political Payoffs and Middle Class Layoffs" (Romney) (2012), 192

"Revolving Door" (Bush) (1988), 105n7, 119, 120-22

"Role Models" (Clinton) (2012), 196

"Russia Response" (McGovern) (1972), 83

"Tank Ride" (Bush) (1988), 119, 124-25

"The Threat" (Dole) (1996), 140-41

"Wacky" (Bush) (2004), 170-72

"Wolves" (Bush) (2004), 10-12, 26, 27, 110, 151-65

See also dual advocacy/attack ads; humor in attack ads

Backer, Bill, 74

Bailey, Deardourff and Associates, 91-92

Baker, Bobby, 59

Ball, Philip, 106

"Barbershop" (Clinton-Kaine) (2012), 196

Barone, Brian, 209

Barthes, Roland, 108, 159

Batten, Barton, Durstine \& Osborn (BBDO), 43, $217-18$

Belafonte, Harry, 54-55

Berlin, Irving, 45

Bernie 2016, “America," 206-11

Berry, Chuck, 208

Bharara, Preet, 202

"Big Bird" (Obama) (2012), 190-92

Binet, Les, 214

Bipartisan Campaign Reform Act of 2002, 211

The Blue Danube (Strauss), 19, 173

bluegrass music, 190

blues music (1930s), 58-59

"Bomb" (Humphrey-Muskie) (1968), 69

Brader, Ted, 15

Bradshaw, Sally, 216

brain response to sound and image, $14-15$, 16n17, 214-15

Brexit, 204-5

Brown, Jerry, 95-96

Bush, George H. W., 105, 119, 135-36. See also

Clinton vs. Bush vs. Perot

Bush, George W., 10, 144, 175, 182-84

Bush, Jeb, 198

Bush-Cheney '04, Inc., 151-74

Bush-Quayle '88, 119-22

Bush-Quayle '92 General Committee, Inc., 130-34

Bush vs. Dukakis (1988), 119-28
Ailes as consultant for Bush, 105

"Counterpunch" (Dukakis), 127-28

"Furlough from the Truth" (Dukakis), $125^{-26}$

"Harbor" (Bush), 119, 123

"Oval Office" (Dukakis), 126

"Revolving Door" (Bush), 105n7, 119, 120-22

"Tank Ride" (Bush), 119, 124-25

"Willie Horton," 119, 120

Bush vs. Gore (2000), 144-50

"1969" (Gore), 146-47

"Dangerous World" (Bush), 148-50

"Down" (Gore), 146

"Education Recession" (Bush), 145

"Morph" (Gore), 147-48

Bush vs. Kerry (2004), 151-74

effectiveness of Bush's ads, 10, 27-28

"Finish It" (Bush), 167-69

"Sellout" (Swift Boat), 169-70

"Wacky" (Bush), 170-72

"Whatever It Takes" (Bush), 166-67

"Windsurfing" (Bush), 19, 172-74

"Wolves" (Bush), 10-12, 26, 27, 110, 151-65

"buy-outs" of campaign music, 97n3

Caddell, Patrick, 94

calypso music, in Kennedy ad, 54-55

The Campaign Company (for Gore 2000), 146-48

Campaigning for Hearts and Minds (Brader), 24

Campbell, Tracy, 206

Carroll, Noel, 160

Carter, Jimmy, 9o, 95-96

Carter/Mondale Re-Election Committee (1980), 97-100

Carter vs. Ford (1976), 90-94

"Peace" (Ford), 91-92

"South" (Carter), 92-94

"Cartoon Guy" (Eisenhower) (1956), 45-46

Carville, James, 129

Castellanos, Alex, 17, 159nn17-18, 163, 164

"Celeb" (McCain) (2008), 178-80

chaos, music as metaphor for, 64

character ads

"1969" (Gore) (2000), 146-47

"Mother and Child" (Humphrey) (1968), 65-69

"Windsurfing" (Bush) (2004), 19, 172-74

Chion, Michael, 68

choral music

"Adlai to You" (Stevenson) (1952), 40-41

"I Like Ike" (1952), 32-38

"My Job" (Obama) (2012), 193-94

"Nixon Now" (Nixon) (1972), 77-78

"Peace" (Ford) (1976), 91-92

Citizens for Eisenhower, 32-38, 43-46

Citizens for Humphrey-Muskie, 69

Citizens for Kennedy-Johnson (1960), 47-54

Civil Rights Act of 1964, 59 
Clarke, Jeremiah, 85

classical familiar music in political ads, 19, 81, 173

"Classroom" (Dole-Kemp) (1996), 141

Clinton, Bill, 129, 132, 138

Clinton, Hillary, 176, 195-96, 198-206. See also Trump vs. Clinton

Clinton-Gore ' 92 Committee, 134-37

Clinton-Gore ' 96 General Committee, "Surgeon," 142-43

Clinton-Gore Creative Team, 134

Clinton vs. Bush vs. Perot (1992), 129-37

"Guess" (Bush), 131-34

"Health Care" (Bush), 130-31

"Kids" (Perot), 134-35

"Maine" (Clinton), 135-37

"Scary" (Clinton), 134

Clinton vs. Dole (1996), 138-43

"Classroom" (Dole), 141

"Drums" (Clinton), 141-42

"Stripes" (Dole), 139-40

"Surgeon" (Clinton), 142-43

"The Threat" (Dole), 140-41

Clinton vs. Sanders (2016), 198-211

"America" (Sanders), 207-11

"It's a Revolution" (Sanders), 207n22, 211

coal miners ad (Obama 2012), 189-9o

Coca-cola and "Hilltop song" ad, 74

Cochran, Jacqueline, 32-34

"Cognitive Neuroscience and Politics"

(McDermott), 217

Cold Harbor Films, "Education Recession" (Bush) (2000), 145

Cole, Jim, 117n22, 222-40

Comey, James, 202-3

"Commander" (Carter-Mondale) (1980), 97-98

commercial product ads, modeling political ads on, $31,75-76,92,217-18$

Committee to Re-Elect the President (1972), $74-87$

communal aspect in music through choral method, $37-38,77$

conditioning effect of political advertising, $14-16,214-15$

Confederate flag evocation in Kennedy ad, $5^{1-52,} 5^{2 n 6}$

Consultants '84, "Limo" (Mondale), 113-14

contemporary art music composed for orchestra, Nixon vs. Humphrey (1968), 63 contrast ads

"Drums" (Clinton) (1996), 141-42

"Loopholes" (Mondale) (1984), 115

"Mother and Child" (Humphrey) (1968), $65^{-69}$

"Surgeon" (Clinton) (1996), 142-43

"Who We Are" (Clinton) (2012), 196

"Windsurfing" (Bush) (2004), 19, 172-74

"Convention" (Nixon-Agnew) (1968), 26, 70-72

Cook, Nicholas, 108, 159
Copland, Aaron, 115

Corker, Bob, 179

“Counterpunch" (Dukakis-Bentsen) (1988), $127-28$

country music, 132-33, 148, 196, 213

creative agencies. See advertising agencies

critical thinking education to analyze political ads, $220-21$

cultural artifacts of political ads, 18-19, 159, 176

Cuomo, Chris, 199

Daily, Peter, 73

"Daisy" (Clinton) (2012), 196

"Daisy" (Johnson) (1964), 56, 61-62, 140, 196

Daisy Petals and Mushroom Clouds (Mann), 61

Dallek, Matthew, 215-16

“Dangerous World" (Bush-Cheney) (200o), $148-50$

Davis, Billy, 74-80

Davis, George, 45, 52

Deardourff, John, 94

Deaville, James, 213-14

Della Femina, Jerry, 104

Delta blues guitar music (1930s), "Poverty" (Johnson) (1964), 58-59

\#DemExit (2016), 204-6

democracy corrosive effect of ad music on, 216 and Democratic Party's handling of Clinton vs. Sanders, 204

music in political ads and value of, $205^{-6}$ virtue or vice of negative ads in, 17

Democratic National Committee Belafonte ad (Kennedy) 1960, 54-55

"Poverty" (Johnson) (1964), 58-59

Sanders voters' lawsuit against, 203

"Voting Booth" (Johnson) (1964), 57-58

Democratic Party

challenges of 1980 for, 96,99

handling of Clinton vs. Sanders, 198-206

as most compassionate toward women and vulnerable groups, 68

protests and violence at 1968 convention, 70 reluctance to embrace music in political ads, 127

reluctance to embrace TV ads, 45

Democratic Presidential Campaign Committee, Inc., 92-94

Democrats for Nixon, $87-88$

“Deplorables" (Trump) (2016), 195

"Desperate" (Clinton-Gore) (1996), 138

diegetic music, 65-66, 84-87, 99, 106

disclaimer on political ad, 211

Disney, Roy (Oliver), 32-38

dissonant music, 11, 12, 27, 63, 64-65

distortion of music, Nixon 1968 campaign's introduction of, 71

Dole, Bob, 138. See also Clinton vs. Dole

Dole-Kemp '96, 139-41 
Don't Stop Thinking About the Music (Schoening and Kasper), 26-27

"Down" (Gore-Lieberman) (2000), 146

Doyle Dane Bernbach, 56n1, 57, 58-59

"Dr. No" (McCain) (2008), 177-78

"The Draft Horse" (Warner Brothers cartoon song), 140

drum effects

"Bomb" (Humphrey) (1968), 69

"Failure 3" (Mondale) (1984), 117

"Health Care" (Bush) (1992), 130

as heartbeat, 111, 112

"McGovern Defense" (Nixon) (1972), 87-88

"Wolves" (Bush) (2004), 161, 162

"Drums" (Clinton-Gore) (1996), 141-42

dual advocacy/attack ads

"Down" (Gore) (2000), 146

"Drums" (Clinton) (1996), 141-42

"Education Recession" (Bush) (2000), 145

"Surgeon" (Clinton) (1996), 142-43

Dubow, Joel S., 14

Dukakis, Michael, 119, 127. See also Bush vs. Dukakis

Dukakis-Bentsen Comm, Inc. (1988), 125-28

Dunning Kruger Effect, 19

Dusenberry, Phil, 104, 105

Dylan, Jesse, $176-77$

Eagleton, Thomas, 83

Eckes, Alfred E., Jr., 94

"Education Recession" (Bush-Cheney) (2000), 145

Eisenhower, Dwight D., 42, 50, 217-18

Eisenhower vs. Stevenson (1952), 31-41

"Adlai to You" (Stevenson), 40-41

"I Like Ike" (Eisenhower), $32-38$

"I Love the Gov"” (Stevenson), 38-40

Eisenhower vs. Stevenson (1956), "Taxi Drive and Dog" (Eisenhower), 43-46

election fraud, 199, 200-201, 203

election integrity, $205^{-6}$

"An Electoral System in Crisis" (Fries'dat,

Sampietro, and Scheuren), 203

electronic media impact vs. print media, 215

electronic music for emotional impact in

"Wolves," 152-53, 165

Eliot, Marc, 207

elitism and Stevenson's “Adlai to You" (1952), $40-41$

"Embrace" (Obama) (2008), 181-82

emotional appeal of music in political ads anti-immigration message through

Orientalist music, 141

with atmospheric ads, 101-9, 208, 211

and bypassing of rhetorical scrutiny, 153

in character advocacy ad, 74-80

for commercial ads, 214

contradiction with sound effects, $148-5^{0}$

critical thinking education to analyze,

220-21 effectiveness vs. rational appeal, 17, 71, 83

forlorn or mournful sound for negative

effect, $169,190,196$

generating anger for negative effect, 123

gravity of situation vs. child's play superficiality, $87-88$

to highlight contrasts, 214

humanizing of enemy with, 81

humor used to ridicule opponent, 136

importance in persuasion, $216-17$

and ineffability of music, 20-21

matching music to spoken cadence, $166-67$

minor keys for negative effect, 113-14, 193-94

more intentional use of in 196os, $5^{6}$

music's power to create emotional impact,

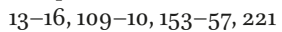

scholarly lack of attention to, 218-19

through key modulations, 106-7, 147

timbre of music, $139 \mathrm{n} 1$

use of heartbeat with music, 126

See also fear-based messages

enthymemes

"Morning in America" (Reagan) (1984), 105

"Russian Bear" (Reagan) (1984), 111

"Wolves" (Bush) (2004), 163-64

Estes, Billie Sol, 6o

ethos (endorsement by authority), appeal to, 31 exit polling and election fraud (2016), 200-201 exposure element in success of emotional appeal political ads, $16 \mathrm{n} 16$

"The Facts" (Clinton-Gore) (1996), 138-39

factual basis, negative ads debate, $17-18$

"Failure 3" (Mondale-Ferraro) (1984), 116-18

fear-based messages

commander-in-chief capability worries, $56-62,116-18,119,167-69$

economic problems, 146

health care worries, $130-31$

"heartbeat from the presidency" fears about vice presidential candidates, 126

law and order worries, $26,60,64-65$, $120-22,141$

nuclear war threat, $61-62,69$

as political ad category for maximum emotion-to-action impact, $15^{-16}$

role in persuading action by voters, 11-12, $15^{-16,26}$

security and national defense worries, $11-12,66-68,70-72,87-88,110-12$, $148-50,151-65$

as sensationalism and propaganda, 17

See also horror film music

Feltus, William J., 215-16

fight-or-flight response, eliciting in political ads, 15

"Finish It" (Bush-Cheney) (2004), 167-69

"Firms" (Obama) (2012), 186, 187-89 
"The First Civil Right" (Nixon-Agnew) (1968), $26,64-65$

folk music, 53, 80, 81, 207-11

Fonda, Henry, 53-54

Ford, Gerald R., 9o. See also Carter vs. Ford foreboding music

association with candidate most desperate to win, 138

"The Threat" (Dole) (1996), 141

"Wolves" (Bush) (2004), 158

"Foreign Policy" (Reagan-Bush) (1984), 110

Foxhole Productions (McCain 2008), 177-80

Frank, Thomas, 76, 205

Frankenberry, Dennis, 119, 120-22

Franz, Michael M., 22

Freymann-Weyr, Jeffrey, 214

Fries'dat, lulu, 203

"Fundamentals" (Obama) (2008), 180-81

"Furlough from the Truth" (Dukakis-Bentsen) (1988), 125-26

Garment, Leonard, 64-65, 70-72

Geer, John G., 17

gender, and female voice-over, 11, 130-31, $15^{8-59}$

"geno-song," 108-9n15

genre, music as signifier of, $170-72$

George, Gil, 34

Gerber, Alan S., 22

Gilens, Martin, 204

"The Girl I Left Behind", 52-53

"God Bless the USA" (Greenwood), 127

Goldstein, Kenneth M., 215-16

Goldwater, Barry, 56. See also Johnson vs. Goldwater

Gorbman, Claudia, 112

Gore, Al, 144. See also Bush vs. Gore

Gore-Lieberman, Inc. (2000), 146-48

Green, Al, 192

Green, Donald P., 22

Greenwood, Lee, 127

“Guess" (Bush-Quayle) (1992), 131-34

Guggenheim, Charles, 88-89

Guild, Bascom and Bonfigli, 54-55

guitar music, 80, 81, 93, 170, 176-77, 207-11

"Hail to the Chief" as musical allusion, $5^{2}, 88$, 96-97

Halloween theme, 113, 114

"Harbor" (Bush-Quayle) (1988), 119, 123

harmonic shift for dramatic effect, 106, 143

Hart, Roderick P., 19-20, 23-24

"Health Care" (Bush-Quayle) (1992), 130-31

The Hidden Persuaders (Packard), 52, 217

"Hilltop song," 74-79

horror film music

"Dangerous World" (Bush) (2000), 148-50

"Health Care" (Bush) (1992), 131

"Limo" (Mondale) (1984), 113-14
"Revolving Door" (1988), 121-22

"Wolves" (Bush) (2004), 151-65

Horton, William, 120

"Hot Time in the Old Town Tonight," 57, 71

humor in attack ads

"Big Bird" (Obama) (2012), 191-92

"Firms" (Obama) (2012), 186

Nixon's flipping technique in ad against McGovern, $172-73 n 7$

"No Maverick" (Obama) (2008), 183

"Tank Ride" (Bush) (1988), 119, 124-25

"Wacky" (Bush) (2004), 170-72

"Windsurfing" (Bush) (2004), 172-74

Humphrey, Hubert, 73. See also Nixon vs.

Humphrey

Humphrey-Muskie (1968), 65-69

identity politics ads, 196

"I'd Like to Buy the World a Coke," 74

"I Like Ike" ("Ike for President") (1952), 32-38

"I Love the Gov'” (Stevenson) (1952), 38-40

"Inflation" (Reagan-Bush) (1984), 110

Inside Campaigns (Feltus, Goldstein, and

Dallek), $215^{-16}$

Interpublic: Erwin Wasey, Ruthrauff and Ryan, Inc., 59-62

Iran hostage crisis, 99-100

Irish folksong, musical allusion in Kennedy ad, 53

"I Still Like Ike" (Berlin), 45

"It's a Revolution" (Sanders) (2016), 207n22, 211

James Bond theme in "Dr. No" ad, 178

Jamieson, Kathleen Hall, 17-18

jazz music, $38,39-40,181-82$

jingles in mid-century ads, $32-38,47-53$

John McCain 2008, 177-80

"Johnny B. Goode" (Berry), 208

Johnson, Lyndon B., 56, 70, 71

Johnson vs. Goldwater (1964), 56-62

"Morality" (Goldwater), 59-62

"Poverty" (Johnson), 58-59

"Voting Booth" (Johnson), 57-58

Johnston, Anne, 219

Jones, Eugene, $64-65,70-72$

Kaid, Lynda Lee, 219

Kasper, Eric T., 26-27

Kennedy, John F., 42, 48, 53-54

Kennedy, Ted, 95, 96

"Kennedy: Jingle" (1960), 47-53

Kennedy vs. Nixon (1960), 47-55

Belafonte ad, $54-55$

Fonda ad, 53-54

"Kennedy: Jingle," 47-53

Kerry, John, 10, 19, 27, 151. See also Bush vs. Kerry

key modulations

“1969" (Gore) (2000), 146-47 
for energy and momentum, 37

"Morning in America" (Reagan) (1984), $106-7,147$

"Nixon Now" (Nixon) (1972), 78

"Surgeon" (Clinton-Gore) (1996), 142-43

Khomeini, Ruhollah, 99-100

“Kids" (Perot) (1992), 134-35

King, Angus, 139n1

Kristeva, Julia, 123

Krumhansl, Carol, 15-16

Lacan, Jacques, 123

LaFontaine, Don, 191

late-night talk show music, as trivializing technique for attack ad, 182

"Laura" (Trump) (2016), 195-96

LeDoux, Joseph, 15

"Let's Stay Together" (Green), 192

Levinson, Barry, 212

Lewinsky, Monica, 144

“Liberty Park/Hope Campaign 8o" (Reagan) (1980), 97

"Limo" (Mondale-Ferraro) (1984), 113-14

logos (reason), appeal to, in 1950s ads, 31. See also rational vs. emotional motives for action

“Loopholes" (Mondale-Ferraro) (1984), 115 lullaby, $67-69$

"Maine" (Clinton-Gore) (1992), 135-37

"Mainers Know" (U.S. Chamber of Commerce), 139n1

major keys

"Dangerous World" (Bush) (200o), 148

"Education Recession" (Bush) (2000), 145

"Finish It" (Bush) (2004), 168

"Kennedy-Jingle" (Kennedy) (1960), 50

"Yes, We Can" (Obama) (2008), 176-77

major/minor key changes for contrast ads, $142-43,166-67$

"Mandatory" (Obama) (2012), 189-9o

mandolin in "Mandatory" for location and culture setting, 190

Mann, Robert, 61

"Mark Oz Geist" (Trump) (2016), 195-96

martial music

for commander in chief credentials, 97-98, 112

foreign policy leadership, 57-58, 98-100

and "joining in" energy of "I Like Ike," 37, 40

military service allusions, 53-54, 140

Maverick Media (Bush 2004)

"Wacky," 170-72

"Whatever It Takes," 166-67

"Windsurfing," 172-74

"Wolves," 10-12, 26, 27, 110, 151-65

McCain, John, 175, 185-86. See also Obama vs. McCain

McCain 2008, 177-80
McClure, John, 108-9n15

McDermott, Rose, 217

McGovern, George, 73, 74, 86. See also Nixon vs. McGovern

McGovern 1972, 83, 88-89

"McGovern Defense" (Democrats for Nixon) (1972), 26, 87-88, 117

media support for Clinton (2016), 199-200, 201, 204

Mendelssohn, Felix, 21

Messner, Tom, 104

metadiscursive function of music, $84,173^{-74}$

metaphors as condensers of emotional impact, 159,160

Meyers, Cynthia B., 18, 217

military music. See martial music

Miller, Scott, 126-28

minor keys

"Big Bird" (Obama) (2012), 191-92

eliciting fear with, 11

"Fundamentals" (Obama) (2008), 180-81

"My Job" (Obama) (2012), 193

and negative business as usual, 114

"Mirrors" (Clinton) (2012), 196

Mokal Music, 213-14

Mondale/Ferraro Committee, Inc, 105, 112, $113-18$

"Morality" (Goldwater) (1964), 59-62

"Morning in America" (Reagan-Bush) (1984)

compared to Sanders's "America," 208

impact of music in, 101-9

influence of, $117-18$

key modulations in, 106-7, 147

and lack of scholarly attention to music's impact, 26,27

"Nixon Now" as precursor of, 75

in overview of campaign, 95

"Morph" (Gore-Lieberman) (2000), 147-48

Morricone, Ennio, 182

"Mother and Child" (Humphrey-Muskie) (1968), 65-69

mournful music, as context for negative ads, 169,196190

Müllensiefen, Daniel, 214-15

musical allusion using well-known songs

"The Girl I Left Behind", 52-53

"Hail to the Chief," 52, 88, 96-97

"Hot Time in the Old Town Tonight," 57, 71

music in political ads

argument for removing from negative ads, 220

avoiding as distraction from message, $88-89$

Bush 41 campaign's skillful use of, 127-28

catchy tune vs. economics lecture, $47-48$

Clinton's refraining from in certain ads, 134

dichotomies created by, 40

function of, 24-30

ineffability of music in political debate, 
loss of ad effectiveness from lack of, 83,135 media commentary on (2012), 187 metadiscursive function of, $84,173-74$ "Morning in America" as sophisticated exemplar of, 102

persuasive effectiveness of, 27, 173, 212, 218-19

proposal for critical thinking education on, 220-21

relationship to verbal dimension, 108

as rhetorical device, 112

and rise of style over substance in advertising, $105^{-6}$

scholarly marginalization of study on, 23-24

silence, role in musical narrative, $57-58,60$, $65,15^{2} \mathrm{n}_{3}$

as unifying force for entire campaign, 97, $99,117-18$

and value of democratic process, 205-6, 216

Wag the Dog as illustration, 212-13

See also emotional appeal of music in political ads; specific musical styles and terms

music literacy, public lack of, 220 musique concrète, "Harbor" (Bush) (1988), 123

Muskie, Edwin, 96

"My Job" (Obama) (2012), 193-94

Nader, Ralph, 144-45

negative ads

evoking primal emotions in, $16-18$

"Harbor" (Bush-Quayle) (1988), 119, 123

Nixon vs. Humphrey (1968), 63-72

Obama's need for in 2012, 186

plethora of in 1988, 95, 119

proposals for improving quality of, 220

"Russian Bear" (Reagan) (1984), 110-12

"Scary" (Clinton) (1992), 134

series of Trump's, $195^{-96}$

virtue or vice of, $16-17$

"Young Vets" (McGovern) (1972), 88-89

See also attack ads

Negro spiritual, and "I Like Ike," 38

neotonal background music, 115, 134-35

neuromarketing, 214-15

New Frontier (Kennedy vs. Nixon 1960), 54

"news music" to create urgency, 181

Nicholl, Matthew, 241-51

Nixon, Richard, 50, 71, 73. See also Kennedy vs. Nixon

Nixon-Agnew Victory Committee, 64-65

"Nixon Now" (Nixon-Agnew) (1972), 74-80

"Nixon's Experience" (Kennedy-Johnson) (1968), 5on 5

"Nixon the Man" (Nixon) (1972), 84-87

Nixon vs. Humphrey (1968), 63-72

"Bomb" (Humphrey), 69

"Convention" (Nixon), 26, 70-72
"The First Civil Right" (Nixon), 26, 64-65

"Mother and Child" (Humphrey), 65-69

Nixon vs. McGovern (1972), 73-89

"McGovern Defense" (Democrats for Nixon), 26, 87-88, 117

"Nixon Now" (Nixon), 74-80

"Nixon the Man" (Nixon), 84-87

"Russia" (Nixon), 80-82

"Russian Response" (McGovern), 83

"Young Vets" (McGovern), 88-89

"No Maverick" (Obama) (2008), 182-84

nonverbal emotional appeals in ads,

persuasiveness of, 22-23. See also emotional

appeal of music in political ads

nostalgic appeals from Sanders and Trump,

210-11

The November 5 Group, 142-43

The November Company, 130-34

The November Group, 74-87

Obama, Barack, 175, 184, 185, 186, 199, 204

Obama-Biden, "Yes, We Can" (Obama-Biden)

(2008), 176-77

Obama for America 2008, 180-84

Obama for America 2012, 186, 187-94

Obama Media Team, $180-84$

Obama vs. McCain (2008), 175-84

"Celeb" (McCain), 178-80

"Dr. No" (McCain), 177-78

"Embrace" (Obama), 181-82

"Fundamentals" (Obama), 180-81

"Not Maverick" (Obama), 182-84

"Yes, We Can" (Obama), 176-77

Obama vs. Romney (2012), 185-94

"Big Bird" (Obama), 190-92

"Firms" (Obama), 186, 187-89

"Mandatory" (Obama), 189-9o

"My Job" (Obama), 193-94

"Political Payoffs and Middle Class Layoffs" (Romney), 186, 192

"These Hands" (Romney) (2012), 186

online political advertising, 30, 145, 177-78

orchestral hymn (Reagan 1980), 96-97

orchestrating public opinion

conclusion, 212-21

cultural artifacts of, $18-20$

defining influence of orchestration in ads, 13-14

how music functions in ads, $24-30$

ineffability of music, $20-21$

negative ads, $16-18$

scholarship review, 23-24

as voter persuasion, $21-23$

See also music in political ads

Orientalist music, 141, 197-98

ostinato tonal motive

"Dangerous World" (Bush) (200o), 148-50

"Ike for President" (Eisenhower) (1952), 35,37 
"Limo" (Mondale) (1984), 114

"Mandatory" (Obama) (2012), 190

"Outsourcing" (Trump) (2016), 195-98

"Oval Office" (Dukakis-Bentsen) (1988), 126

Packard, Vance, 52, 217, 218

Page, Benjamin I., 204

pandiatonicism, 111

pathos. See emotional appeal of music in political ads

Patterson, Jim, 132

Pavlov, Ivan, 14, 16

"Peace" (Ford) (1976), 91-92

"Peace" (Reagan) (1980), 96-97, 110

Penn, Mark, 18

pentatonic melody, singability of, 76

percussion

in contrast ad, 141-42

and sense of chaos, 65

See also drum effects

percussive march cadences, 87,88

Perot, Ross, 129

persuading voters

fear-based messages for fostering action,

$$
11-12,15^{-16,26}
$$

lack of scholarly attention to music's role in,

$$
\text { 27, 218-19 }
$$

nonverbal media's role in, $215^{-17}$

orchestrating public opinion's role in,

$$
\text { 21-23 }
$$

timing of ads for maximum effect, 21-22

plagal cadences, and sense of finality and inevitability, 77

Podesta, Anthony, 125-26

political ads

influence in close elections (2004), 10

lack of accurate information in, 220

political advocacy groups, 10, 87-88, 169-70

"Political Payoffs and Middle Class Layoffs"

(Romney) (2012), 186, 192

pop music themes for candidates, 207-8

positive ads

"America" (Sanders) (2016), 207-11

"I Like Ike" (Eisenhower) (1952), 32-38

"I Love the Gov'" (Stevenson) (1952), 38-40

"Kennedy: Jingle" (1960), 47-53

maximum effect in 1984, 95

"Nixon the Man" (1972), 84-87

"Russia" (Nixon) (1972), 80-82

"State" (Carter) (1980), 98-100

See also advocacy ads

"Poverty" (Johnson) (1964), 58-59

The Powers of Horror (Kristeva), 123

"Predators" (Trump) (2016), 196

President Ford Committee 1976, 91-92

Press, Bill, 179

Prince of Denmark's March (Clarke), 85

Progress for America Voter Fund, 167-69

progressives exit from Democratic Party, 205

Sanders's development of, 207, 208-9

"Prouder, Stronger, Better" (Reagan-Bush)

(1984). See "Morning in America"

Quayle, J. Danforth, 126

racism in Bush-Quayle ' 88 ads, 120

radio mystery drama organ music, 44

Rafshoon, Gerald, 92-94

Rafshoon Communications, 97-98

rational vs. emotional motives for action

emotional appeal as superior to rational appeal in ads, $17,71,83$

and failure of "Furlough from the Truth"

(Dukakis) (1988), 125-26

and function of political ads, 22-23

mutual exclusivity of use in brain, 16

and "Scary" (Clinton) (1992), 134

Reagan, Ronald, 90, 95, 100

Reagan-Bush '84, 109-12

"Reagan's Record" (1980), 97

Reagan vs. Carter (1980), 95-100

"Commander" (Carter), 97-98

"Liberty Park/Hope Campaign 80" (Reagan), 97

"Peace" (Reagan), 96-97

"State" (Carter), 98-100

Reagan vs. Mondale (1984), 101-18

"Failure 3" (Mondale), 116-18

"Limo" (Mondale), 113-14

"Loopholes" (Mondale), 115

"Morning in America," 101-9

"Russian Bear" (Reagan), 110-12

"Train" (Reagan), 109-10

"World Leaders" (Reagan-Bush) (1984), 110

Rebuilding America Now, 195-98

Reeves, Rosser, 31, 74

Reform Party (1992), 134-35

Reid, Harry, 200

Republican National Committee

"Education Recession" (Bush) (2000), 145

"Morality" (Goldwater) (1964), 59-62

Republican Party

particular creativity of ads in 2004, 166

as "Party of No" vs. "Dr. No" ad, 178

primary battle in 2016,198

and Roger Ailes, 104-5

response ads

"Counterpunch" (Dukakis) (1988), 127-28

"Embrace" (Obama) (2008), 181-82

"I Love the Gov"” (Stevenson) (1952), 38-40

"Russia Response" (McGovern) (1972), 83

The Responsive Chord (Schwartz), 215

"Revolving Door" (Bush-Quayle) (1988), 105n7, $119,120-22$

rhetorical techniques in political ads

Eisenhower vs. Stevenson era (1952), 31

"Guess" (Bush) (1992), 131-32 
vs. musical appeals, 20, 164-65

music as separate element in, $56,60-61$, $63-72,70-72$

music's role in psychological preparation for war, 213-14

Obama's rhetorical style, 177

"Russian Bear" (Reagan) (1984), 111-12

"Wacky" (Bush) (2004), 170-72

"Wolves" (Bush) (2004), 153-57, 164

See also enthymemes

Ridout, Travis N., 22

Riney, Hal, 105, 108, 110-12

Rodman, Ron, 18-19, 187

Rogich, Sig, 104

"Role Models" (Clinton) (2012), 196

Romney, Mitt, 185. See also Obama vs. Romney

Roosevelt, Franklin Delano, 53, 58

Roseboom, Eugene H., 94

Rousseau, Jean-Jacques, 221

"Russian Bear" (Reagan-Bush) (1984), 104n6, $110-12$

"Russia" (Nixon-Agnew) (1972), 80-82

"Russia Response" (McGovern) (1972), 83

Rutherford, John, 66

Sampietro, Anselmo, 203

Sanders, Bernie, 198-201, 203-5, 206-11

satire in political ads, 191

"Scary" (Clinton-Gore) (1992), 134

Scheuren, Fritz, 203

Schoening, Benjamin, 26-27

Schwartz, Tony, 56n1, 62, 65-69, 83, 215

Scott, Ridley, 109

Seducing America: How Television Charms the

Modern Voter (Hart), 19-20, 23-24

"Sellout" (Swift Boat) (2004), 169-70

Shakespeare, Frank, $64-65,70-72$

Sherr, Susan, $17-18$

silence vs. music, role in ad narrative, $57-58$, $60,65,15^{2 n} 3$

Simon: A Life (Eliot), 207

Simon and Garfunkel, 207, 208-9, 210

singability of "Nixon Now," 76-77

singing by candidates in political ads, 186,188 , 192

Smith, Paul, 34

socialism, stigma of for Americans, 130n1, 131

"soft sell" approach to advertising, 74

sonorous envelope of political ad, 18

"South" (Carter) (1976), 92-94

Southern voters, $5^{1-} \mathbf{5}^{2}, 59$

Soviet Union, Nixon's humanizing of, $81-82$

spaghetti Western film music, $182-83$

Sparkman, John, 37

spending on political ads, 29-30

Stanley, Timothy, 96

"State" (Carter-Mondale) (1980), 98-100

stereophonic sound, first use of, 101-9

Stevens, Reed, Curcio and Potholm, $169-70$
Stevenson, Adlai, 37, 42, 45, 46, 75. See also

Eisenhower vs. Stevenson

Stockwell, Dean, 37

Strauss, Johann II, 19, 173

"Stripes" (Dole-Kemp) (1996), 139-40

subliminal/surreptitious advertising

1984 campaign's mastery of, 117

in "Commander" (Carter) (1980), 97-98

"Morning in America" as, 104

musical allusions, 52-53, 71, 88, 96-97

"Surgeon" (Clinton-Gore) (1996), 142-43

Swan Lake (Tchaikovsky), 81

Swift Boat Veterans for Truth 2004, 169-70

swing voters, potential of music in ads in influencing, 22-23

“Tank Ride” (Bush-Quayle) (1988), 119, 124-25

"Taxi Drive and Dog" (Eisenhower) (1956), $43-46$

Taylor, Timothy, 78

Tchaikovsky, Piotr, 81

Teeter, Robert, 94

television ads

influence of, $22-23$

relevance compared to internet, $215^{-16}$

See also music in political ads

television debates, Kennedy-Nixon (1968), 49

terrorism as W. Bush theme (2004), 11, 151-52, 159nn17-18, 166-69

"Testing Theories of American Politics" (Gilens and Page), 204

"These Hands" (Romney) (2012), 186

"They [I] Like Ike" (Berlin), 45

"third-person effect," 19

"The Threat" (Dole-Kemp) (1996), 140-41

timbre of music, 139n1

time frame for political ads, shrinking of, 102

"Train" (Reagan-Bush) (1984), 109-10, 118

Treleaven, Harry, 64-65, 70-72

Truman, Harry, 37

Trump, Donald J., 196, 198, 210

Trump vs. Clinton (2016), 195-211

"America" (Sanders), 206-11

Democratic split (Sanders vs. Clinton), 198-206

"Outsourcing” (Trump), 195-98

"Unfit" (Trump), 196

Tuesday Team, 95, 101-12, 117

underscoring in "Wolves" (Bush) (2004), 162

"Unfit" (Trump) (2016), 196

vococentrism, 68

voice-over

disembodied female narrator, 130-31, 158-59

female for fear in "Wolves," 11

male narrator in "Mother and Child," 68 parody of voice-over artist in "Big Bird," 191 
synchronizing with mood of music in "Wolves," 12 voter preferences and turnout, influence of political ads on, 19-20, 22-23 voters, 1950 s ads' treatment of, 31. See also persuading voters

voter suppression, 10n1, 199

"Voting Booth" (Johnson) (1964), 57-58

voting machine software, 203

"Wacky" (Bush-Cheney) (2004), 170-72 Wag the Dog (film, Levinson), 212-13

Waldman, Paul, 17-18

Wallace, George, 59

waltz time, 19, 173

War on Poverty, 59

Washburn, C. Langhorne, 42

Wasserman Schultz, Debbie, 199, 200

Watergate, impact on Ford's campaign, 91-92 web ads, $30,145,177-78$

"We Like Ike" cartoon, 33-38

Weller, James, 131-34

West, Darrell M., 150

"Whatever It Takes" (Bush-Cheney) (2004), 166-67

"Who We Are" (Clinton) (2012), 196

will.i.am, 176-77

"Willie Horton" (Bush-Quayle) (1988), 119, 120

"Windsurfing" (Bush-Cheney) (2004), 19, 172-74

"Wolves" (Bush-Cheney) (2004), 10-12, 26, 27, $110,151-65$

words spoken by candidates, using against them in ads, $185^{-95}$

"World Leaders" (Reagan-Bush) (1984), 110

"Yes, We Can" (Obama-Biden) (2008), 176-77

Young and Rubicon, 43-46

"Young Vets" (McGovern) (1972), 88-89 